\title{
32. CENOZOIC RADIOLARIA FROM THE WESTERN TROPICAL PACIFIC, LEG 7
}

W. R. Riedel and Annika Sanfilippo, Scripps Institution of Oceanography, La Jolla, California

\section{CONTENTS}

$\begin{array}{ll}\text { 1. Introduction } & 1530\end{array}$

2. "Morphotypic" and "Evolutionary" Limits of Species (with Figure 1) 1530

3. Scope of Investigation and Presentation of Results 1530

4. Radiolarians at Each Site 1531

a. Site $61 \quad 1532$

b. Site 62 (with Table 1) 1532

c. Site 63 (with Table 2) 1532

d. Site 64 (with Table 3) 1532

e. Site 65 (with Table 4) 1533

f. Site 66 (with Table 5) 1533

g. Site $67 \quad 1533$

5. Time-ranges of Taxa, and Biostratigraphic Zonation (with Table 6 and Figure 2) 1545

6. Correlations with Europe and the Caribbean (with Figure 3) 1580

a. European Neogene (with Table 7) 1580

b. European Eocene 1582

c. Caribbean Neogene (with Table 8) 1583

d. Caribbean Eocene 1583

7. Some Comments on the Results 1585

a. Preservation of Radiolarians 1585

b. Paleoenvironmental interpretations 1585

c. Hiatuses in sedimentation $\quad 1585$

d. New Information on Phylogeny 1586

8. Systematic Section 1586

a. Collosphaeridae 1586

b. Actinommidae 1587

$\begin{array}{ll}\text { c. Coccodiscidae } & 1588\end{array}$

d. Spongodiscidae 1588

e. Acanthodesmiidae 1590

f. Theoperidae 1592

g. Carpocaniidae 1596

h. Pterocoryidae 1598

i. Artostrobiidae 1599

$\begin{array}{ll}\text { j. Cannobotryidae } & 1601\end{array}$

9. References 1603

10. Acknowledgements 1604

11. Plates - comprising synchronoption (Plates 1A-3F) and other plates (Plates 4-8) 1606

12. Index of Radiolarian Names 1668 


\section{INTRODUCTION}

All of the drilling-sites of Leg 7 of the Deep-Sea Drilling expedition yielded radiolarians. Their localities are the following:

Site $61 ; 12^{\circ} 05.8^{\prime} \mathrm{N}, 147^{\circ} 03.9^{\prime} \mathrm{E}$; water depth 5562 meters.

Site $62 ; 1^{\circ} 52.2^{\prime} \mathrm{N}, 141^{\circ} 56.3^{\prime} \mathrm{E}$; water depth 2591 meters.

Site $63 ; 0^{\circ} 50.16^{\prime} \mathrm{N}, 147^{\circ} 53.25^{\prime} \mathrm{E}$; water depth 4472 meters.

Site $64 ; 1^{\circ} 44.5^{\prime} \mathrm{N}, 158^{\circ} 36.51^{\prime} \mathrm{E}$; water depth 2052 meters.

Site $65 ; 4^{\circ} 21.21^{\prime} \mathrm{N}, 176^{\circ} 59.16^{\prime} \mathrm{E}$; water depth 6130 meters.

Site $66 ; 2^{\circ} 23.63^{\prime} \mathrm{N}, 166^{\circ} 07.28^{\prime} \mathrm{W}$; water depth 5293 meters.

Site $67 ; 24^{\circ} 22.52^{\prime} \mathrm{N}, 157^{\circ} 39.05^{\prime} \mathrm{W}$; water depth 4473 meters.

Cretaceous radiolarians (not included here because they are treated in a separate chapter by H. P. Foreman) were encountered at Sites 61 and 66, Upper Paleocene or Lower Eocene radiolarians at Site 67, Middle to Upper Eocene at Sites 64 and 65, Oligocene at Sites 64, 65 and possibly 66 , and Neogene at Sites 61 through 66. The Miocene parts of these sequences produced radiolarian results of the most fundamental significance -the continuously cored sequences provided a firmer basis for the zonation that had previously been based on scattered, short piston cores (Riedel and Sanfilippo, in press), and for correlation of the radiolarian zonation with the foraminiferal and calcareous nannofossil zonations. The Pliocene and Quaternary parts of the sequences were less satisfactory for these purposes because of the scarcity and poor preservation of radiolarians, and the older parts of the sequences were cored only intermittently.

Aboard the drilling vessel, samples for radiolarian investigation were taken at more or less fixed intervals in the cores. It soon became apparent that rates of accumulation at the different sites differed markedly, and that the samples were correspondingly unequally spaced through time. For this reason, some of the samples from the more rapidly accumulated sequences (at Sites 62 and 64, particularly) have not been investigated for this report.

Some of the samples prepared for radiolarian investigation yielded a sufficient number of skeletons to permit the separation of forms larger than 150 microns onto additional slides, after preparation of the regular slides bearing forms larger than 62 microns. These coarse preparations have proven especially useful for the investigation of some large and rare forms of considerable taxonomic and stratigraphic significance.

\section{2. "MORPHOTYPIC" AND "EVOLUTIONARY" LIMITS OF SPECIES}

In the course of an investigation such as that reported here, it is possible to define the limits of species in two fundamentally different ways, which we shall term "morphotypic" and "evolutionary". Morphotypic limits must be used when the evolutionary development of a species is not known, whereas when the phylogeny is known evolutionary limits may be applied.

To explain the difference between these two types of limits, Figure 1 illustrates the situation faced by a paleontologist who wishes to divide a series of continuously evolving forms $(A \rightarrow B \rightarrow C \rightarrow D \rightarrow E)$ into five species. In the tabulation of these successively younger forms in a series of successively younger assemblages, $\mathrm{C}$ indicates "common", F "few" and R "rare". The evolutionary change from A to E is clearly indicated by the drift of the C's across the tabulation from lower left to upper right. Morphological characters change continuously with time, and intraspecific variation is such that the dominant form in any assemblage is accompanied by fewer specimens morphologically identical with its ancestor(s) and descendant(s). The ranges of the morphotypes are long, and overlap one another to a considerable extent.

It would be possible to define the five morphotypes as separate species, but it seems more "biologically correct" to classify each population rather than each specimen, and to define the species in such a way that their ranges are contiguous but not overlapping. This requires a statistical definition of the range of variation of the morphological characters, and the resulting limits of the time-ranges of species are of the type here termed "evolutionary". In those cases in which we have plotted the upper or lower limit of a species as "evolutionary" (such as in Figure 1, Table 6 and Figure 2), we have used the level at which more than half of the individuals in the population have the character(s) that distinguishes the species from its ancestor or descendant.

\section{SCOPE OF INVESTIGATION AND PRESENTATION OF RESULTS}

In addition to our primary objective of determining the occurrences of forms previously known to be stratigraphically useful, we have also made a general survey of some families and selected some species for additional investigation. Simultaneously with determining the ranges of stratigraphically useful forms, a type of illustrated history of a larger number of late Eocene to Quaternary radiolarians has been produced, and is presented in Plates 1 through 3 as a synchronopticon. The arrangement of the illustrations in the synchronopticon is such that by scanning the plates horizontally an impression can be gained of the prominent forms in assemblages of a given age, and changes in a group 


\begin{tabular}{|c|c|c|c|c|c|c|c|c|c|}
\hline & & \multicolumn{5}{|c|}{ Successively younger forms } & \multirow{2}{*}{\multicolumn{2}{|c|}{$\begin{array}{l}\text { Morphotype } \\
\text { Ranges }\end{array}$}} & \multirow{2}{*}{$\begin{array}{c}\text { Evolutionary } \\
\text { Ranges }\end{array}$} \\
\hline & & A & B & C & D & E & & & \\
\hline \multirow{11}{*}{ 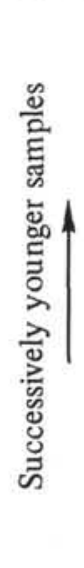 } & Spl. 11 & & & & $\mathrm{R}$ & C & \multirow{6}{*}{$\mathrm{T}$} & \multirow[b]{4}{*}{ E } & \\
\hline & Spl. 10 & & & $\mathrm{R}$ & F & C & & & 1 \\
\hline & Spl. 9 & & & $\mathrm{R}$ & C & F & & & \\
\hline & Spl. 8 & & & $\mathrm{~F}$ & $\mathrm{C}$ & F & & & D \\
\hline & Spl. 7 & & $\mathrm{R}$ & $\mathrm{F}$ & C & $\mathrm{R}$ & & & I \\
\hline & Spl. 6 & & $\mathrm{R}$ & $\mathrm{C}$ & F & R & & & 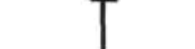 \\
\hline & Spl. 5 & & $\mathrm{R}$ & $\mathrm{C}$ & $\mathrm{F}$ & $\mathrm{R}$ & & & C \\
\hline & Spl. 4 & $\mathrm{R}$ & F & $\mathrm{C}$ & $\mathrm{R}$ & & B & & $\perp$ \\
\hline & Spl. 3 & $\mathrm{R}$ & $\mathrm{C}$ & $\mathrm{F}$ & $\mathrm{R}$ & & & & T \\
\hline & Spl. 2 & F & $\mathrm{C}$ & F & $\mathrm{R}$ & & A & & $\perp$ \\
\hline & Spl. 1 & C & F & $\mathrm{R}$ & & & & & \\
\hline
\end{tabular}

Figure 1. For explanation see text, Section 2.

through time are indicated vertically. Each horizontal row of illustrations is labeled to indicate the zone to which the assemblage belongs, but some zones are not represented because of the spacing of samples through the section.

The number of forms illustrated, or briefly mentioned in discussions, is much greater than the number that could be treated exhaustively in the time available for the preparation of this report. Consequently, there is a considerable range in the thoroughness with which the various taxa are treated. Some are merely mentioned in passing, and illustrated by one or a few figures in the synchronopticon, fewer have been investigated sufficiently to permit tabulation of their occurrences at each drilling site (Tables 1 through 5), and most but not all of these have their ranges plotted on a summary range-chart (Figure 2).

Table 6, in which the upper and lower limits of taxa are tabulated and which represents an intermediate step between Tables 1 through 5 and Figure 2, serves also to indicate levels of correlation between Sites 62 through 66. Since it is advantageous for some purposes to have taxa ordered systematically and for other purposes to have them ordered stratigraphically, a systematic arrangement of families (and an alphabetical arrangement within families) is used in Tables 1 through 5 , and a stratigraphic arrangement is used in Table 6 and Figure 2.

In these various presentations, we have made a distinction between "evolutionary" and "morphotypic" limits of species, as discussed in Section 2. In general, occurrences recorded on Tables 1 through 5 are on the basis of morphology alone, and their limits are thus "morphotypic", but on the range-chart we have attempted to define limits evolutionary wherever possible-" $m$ " is used to denote morphotypic limits, and " $\mathrm{e}$ " to denote evolutionary limits and extinctions.

In the tabulations we have abbreviated the names of certain taxa-their full and correct form is given in the Systematic Section.

\section{RADIOLARIANS AT EACH SITE}

In this section, the information on occurrences of radiolarians is tabulated for those sites at which significant sequences were recovered (Sites 62 through 66), and given in the text for those sites at which isolated samples were obtained (Sites 61 and 67). In the second column of Tables 1 through 5 , the abundance and preservation of radiolarians are indicated for each sample examined: the letters $\mathrm{A}, \mathrm{C}, \mathrm{F}$ and $\mathrm{R}$ indicate that radiolarians in the sample are abundant, common, few or rare, respectively; and G, M and P indicate that their preservation is good, moderate or poor, respectively. Preservation which is less than good is always the result of partial dissolution of the skeletons.

In the body of the tables, the letters A, C, F and R indicate the abundance of each species, and a dash is used to indicate absence of a species from a sample in which it was searched for. A positive (+) sign is used to indicate that one or two specimens were found on a single strewn-slide, and an " $R$ " is used when from three to about five specimens were found. " $\mathrm{A}$ " is used only for exceptionally abundant occurrences, "C" for common occurrences, and " $F$ " for few specimens (intermediate between $\mathrm{C}$ and $\mathrm{R}$ ). 


\section{4a. Site 61}

In addition to the Cretaceous radiolarians at this site described in the chapter by H. P. Foreman, the sample from a depth of about 80 meters (61.0-1-CC) contains a well-preserved, diverse assemblage assignable to the Calocycletta costata Zone, including Cannartus mammiferus (rare), C. violina (rare), Dorcadospyris dentata (rare), Cyclampterium leptetrum (rare), Cyrtocapsella cornuta (few), Lithopera renzae (rare), Stichocorys armata (rare), S. diploconus (rare), $S$. wolffii (common), Carpocanopsis bramlettei (rare), C. cingulatum (rare), C. favosum (rare), Calocycletta costata (few), C. virginis (few) and Phormostichoartus corona (rare). No Eocene or Oligocene forms were found admixed in this sample.

\section{4b. Site 62 (with Table 1)}

Radiolarians are generally scarce and rather poorly preserved in the upper 200 meters of the section (down to 62.1-21), more common and better preserved to about 350 meters (62.1-37), then again rare and poorly preserved at about 355 meters (62.1-38), absent at about 360 meters (62.1-39), common and moderately well-preserved at about 400 meters and 495 meters (62.0-4 and 62.0-5), and absent in deeper samples.

Within the upper 200 meters, the only zonal boundary that can be recognized, indistinctly, is the base of the Spongaster pentas Zone at about 123 to 126 meters (between 62.1-13-3 and 63.1-13-5). The base of the Stichocorys peregrina Zone is at 202 to 204 meters (between 62.1-21-5 and 62.1-21-CC); the base of the Ommatartus penultimus Zone is at 225 to 227 meters (between 62.1-23-CC and 62.1-24-2); the base of the Ommatartus antepenultimus Zone is at 290 to 298 meters (between 62.1-30-CC and 62.1-31-5); the base of the Cannartus (?) petterssoni Zone is at 329 to 334 meters (between 62.1-35-2 and 62.1-35-5); the base of the Dorcadospyris alata Zone is at 350 to 396 meters (between 62.1-37 and 62.0-4); the base of the Calocycletta costata Zone is at 404 to 492 meters (between 62.0-4-CC and 62.0-5-2); and the base of the Calocycletta virginis Zone is below 499 meters (below 62.0-5-CC).

No reworked older radiolarians were found in any samples from this site.

\section{4c. Site 63 (with Table 2)}

Radiolarians are only moderately common, and sometimes poorly preserved, in the continuously cored section from the sea floor to 41 meters $(63.0-1,63.1-1$ to $63.1-4$, and $63.2-1$ to $63.2-3)$. From 62 to 361 meters (63.0-2 to $63.0-5$, and $63.1-5$ to $63.1-14$ ) they are common to abundant, and generally well-preserved; none are present in the deeper samples.
Recognition of radiolarian zones in the upper part of the section is difficult, but it appears that the top of the Pterocanium prismatium Zone may be at about 4 to 7 meters (between 63.1-1-1 and 63.1-1-3); the base of the $P$. prismatium Zone may be at about 22 to 23 meters (between 63.1-2-CC and 63.1-3-1); the base of the Spongaster pentas Zone is at 31 to 35 meters (between 63.2-3-1 and 63.2-3-4); and, the base of the Stichocorys peregrina Zone is at 39 to 63 meters (between 63.2-3-CC and 63.0-2-2). Older zonal boundaries can be recognized more confidently: the base of the Ommatartus penultimus Zone is at 66 to 69 meters (between 63.0-2-4 and 63.0-2-6); the base of the Ommatartus antepenultimus Zone is at 102 to 105 meters (between 63.1-5-1 and 63.1-5-3); the base of the Cannartus (?) petterssoni Zone is at 131 to 134 meters (between 63.1-8-2 and 63.1-8-4); the base of the Dorcadospyris alata Zone is at 149 to 152 meters (between 63.1-10-1 and 63.1-10-3); the base of the Calocycletta costata Zone is at 183 to 185 meters (between 63.1-13-CC and 63.1-14-1); and, the base of the Calocycletta virginis Zone and the entire Lychnocanium bipes Zone are in the interval 239 to 353 meters (between 63.0-4 and 63.0-5). The lowest radiolarian core (63.0-5), at about 350 to 360 meters, is in the Dorcadospyris ateuchus Zone.

Practically no reworked older radiolarians were observed in the samples examined from this site.

\section{4d. Site 64 (with Table 3)}

Radiolarians are common and fairly well-preserved in all cores taken at this site, except in the bottom of the section (64.1-11) at about 980 meters below the sea floor, where they are altered and partly dissolved.

The assemblage in the surface core (64.0-1) is Quaternary; those at about 100 meters $(64.0-2)$ are in the Spongaster pentas Zone; those at about 205 meters (64.0-3) are in the Ommatartus antepenultimus Zone; those at about 305 meters (64.0-4) are in the Cannartus (?) petterssoni Zone; and those from about 410 to 437 meters (64.0-5 and upper part of 64.1-1) are in the Dorcadospyris alata Zone. The continuously cored section from 437 to 479 meters (lower part of 64.1-1 through 64.1-5) is in the Calocycletta costata Zone. The assemblages at about 510, 570 and 615 meters (64.0-6, 64.1-6 and 64.0-7) are in the Calocycletta virginis Zone; those at about 665 meters (64.1-7) are in the Lychnocanium bipes Zone; those at about 710,750 and 775 meters (64.0-8, 64.1-8 and 64.0-9) are in the Dorcadospyris ateuchus Zone; those at about 850 meters (upper part of 64.0-10) are in the Theocyrtis tuberosa Zone; those at about 851 and 915 meters (lower part of 64.0-10 and 64.1-9) are in the upper part of the Thyrsocyrtis bromia Zone; and those at about 970 and possibly 984 meters (64.1-10 and possibly 64.1-11) are in the Podocyrtis mitra Zone. 
There is probably a hiatus or a compressed section between 915 and 970 meters, because the 55 -meter interval between Cores 64.1-9 and 64.1-10 seems too short to accommodate the lower part of the Thyrsocyrtis bromia Zone, the Thyrsocyrtis tetracantha Zone and the Podocyrtis chalara Zone.

\section{4e. Site 65 (with Table 4)}

Radiolarians are abundant and well-preserved in all cores from the sea floor to a depth of about 168 meters (65.1-5), but reworked forms of ages back to Middle Eocene are common throughout and hamper interpretation of the sequence. The sample recovered at about 180 meters (65.1-7) was too small for radiolarian separation, and the sample at about 186 meters (65.1-8) contains rather few, poorly preserved radiolarians of approximately the same age as those in 65.1-5-CC. Lumps of semiconsolidated sediment at about 135 meters (65.1-1) contain rare, altered radiolarians of probably Cretaceous age.

Because of the ubiquitous reworking, interpretation of the sequence depends upon the lower limits only of the ranges of taxa, and some zonal boundaries are not clear. The base of the Spongaster pentas Zone is probably at 19 to 21 meters (between 65.0-2 and 65.0-3); the base of the Stichocorys peregrina Zone is at 42 to 45 meters (between 65.0-5-4 and 65.0-5-6); the base of the $\mathrm{Om}$ matartus antepenultimus Zone is at 57 to 60 meters (between 65.0-7-2 and 65.0-7-4; the base of the Cannartus (?) petterssoni Zone is at 60 to 68 meters (between 65.0-7-4 and 65.0-8-3); the base of the Calocycletta costata Zone is at 73 to 75 meters (between 65.0-8 and 65.0-9); the base of the Calocycletta virginis Zone is at 101 to 102 meters (between 65.0-11 and 65.0-12); the base of the Lychnocanium bipes Zone is at about 106 meters (within 65.0-12-4); the base of the Dorcadospyris ateuchus Zone is at 112 to 114 meters (between 65.0-13-2 and 65.0-13-3); the base of the Theocyrtis tuberosa Zone is at 126 to 128 meters (between $65.0-14-5$ and $65.0-14-\mathrm{CC}$ ); the base of the Thyrsocyrtis bromia Zone is at about 145 meters (between 65.1-2-1 and 65.0-16-CC); the base of the Thyrsocyrtis tetracantha Zone is at 145 to 154 meters (between 65.1-2-1 and 65.1-2-CC); and the base of the Podocyrtis chalara Zone is below about 168 meters (65.1-5-CC).

At this site, the Dorcadospyris alata Zone can be no more than 5 meters thick (between 65.0-7-4 and $65.0-8-1$, at 60 to 65 meters), and may be missing altogether, whereas at Site 62 it occupies at least 16 meters, and at both Site 63 and Site 66 it occupies approximately 20 meters.

\section{4f. Site 66 (with Table 5)}

Radiolarians are abundant in all cores to a depth of 126 meters below the sea floor (66.0-3), and are well preserved in all samples except those from the lower few meters which are somewhat corroded. Samples below this are barren of radiolarians to a depth of about 190 meters, where a Cretaceous assemblage was encountered in 66.0-9 (see chapter by H. P. Foreman in this volume).

The continuously cored section from about 16 to 88 meters below the sea floor (66.0-1 to 66.0-2 and 66.1-8) may represent a continuous section from early Quaternary to the upper part of the Calocycletta costata Zone. The base of the Quaternary is at 21 to 24 meters (between 66.1-2-1 and 66.1-2-3); the base of the Pterocanium prismatium Zone is at 24 to 27 meters (between 66.1-2-3 and 66.1-2-5); the base of the Spongaster pentas Zone is at 29 to 30 meters (between 66.1-2-CC and 66.1-3-1); the Stichocorys peregrina Zone is indistinct and apparently short at about 39 meters (bottom of 66.1-3-CC and/or top of 66.1-4-1); the base of the Ommatartus antepenultimus Zone is at 56 to 61 meters (between 66.1-5-CC and 66.1-6-4); the base of the Cannartus (?) petterssoni Zone is at 65 to 68 meters (between 66.1-6-CC and 66.1-7-1); and the base of the Dorcadospyris alata Zone is at 85 to 88 meters (between 66.1-8-CC and 66.0-2-CC). The base of the Calocycletta costata Zone is in the uncored interval between 88 and 118 meters (66.0-2-CC to 66.1-3-1), and the base of the Calocycletta virginis Zone is at about 121 to 122 meters (between 66.0-3-3 and 66.0-3-4).

There are a few reworked Miocene radiolarians at some levels in the Quaternary and late Miocene parts of the section, and Core 66.0-3 contains rare Eocene forms.

\section{4g. Site 67}

The only radiolarian found in the surface core (67.0-1) was a single specimen, apparently reworked, of the Lower to Middle Eocene form Thyrsocyrtis hirsuta hirsuta. Core 67.1-1, from about 23 meters, contains no radiolarians, but the sample from about 59 meters (67.1-2-CC) contains a sufficient number to permit an age determination.

In addition to the diverse, rather well-preserved Paleogene assemblage, the radiolarian preparations from 67.1-2-CC contain many well-formed, twinned zeolites and ferromanganese micronodules, and much fish skeletal debris. This association suggests an artificial admixture of a non-radiolarian zeolitic clay with a radiolarian ooze, which could be caused by caving from the sides of the drill-hole. A few well-preserved Quaternary radiolarians occur together with the Paleogene forms, but there appears to be no admixture of forms of intermediate age. Thus, the radiolarian assemblage in this sample may be used as an indication of the age of a level somewhere between Core 67.1-1 and 67.1-2-CC. 
岕

TABLE 1A

Radiolarians at Site 62

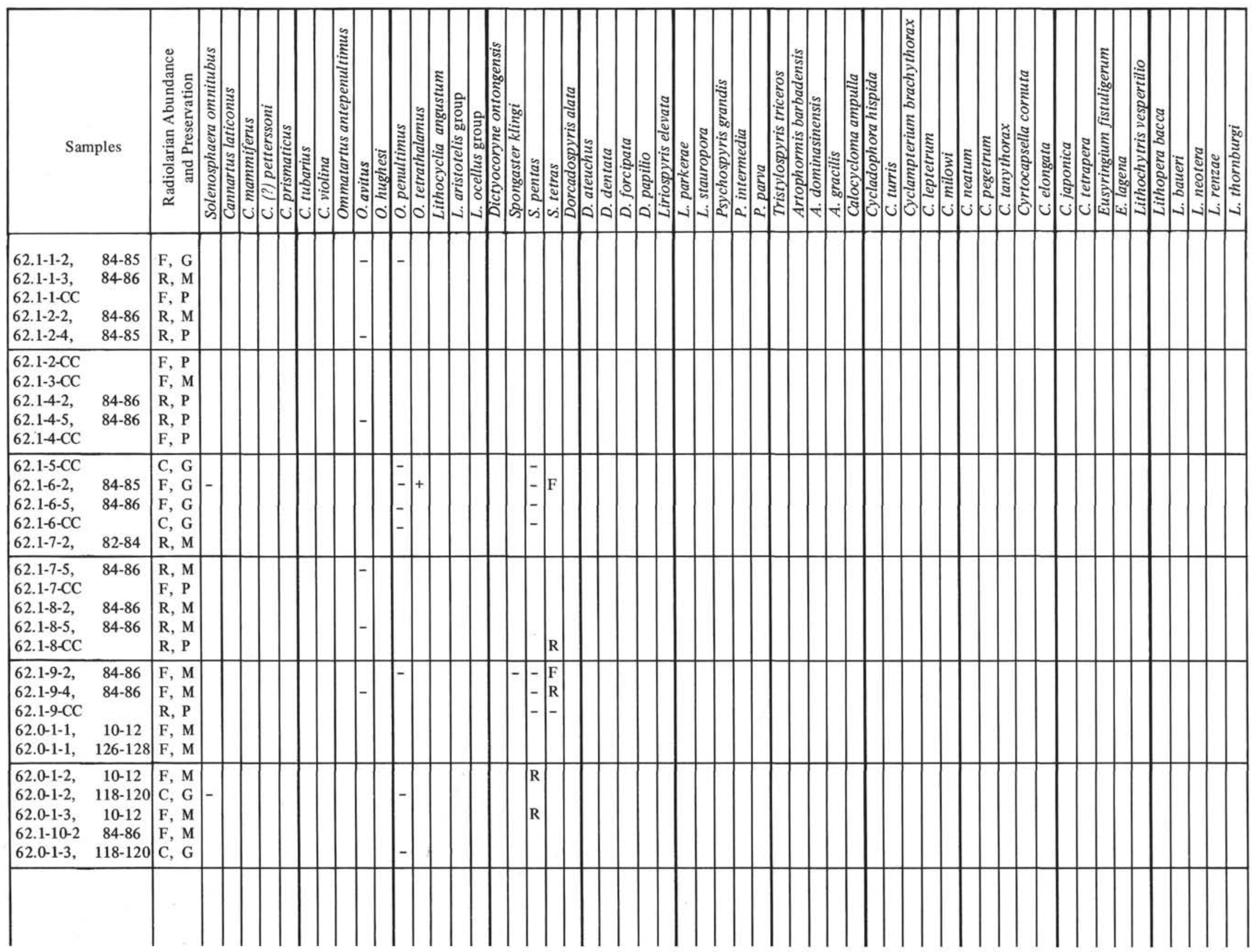




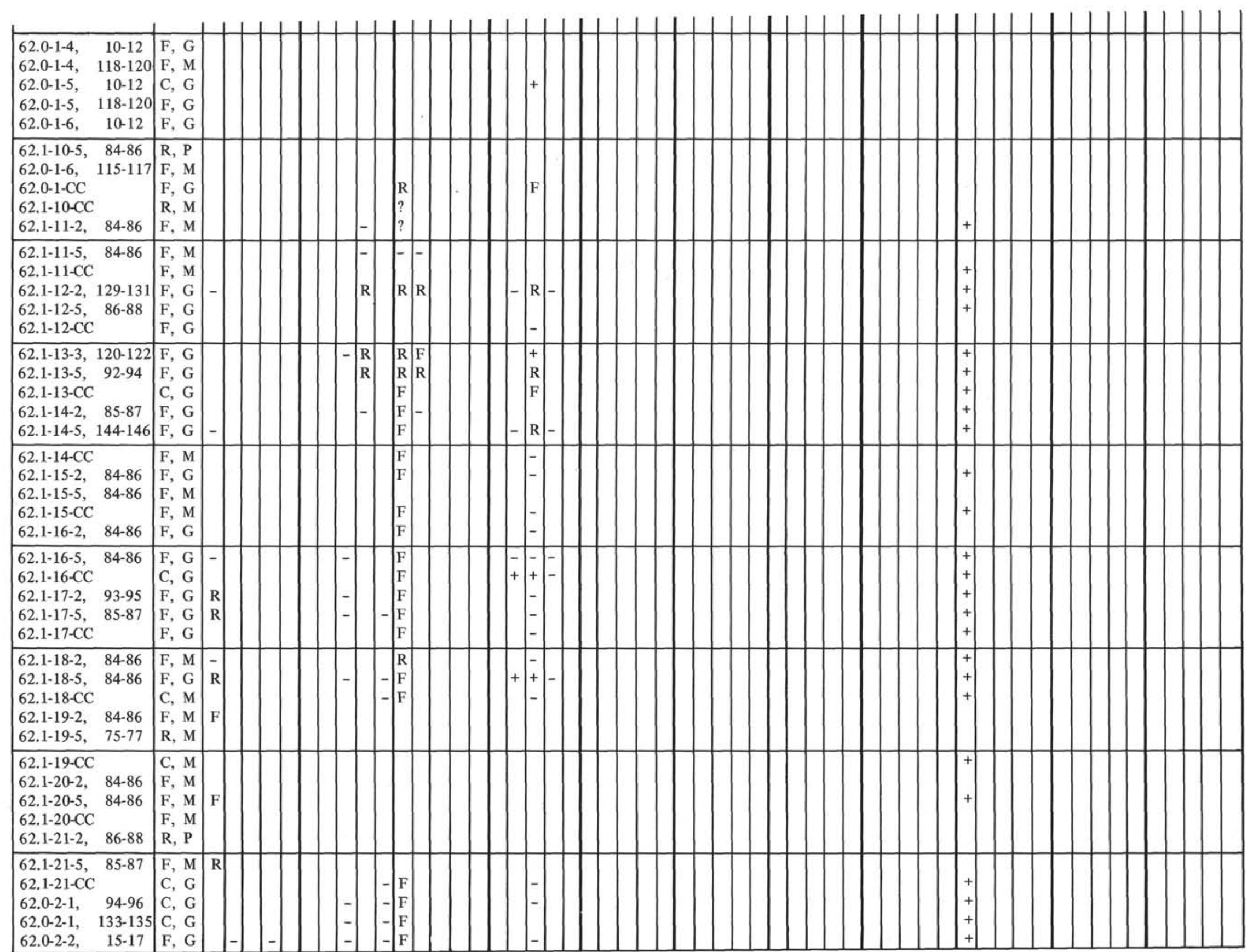


TABLE 1A - Continued

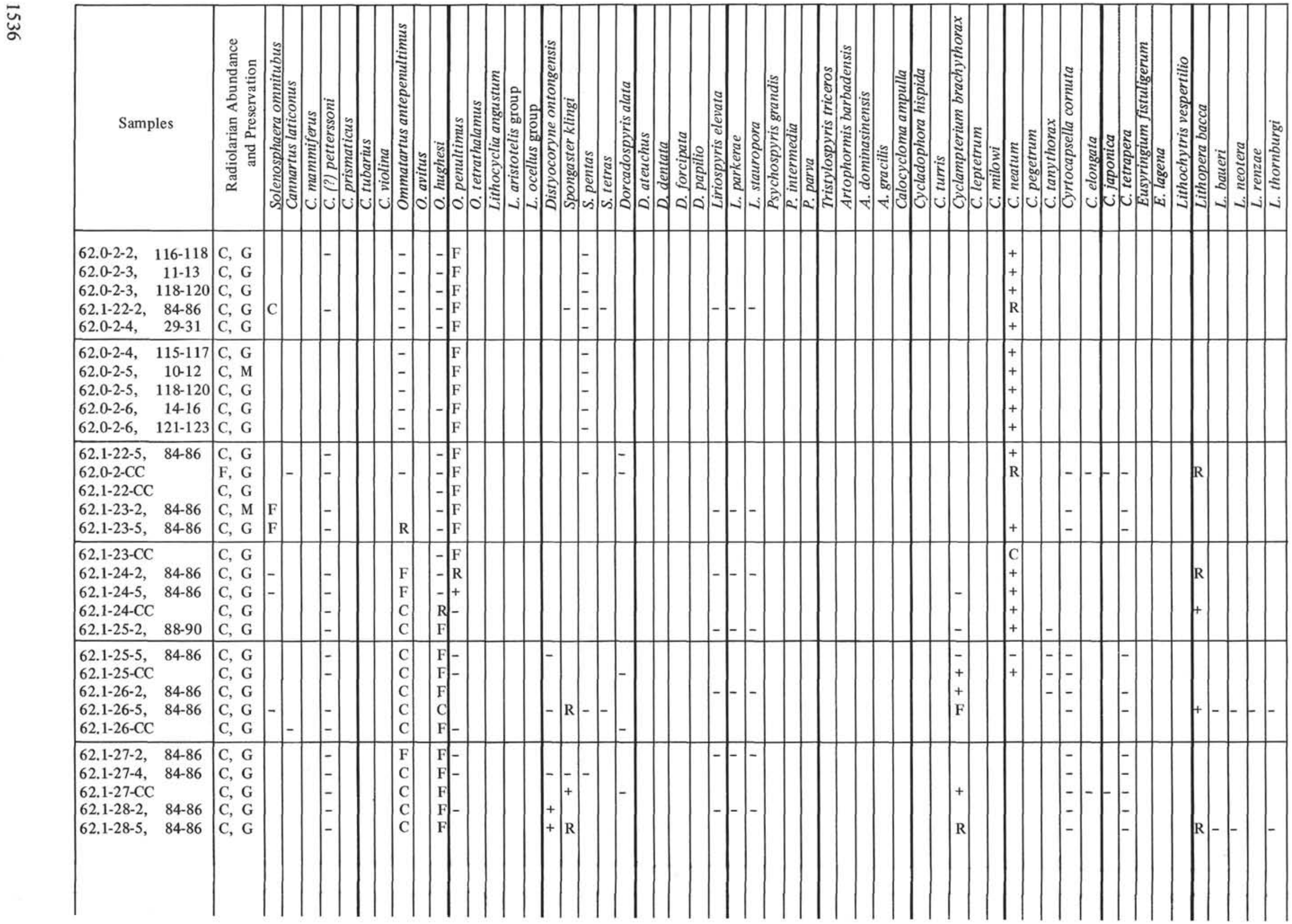


TABLE 1B

Radiolarians at Site 62

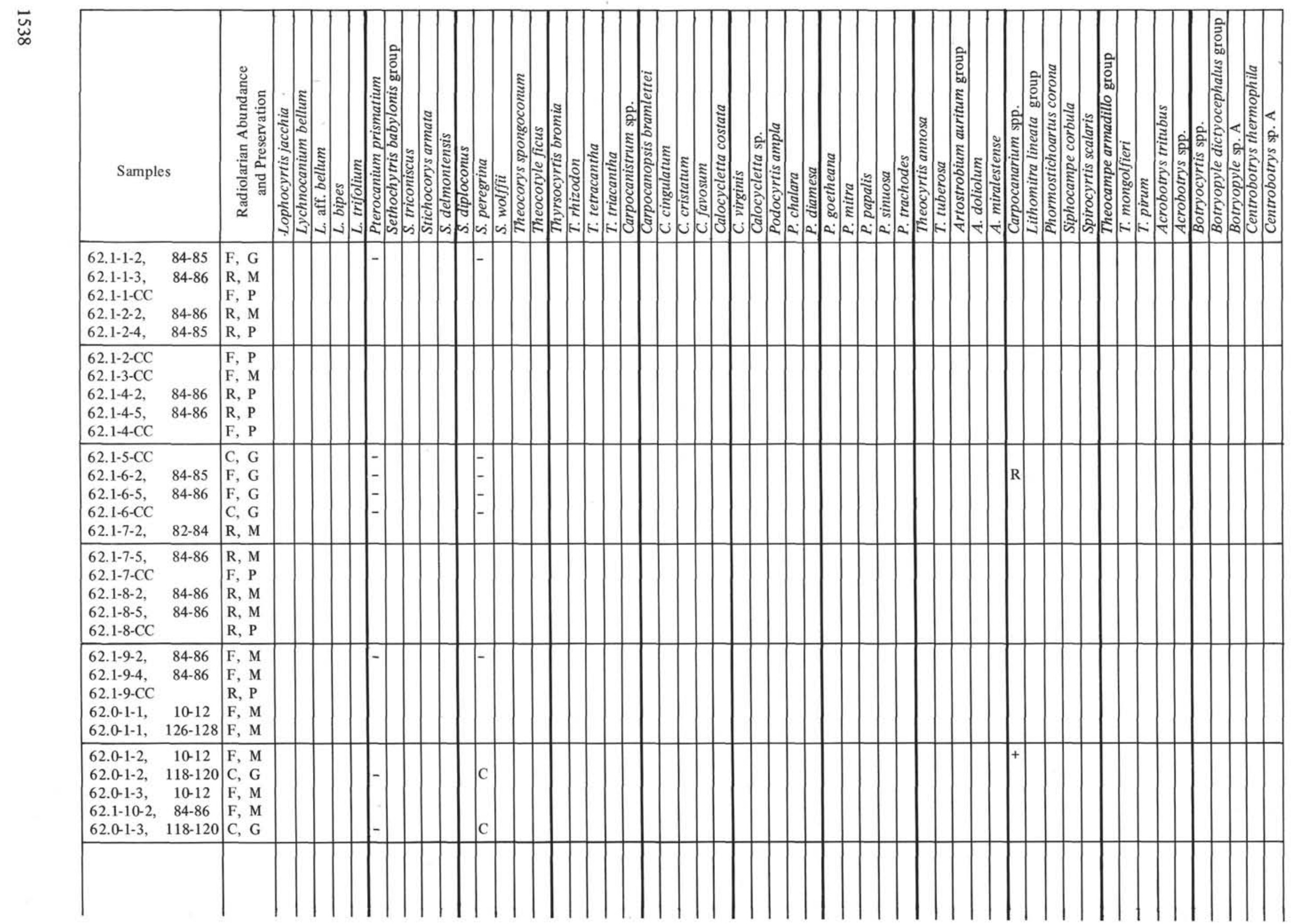




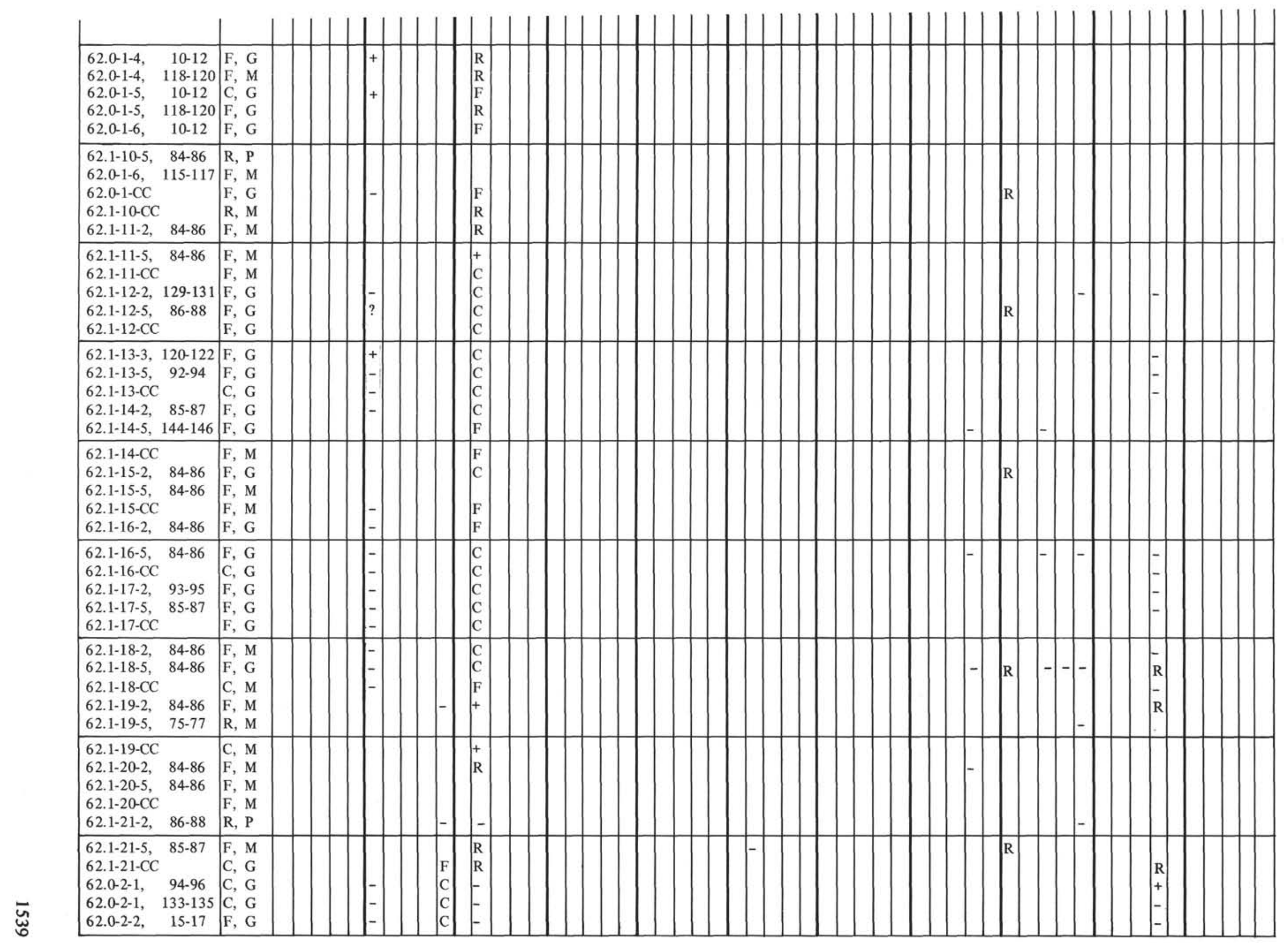




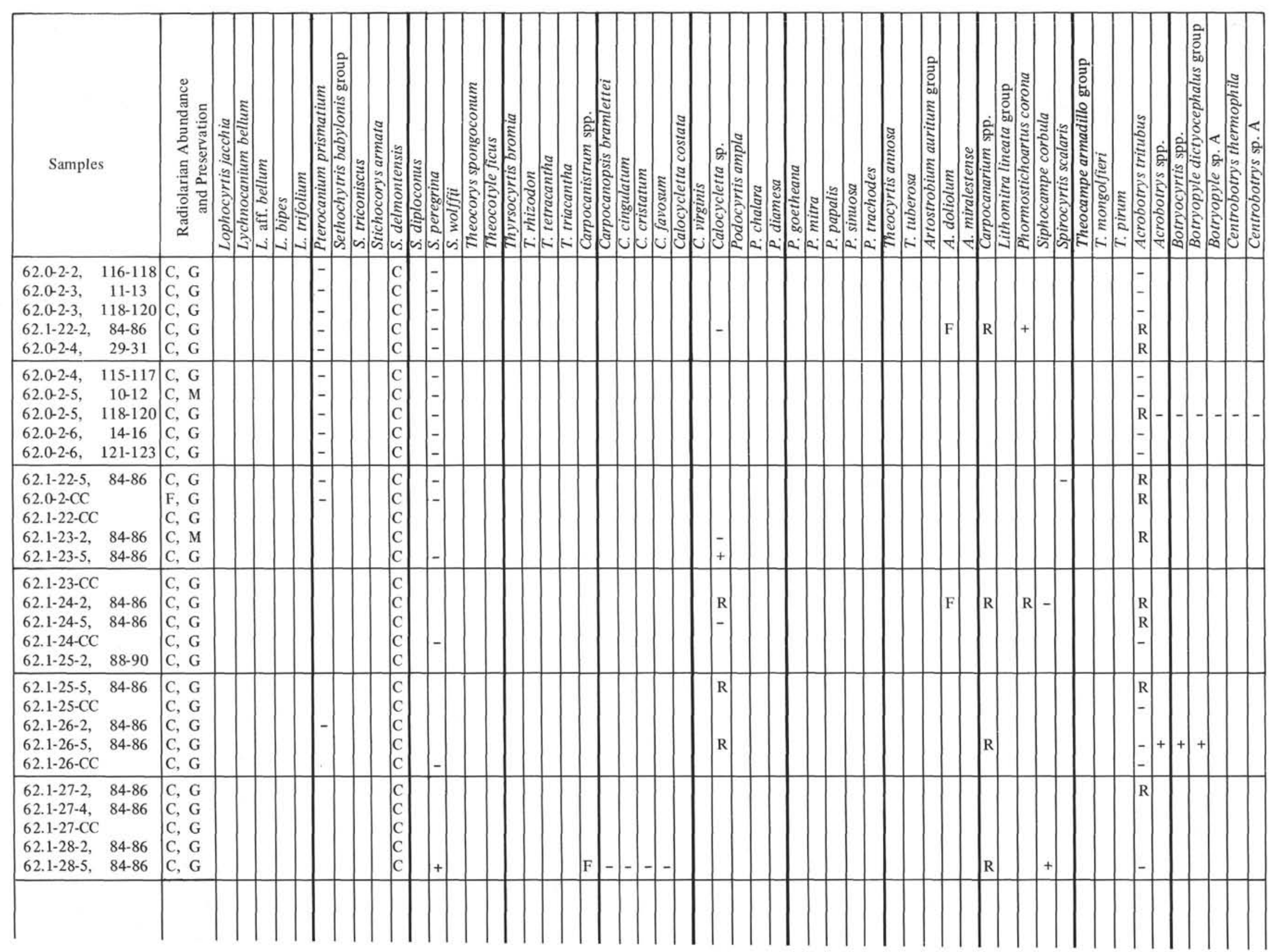




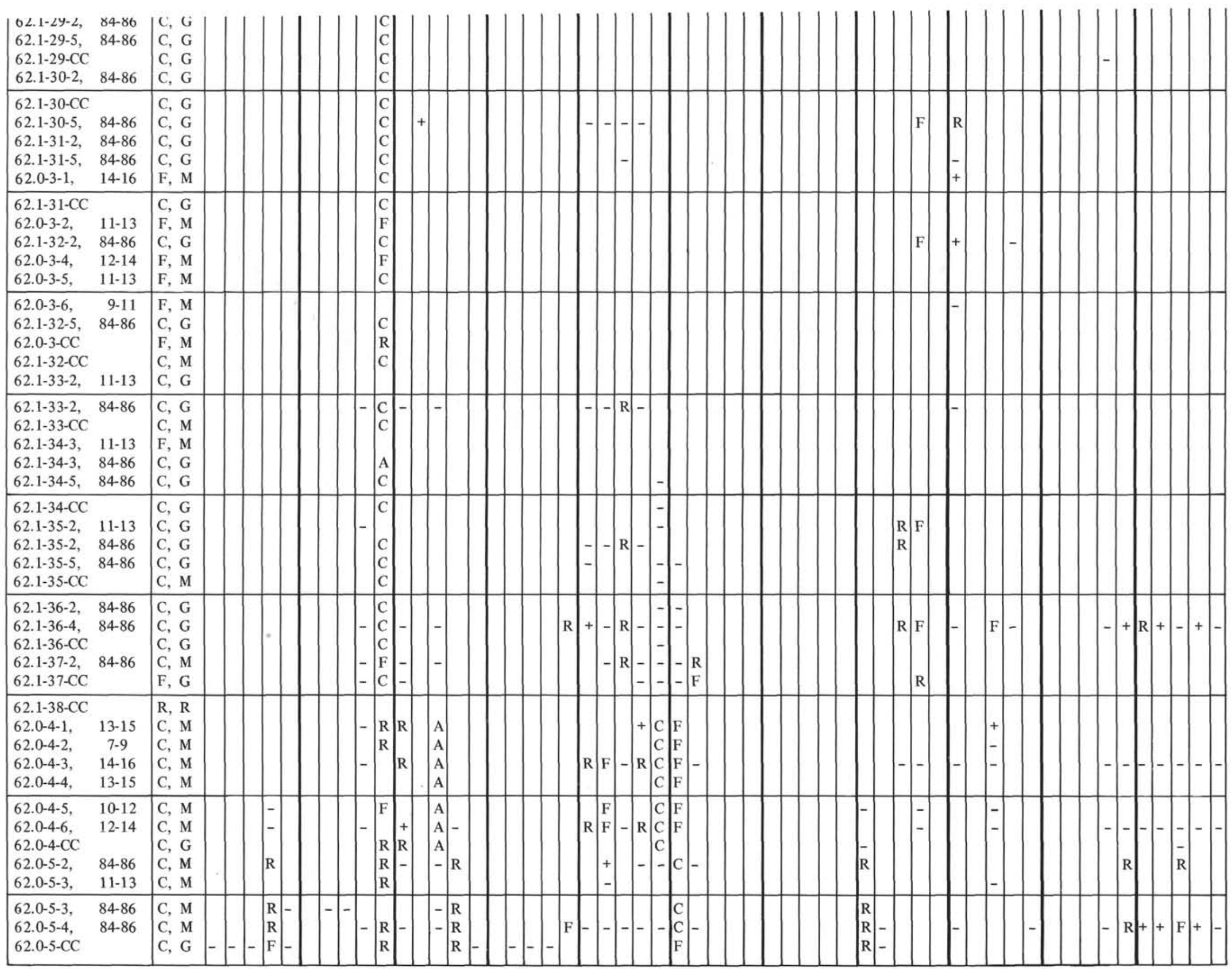


TABLE 2A

Radiolarians at Site 63

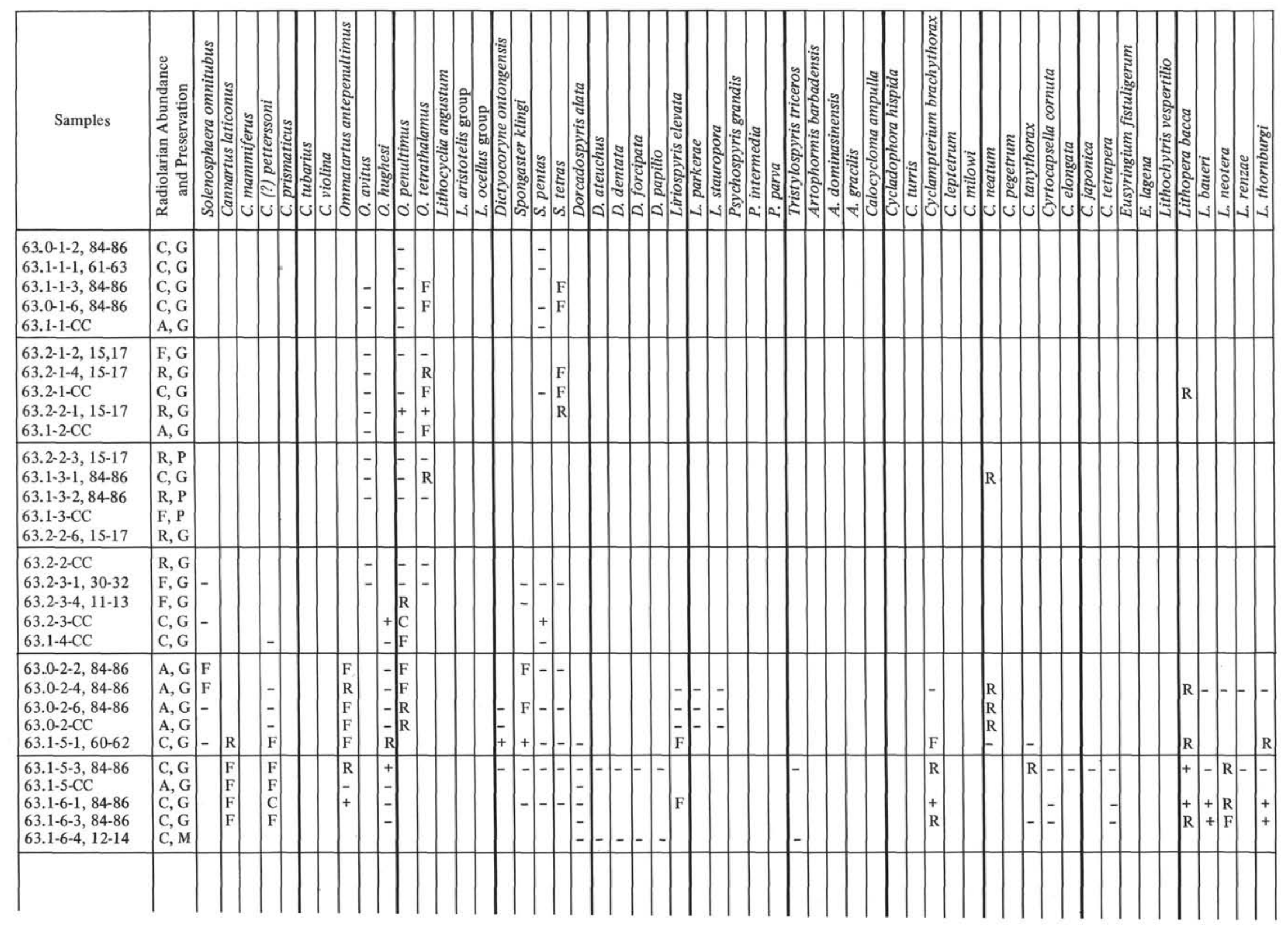


TABLE 2A - Continued

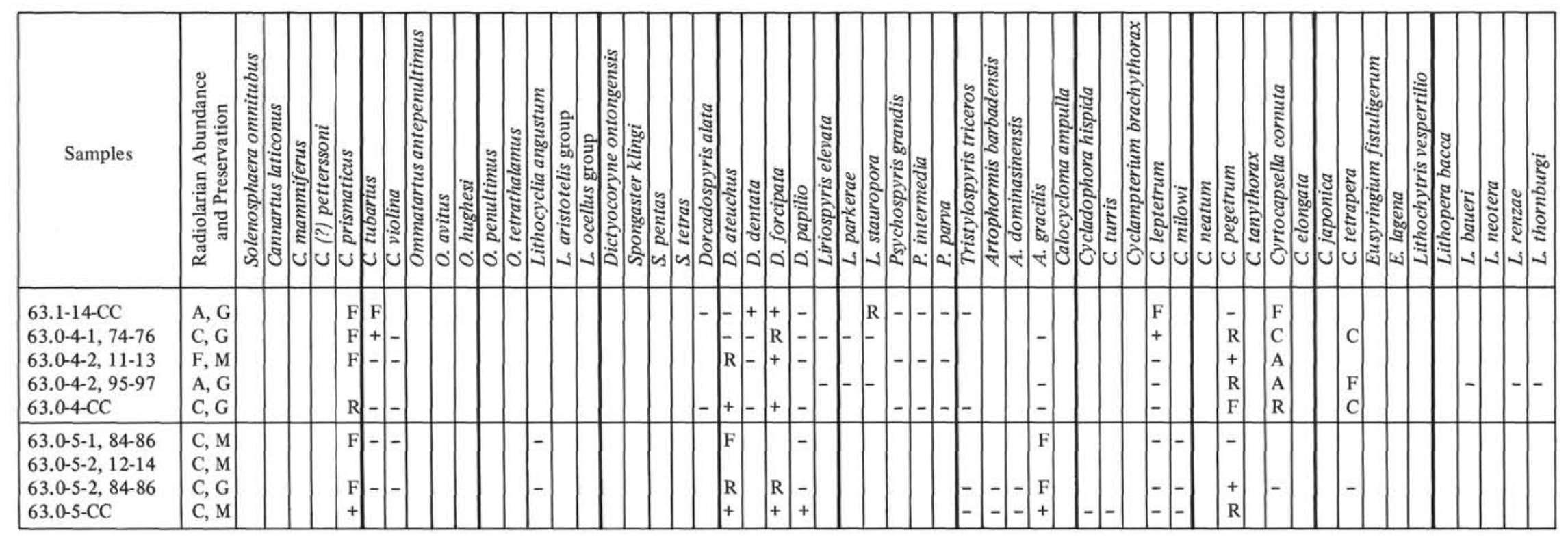


The radiolarian assemblage in 67.1-2-CC includes Phormocyrtis striata, Eucyrtidium cubense, Lithocampium sp. A, Bekoma bidarfensis and Lithochytris archaea with a very poorly developed abdomen (Plate 7, Figure 13). It lacks members of the Lithocyclia ocellus species group and the Lithocampium sp. described in our Leg 4 report, and is therefore apparently older than any of the Leg 2 meterial described by Cita et al (1970).

The only other Lower Eocene and Paleocene assemblages available to us for comparison are from:

Palmer locality $4131,22.5$ miles $\mathrm{N} 10^{\circ} \mathrm{W}$ of Chirino, Yumuri Valley, Matanzas Province, Cuba (from the Dorothy Palmer Collection at the Paleontological Research Institute, Ithaca, New York). Lower Eocene on the basis of calcareous nannofossils-M. N. Bramlette, personal communication.

Upper Paleocene of the coast section at IbbaritzBidarf, France. Adjacent to Triassic diapir to the north-collected by M. N. Bramlette.

Paleocene at Belus, NE of the junction of the rivers Gave and l'Adour, SW France. On the road to Peyrehorade, 200 meters south of the church at Belus, opposite the farm Cassoua-collected by M. N. Bramlette.

Palmer's Lower Eocene Cuban sample has in common with the Site 67 material Eucyrtidium cubense and Lithochytris archaea, but it lacks Bekoma bidarfensis, and its Lithocampium sp. has quincuncially arranged pores on the third segment.

The Upper Paleocene assemblage from Ibbaritz-Bidarf and the Paleocene assemblage from Belus both lack Lithochytris archaea and Eucyrtidium cubense but include Lithocampium sp. A with the pores of the third segment longitudinally aligned, and representatives of Bekoma-at Ibbaritz-Bidarf the same species as at Site 67 , and at Belus an apparently ancestral species.

The above observations suggest that the Site 67 assemblage may be intermediate in age between Palmer's Cuban sample and the Upper Paleocene at IbbaritzBidarf, and thus very near the Eocene/Paleocene boundary.

\section{TIME-RANGES OF TAXA, AND BIOSTRATIGRAPHIC ZONATION}

For the purposes of establishing levels of correlation between the sequences cored at the various sites, and determining a radiolarian zonation applicable to the western tropical Pacific, it has been necessary to arrange the observed radiolarian "events" (upper and lower limits of taxa, and evolutionary transitions) in chronological order. Table 6 presents this chronological arrangement, using the following abbreviations. In the left- and right-hand columns, $\mathrm{T}$ indicates the top of the range of a taxon, B its bottom, and an arrow an evolutionary transition; $\mathrm{e}$ and $\mathrm{m}$ indicate evolutionary and morphotypic limits, respectively (see Section 2). In the body of the table are given the pairs of core-sections between which an event occurred, followed by the depths in meters below the sediment surface. The letters P, M and G (for poor, moderate and good) are used to indicate the degree of reliability of each event at each site-a low level of reliability is in some cases a result of poor preservation of the radiolarian assemblage, and in others a result of scarcity of the taxon. Because of the extensive reworking at Site 65, only lower limits of taxa could be determined there, and all events are recorded as morphotypic-these are of course not precisely comparable with evolutionary events at other sites.

In addition to serving as a basis for the summary presentation of radiolarian ranges in Figure 2, one of the obvious uses of Table 6 is as a correlation table between the several drilled sequences. Ideally, the depths should increase downward in each column, but there are some departures from this ideal which cause correlation lines to cross. In such cases, we have used our estimations of the degree of reliability of each event in each sequence to determine which is the most probable order of occurrence of events.

Figure 2 shows the ranges of taxa and the boundaries between radiolarian zones, against a vertical scale corresponding to depth below the sediment surface at Site 64 . Because that site was not cored continuously, and because in some cases more reliable information on the upper and lower limits of taxa was available from Sites 62,63 and 66 , the relative ranges plotted represent a synthesis of the information available from all sites. The letters $\mathrm{e}$ and $\mathrm{m}$ are used to distinguish evolutionary and morphotypic limits, broken lines indicate limits of uncertainty in the ranges of taxa, and hachured zones indicate ranges of uncertainty in zonal boundaries. Because of poor preservation of the radiolarians at some sites, and discontinuity of coring at other sites, Leg 7 results are not very useful for zones younger than the Ommatartus penultimus Zone and older than the Theocyrtis tuberosa Zone. More useful information on those parts of the section are given in our report on the radiolarians from Leg 4 (Riedel and Sanfilippo, in press), and presumably also in the Initial Reports on Legs 5 and 6.

The radiolarian zonation applicable to the Leg 7 sequences differs in some respects from that which we have published earlier (Riedel and Sanfilippo, in press). This is undoubtedly due in large part to the fact that several long sequences not greatly complicated by the effects of reworking are available from the Leg 7 sites, and the ranges of taxa in them can be determined more 
TABLE 2B

落

Radiolarians at Site 63

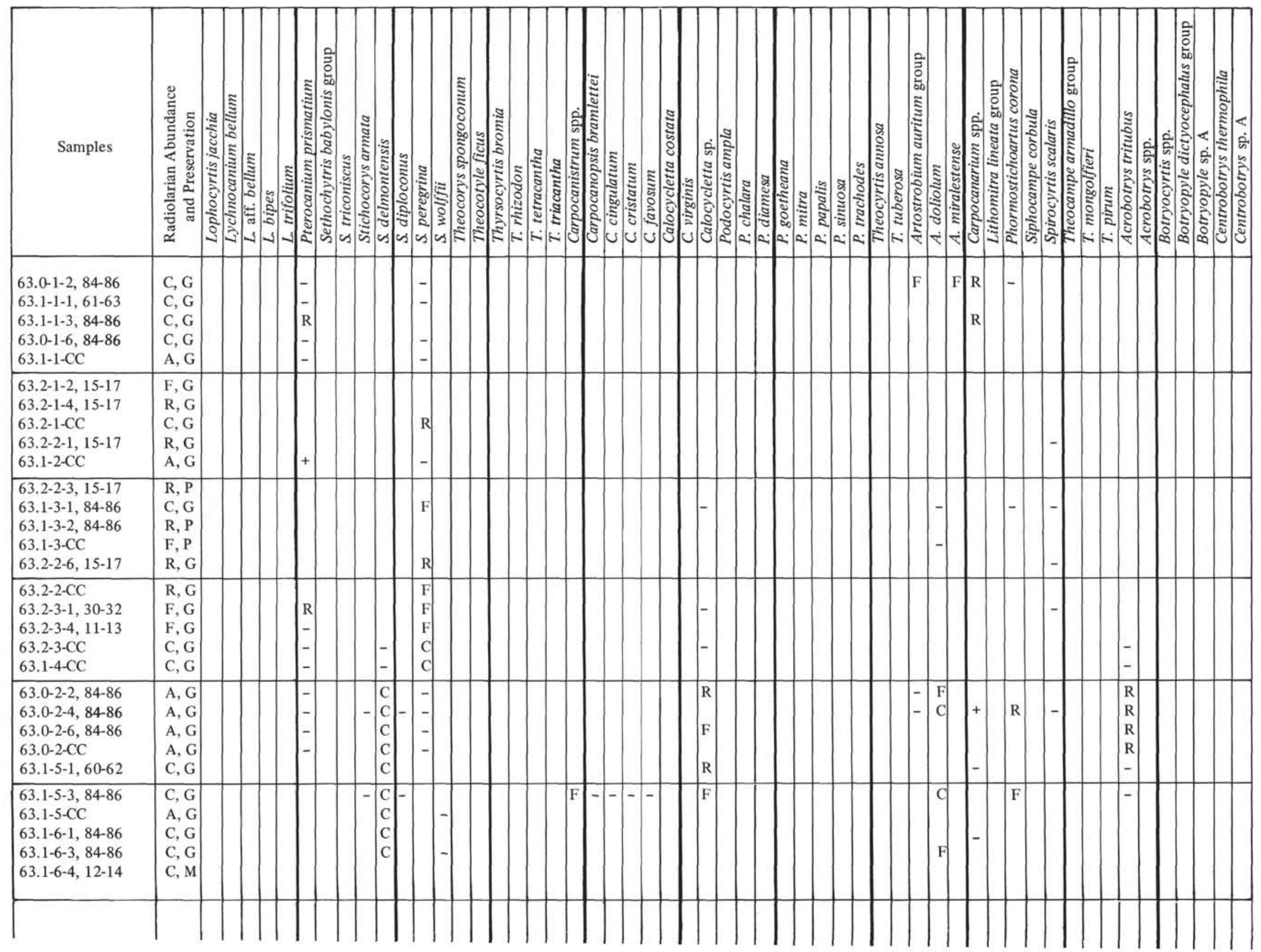




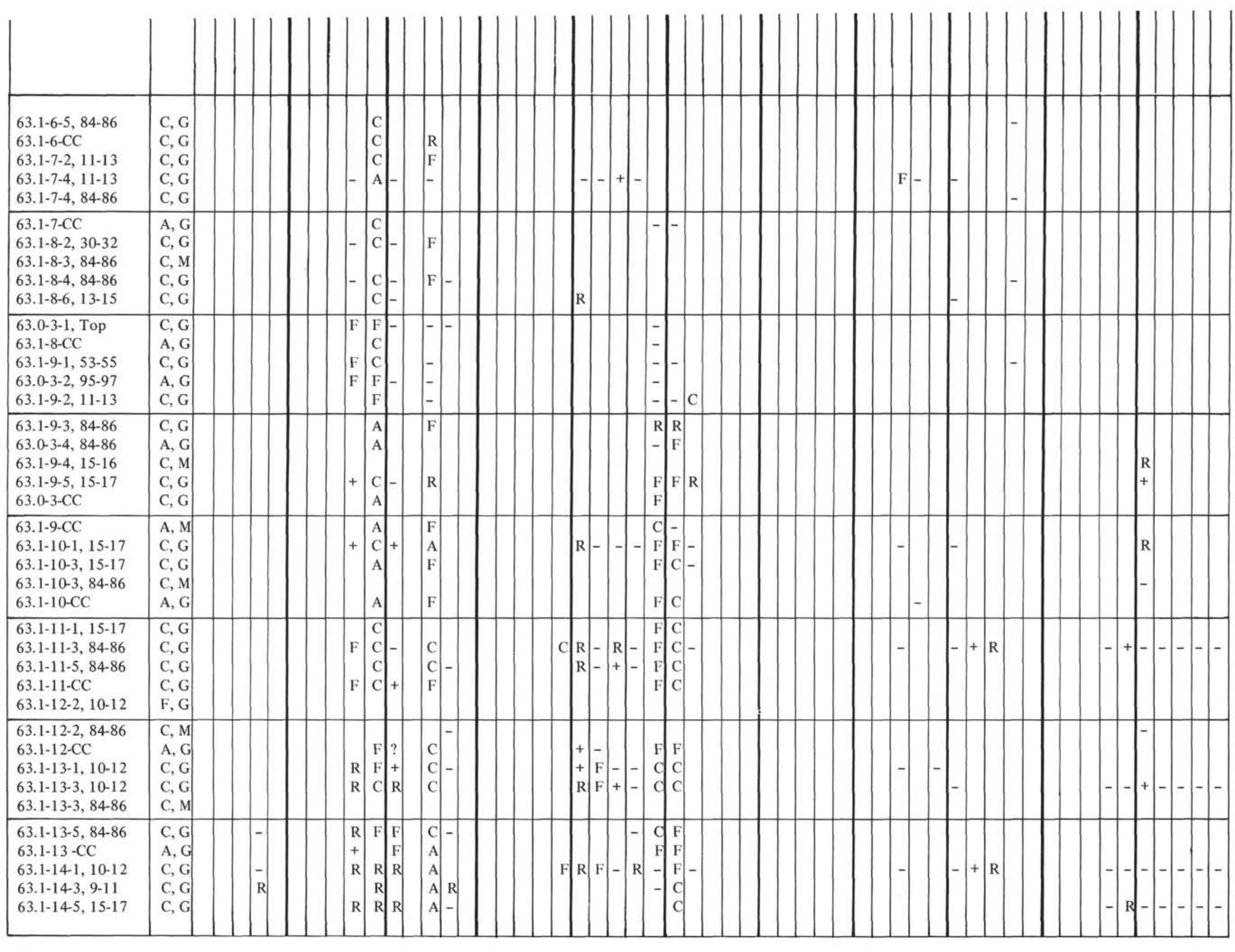




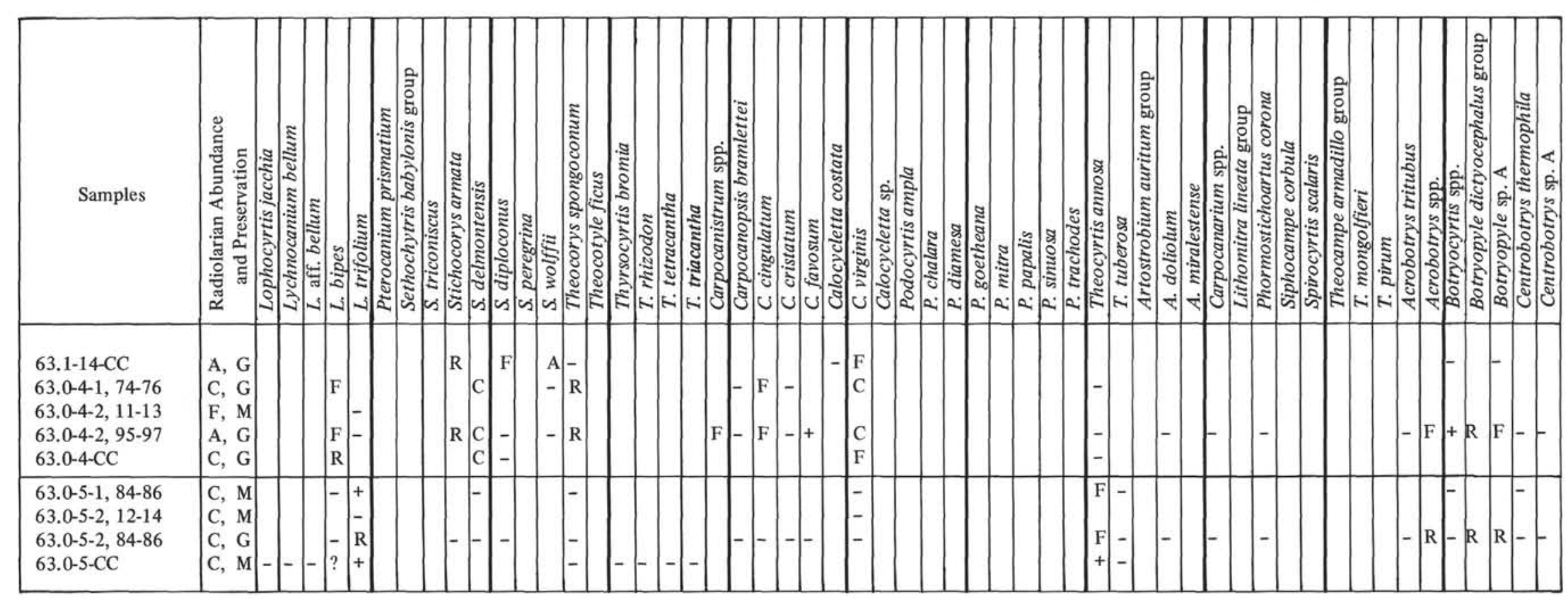


reliably than in the short cores on which our earlier zonation was based. However, some of the discrepancies may also be due to real differences between the relative ranges of taxa in different parts of the tropical oceans, though evaluation of the extent to which this is true must await investigation of sequences from other legs of the drilling expedition.

The principal differences between the present and earlier zonations result from the facts that we have found it necessary (1) to eliminate the Cannartus laticonus Zone because the upper part of the range of Dorcadospyris alata is found to overlap the earliest occurrence of Cannartus (?) petterssoni, and (2) to insert the new Dorcadospyris ateuchus Zone between the Theocyrtis tuberosa and Lychnocanium bipes Zones to accommodate assemblages of an age from which we had previously no samples.

The radiolarian zones well represented in the Leg 7 sequences, and some events within them, are listed from older to younger.

\section{Theocyrtis tuberosa Zone:}

Base defined by the earliest evolutionary appearance of Lithocyclia angustum, which is approximately synchronous with the earliest evolutionary appearance of Artophormis gracilis, the earliest morphotypic appearance of Centrobotrys sp. A, and the latest occurrence of Theocampe pirum. The transition from Theocyrtis tuberosa to $T$. annosa probably occurs near the top of this zone.

\section{Dorcadospyris ateuchus Zone:}

Base defined by the earliest evolutionary appearance of Dorcadospyris ateuchus, which is approximately synchronous with the earliest morphotypic appearances of D. forcipata and Cannartus prismaticus. Events within this zone include:

The earliest morphotypic appearance of Dorcadospyris papilio.

The transition from Cyclampterium milowi to C. pegetrum.

The earliest morphotypic appearances of Botryopyle sp. A and Lychnocanium trifolium.

\section{Lychnocanium bipes Zone:}

Base defined by the earliest morphotypic appearance of Lychnocanium bipes. Events within this zone include:

The latest occurrences of Lithocyclia angustum, Lychnocanium trifolium and Artophormis gracilis.

The earliest morphotypic appearances of Psychospyris parva, Carpocanopsis cingulatum and Cyrtocapsella tetrapera.

The transition from Psychospyris parva to $P$. intermedia.

\section{Calocycletta virginis Zone:}

Base defined by the earliest morphotypic appearance of Calocycletta virginis, which is approximately synchronous with the earliest morphotypic appearance of Cyrtocapsella tetrapera and the latest occurrence of Dorcadospyris papilio. Events within this zone include:

The earliest morphotypic appearances of Botryocyrtis spp. and Carpocanopsis favosum.

The latest occurrences of Dorcadospyris ateuchus and Theocyrtis annosa.

The earliest morphotypic appearances of Stichocorys delmontensis, S. armata, Cannartus tubarius and Carpocanopsis bramlettei.

The transition from Cyclampterium pegetrum to $C$. leptetrum.

The earliest morphotypic appearances of Stichocorys wolffii and Liriospyris stauropora.

The latest occurrences of Botryopyle sp. A and Theocorys spongoconum. The transition from Cannartus tubarius to $C$. violina.

The earliest morphotypic appearances of Dorcadospyris dentata and Stichocorys diploconus.

\section{Calocycletta costata Zone:}

Base defined by the earliest evolutionary appearance of Calocycletta costata, which is approximately synchronous with the latest occurrence of Lychnocanium bipes. Events within this zone include:

The earliest morphotypic appearances of Carpocanopsis cristatum and Phormostichoartus corona.

The latest occurrences of Carpocanopsis cingulatum, Stichocorys diploconus, Cannartus prismaticus, Carpocanopsis favosum and Dorcadospyris forcipata.

The earliest morphotypic appearance of Lithopera renzae.

The transition from Cannartus violina to C. mammiferus.

\section{Dorcadospyris alata Zone:}

Base defined by the earliest evolutionary appearance of Dorcadospyris alata, which is approximately synchronous with the transitions from Liriospyris stauropora to L. parkerae and from Psychospyris intermedia to $P$. grandis. Events within this zone include:

The latest occurrences of Dorcadospyris dentata, Calocycletta costata, C. virginis and Psychospyris grandis.

The transition from Cyclampterium leptetrum to $C$. tanythorax.

The latest occurrences of Liriospyris parkerae and Cyrtocapsella tetrapera.

The earliest morphotypic appearances of Lithopera baueri and $L$. thornburgi. 
TABLE 3A

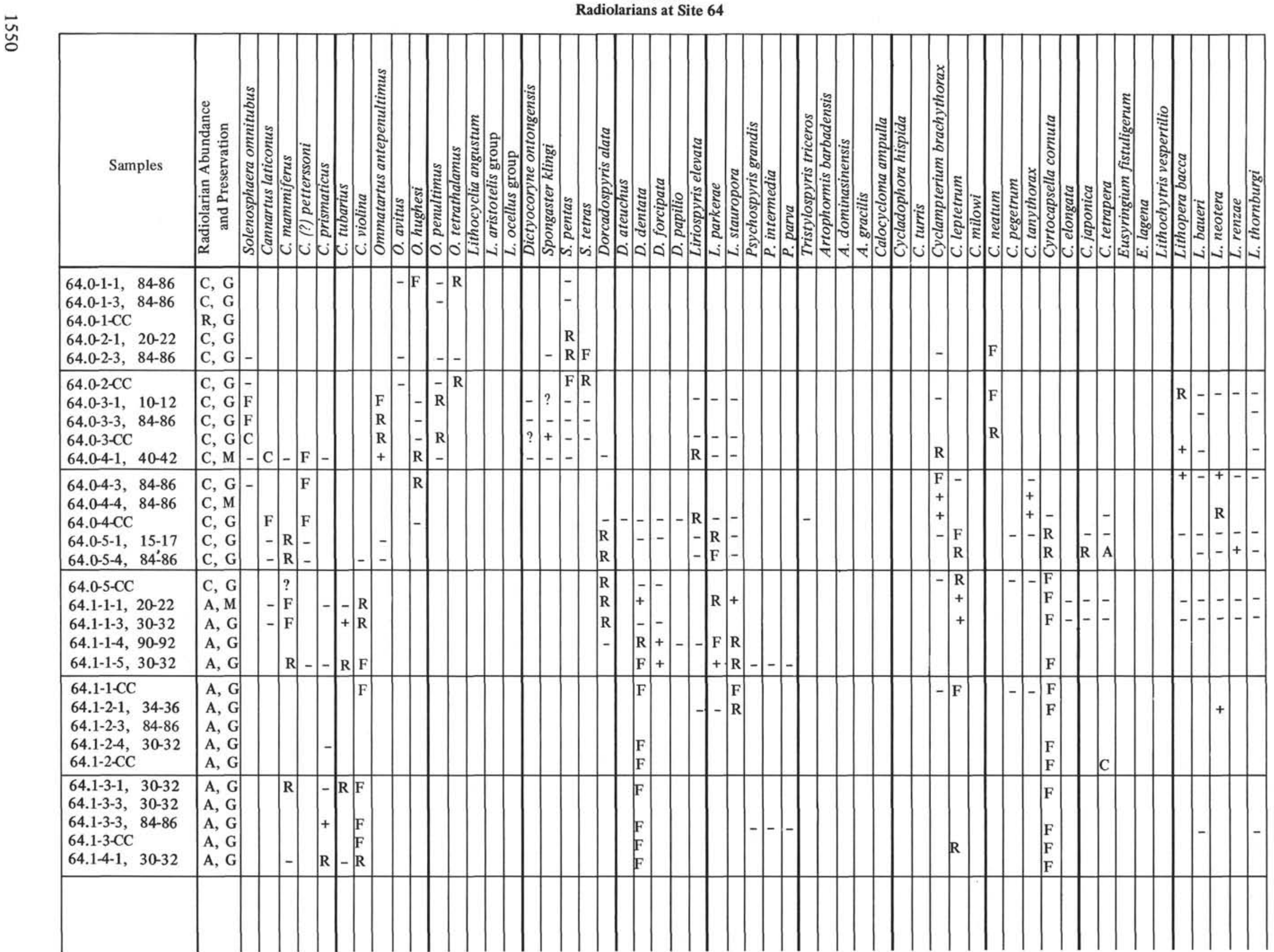




\begin{tabular}{|c|c|c|c|c|c|c|c|c|c|c|c|c|c|c|c|c|c|c|c|c|c|c|c|c|c|c|c|c|}
\hline $\begin{array}{ll}64.1-4-3, & 84-86 \\
64.1-4-4, & 30-32 \\
64.1-4-C C & \\
64.1-5-1, & 20-22 \\
64.1-5-2, & 84-86 \\
\end{array}$ & \begin{tabular}{|l|} 
A, G \\
A, G \\
A, G \\
A, M \\
A, M
\end{tabular} & - & $\begin{array}{c}\mathrm{R} \\
\mathrm{R} \\
+ \\
\end{array}$ & \begin{tabular}{|l|l|} 
& $F$ \\
$R$ & $F$ \\
\end{tabular} & & & & & & & \begin{tabular}{|l|l|l}
$\mathrm{F}$ & $\mathrm{F}$
\end{tabular} & $\mathrm{F}$ & & $\mathrm{R}$ & & & & & & $\mathrm{R}$ & - & $\begin{array}{r}- \\
-F \\
F \\
F\end{array}$ & & & & & & \\
\hline $\begin{array}{l}64.1-5-3, \quad 84-86 \\
64.1-5-\mathrm{CC} \\
64.0-6-1, \quad 11-13 \\
64.0-6-4, \quad 11-13 \\
64.0-6-4, \quad 84-86\end{array}$ & \begin{tabular}{|l|}
$\mathrm{A}, \mathrm{M}$ \\
$\mathrm{A}, \mathrm{G}$ \\
$\mathrm{C}, \mathrm{G}$ \\
$\mathrm{C}, \mathrm{G}$ \\
$\mathrm{C}, \mathrm{M}$
\end{tabular} & - & $\begin{array}{l}- \\
\mathrm{R} \\
\mathrm{R}\end{array}$ & \begin{tabular}{|l|l}
$R$ & $R$ \\
$F$ & \\
$F$ & $R$ \\
$F$ & - \\
\end{tabular} & & & & & & - & $-\mathrm{F}_{-}^{\mathrm{F}}$ & $\mathbf{R}$ & - & F & -- & & & & & $\begin{array}{l}\mathrm{R} \\
\mathrm{F} \\
\mathrm{R}\end{array}$ & - & $-\begin{array}{l}F \\
F \\
F \\
F\end{array}$ & $\begin{array}{ll}R \\
R \\
R\end{array}$ & $\begin{array}{l}- \\
- \\
- \\
-\end{array}$ & & & - & - \\
\hline $\begin{array}{l}64.0-6-\mathrm{CC} \\
64.1-6-1, \quad 30-32 \\
64.1-6-3, \quad 30-32 \\
64.1-6-C \mathrm{CC} \\
64.0-7-1, \quad 11-13\end{array}$ & \begin{tabular}{|l|}
$\mathrm{C}, \mathrm{G}$ \\
$\mathrm{A}, \mathrm{G}$ \\
$\mathrm{A}, \mathrm{G}$ \\
$\mathrm{A}, \mathrm{G}$ \\
$\mathrm{A}, \mathrm{G}$
\end{tabular} & & \begin{tabular}{|l|}
$R$ \\
$R$ \\
$F$ \\
$F$ \\
$F$
\end{tabular} & $\begin{array}{l}F \\
- \\
- \\
- \\
- \\
-\end{array}$ & & & & & & - & 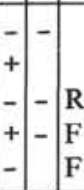 & \begin{tabular}{l|l} 
& - \\
+ \\
$\mathrm{R}$ \\
$\mathrm{F}$ \\
$\mathrm{F}$ \\
$\mathrm{F}$ & + \\
+
\end{tabular} & $-1-$ & $-{ }_{-}^{-}+$ & \begin{tabular}{|l|l|}
- & - \\
+ & - \\
+ & \\
- & - \\
- & -
\end{tabular} & & & & & $\begin{array}{l}\mathrm{R} \\
+ \\
- \\
-\end{array}$ & \begin{tabular}{|l|l}
- \\
$\mathrm{R}$ \\
$\mathrm{R}$ \\
$\mathrm{R}$
\end{tabular} & $\begin{array}{l}F \\
C \\
F \\
-\end{array}$ & -1 & \begin{tabular}{|r|}
- \\
$\mathrm{C}$ \\
$\mathrm{C}$ \\
$\mathrm{C}$ \\
$-\mathrm{C}$
\end{tabular} & & & - & - \\
\hline $\begin{array}{l}64.0-7-3, \quad 30-32 \\
64.0-7-3, \quad 84-86 \\
64.0-7-C C \\
64.1-7-1, \quad 95-97 \\
64.1-7-3, \quad 30-32 \\
\end{array}$ & \begin{tabular}{|l|} 
A, G \\
A, G \\
A, G \\
A, G \\
A, G
\end{tabular} & & $\begin{array}{l}\mathrm{F} \\
\mathrm{F} \\
\mathrm{F} \\
\mathrm{F}\end{array}$ & $\begin{array}{ll}- & - \\
- & - \\
- & - \\
- & \end{array}$ & & & - & & & \begin{tabular}{|ll}
- & - \\
- \\
$R$ \\
- \\
\end{tabular} & \begin{tabular}{l|l}
- & - \\
& $F$ \\
$R$ & $F$ \\
$R$ & - \\
\end{tabular} & \begin{tabular}{|l|l|}
$\mathrm{F}$ & - \\
$\mathrm{F}$ & - \\
& $\mathrm{R}$ \\
+ & $\mathrm{R}$ \\
\end{tabular} & & - - - & $-1-$ & - & $\begin{array}{l}- \\
- \\
- \\
\mathrm{R} \\
\end{array}$ & 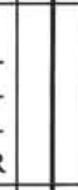 & & - & $\begin{array}{l}\mathrm{R} \\
\mathrm{R} \\
\end{array}$ & $\begin{array}{l}F \\
F \\
- \\
\end{array}$ & - & \begin{tabular}{l|l|}
- & $F$ \\
- & $C$ \\
- & - \\
- & - \\
\end{tabular} & & & & \\
\hline $\begin{array}{l}64 \cdot 1-7-\mathrm{CC} \\
64.0-8-1, \quad 9-11 \\
64 \cdot 0-8-2, \quad 84-86 \\
64.0-8-\mathrm{CC} \\
64.1-8-1,116-118\end{array}$ & \begin{tabular}{|l|} 
A, G \\
A, M \\
A, G \\
A, G \\
A, G
\end{tabular} & & \begin{tabular}{l|}
$\mathrm{F}$ \\
$\mathrm{R}$ \\
$\mathrm{R}$ \\
$\mathrm{R}$ \\
+ \\
\end{tabular} & $\begin{array}{l}- \\
-- \\
-\end{array}$ & & & $\begin{array}{l}- \\
\bar{R} \\
- \\
+ \\
+ \\
+\end{array}$ & & & \begin{tabular}{|l|}
$R$ \\
$F$ \\
$F$ \\
$F$ \\
$F$
\end{tabular} & \begin{tabular}{l|l}
$R$ & $F$ \\
$F$ & $F$ \\
$F$ & - \\
$F$ & - \\
$F$ & -
\end{tabular} & \begin{tabular}{|c|c|}
$\mathrm{R}$ \\
$\mathrm{R}$ \\
$\mathrm{R}$ \\
+ \\
-
\end{tabular} & & & & - & \begin{tabular}{|r|r|} 
& $R$ \\
$R$ \\
$R$ \\
\\
$F$
\end{tabular} & & $-1-$ & $\begin{array}{l}- \\
- \\
- \\
-\end{array}$ & \begin{tabular}{|l|l|} 
& $\begin{array}{l}\mathrm{R} \\
+ \\
\mathrm{R} \\
\mathrm{R}\end{array}$ \\
\end{tabular} & - & - & \begin{tabular}{|l|l|}
- & - \\
\end{tabular} & $-1-$ & $-1-$ & & \\
\hline $\begin{array}{l}64.1-8-2,84-86 \\
64 \cdot 1-8-C \mathrm{CC} \\
64.0-9-\mathrm{CC} \\
64.0-10-1, \text { Top } \\
64.0-10-1,30-32\end{array}$ & $\begin{array}{l}\mathrm{A}, \mathrm{G} \\
\mathrm{A}, \mathrm{G} \\
\mathrm{C}, \mathrm{G} \\
\mathrm{A}, \mathrm{G} \\
\mathrm{A}, \mathrm{G}\end{array}$ & & $\begin{array}{l}- \\
+ \\
+ \\
- \\
-\end{array}$ & & & & $\begin{array}{l}\mathrm{R} \\
\mathrm{R} \\
\mathrm{R} \\
\mathrm{R} \\
\mathrm{R}\end{array}$ & & & $\begin{array}{r}- \\
F \\
F \\
R \\
-\end{array}$ & 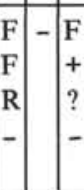 & \begin{tabular}{l|l|} 
F & - \\
+ & - \\
$?$ & - \\
- & -
\end{tabular} & & & & \begin{tabular}{|l|l}
- & \\
- & - \\
- & - \\
$\mathrm{R}$ & - \\
& -
\end{tabular} & $-\begin{array}{l}F \\
F \\
R \\
R \\
F\end{array}$ & - & - & $\begin{array}{r}-\mathrm{F} \\
- \\
+ \\
- \\
\mathrm{F}\end{array}$ & \begin{tabular}{|l|l|} 
& $F$ \\
$F$ \\
$F$ \\
$F$
\end{tabular} & 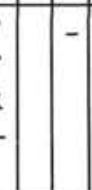 & - & - & 11 & - & & \\
\hline $\begin{array}{l}64.0-10-2,11-13 \\
64.0-10-2,84-86 \\
64.1-9-1, \quad 30-32 \\
64.1-9-2 \quad 84-86 \\
64.1-9-\mathrm{CC}\end{array}$ & $\begin{array}{l}\mathrm{A}, \mathrm{G} \\
\mathrm{C}, \mathrm{G} \\
\mathrm{A}, \mathrm{G} \\
\mathrm{A}, \mathrm{G} \\
\mathrm{A}, \mathrm{G}\end{array}$ & & & & & & \begin{tabular}{|l|l|}
$\mathrm{R}$ & \\
+ & + \\
$\mathrm{F}$ \\
$\mathrm{F}$ \\
- \\
$\mathrm{F}$
\end{tabular} & & & $\begin{array}{l}- \\
- \\
-\end{array}$ & $\begin{array}{l}- \\
- \\
-\end{array}$ & - & & & & \begin{tabular}{|l|l|}
$\mathrm{R}$ & - \\
$\mathrm{R}$ & $\mathrm{R}$ \\
$\mathrm{F}$ & $\mathrm{F}$ \\
$\mathrm{F}$ & $\mathrm{F}$ \\
$\mathrm{R}$ & $\mathrm{F}$ \\
\end{tabular} & \begin{tabular}{|l|l|} 
& $F$ \\
- & $F$ \\
$R$ & $R$ \\
& $F$ \\
\end{tabular} & $\begin{array}{l}- \\
-- \\
- \\
-\end{array}-$ & - & $\begin{array}{l}\mathrm{F} \\
\mathrm{R} \\
- \\
-\end{array}$ & 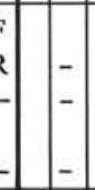 & & & & $\begin{array}{l}- \\
- \\
- \\
- \\
-\end{array}-$ & $\begin{array}{l}- \\
- \\
-\end{array}$ & & \\
\hline $\begin{array}{l}64.1-10-1,30-32 \\
64 \cdot 1-10-2,84-86 \\
64.1-10-\text { CC } \\
64.1-11-C C\end{array}$ & $\begin{array}{l}\text { A, G } \\
\text { A, G } \\
\text { A, G } \\
\text { F, P }\end{array}$ & & & & & & - & \begin{tabular}{|c|}
$\mathrm{R}$ \\
+ \\
+ \\
\end{tabular} & & & & & & & & - & \begin{tabular}{|l|l|}
- & - \\
& - \\
+ & - \\
\end{tabular} & \begin{tabular}{|l|l}
$R$ & $F$ \\
$F$ & $F$ \\
$F$ & $F$
\end{tabular} & $\begin{array}{l}- \\
- \\
+\end{array}$ & & & & & & \begin{tabular}{|l|l|}
$\mathrm{F}$ & - \\
$\mathrm{F}$ & \\
$\mathrm{F}$ & \\
+ & \\
\end{tabular} & $\begin{array}{l}- \\
- \\
+\end{array}$ & & \\
\hline
\end{tabular}


TABLE 3B

Radiolarians at Site 64

岕

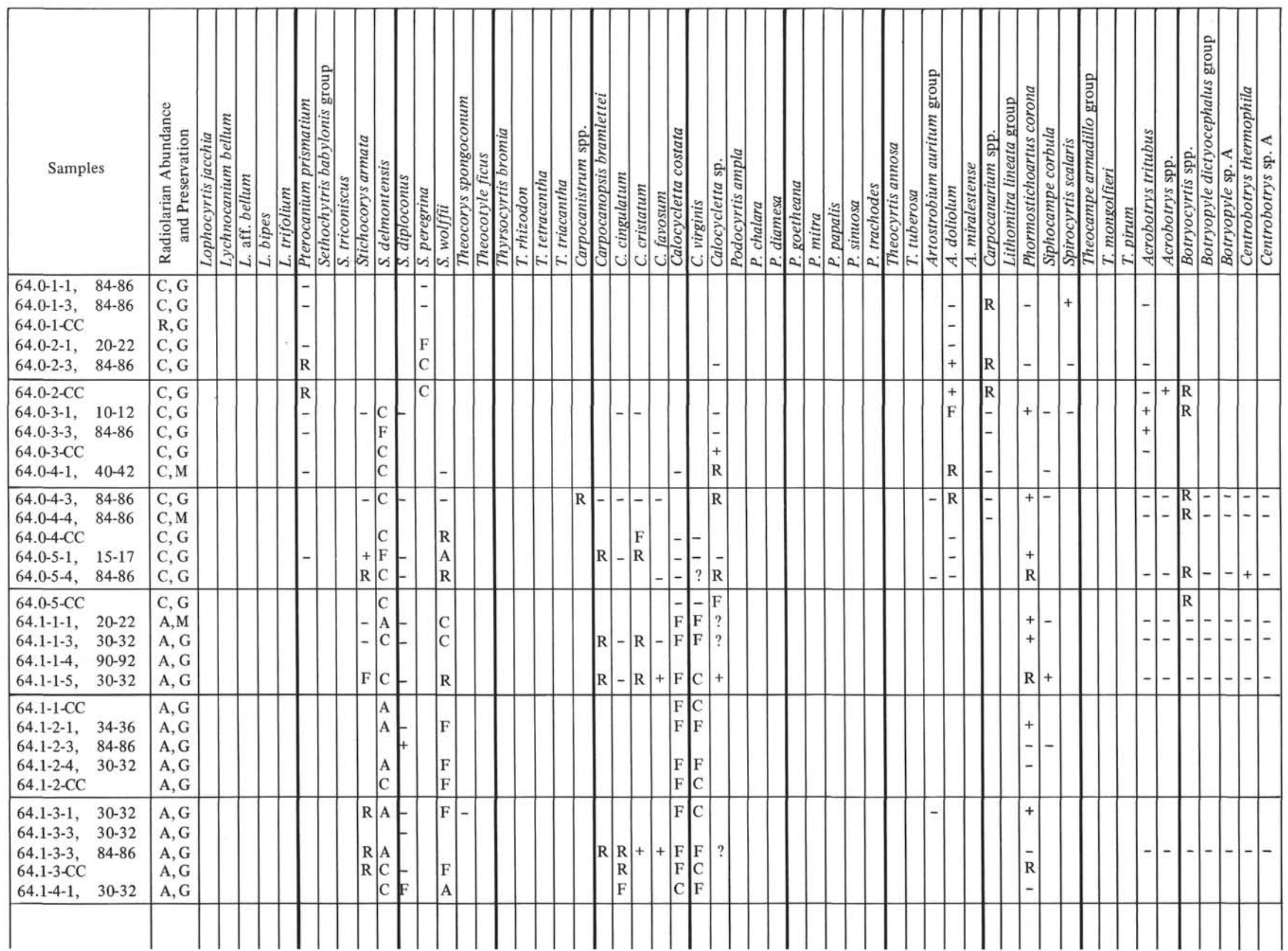




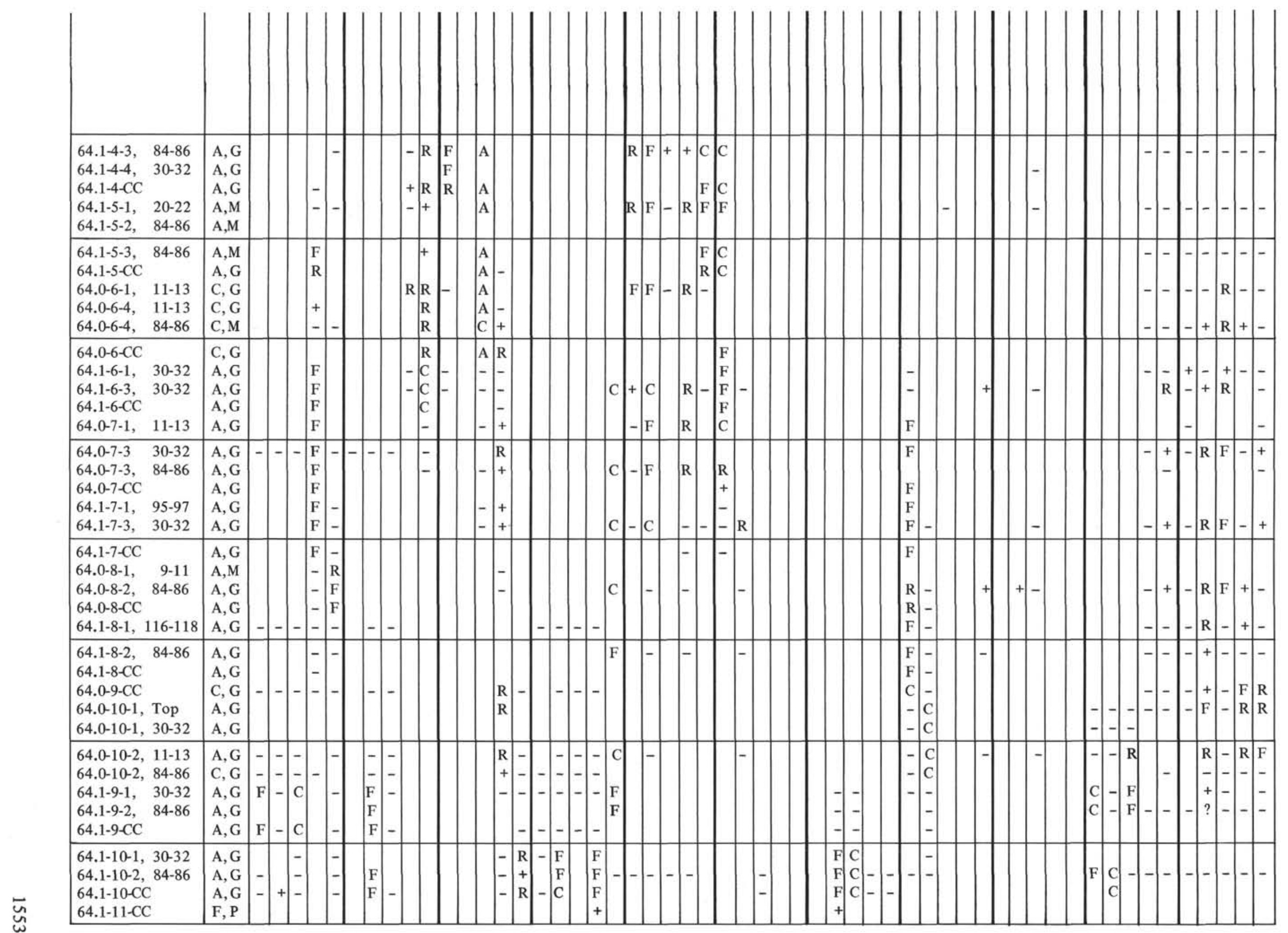


TABLE 4A

Radiolarians at Site 65

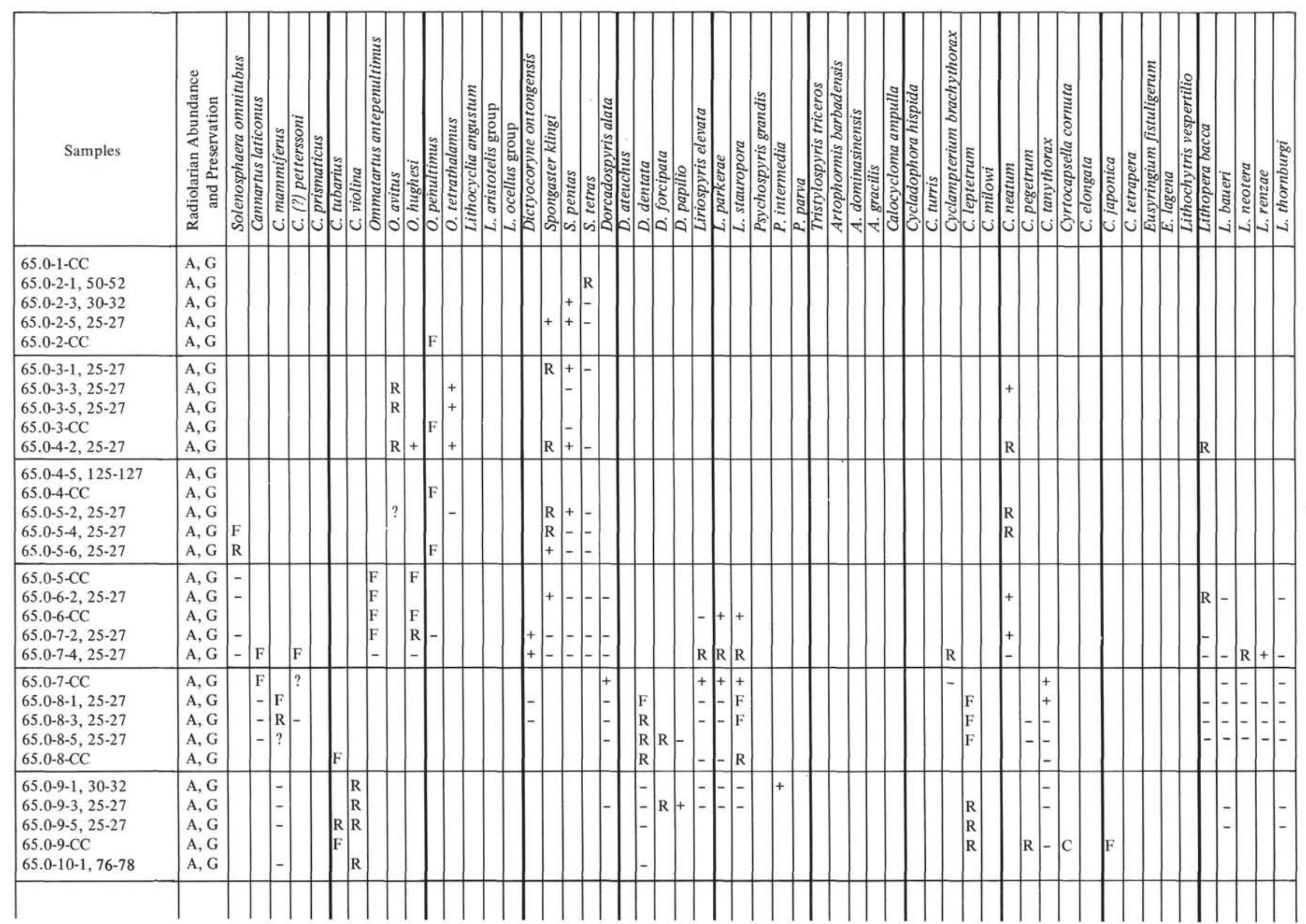


TABLE 4B

Radiolarians at Site 65

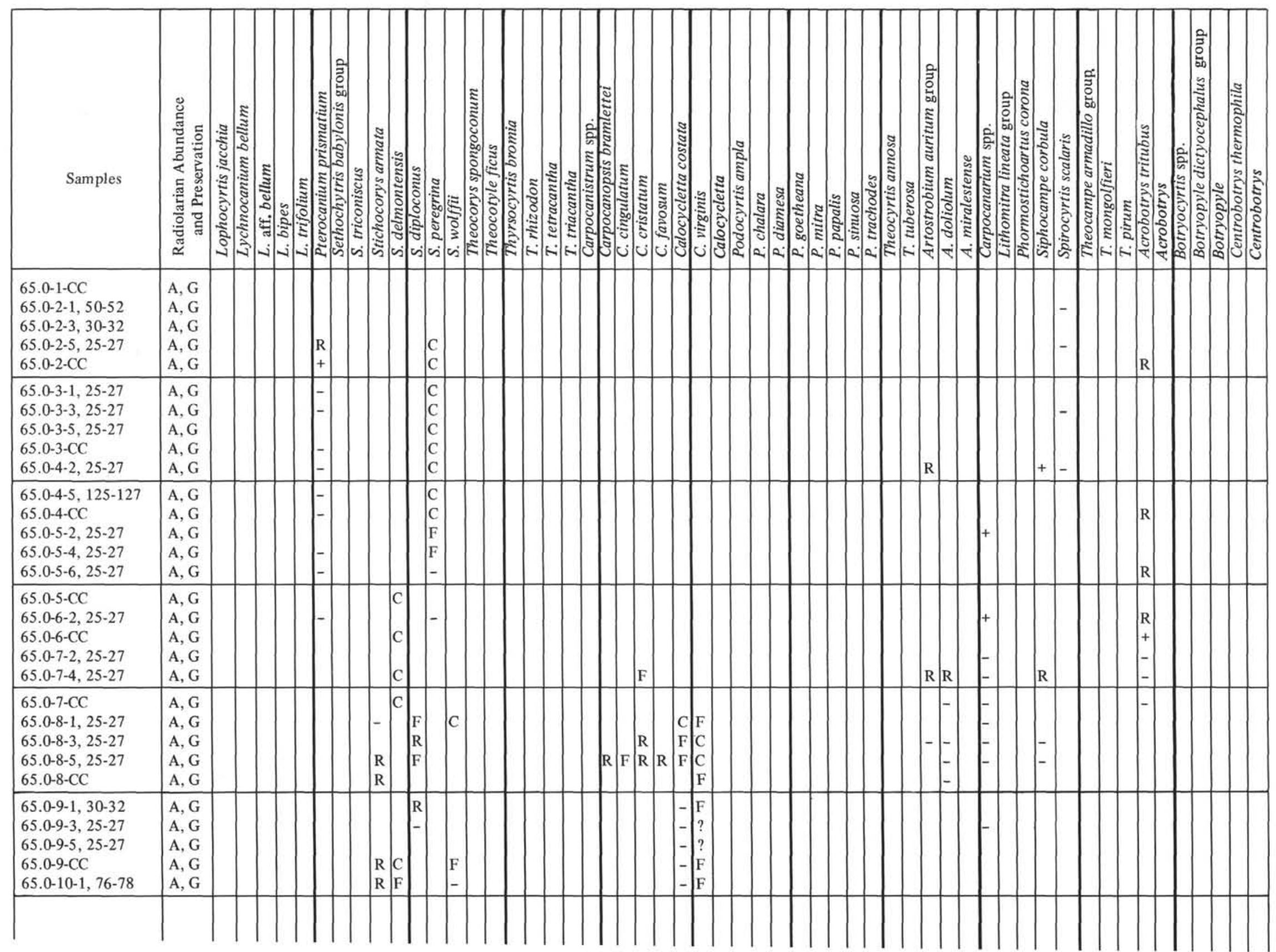




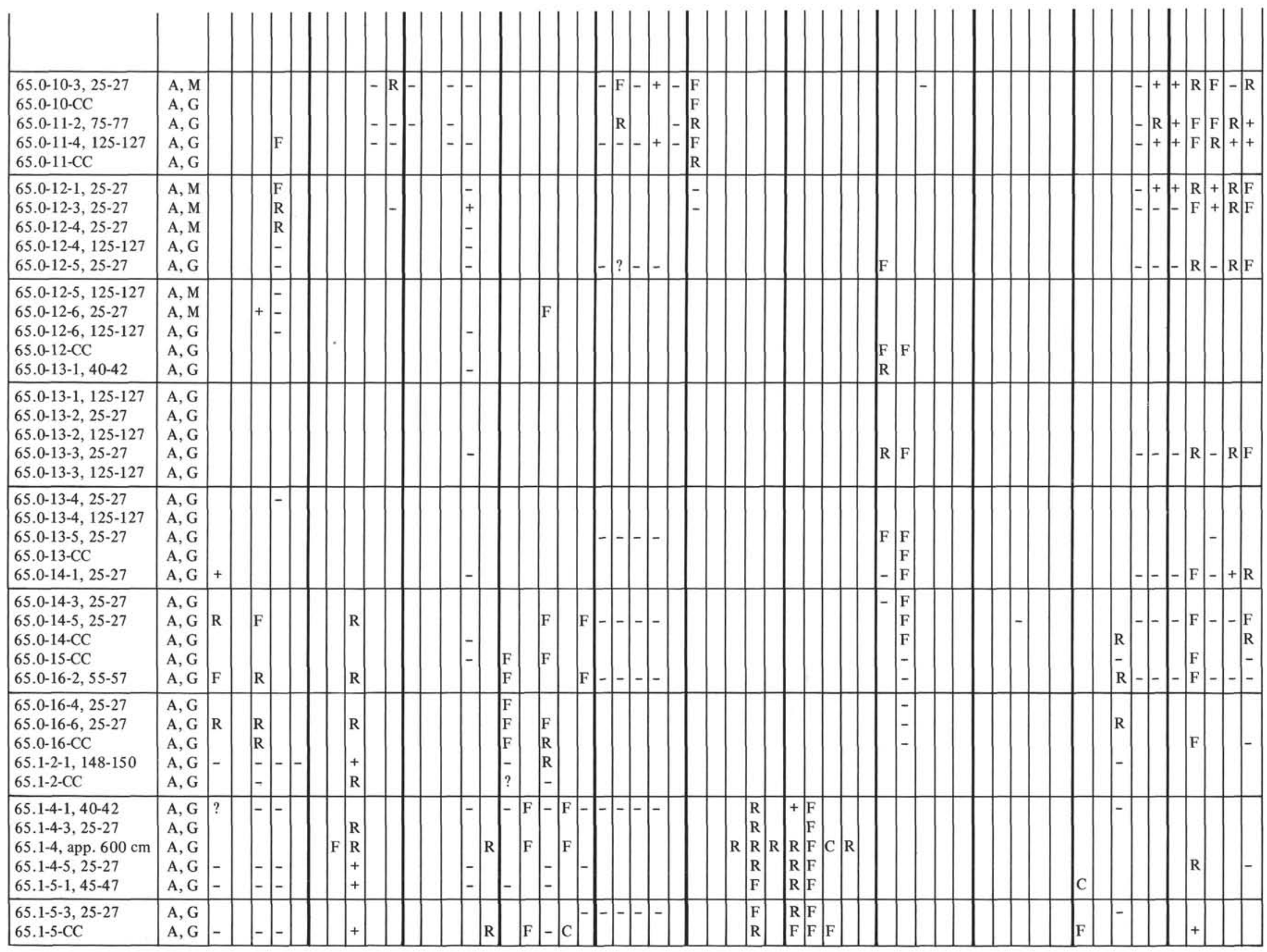


TABLE 5A

Radiolarians at Site 66

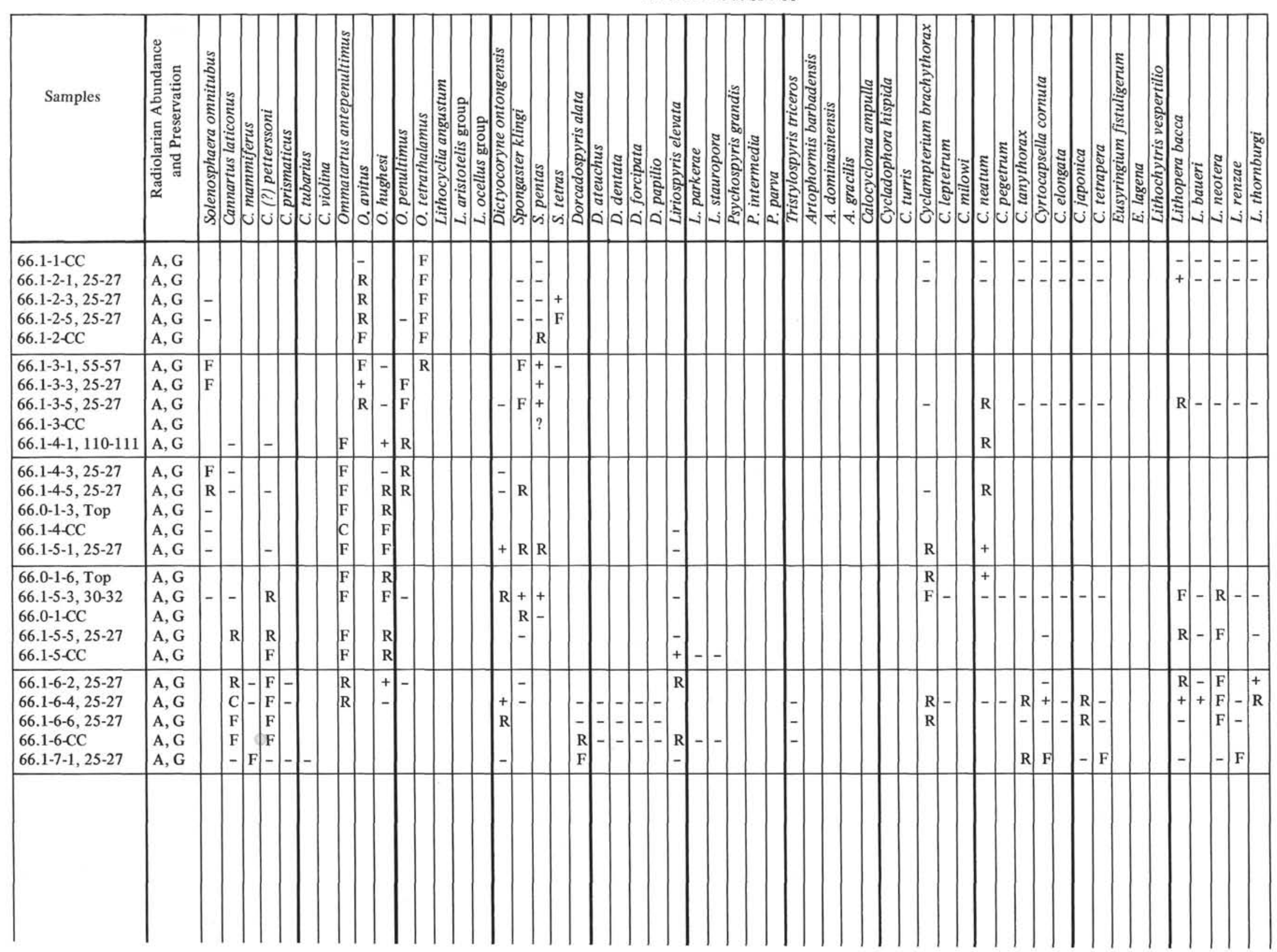




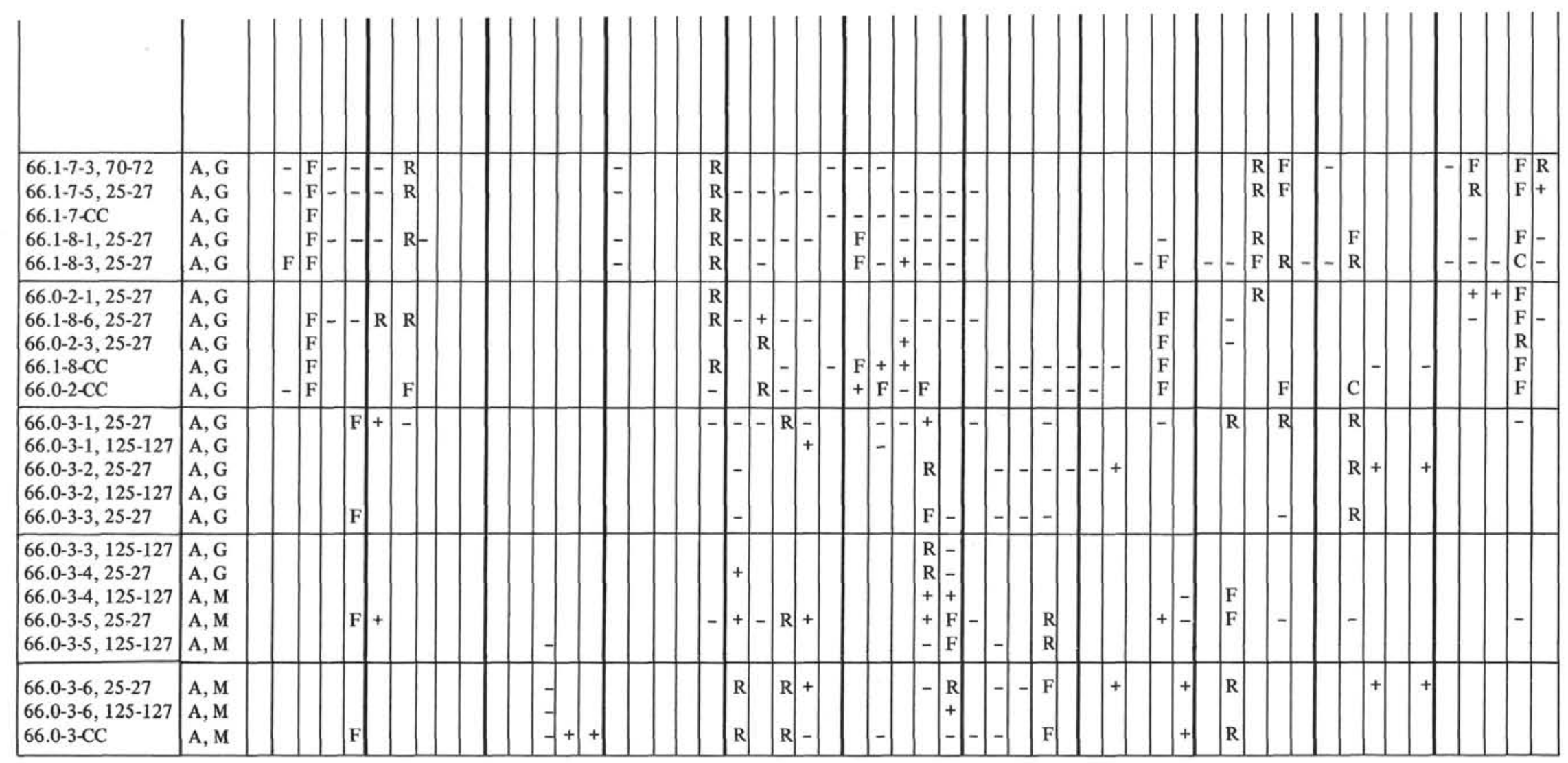


TABLE 5B

Radiolarians at Site 66

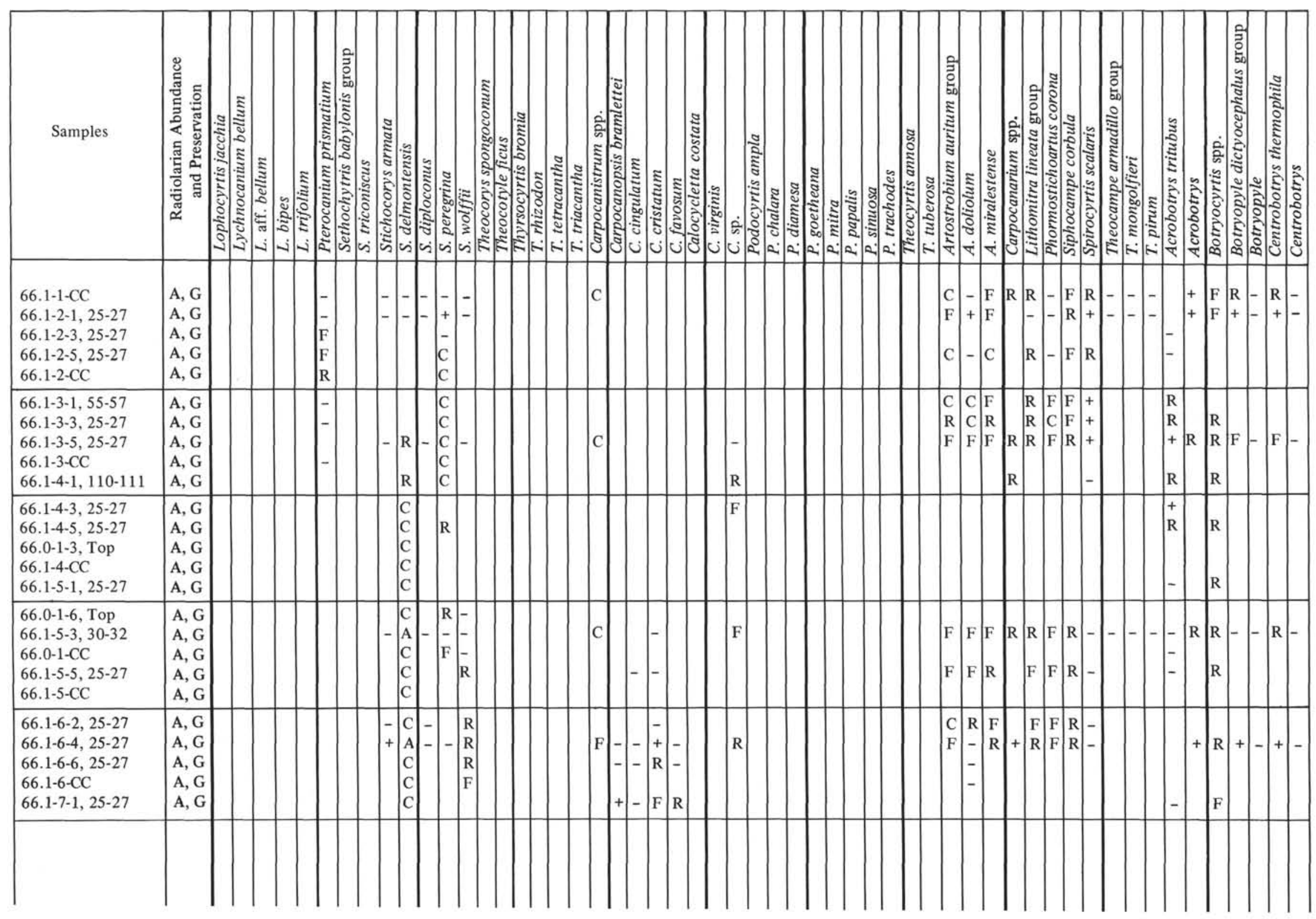




\begin{tabular}{|c|c|c|c|c|c|c|c|c|c|c|c|c|c|c|c|c|c|c|c|c|c|c|c|c|c|c|c|c|c|c|c|}
\hline $\begin{array}{l}66.1-7-3,70-72 \\
66.1-7-5,25-27 \\
66.1-7-\mathrm{CC} \\
66.1-8-1,25-27 \\
66.1-8-3,25-27 \\
\end{array}$ & \begin{tabular}{l|} 
A, G \\
A, G \\
A, G \\
A, G \\
A, G \\
\end{tabular} & & & & & \begin{tabular}{|l|l} 
& $C$ \\
& $C$ \\
& $C$ \\
$F$ & $C$ \\
$F$ & $A$
\end{tabular} & \begin{tabular}{l|l}
$c$ & - \\
$c$ & \\
$c$ & \\
$C$ & - \\
$A$ & - \\
\end{tabular} & $\begin{array}{r} \\
\\
\\
R \\
- \\
R\end{array}$ & & & & C & $\begin{array}{l}+ \\
- \\
R\end{array}-$ & $\begin{array}{l}\mathrm{R} \\
\mathrm{F} \\
\mathrm{R}\end{array}$ & $\begin{array}{l}\mathrm{R} \\
- \\
- \\
- \\
-\end{array}$ & $\begin{array}{l}? \\
\mathrm{R}\end{array}$ & $\mathrm{C}$ & & & & $\begin{array}{l}+ \\
\mathrm{R}\end{array}$ & $-\mathrm{R}$ & \begin{tabular}{|l|l|} 
& \\
$R$ & \\
\end{tabular} & $\mathrm{R}^{\mathrm{B}}$ & \begin{tabular}{l|l}
$\mathrm{R}$ & \\
- & - \\
\end{tabular} & & & $\begin{array}{r} \\
\\
+ \\
\end{array}$ & $\mathrm{R}$. & & \\
\hline $\begin{array}{l}66.0-2-1,25-27 \\
66.1-8-6,25-27 \\
66.0-2-3,25-27 \\
66.1-8-C C \\
66.0-2-C C \\
\end{array}$ & \begin{tabular}{l|} 
A, G \\
A, G \\
A, G \\
A, G \\
A, G \\
\end{tabular} & - & $\begin{array}{l}- \\
- \\
- \\
-\end{array}$ & $\begin{array}{l}- \\
- \\
- \\
- \\
\end{array}$ & & \begin{tabular}{|l|l}
$\mathrm{R}$ & $\mathrm{C}$ \\
$\mathrm{R}$ & $\mathrm{C}$ \\
$\mathrm{F}$ & $\mathrm{C}$ \\
$\mathrm{F}$ & $\mathrm{C}$ \\
$\mathrm{F}$ & $\mathrm{C}$ \\
\end{tabular} & \begin{tabular}{l|l}
$c$ & + \\
$c$ & - \\
$c$ & - \\
$c$ & \\
$c$ & \\
\end{tabular} & $\begin{array}{l}\mathrm{R} \\
\mathrm{R} \\
\mathrm{R}\end{array}$ & $\begin{array}{l}- \\
- \\
- \\
-\end{array}$ & & - & - & $\mathrm{F}-$ & $\mathrm{R}$ & \begin{tabular}{r|r}
1 & 1 \\
1 \\
1 \\
-
\end{tabular} & $\begin{array}{l}R \\
F \\
R \\
F\end{array}$ & C & & & - & & & $\mid \begin{array}{l}\mathrm{R} \\
\mathrm{R} \\
\mathrm{R}\end{array}$ & $\begin{array}{l}\mathrm{F} \\
\mathrm{F}\end{array}$ & & & & & & - & \\
\hline $\begin{array}{l}66.0-3-1,25-27 \\
66.0-3-1,125-127 \\
66.0-3-2,25-27 \\
66.0-3-2,125-127 \\
66.0-3-3,25-27\end{array}$ & $\begin{array}{l}\text { A, G } \\
\text { A, G } \\
\text { A, G } \\
\text { A, G } \\
\text { A, G } \\
\end{array}$ & & - & $\mathrm{C}$ & & - - & $-1-$ & - & + & & +1 & $\mathrm{R}$ & $-R$ & - & + & $\begin{array}{l}+ \\
+ \\
+\end{array}$ & $R$ & & & $F$ & & & - & - & & & & & & $\mathrm{R}$ & \\
\hline $\begin{array}{l}66.0-3-3,125-127 \\
66.0-3-4,25-27 \\
66.0-3-4,125-127 \\
66.0-3-5,25-27 \\
66.0-3-5,125-127\end{array}$ & \begin{tabular}{l|}
$\mathrm{A}, \mathrm{G}$ \\
$\mathrm{A}, \mathrm{G}$ \\
$\mathrm{A}, \mathrm{M}$ \\
$\mathrm{A}, \mathrm{M}$ \\
$\mathrm{A}, \mathrm{M}$ \\
\end{tabular} & & & & & - & & - & & & & $F$ & $+R$ & & + & - & & & & $F$ & & & - & - & & & $-\mathrm{R}$ & $\mathrm{R} /+$ & $\mathrm{F} / \mathrm{P}$ & $\begin{array}{ll}\mathrm{R} & \mathrm{R}\end{array}$ & \\
\hline $\begin{array}{l}66.0-3-6,25-27 \\
66.0-3-6,125-127 \\
66.0-3-C C\end{array}$ & $\begin{array}{l}\mathrm{A}, \mathrm{M} \\
\mathrm{A}, \mathrm{M} \\
\mathrm{A}, \mathrm{M}\end{array}$ & & & C - & - & & & & & & +1 & $\mathrm{R}$ & & & & - & & & & \begin{tabular}{|l|l}
$F$ & + \\
$R$ & $R$ \\
$F$ & $R$
\end{tabular} & & & & & & & & & & & \\
\hline
\end{tabular}


TABLE 6

Radiolarian Events at Sites 62-66 (for explanation, see text Section 5)

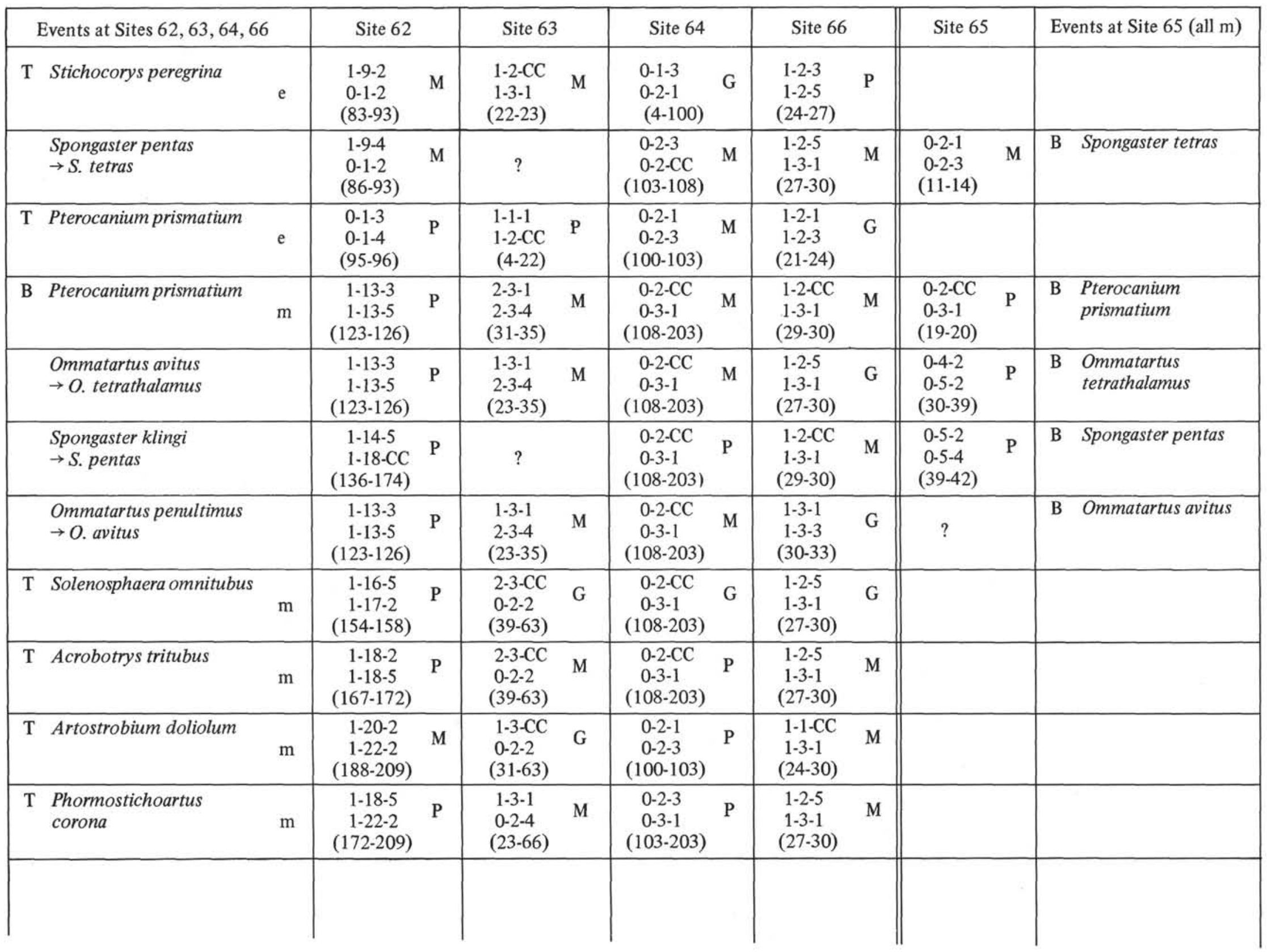




\begin{tabular}{|c|c|c|c|c|c|c|c|c|c|c|c|c|c|c|}
\hline & $\begin{array}{l}\text { Stichocorys delmontensis } \\
\rightarrow S \text {. peregrina }\end{array}$ & & $\begin{array}{r}1-21-5 \\
1-21-\mathrm{CC} \\
(202-204) \\
\end{array}$ & M & $\begin{array}{l}2-3-\mathrm{CC} \\
0-2-2 \\
(39-63)\end{array}$ & G & $\begin{array}{c}0-2-\mathrm{CC} \\
0-3-1 \\
(108-203)\end{array}$ & G & $\begin{array}{l}1-4-1 \\
1-4-3 \\
(39-42)\end{array}$ & G & $\begin{array}{l}0-5-4 \\
0-5-C C \\
(42-46)\end{array}$ & M & B & $\begin{array}{l}\text { Stichocorys } \\
\text { peregrina }\end{array}$ \\
\hline $\mathrm{T}$ & Calocycletta sp. & $\mathrm{m}$ & $?$ & & $\begin{array}{l}2-3-\mathrm{CC} \\
0-2-2 \\
(39-63)\end{array}$ & M & $\begin{array}{c}0-3-3 \\
0-3-C C \\
(206-211)\end{array}$ & $P$ & $\begin{array}{l}1-3-5 \\
1-4-1 \\
(36-39)\end{array}$ & M & & & & \\
\hline & $\begin{array}{l}\text { Ommatartus } \\
\text { antepenultimus } \\
\rightarrow O \text {. penultimus }\end{array}$ & & $\begin{array}{c}1-23-\mathrm{CC} \\
1-24-2 \\
(225-227)\end{array}$ & G & $\begin{array}{l}0-2-4 \\
0-2-6 \\
(66-69)\end{array}$ & G & $\begin{array}{c}0-2-\mathrm{CC} \\
0-3-1 \\
(108-203)\end{array}$ & M & $\begin{array}{l}1-3-5 \\
1-4-1 \\
(36-39)\end{array}$ & G & $\begin{array}{l}0-5-6 \\
0-7-2 \\
(45-57)\end{array}$ & M & B & $\begin{array}{l}\text { Ommatartus } \\
\text { penultimus }\end{array}$ \\
\hline B & $\begin{array}{l}\text { Solenosphaera } \\
\text { omnitubus }\end{array}$ & $\mathrm{m}$ & $\begin{array}{c}1-23-5 \\
1-24-2 \\
(223-227)\end{array}$ & G & $\begin{array}{l}0-2-4 \\
0-2-6 \\
(66-69)\end{array}$ & G & $\begin{array}{c}0-3-\mathrm{CC} \\
0-4-1 \\
(211-305)\end{array}$ & G & $\begin{array}{l}0-1-3 \\
1-4-5 \\
(45-45)\end{array}$ & M & $\begin{array}{l}0-5-6 \\
0-5-\mathrm{CC} \\
(45-46)\end{array}$ & M & B & $\begin{array}{l}\text { Solenosphaera } \\
\text { omnitubus }\end{array}$ \\
\hline B & Acrobotrys tritubus & $\mathrm{m}$ & $\begin{array}{c}1-27-2 \\
1-27-4 \\
(256-259)\end{array}$ & $P$ & $\begin{array}{l}0-2-\mathrm{CC} \\
1-5-1 \\
(70-102)\end{array}$ & M & $\begin{array}{c}0-3-3 \\
0-3-C C \\
(206-211)\end{array}$ & $\mathrm{P}$ & $\begin{array}{l}1-4-5 \\
1-5-1 \\
(45-48)\end{array}$ & M & $\begin{array}{l}0-6-\mathrm{CC} \\
0-7-2 \\
(55-57)\end{array}$ & $\mathrm{P}$ & B & Acrobotrys tritubus \\
\hline $\mathrm{T}$ & $\begin{array}{l}\text { Dictyocoryne } \\
\text { ontongensis }\end{array}$ & $\mathrm{m}$ & $\begin{array}{c}1-27-4 \\
1-28-2 \\
(259-265)\end{array}$ & $P$ & $\begin{array}{l}0-2-\mathrm{CC} \\
1-5-1 \\
(70-102)\end{array}$ & $\mathrm{P}$ & $\begin{array}{c}0-3-3 \\
0-3-C C \\
(206-211)\end{array}$ & $\mathrm{P}$ & $\begin{array}{l}1-4-5 \\
1-5-1 \\
(45-48)\end{array}$ & $\mathrm{P}$ & & & & \\
\hline B & Spongaster klingi & $\mathrm{m}$ & $\begin{array}{c}1-28-5 \\
1-29-5 \\
(270-278)\end{array}$ & $\mathrm{M}$ & $\begin{array}{c}1-5-1 \\
1-5-3 \\
(102-105)\end{array}$ & $\mathrm{P}$ & $\begin{array}{c}0-3-\mathrm{CC} \\
0-4-1 \\
(211-305)\end{array}$ & $\mathrm{P}$ & $\begin{array}{l}1-5-3 \\
1-5-5 \\
(51-54)\end{array}$ & M & $\begin{array}{l}0-6-2 \\
0-7-2 \\
(48-57)\end{array}$ & $\mathrm{P}$ & B & Spongaster klingi \\
\hline & $\begin{array}{l}\text { Cannartus petterssoni } \\
\rightarrow \text { Ommatartus hughesi }\end{array}$ & & $\begin{array}{c}1-29-\mathrm{CC} \\
1-30-2 \\
(280-283)\end{array}$ & G & $\begin{array}{l}2-3-\mathrm{CC} \\
1-5-1 \\
(39-102)\end{array}$ & $\mathrm{P}$ & $\begin{array}{c}0-3-\mathrm{CC} \\
0-4-1 \\
(211-305)\end{array}$ & M & $\begin{array}{l}1-5-3 \\
1-5-\mathrm{CC} \\
(51-56)\end{array}$ & G & $\begin{array}{l}0-7-2 \\
0-7-4 \\
(57-60)\end{array}$ & M & B & Ommatartus hughesi \\
\hline
\end{tabular}


TABLE 6 - Continued

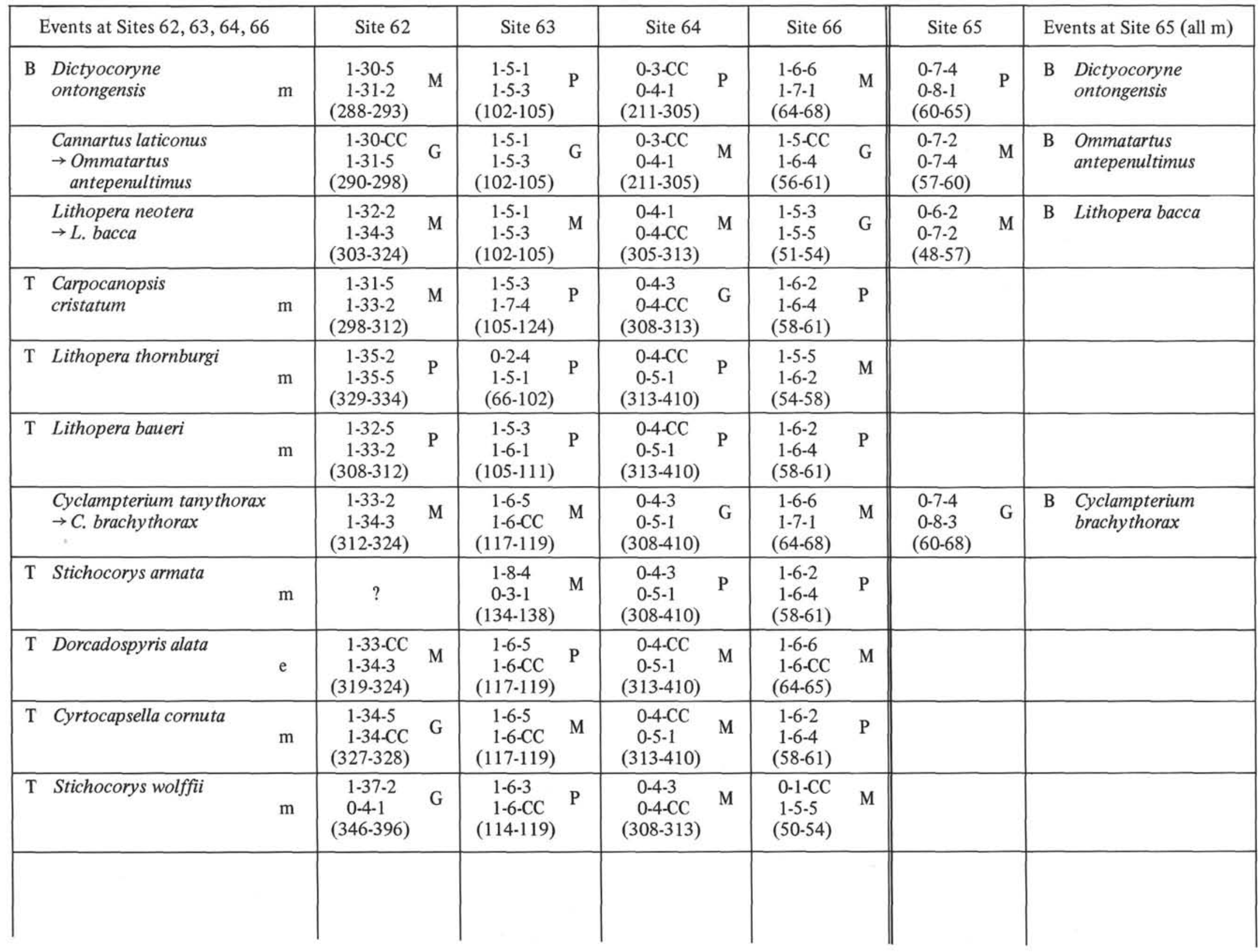




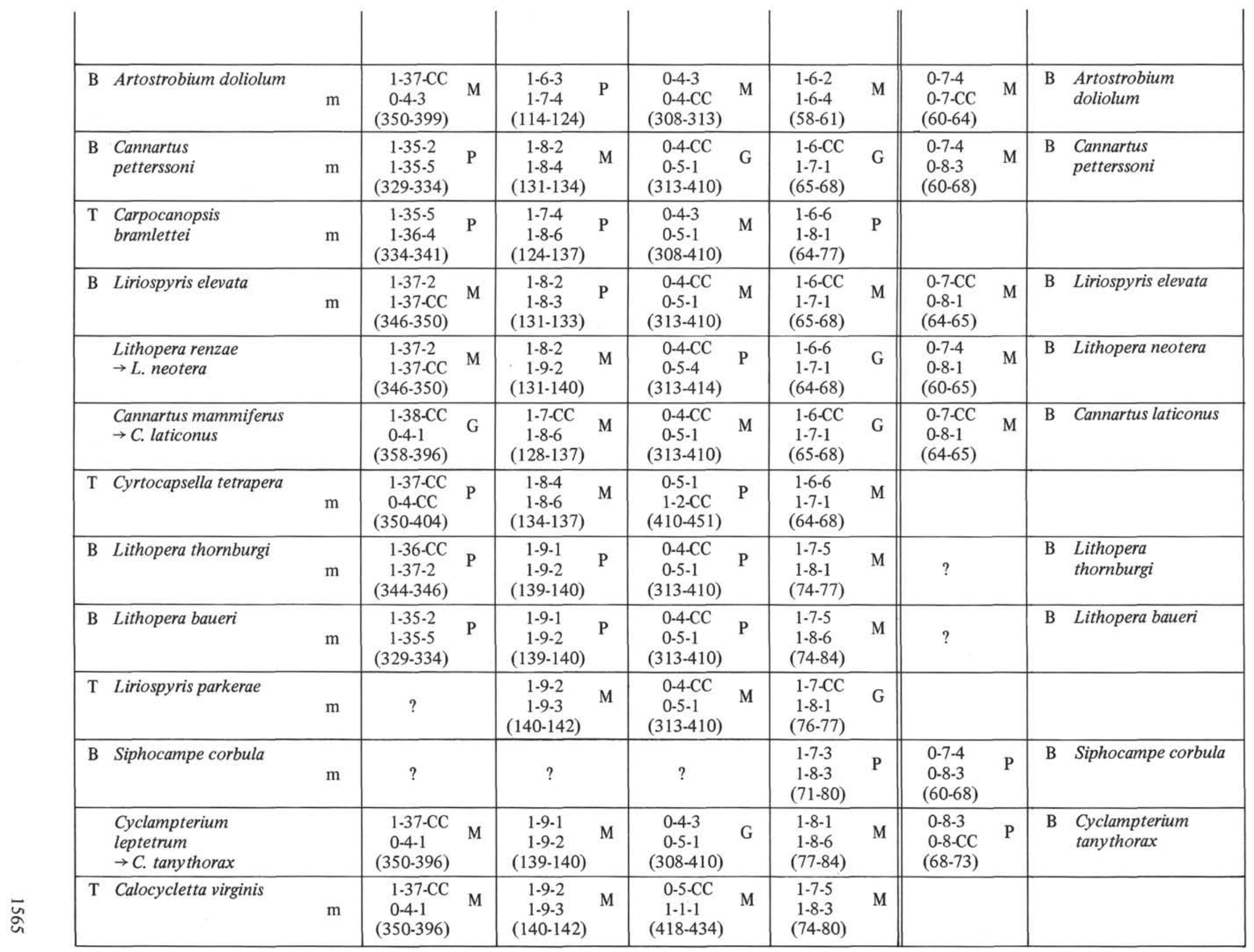


TABLE 6 - Continued

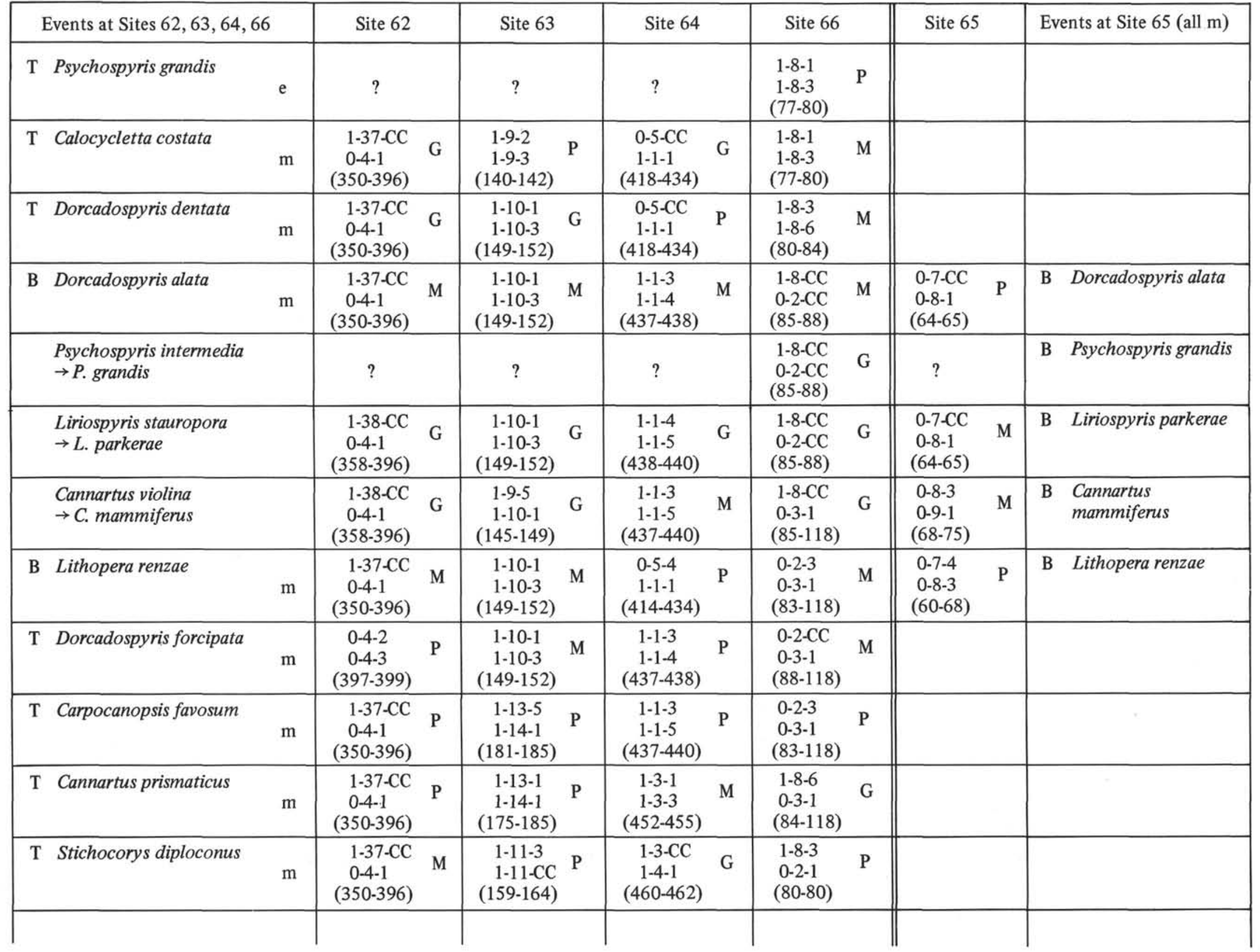




\begin{tabular}{|c|c|c|c|c|c|c|c|c|c|c|c|c|c|c|}
\hline $\mathrm{T}$ & $\begin{array}{l}\text { Carpocanopsis } \\
\text { cingulatum }\end{array}$ & $\mathrm{m}$ & $\begin{array}{c}1-37-2 \\
0-4-3 \\
(346-399) \\
\end{array}$ & G & $\begin{array}{c}1-12-\mathrm{CC} \\
1-13-1 \\
(174-175) \\
\end{array}$ & G & $\begin{array}{c}1-3-3 \\
1-4-3 \\
(455-465) \\
\end{array}$ & G & $\begin{array}{c}0-2-\mathrm{CC} \\
0-3-1 \\
(88-118)\end{array}$ & M & & & & \\
\hline B & $\begin{array}{l}\text { Carpocanopsis } \\
\text { cristatum }\end{array}$ & $\mathrm{m}$ & $\begin{array}{c}1-37-2 \\
0-4-3 \\
(346-399)\end{array}$ & M & $\begin{array}{c}1-13-3 \\
1-14-1 \\
(178-185)\end{array}$ & P & $\begin{array}{c}1-4-3 \\
1-5-1 \\
(465-471)\end{array}$ & $\mathrm{P}$ & $\begin{array}{l}0-2-\mathrm{CC} \\
0-3-1 \\
(88-118)\end{array}$ & M & $\begin{array}{c}0-8-5 \\
0-10-3 \\
(71-87)\end{array}$ & M & B & $\begin{array}{l}\text { Carpocanopsis } \\
\text { cristatum }\end{array}$ \\
\hline B & Calocycletta costata & $\mathrm{m}$ & $\begin{array}{c}0-4-\mathrm{CC} \\
0-5-2 \\
(404-492)\end{array}$ & G & $\begin{array}{c}1-13-C C \\
1-14-1 \\
(183-185)\end{array}$ & G & $\begin{array}{c}1-5-\mathrm{CC} \\
0-6-1 \\
(479-506)\end{array}$ & M & $\begin{array}{l}0-2-\mathrm{CC} \\
0-3-1 \\
(88-118)\end{array}$ & M & $\begin{array}{c}0-8-5 \\
0-9-1 \\
(71-75)\end{array}$ & G & B & $\begin{array}{l}\text { Calocycletta } \\
\text { costata }\end{array}$ \\
\hline$T$ & Lychnocanium bipes & $\mathrm{m}$ & $\begin{array}{c}0-4-6 \\
0-5-2 \\
(403-492) \\
\end{array}$ & M & $\begin{array}{c}1-14-1 \\
1-14-3 \\
(185-188) \\
\end{array}$ & M & $\begin{array}{c}1-5-1 \\
1-5-3 \\
(471-474) \\
\end{array}$ & M & $\begin{array}{l}0-2-\mathrm{CC} \\
0-3-1 \\
(88-118)\end{array}$ & G & & & & \\
\hline B & Stichocorys diploconus & $\mathrm{m}$ & $\begin{array}{c}0-4-C C \\
0-5-2 \\
(404-492)\end{array}$ & M & $\begin{array}{c}1-14-\mathrm{CC} \\
0-4-2 \\
(193-232)\end{array}$ & M & $\begin{array}{c}1-4-\mathrm{CC} \\
1-5-1 \\
(470-471)\end{array}$ & M & $\begin{array}{c}0-2-1 \\
1-8-6 \\
(80-84)\end{array}$ & $P$ & $\begin{array}{c}0-9-1 \\
0-9-3 \\
(75-78)\end{array}$ & M & B & $\begin{array}{l}\text { Stichocorys } \\
\text { diploconus }\end{array}$ \\
\hline & $\begin{array}{l}\text { Cannartus tubarius } \\
\rightarrow \text { C. violina }\end{array}$ & & $\begin{array}{c}0-4-\mathrm{CC} \\
0-5-2 \\
(404-492) \\
\end{array}$ & G & $\begin{array}{c}1-13-5 \\
1-14-5 \\
(181-191)\end{array}$ & M & $\begin{array}{c}1-5-1 \\
1-5-\mathrm{CC} \\
(471-479)\end{array}$ & M & $\begin{array}{c}1-8-\mathrm{CC} \\
0-3-1 \\
(85-118)\end{array}$ & M & $\begin{array}{c}0-10-3 \\
0-11-2 \\
(87-94)\end{array}$ & M & B & Cannartus violina \\
\hline$T$ & $\begin{array}{l}\text { Theocorys } \\
\text { spongoconum }\end{array}$ & $\mathrm{m}$ & $\begin{array}{c}0-4-6 \\
0-5-2 \\
(403-492)\end{array}$ & M & $\begin{array}{c}1-13-5 \\
1-14-3 \\
(181-188)\end{array}$ & $P$ & $\begin{array}{c}0-6-1 \\
0-6-4 \\
(506-510)\end{array}$ & $P$ & $?$ & & & & & \\
\hline B & Liriospyris stauropora & $\mathrm{m}$ & $\begin{array}{c}0-4-C C \\
0-5-2 \\
(404-492)\end{array}$ & G & $\begin{array}{c}1-14-\mathrm{CC} \\
0-4-1 \\
(193-231)\end{array}$ & M & $\begin{array}{c}1-5-\mathrm{CC} \\
0-6-1 \\
(479-506)\end{array}$ & G & $\begin{array}{l}0-2-\mathrm{CC} \\
0-3-1 \\
(88-118)\end{array}$ & G & $\begin{array}{c}0-8-\mathrm{CC} \\
0-9-1 \\
(73-75)\end{array}$ & M & B & $\begin{array}{l}\text { Liriospyris } \\
\text { stauropora }\end{array}$ \\
\hline $\mathrm{T}$ & Botryopyle sp. A & $\mathrm{m}$ & $\begin{array}{c}0-4-\mathrm{CC} \\
0-5-2 \\
(404-492)\end{array}$ & M & $\begin{array}{c}1-14-\mathrm{CC} \\
0-4-2 \\
(193-232)\end{array}$ & G & $\begin{array}{c}1-5-3 \\
0-6-1 \\
(474-506)\end{array}$ & $\mathrm{M}$ & $\begin{array}{l}0-2-3 \\
0-3-1 \\
(83-118)\end{array}$ & M & & & & \\
\hline
\end{tabular}


TABLE 6 - Continued

\begin{tabular}{|c|c|c|c|c|c|c|c|c|c|c|c|c|c|c|}
\hline \multicolumn{3}{|c|}{ Events at Sites 62, 63, 64, 66} & \multicolumn{2}{|l|}{ Site 62} & \multicolumn{2}{|l|}{ Site 63} & \multicolumn{2}{|l|}{ Site 64} & \multicolumn{2}{|l|}{ Site 66} & \multicolumn{2}{|l|}{ Site 65} & \multicolumn{2}{|c|}{ Events at Site 65 (all m) } \\
\hline & Carpocanopsis bramlettei & $\mathrm{m}$ & $\begin{array}{c}0-4-6 \\
0-5-4 \\
(403-495)\end{array}$ & G & $\begin{array}{c}1-14-1 \\
0-4-1 \\
(185-231)\end{array}$ & M & $\begin{array}{c}1-6-3 \\
0-7-1 \\
(569-611)\end{array}$ & $\mathrm{P}$ & $?$ & & $\begin{array}{c}0-8-5 \\
0-10-3 \\
(71-87)\end{array}$ & $\mathrm{P}$ & B & $\begin{array}{l}\text { Carpocanopsis } \\
\text { bramlettei }\end{array}$ \\
\hline B & Cannartus tubarius & $\mathrm{m}$ & $\begin{array}{c}0-4-6 \\
0-5-2 \\
(403-492)\end{array}$ & $P$ & $\begin{array}{c}0-4-1 \\
0-4-2 \\
(231-232)\end{array}$ & M & $\begin{array}{c}0-6-\mathrm{CC} \\
1-6-1 \\
(514-566)\end{array}$ & G & $\begin{array}{c}0-3-5 \\
0-3-C C \\
(124-126)\end{array}$ & $P$ & $\begin{array}{l}0-10-\mathrm{CC} \\
0-11-2 \\
(92-94)\end{array}$ & $\mathrm{P}$ & B & Cannartus tubarius \\
\hline & Stichocorys armata & $\mathrm{m}$ & ? & & $\begin{array}{c}0-4-2 \\
0-5-2 \\
(232-354)\end{array}$ & M & $\begin{array}{c}0-6-1 \\
1-6-1 \\
(506-566)\end{array}$ & $\mathrm{P}$ & $\begin{array}{c}0-2-3 \\
0-3-1 \\
(83-118)\end{array}$ & G & $\begin{array}{c}0-10-1 \\
0-10-3 \\
(84-87)\end{array}$ & M & B & Stichocorys armata \\
\hline & Theocyrtis annosa & $\mathrm{m}$ & $\begin{array}{c}0-4-\mathrm{CC} \\
0-5-2 \\
(404-492)\end{array}$ & M & $\begin{array}{c}0-4-\mathrm{CC} \\
0-5-1 \\
(239-353)\end{array}$ & G & $\begin{array}{c}1-6-3 \\
0-7-1 \\
(569-611)\end{array}$ & G & $\begin{array}{c}0-2-\mathrm{CC} \\
0-3-1 \\
(88-118)\end{array}$ & G & & & & \\
\hline B & $\begin{array}{l}\text { Stichocorys } \\
\text { delmontensis }\end{array}$ & $\mathrm{m}$ & $\begin{array}{l}\text { Below } \\
0-5-C C \\
(499)\end{array}$ & M & $\begin{array}{c}0-4-\mathrm{CC} \\
0-5-1 \\
(239-353)\end{array}$ & G & $\begin{array}{c}1-6-\mathrm{CC} \\
0-7-1 \\
(574-611)\end{array}$ & G & $\begin{array}{l}0-2-\mathrm{CC} \\
0-3-1 \\
(88-118)\end{array}$ & G & $\begin{array}{c}0-10-3 \\
0-11-2 \\
(87-94)\end{array}$ & M & B & $\begin{array}{l}\text { Stichocorys } \\
\text { delmontensis }\end{array}$ \\
\hline $\mathrm{T}$ & Dorcadospyris ateuchus & $\mathrm{m}$ & $\begin{array}{c}0-5-2 \\
0-5-3 \\
(492-494)\end{array}$ & $P$ & $\begin{array}{c}0-4-1 \\
0-4-2 \\
(231-232)\end{array}$ & M & $\begin{array}{c}0-7-\mathrm{CC} \\
1-7-1 \\
(619-662)\end{array}$ & $\mathrm{P}$ & $\begin{array}{c}0-3-3 \\
0-3-4 \\
(121-122)\end{array}$ & M & & & & \\
\hline B & $\begin{array}{l}\text { Carpocanopsis } \\
\text { favosum }\end{array}$ & $\mathrm{m}$ & $\begin{array}{c}0-4-6 \\
0-5-2 \\
(403-492)\end{array}$ & $P$ & $\begin{array}{c}0-4-2 \\
0-5-2 \\
(232-354)\end{array}$ & P & $\begin{array}{c}0-7-3 \\
1-7-3 \\
(614-665)\end{array}$ & M & $\begin{array}{c}0-3-5 \\
0-3-C C \\
(124-126)\end{array}$ & $\mathrm{P}$ & $\begin{array}{c}0-11-4 \\
0-12-5 \\
(97-108)\end{array}$ & $P$ & B & $\begin{array}{l}\text { Carpocanopsis } \\
\text { favosum }\end{array}$ \\
\hline B & Botryocyrtis spp. & $\mathrm{m}$ & $\begin{array}{c}\text { Below } \\
0-5-4 \\
(495)\end{array}$ & M & $\begin{array}{c}0-4-2 \\
0-4-\mathrm{CC} \\
(232-239)\end{array}$ & $\mathrm{P}$ & $\begin{array}{c}1-6-1 \\
1-6-3 \\
(566-569)\end{array}$ & $\mathrm{P}$ & $\begin{array}{c}\text { Below } \\
0-3-5 \\
(124)\end{array}$ & & $\begin{array}{c}0-12-1 \\
0-12-3 \\
(102-105)\end{array}$ & $P$ & B & Botryocyrtis spp. \\
\hline & Dorcadospyris papilio & $\mathrm{m}$ & $\begin{array}{l}\text { Below } \\
0-5-C C \\
(499)\end{array}$ & & $\begin{array}{c}0-5-2 \\
0-5-\mathrm{CC} \\
(354-361)\end{array}$ & $\mathbf{P}$ & $\begin{array}{c}0-7-\mathrm{CC} \\
1-7-1 \\
(619-662)\end{array}$ & $P$ & $\begin{array}{c}\text { Within } \\
0-3-1 \\
(118)\end{array}$ & $\mathrm{P}$ & & & & \\
\hline & Cyrtocapsella cornuta & $\mathrm{m}$ & $\begin{array}{l}\text { Below } \\
0-5-C C \\
(499)\end{array}$ & & $\begin{array}{c}0-4-\mathrm{CC} \\
0-5-2 \\
(239-354)\end{array}$ & M & $\begin{array}{c}0-7-\mathrm{CC} \\
1-7-1 \\
(619-662)\end{array}$ & G & $\begin{array}{c}0-3-1 \\
0-3-5 \\
(118-124)\end{array}$ & M & $\begin{array}{c}0-11-4 \\
0-12-1 \\
(97-102)\end{array}$ & G & B & $\begin{array}{l}\text { Cyrtocapsella } \\
\text { cornuta }\end{array}$ \\
\hline & Calocycletta virginis & $\mathrm{m}$ & $\begin{array}{l}\text { Below } \\
0-5-C C \\
(499)\end{array}$ & & $\begin{array}{c}0-4-\mathrm{CC} \\
0-5-1 \\
(239-353)\end{array}$ & G & $\begin{array}{c}0-7-\mathrm{CC} \\
1-7-1 \\
(619-662)\end{array}$ & $\mathrm{M}$ & $\begin{array}{c}0-3-3 \\
0-3-4 \\
(121-122)\end{array}$ & $P$ & $\begin{array}{c}0-11-\mathrm{CC} \\
0-12-1 \\
(101-102)\end{array}$ & M & B & $\begin{array}{l}\text { Calocycletta } \\
\text { virginis }\end{array}$ \\
\hline
\end{tabular}




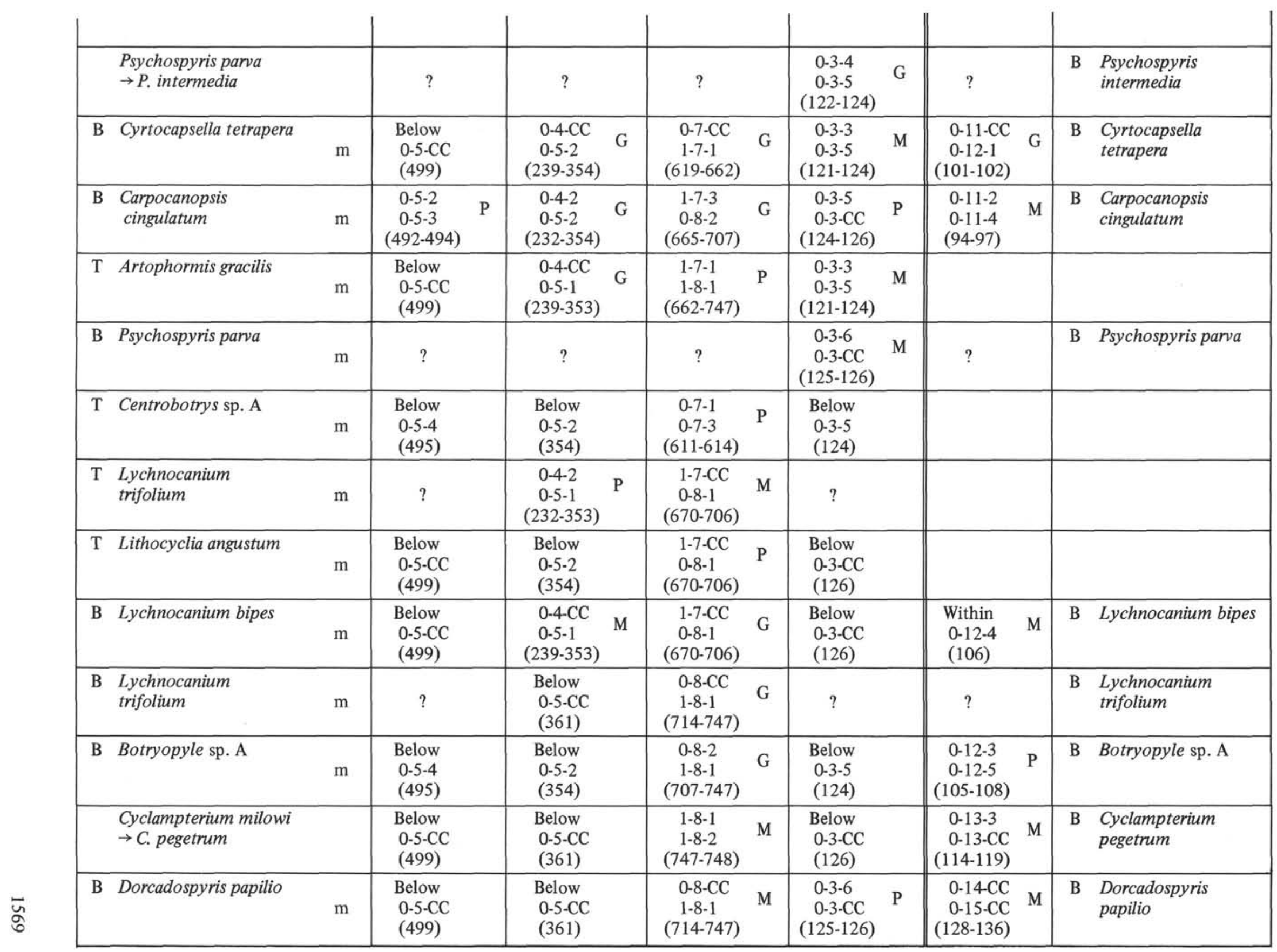


TABLE 6 - Continued

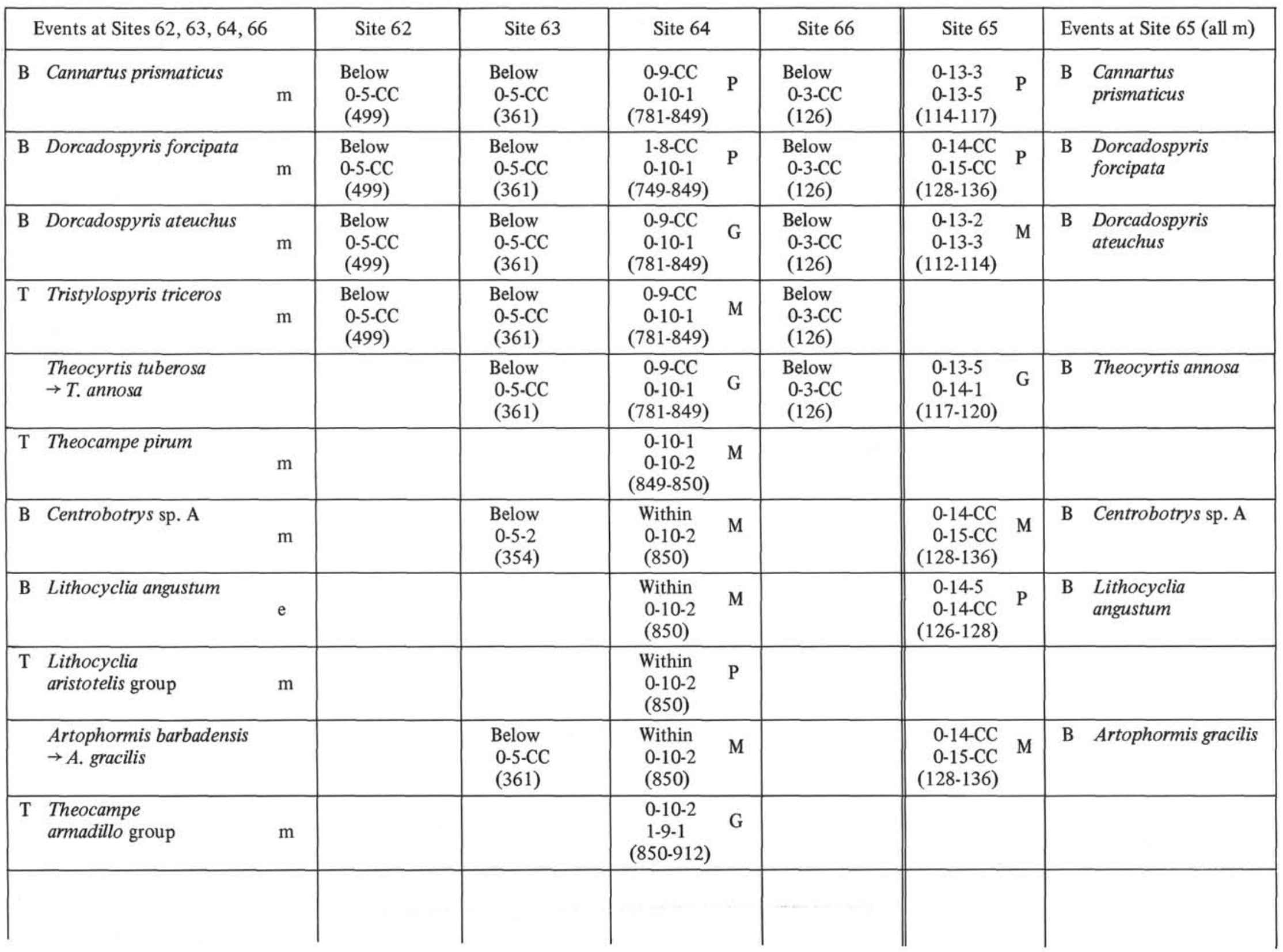




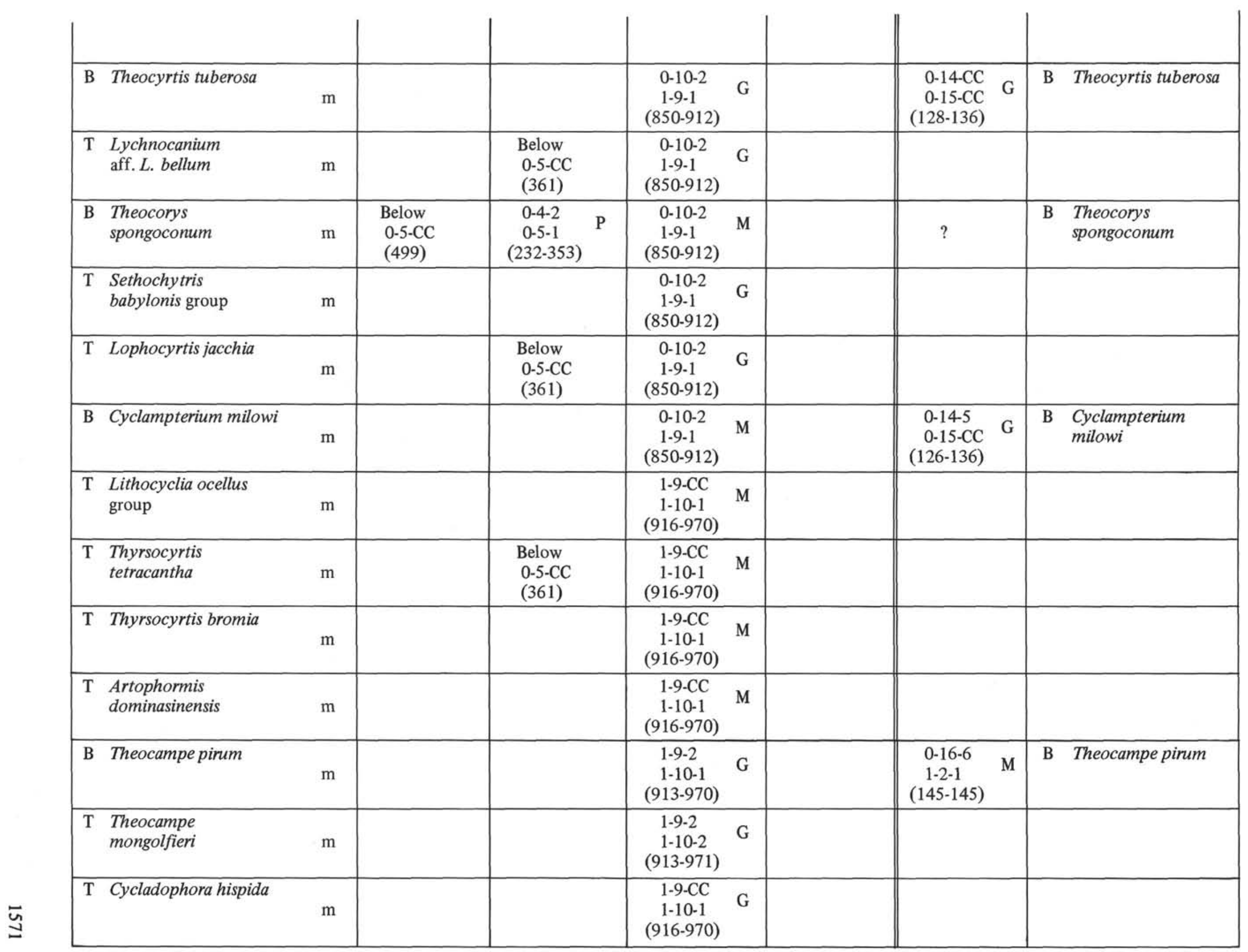


TABLE 6 - Continued

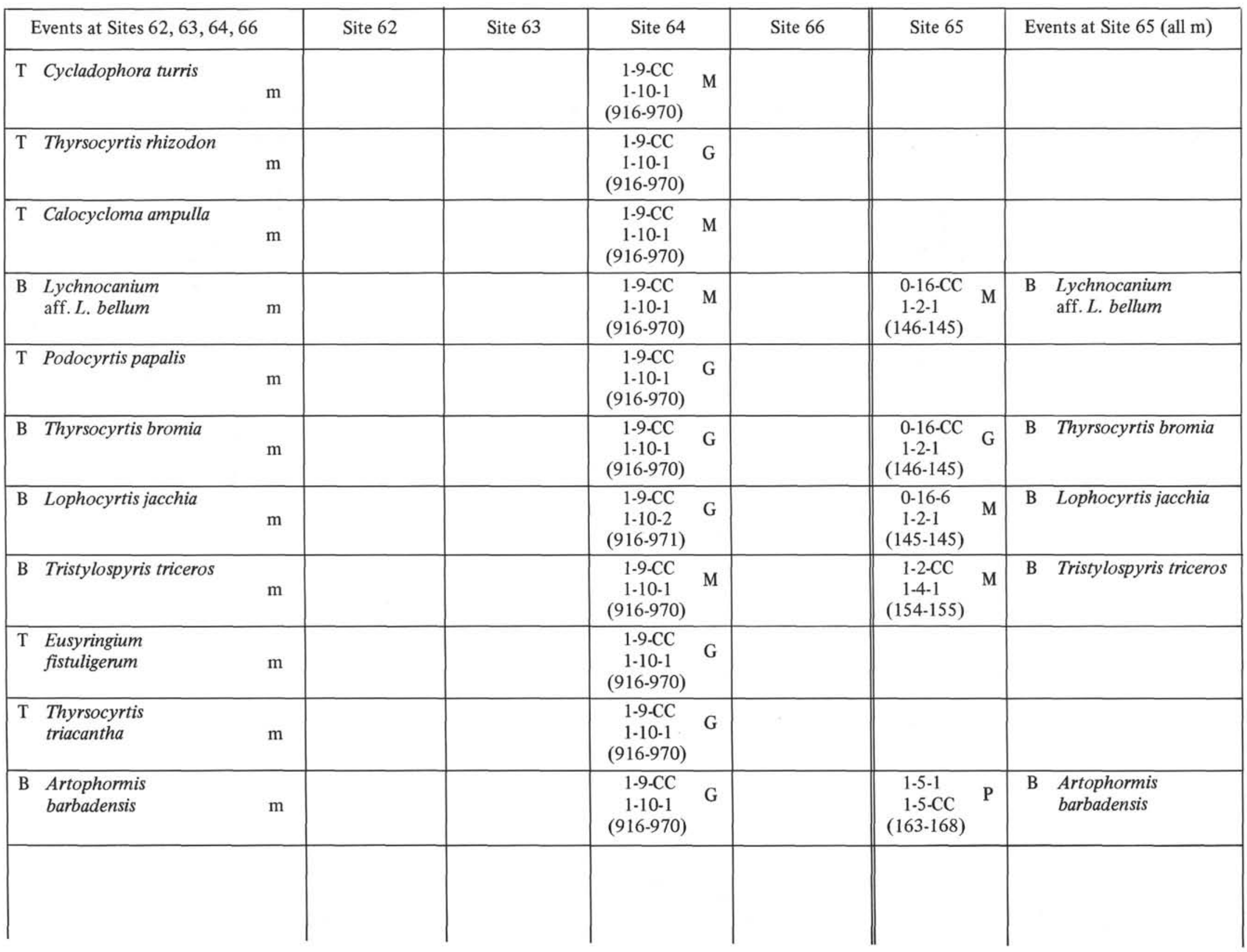




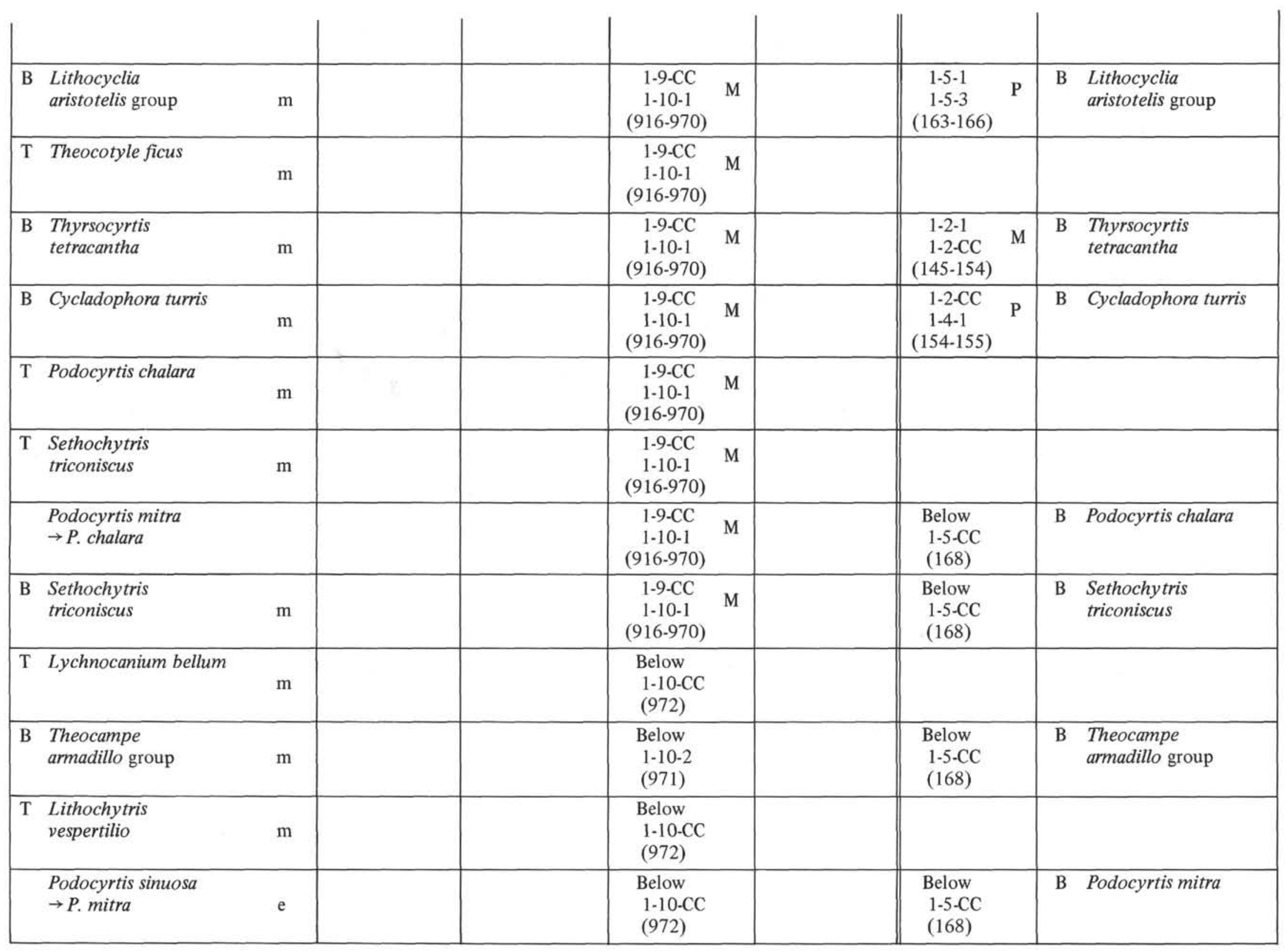




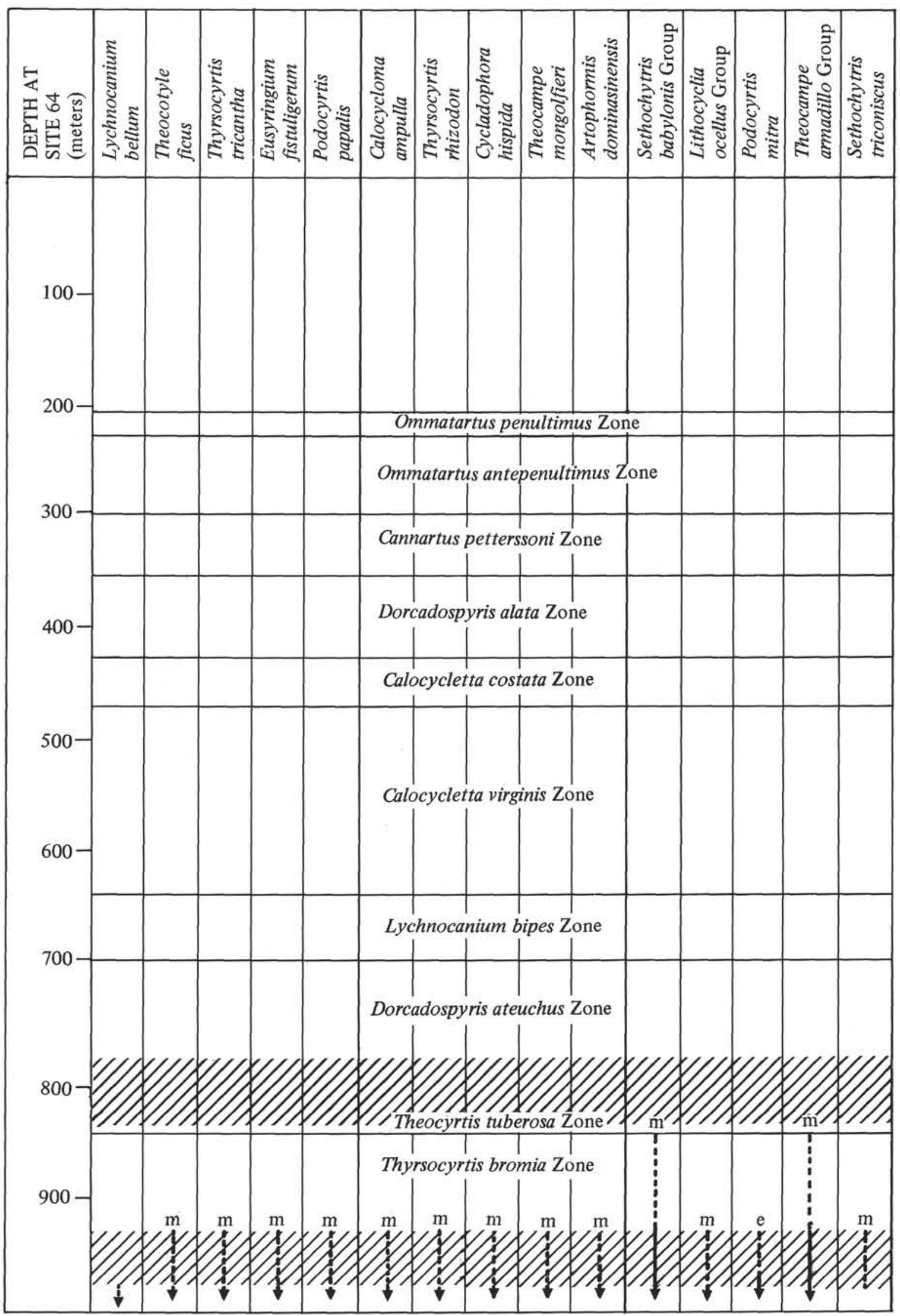

Figure 2. Radiolarian Ranges and Zones. 


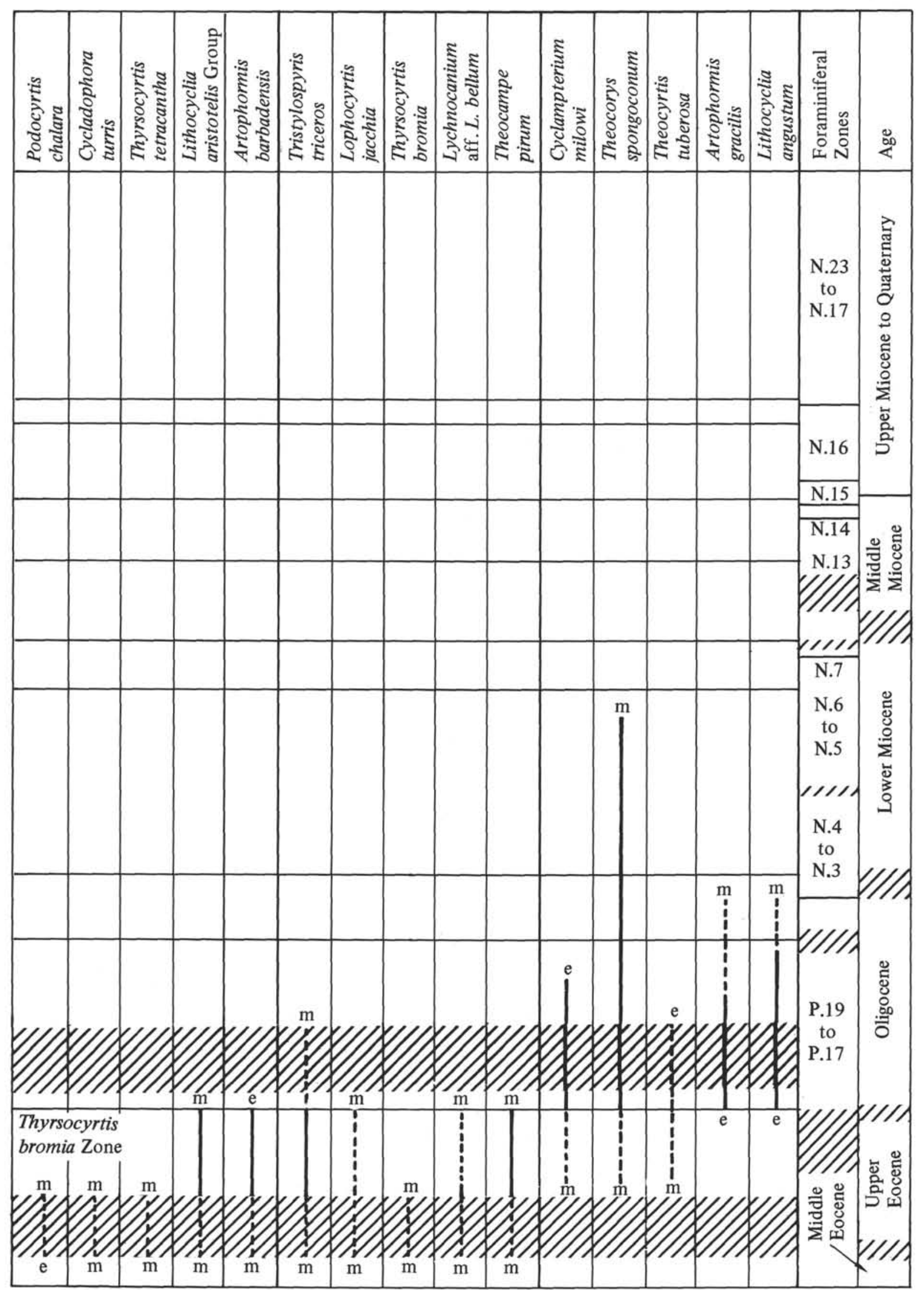

Figure 2. Continued. 


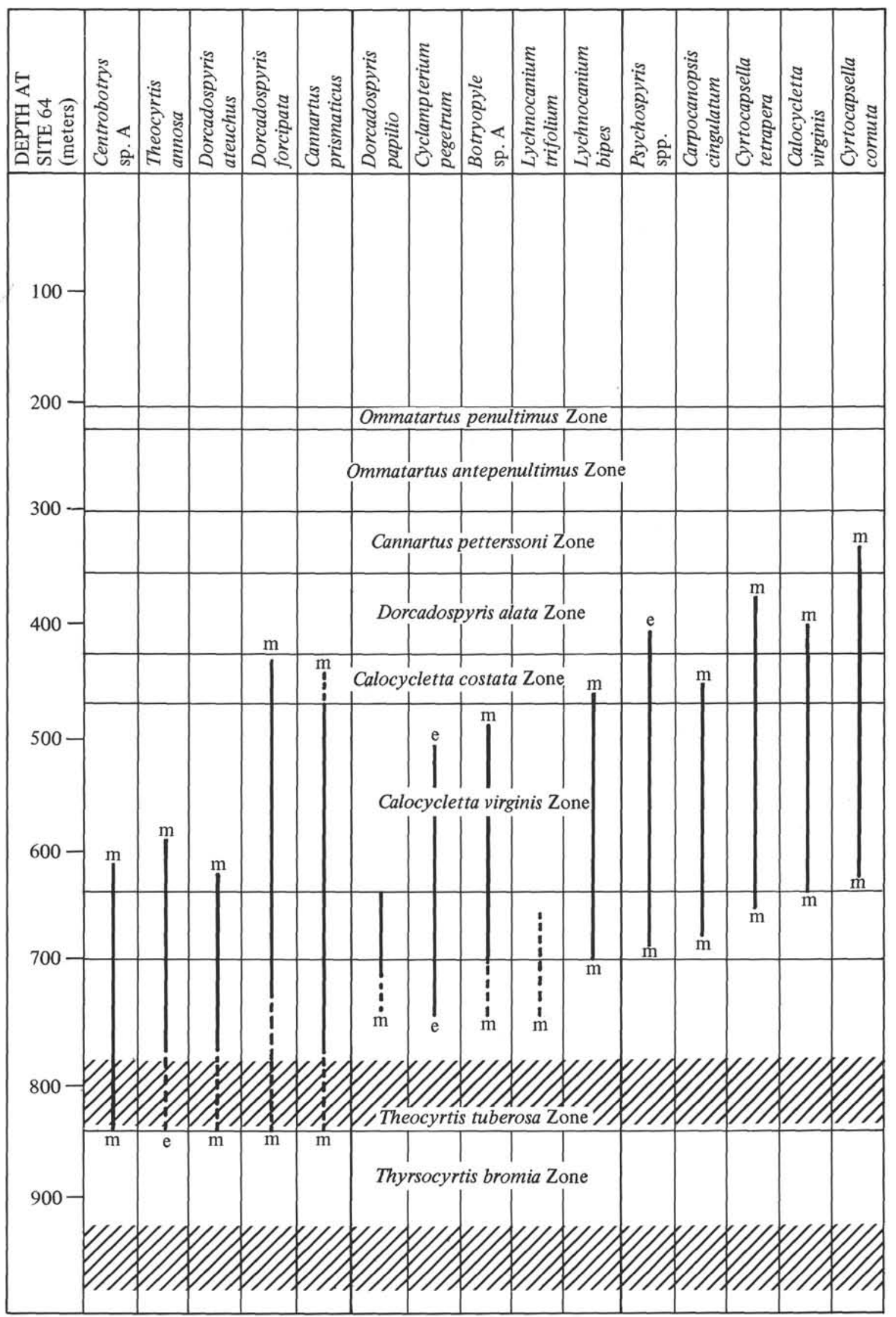

Figure 2. Continued. 


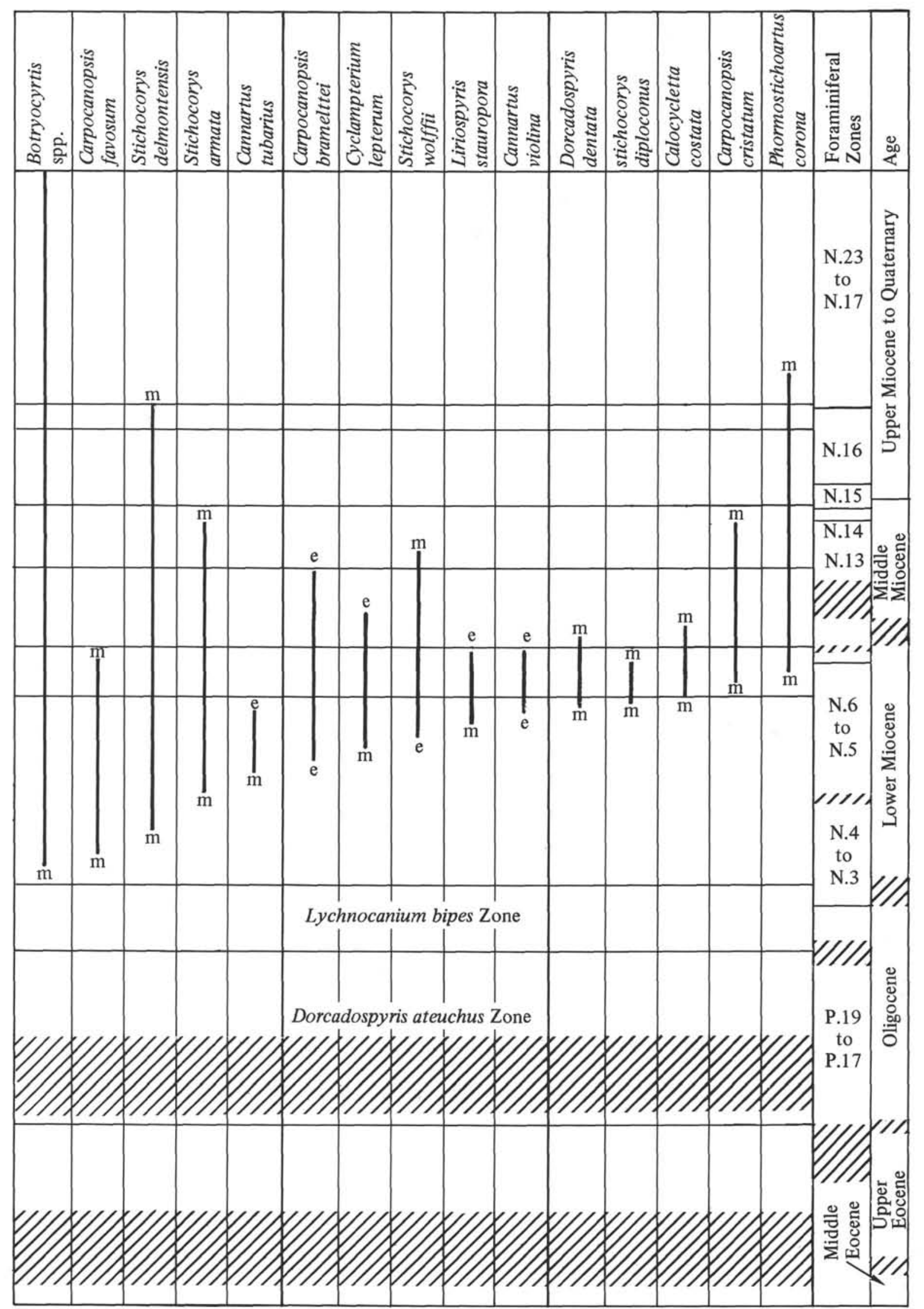

Figure 2. Continued. 


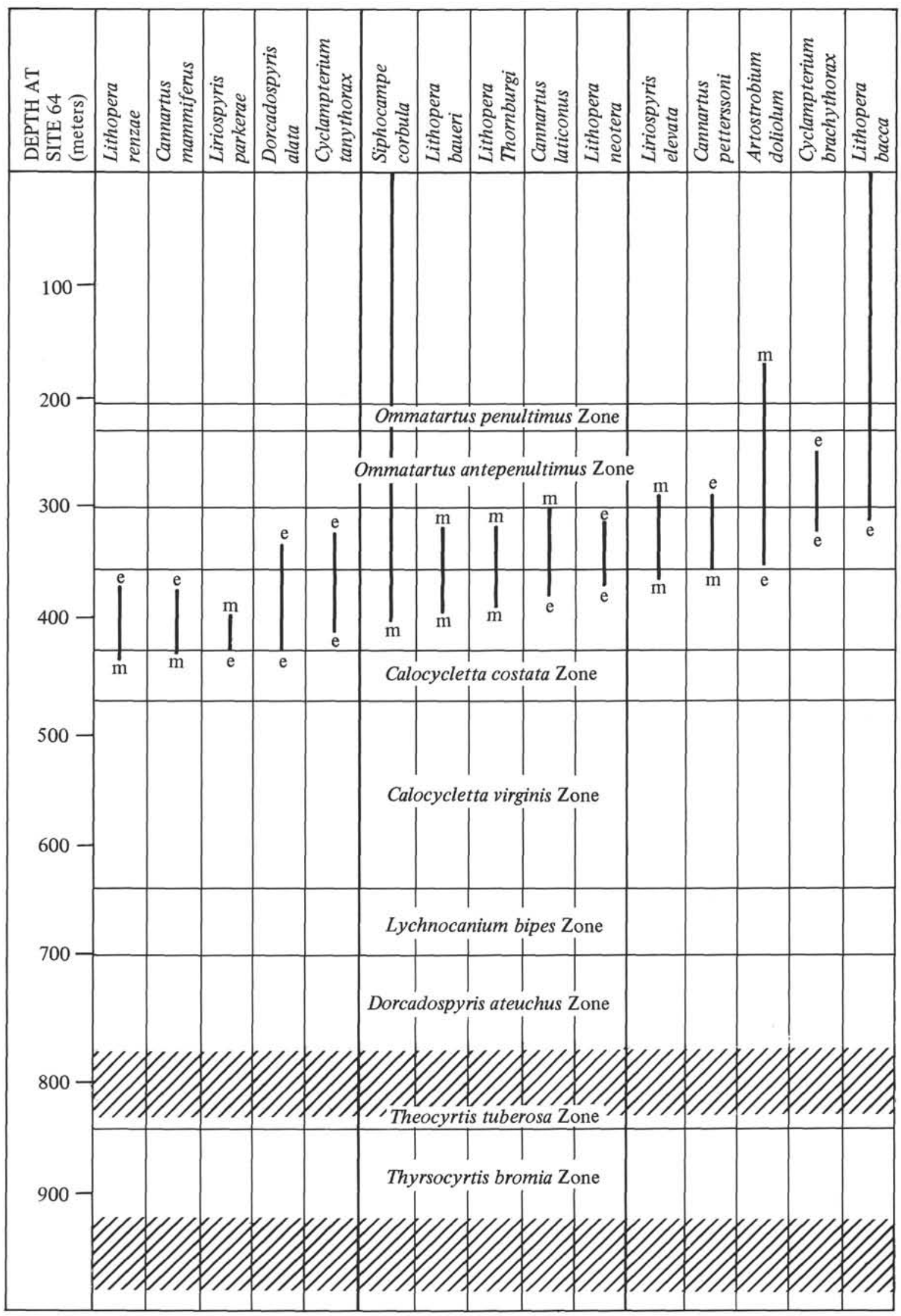

Figure 2. Continued. 


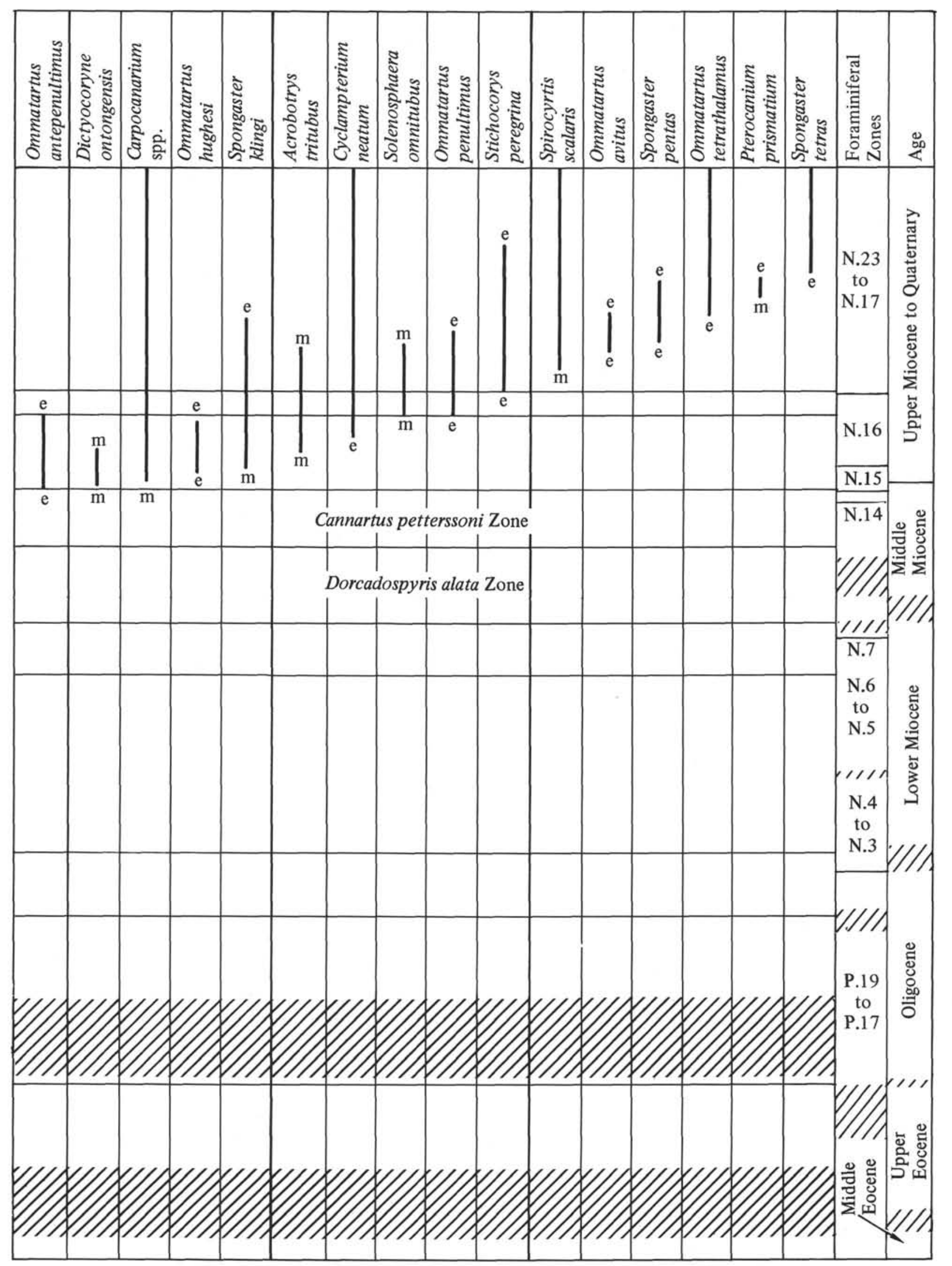

Figure 2. Continued. 
The transitions from Cannartus mammiferus to $C$. laticonus and from Lithopera renzae to $L$. neotera.

The earliest morphotypic appearance of Liriospyris elevata.

\section{Cannartus (?) petterssoni Zone:}

Base defined by the earliest evolutionary appearance of Cannartus (?) petterssoni, which is approximately synchronous with the latest occurrence of Carpocanopsis bramlettei. Events within this zone include:

The earliest morphotypic appearance of Artostrobium doliolum.

The latest occurrences of Stichocorys wolffii, Cyrtocapsella cornuta, Dorcadospyris alata and Stichocorys armata.

The transition from Cyclampterium tanythorax to $C$. brachythorax.

The latest occurrences of Lithopera baueri, L. thornburgi and Carpocanopsis cristatum.

The transition from Lithopera neotera to $L$. bacca.

\section{Ommatartus antepenultimus Zone:}

Base defined by the earliest evolutionary appearance of Ommatartus antepenultimus, which is approximately synchronous with the earliest morphotypic appearance of Dictyocoryne ontongensis. Events within this zone include:

The earliest morphotypic appearance of Carpocanarium spp.

The latest occurrence of Liriospyris elevata.

The transition from Cannartus (?) petterssoni to Ommatartus hughesi.

The earliest morphotypic appearances of Spongaster klingi and Acrobotrys tritubus.

The latest occurrence of Dictyocoryne ontongensis.

The transition from Cyclampterium brachythorax to C. neatum.

The latest occurrence of Ommatartus hughesi.

\section{Ommatartus penultimus Zone:}

Base defined by the earliest evolutionary appearance of Ommatartus penultimus, which is approximately synchronous with the earliest morphotypic appearance of Solenosphaera omnitubus. The top of this zone (coincident with the base of the Stichocorys peregrina Zone) is defined by the evolutionary transition from Stichocorys delmontensis to $S$. peregrina. The order of radiolarian events above this level cannot be described with confidence on the basis of the Leg 7 material.

\section{CORRELATIONS WITH EUROPE AND THE CARIBBEAN}

It is of practical interest to attempt to correlate European and Caribbean radiolarian assemblages with the sequence found in the western tropical Pacific, partly because the ages of some of those land-based localities are not well established by calcareous microfossils, and partly as a test of the geographic extent of the applicability of the biostratigraphic zonation developed above. Because the western Pacific sequences provide better representation of the Miocene and Oligocene than they do of the Eocene, we concentrate in this section on land-based localities of the former ages, and treat Eocene occurrences only briefly.

Results of these comparisons are summarized in Figure 3 , in which horizontal lines are omitted from the leftand right-hand columns because the correlations are only approximate.

\section{6a. European Neogene}

European Neogene samples suitable for this study are all from the Mediterranean region, and most were collected by the senior author with the help of R. Selli, G. Colom, G. Ruggieri and L. Montanari. Additional samples were provided by I. Premoli Silva. The localities of samples with radiolarian assemblages sufficiently diverse to permit an attempt at correlation with the western Pacific sequence are listed below, together with ages (in quotation marks) indicated by local geologists or the older literature.

WRE 67-76 to WRE 67-78. Three outcrops in very low road-banks near the church at Monte Calvo $\left(44.418^{\circ} \mathrm{N}\right.$, $\left.11.384^{\circ} \mathrm{E}\right)$, near Bologna, Italy. No. 76 is approximately 200 meters WSW of the church, no. 77 approximately 400 meters WSW of the church, and no. 78 approximately 450 meters W of the church. "Aquitanian or lowermost Langhian".

WRE 67-95 and WRE 67-96. Outcrops near the roadside chapel at il Monticciolo $\left(44.511^{\circ} \mathrm{N}, 10.773^{\circ} \mathrm{E}\right)$, near Montegibbio, S of Sassuolo, Italy. No. 95 is approximately 20 meters S of the chapel, and no. 96 approximately 10 meters $\mathrm{S}$ of the chapel.

WRE 67-99 and WRE 67-100. Near the farm-house Bergonzano $\left(44.619^{\circ} \mathrm{N}, 10.469^{\circ} \mathrm{E}\right), \mathrm{S}$ of Quattro Castella, Italy. No. 99 is from a small pit about 30 meters E of the farm-house, and no. 100 from a roadcut approximately 350 meters further ENE. "Langhian".

WRE 67-106. Near Ca' de Rossi, approximately 2 kilometers ESE of Salsomaggiore, Italy. In a roadcut, at fork $\left(44.811^{\circ} \mathrm{N}, 10.000^{\circ} \mathrm{E}\right)$ of the roads that lead to Ca'Lombasini and to Tabiano. "Upper Langhian to Lower Elveziano". 


\begin{tabular}{|c|c|c|}
\hline European Localities & $\begin{array}{l}\text { Middle Eocene to Pliocene } \\
\text { Radiolarian Zones }\end{array}$ & Caribbean Localities \\
\hline \multirow{9}{*}{$\left.\begin{array}{l}\text { Casalino and Monte Calvo, N. Italy } \\
\text { Montegibbio, Bergonzano, Mar- } \\
\text { morita and Salsomaggiore, N. Italy }\end{array}\right\}$} & $\begin{array}{l}\text { Pterocanium } \\
\text { prismatium }\end{array}$ & \multirow{20}{*}{$\begin{array}{l}\text { St. Mark's Church, Barbados } \\
\text { Hermitage Quar. and Philippine Rd., } \\
\text { Trinidad } \\
\text { Golconda Rwy. Stn., Trinidad }\end{array}$} \\
\hline & $\begin{array}{l}\text { Spongaster } \\
\text { pentas }\end{array}$ & \\
\hline & $\begin{array}{l}\text { Stichocorys } \\
\text { peregrina }\end{array}$ & \\
\hline & $\begin{array}{l}\text { Ommatartus } \\
\text { penultimus }\end{array}$ & \\
\hline & $\begin{array}{l}\text { Ommartartus } \\
\text { antepenultimus }\end{array}$ & \\
\hline & $\begin{array}{l}\text { Cannartus } \\
\text { petterssoni }\end{array}$ & \\
\hline & $\begin{array}{l}\text { Dorcadospyris } \\
\text { alata }\end{array}$ & \\
\hline & $\begin{array}{l}\text { Calocycletta } \\
\text { costata }\end{array}$ & \\
\hline & $\begin{array}{l}\text { Calocycletta } \\
\text { virginis }\end{array}$ & \\
\hline \multirow{11}{*}{ Tel Hesi and Beit Jibrin, Israel } & $\begin{array}{l}\text { Lychnocanium } \\
\text { bipes }\end{array}$ & \\
\hline & $\begin{array}{l}\text { Dorcadospyris } \\
\text { ateuchus }\end{array}$ & \\
\hline & $\begin{array}{l}\text { Theocyrtis } \\
\text { tuberosa }\end{array}$ & \\
\hline & $\begin{array}{l}\text { Thyrsocyrtis } \\
\text { bromia }\end{array}$ & \\
\hline & $\begin{array}{l}\text { Thyrsocyrtis } \\
\text { tetracantha }\end{array}$ & \\
\hline & $\begin{array}{l}\text { Unzoned interval with } \\
\text { Podocyrtis goetheana }\end{array}$ & \\
\hline & $\begin{array}{l}\text { Podocyrtis } \\
\text { chalara }\end{array}$ & \\
\hline & $\begin{array}{l}\text { Podocyrtis } \\
\text { mitra }\end{array}$ & \\
\hline & $\begin{array}{l}\text { Podocyrtis } \\
\text { ampla }\end{array}$ & \\
\hline & $\begin{array}{l}\text { Thyrsocyrtis } \\
\text { triacantha }\end{array}$ & \\
\hline & $\begin{array}{l}\text { Theocampe } \\
\text { mongolfieri }\end{array}$ & \\
\hline
\end{tabular}

Figure 3. European and Caribbean correlations. 
WRE 67-107. Roadcut at Ca' Lombasini $\left(44.810^{\circ} \mathrm{N}\right.$, $10.004^{\circ} \mathrm{E}$ ), near Salsomaggiore, Italy. "Upper Langhian to Lower Elveziano".

WRE 67-112. Roadcut at Marmorito $\left(45.069^{\circ} \mathrm{N}, 8.020^{\circ}\right.$ E), NE of Castelnuovo Don Bosco, Italy. "Elveziano".

Three samples from the low cliff "La Mirada" at Muro, Mallorca. Samples Nos. 1-3 of WRR 1963. "AquitanianBurdigalian" of Colom (1952).

Premoli Silva sample C.9 from the Casalino section, Vercelli, Nth. Italy. "Foraminiferal zone N5/6".

AGIP locality no. 6509, between Bagni di Tabiano and C. dei Bassi, approximately 450 meters SE of the point of origin of the road that leads from the SalsomaggioreFidenza-Parma road to Bagni di Tabiano, Nth. Italy. Tabianian sample from Maria Chierici via F. L. Parker.

Table 7 shows the species identified in the Mediterranean Neogene samples, and the radiolarian evidence is used as a basis for arranging the samples in five groups which are believed to be progressively younger upward in the table. The oldest sample is apparently in the Lychnocanium bipes Zone, the next group of six in approximately the early Calocycletta virginis Zone, the following four in the late $C$. virginis or $C$. costata Zone, the three Mallorcan samples in the early Dorcadospyris alata Zone, and the youngest one apparently in the Stichocorys peregrina Zone. Comparison of Table 7 with the middle part of Figure 2 shows that a surprisingly high proportion of the radiolarians which are stratigraphically useful in the tropical Pacific occur also in the Mediterranean region. However, the Mediterranean occurrences are sparse and sporadic, so that it is generally difficult to make correlations to within one radiolarian zone.

For some species, the Mediterranean specimens are identical with those from the Pacific, but within other species there are morphological differences as indicated in the following comments:

Cannartus sp. of the type illustrated to the synchronopticon, Plate 2B, Figures 9 and 10, is rather common in many of the Italian samples.

Doryphacus sp. In Italian samples at the upper limit of the range of Lithocyclia angustum, we have found specimens of Doryphacus sp. with the spin latticed (Plate 4, Figure 4), which may be related to the Dorydruppa sp. or Doryprunum sp. of Hole 62.0, Core 5 (Plate 4, Figure 3), as described in the discussion of the subfamily Artiscinae. That core is near the boundary between the Calocycletta virginis and Lychnocanium bipes Zones, and thus of about the same age as the Italian samples with Doryphacus sp.
Dorcadospyris sp. aff. D. dentata. Specimens in the Mallorcan assemblages (Plate 5, Figure 3) lack an apical horn, and have a small cephalis and feet approaching the wide divergence characteristic of $D$. alata.

Dorcadospyris simplex. Specimens in the Italian assemblages commonly have several smaller feet in addition to the two larger ones (Plate 5, Figure 2).

Artophormis gracilis. The upper three segments and apical horn of the Italian specimens (Plate 6, Figure 7) are similar to those of tropical Pacific and Caribbean specimens, but the fourth segment is different. In many specimens, downwardly-directed spines arise from the distal part of the third segment, and subsequently join the fourth segment which has rather small pores and an inconstant shape.

Cyclampterium (?) pegetrum. Specimens in the older Italian assemblages commonly have short cylindroconical feet which are slightly latticed proximally. They thus resemble early representatives of the species, close to $C$. (?) milowi.

Lithopera renzae. Specimens in the Mallorcan material are somewhat larger than usual. They are accompanied by a form (Plate 7, Figure 15) in which an additional internal constriction subdivides the large segment, so that the skeleton resembles a Stichocorys diploconus with a closed, obtusely-rounded base.

Stichocorys peregrina. The third segment of the Italian specimens (Plate 8, Figure 5) is not quite as neatly conical as in Pacific specimens, but in other respects they are typical.

Carpocanopsis cingulatum. The third segment of the Italian specimens is generally somewhat smaller and not as robust as that of Pacific specimens.

Calocycletta. In the Mediterranean assemblages, the few observed specimens of $C$. costata are not very pronouncedly costate, and the feet of $C$. virginis tend to be short and triangular rather than long and truncate.

\section{6b. European Eocene}

European samples containing Eocene radiolarian assemblages comparable with those of the tropics include two samples from Israel provided by Zeev Reiss, and one collected in Italy by M. N. Bramlette, listed below.

Geological Institute of Israel sample no. 1273-D32, from Tel Hesi, Israel, contains Phormocyrtis striata, Sethochytris babylonis group, Podocyrtis ampla, $P$. sinuosa and Theocampe mongolfieri, and thus belongs in the Podocyrtis ampla Zone. 
Geological Institute of Israel sample no. 2329-At, from Beit Jibrin, Israel, contains Lithapium (?) anoectum, Lithocyclia ocellus group, Cycladophora hispida, Eusyringium lagena (?), Theocorys anapographa, Thyrsocyrtis triacantha, Podocyrtis ampla, $P$. diamesa, $P$. papalis and $P$. sinuosa, and thus also belongs in the Podocyrtis ampla Zone.

A sample collected by M. N. Bramlette from the highest exposure $\mathrm{N}$ (approximately 0.5 kilometer $\mathrm{N}$ ) of Ponte dell' Olio on Torrente Nure, about 20 kilometers S of Piacenza, Italy, contains members of the Lithocyclia ocellus group, Lithocampium sp. with quincuncially arranged pores on the third segment and Phormocyrtis striata, and is apparently Lower Eocene in age.

\section{6c. Caribbean Neogene}

Caribbean Neogene radiolarian assemblages are known to have much in common with those of the tropical Pacific (Riedel, 1959b; Riedel and Sanfilippo, in press, footnotes to Figure 3), and Table 8 presents detailed information which permits rather precise correlations with the western Pacific sequence. Most of the samples (listed below) on which the tabulation is based were collected during the Fourth Caribbean Geological Congress in 1965 (Saunders and Cater, 1968; Saunders, 1968), but much of our earlier work on Caribbean Neogene radiolarians was based on samples generously provided by H. H. Renz, Paul Brönnimann, J. B. Saunders and H. M. Bolli.

TTOC 178888. Near Retrench trigonometrical station, Golconda Estate, Trinidad. Co-locality of the Globigerinatella insueta Zone (Bolli, 1957a, p. 101; Bramlette and Wilcoxon, 1967).

WRTR 10. Philippine Road, Trinidad. Radiolarian-rich facies of the Globorotalia fohsi barisanensis Zone (Stop 6 of Saunders and Cater, 1968). Approximately Bolli locality no. 200.

WRTR 11, High and Low, Hermitage Quarry, on the W side of the road leading from Hermitage Village to Ally's Creek about 1200 feet NW from the road junction in the village, south Trinidad. Type locality of the Globorotalia fohsi barisanensis Zone. Locality no. 202 of Bolli (1957 a, p. 101). WRTR 11 High is from approximately 1 meter higher in the quarry than WRTR 11 Low.

WRTR 23. Very near Golconda Railway Station, across the hill from the Retrench trigonometrical station. Kugler locality no. 9391 (Stop 19 of Saunders and Cater, 1968).

WRTR 36, 37 and 38. Exposures of Conset Marl near St. Mark's Church, Barbados (Stop 8 of Saunders,
1968). WRTR 36 is equivalent to Saunders' locality JS 1646, and WRTR 37 and 38 approximately equivalent to JS 1647.

The three samples from the Conset Marl contain a few reworked Eocene forms, but this contamination does not prevent assignment of the assemblages to radiolarian zones. In Table 8 the samples are arranged as nearly as possible in stratigraphic order, and the two oldest samples (from the Globigerinatella insueta foraminiferal zone) are seen to belong in the Calocycletta costata Zone, while the six younger ones (from the Globorotalia fohsi barisanensis foraminiferal zone) belong in Dorcadospyris alata Zone.

\section{6d. Caribbean Eocene}

Of the Caribbean Eocene samples presently available, many from the Oceanic Formation of Barbados and the Universidad Formation of Cuba contain wellpreserved radiolarian assemblages, and several from the Navet Formation of Trinidad contain poorly preserved radiolarians (often calcitized).

In our chapter on the radiolarians collected during Leg 4 of the DSDP, we implied that the Eocene radiolarianbearing sediments of the Oceanic Formation at Bath, Barbados, were all included in the Thyrsocyrtis tetracantha and T. bromia Zones. The range-chart (Riedel and Sanfilippo, in press, text-figure 3) was based on a series of samples kindly provided to $\mathrm{M}$. N. Bramlette by W. F.-Auer in 1953. However, examination of additional samples indicates that, although many of the radiolarian localities of the Oceanic Formation belong in these tow zones, there are other localities that extend well down into the Middle Eocene (Podocyrtis ampla Zone at least).

Three of Senn's samples (S.781, 888 and 893) collected at Bath and reported on by Beckmann (1953) contain radiolarian assemblages older than the Thyrsocyrtis tetracantha Zone. The assemblages in S.781 and S.888 include members of the Lithocyclia aristotelis group, Eusyringium fistuligerum, Podocyrtis chalara, $P$. goetheana and $P$. mitra, and lack Thyrsocyrtis tetracantha, and are thus assignable to the Podocyrtis chalara Zone or to the unzoned interval with $P$. goetheana. S.898 contains most of the species listed in the two samples above, but lacks Podocyrtis goetheana and members of the Lithocyclia aristotelis group, and is thus in the Podocyrtis chalara Zone.

A number of samples older than the Thyrsocyrtis tetracantha Zone were collected by the senior author during the Barbados field trip conducted by J. B. Saunders in connection with the Fourth Caribbean Geological Conference (Saunders, 1968). The oldest of several samples collected at Gay's Cove (sample WRTR 53 , approximately the same as Saunders' locality JS 
TABLE 7

Radiolarians in Mediterranean Neogene

(*indicates samples in which Doryphacus sp.

Accompanies Lithocyclia angustum)

\begin{tabular}{|c|c|c|c|c|c|c|c|c|c|c|c|c|c|c|c|c|c|c|c|c|c|c|c|}
\hline Samples & 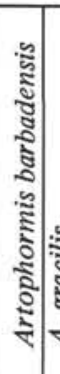 & 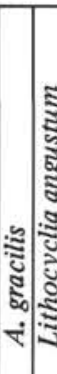 & 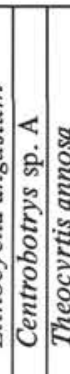 & 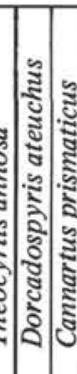 & 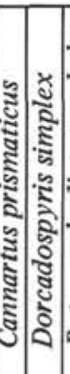 & 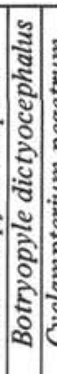 & 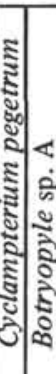 & 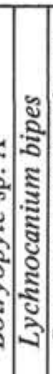 & 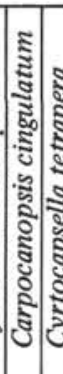 & 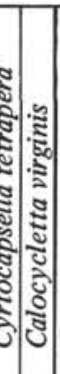 & 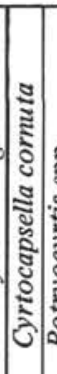 & 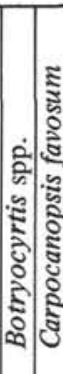 & 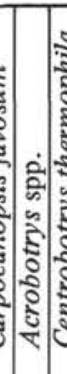 & 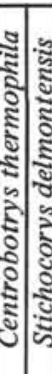 & 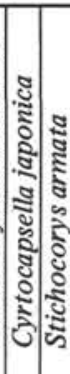 & 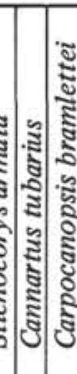 & : & 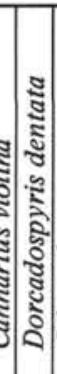 & 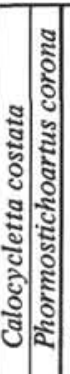 & 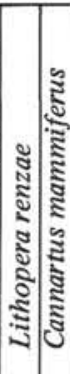 & 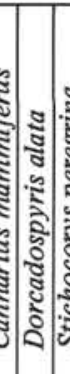 & 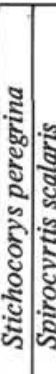 & 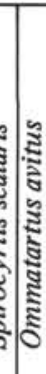 \\
\hline Tabianian 6509 & & & & & & & & & & & & & & & & & & & & & & $\mathrm{~F}+$ & $\mathrm{R}$ \\
\hline $\begin{array}{l}\text { Mallorca } 1 \\
\text { Mallorca } 2 \\
\text { Mallorca } 3 \\
\end{array}$ & & & & & $\begin{array}{l}+ \\
- \\
+\end{array}$ & + & + & $\begin{array}{l}- \\
+ \\
+ \\
\end{array}$ & $+\begin{array}{l}\mathrm{F} \\
\mathrm{C} \\
\mathrm{F}\end{array}$ & \begin{tabular}{l|l}
+ \\
$\mathrm{C}$ \\
$\mathrm{C}$ \\
+
\end{tabular} & \begin{tabular}{l|l}
$\mathrm{R}$ & $\mathrm{F}$ \\
$\mathrm{R}$ & \\
$\mathrm{R}$ & $\mathrm{F}$ \\
\end{tabular} & & & & \begin{tabular}{r|l}
$\mathrm{R}$ & $\mathrm{F}$ \\
+ & $\mathrm{F}$ \\
+ & $\mathrm{R}$ \\
\end{tabular} & & $\begin{array}{l}+ \\
+ \\
+ \\
+ \\
+ \\
+\end{array}$ & $\begin{array}{l}\mathrm{R} \\
\mathrm{R} \\
\mathrm{R}\end{array}$ & \begin{tabular}{l|l|} 
& \\
+ & $R$ \\
- & $R$ \\
\end{tabular} & \begin{tabular}{|l|l}
$R$ & $R$ \\
$R$ & $R$ \\
$R$ & $R$ \\
\end{tabular} & $\begin{array}{l}? \\
+ \\
+\end{array}$ & & \\
\hline $\begin{array}{l}\text { Casalino, Silva C.9 } \\
\text { Monte Calvo, WRE } 67-76 \\
\text { Monte Calvo, WRE } 67-77 \\
\text { Monte Calvo, WRE 67-78 }\end{array}$ & & - & & & $-\begin{array}{l}- \\
- \\
-\end{array}$ & \begin{tabular}{|l|l} 
& \\
$\mathrm{R}$ & - \\
+ \\
$\mathrm{R}$
\end{tabular} & $\begin{array}{l}+ \\
+ \\
+ \\
+ \\
- \\
+\end{array}$ & - & \begin{tabular}{|l|l} 
& $F$ \\
$R$ & $C$ \\
+ & $C$ \\
$R$ & $C$ \\
\end{tabular} & $\begin{array}{ll} & - \\
c & - \\
c & - \\
c & \end{array}$ & $\begin{array}{lll} & \mathrm{F} \\
\mathrm{R} & - \\
- & - \\
- & -\end{array}$ & $\begin{array}{l}\mathrm{R} \\
- \\
- \\
-\end{array}$ & & -1 & \begin{tabular}{|l|l}
$\mathrm{R}$ & $?$ \\
$\mathrm{R}$ & $\mathrm{R}$ \\
$\mathrm{F}$ & - \\
$\mathrm{F}$ & - \\
\end{tabular} & $\begin{array}{l}+ \\
++ \\
+ \\
+-\end{array}$ & 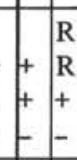 & & $\mathrm{R}$ & & & & \\
\hline $\begin{array}{l}\text { Montegibbio, WRE 67-95 } \\
\text { Montegibbio, WRE 67-96 } \\
\text { Bergonzano, WRE 67-99 } \\
\text { Bergonzano, WRE 67-100 } \\
\text { Marmorito, WRE 67-112 } \\
\text { Salsomaggiore, WRE } 67-107\end{array}$ & & \begin{tabular}{l|l}
+ & $*$ \\
- & $*$ \\
+ & $*$
\end{tabular} & -- & $\begin{array}{c}- \\
- \\
- \\
- \\
- \\
+ \\
+ \\
+\end{array}$ & $\begin{array}{l}- \\
R \\
+ \\
R \\
+ \\
+ \\
+ \\
+ \\
+ \\
+\end{array}$ & \begin{tabular}{l|l}
$\mathrm{R}$ & \\
$\mathrm{R}$ & \\
$\mathrm{R}$ & \\
$\mathrm{R}$ & - \\
+ & - \\
$\mathrm{R}$ & -
\end{tabular} & $\begin{array}{ll}+ & + \\
- & - \\
+ & - \\
- & \mathrm{R} \\
+ & + \\
+ & -\end{array}$ & $\begin{array}{c}\mathrm{R} \\
\mathrm{R} \\
+ \\
\mathrm{R} \\
\mathrm{R} \\
+ \\
+\end{array}$ & $\begin{aligned}- & R \\
+ & F \\
+ & R \\
- & C \\
+ & C \\
+ & F \\
+ & F\end{aligned}$ & \begin{tabular}{l|l}
$R$ & \\
$R$ & - \\
$c$ & - \\
$c$ & -
\end{tabular} & {$\left[\begin{array}{l}\mathrm{N} \\
+ \\
\mathrm{F} \\
\mathrm{R}\end{array}\right.$} & + & $+\mathrm{F}$ & & & & & & & & & & \\
\hline Salsomaggiore, WRE 67-106 & - - & -+ & & $+?$ & $?-1$ & $\mathrm{R} \mid+$ & & & & & & & & & & & & & & & & & \\
\hline
\end{tabular}

TABLE 8

Radiolarians in Neogene of Trinidad and Barbados

\begin{tabular}{|c|c|c|c|c|c|c|c|c|c|c|c|c|c|c|c|c|c|c|c|c|c|c|c|c|c|c|c|}
\hline imples & 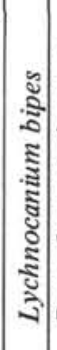 & 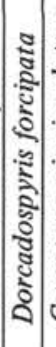 & 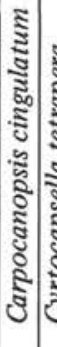 & 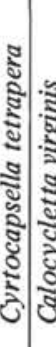 & 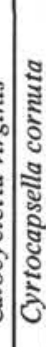 & 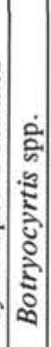 & 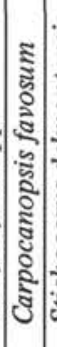 & 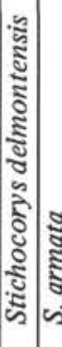 & 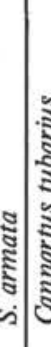 & 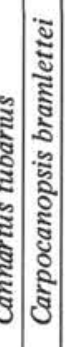 & 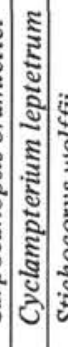 & 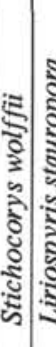 & 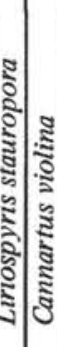 & 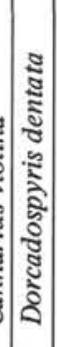 & 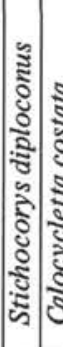 & 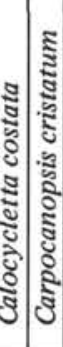 & 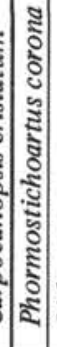 & 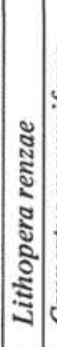 & 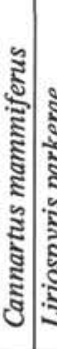 & 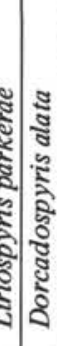 & $\mid$ & 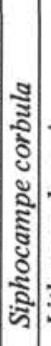 & 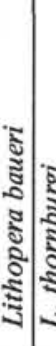 & 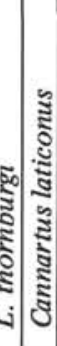 & 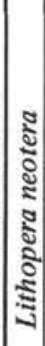 & 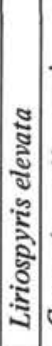 & 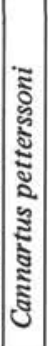 \\
\hline $\begin{array}{l}\text { St. Mark's, WRTR } 36 \\
\text { St. Mark's, WRTR } 38 \\
\text { Hermitage, WRTR } 11 \text { High } \\
\text { Hermitage, WRTR } 11 \text {, Low } \\
\text { St. Mark's, WRTR } 37 \\
\text { Philippine Rd., WRTR } 10\end{array}$ & - & & $\begin{array}{l}- \\
- \\
-\end{array}$ & $-\mid \begin{array}{l}- \\
- \\
R \\
R \\
- \\
R\end{array}$ & $\begin{array}{l}\mathrm{F} \\
\mathrm{R} \\
\mathrm{F} \\
\mathrm{F}\end{array}$ & $\begin{array}{l}\mathrm{R} \\
\mathrm{R} \\
\mathrm{R} \\
\mathrm{R}\end{array}$ & $\begin{array}{l}- \\
- \\
+ \\
- \\
+\end{array}$ & \begin{tabular}{l|l}
$\mathrm{A}$ & $\mathrm{R}$ \\
$\mathrm{F}$ & \\
$\mathrm{C}$ & $\mathrm{F}$ \\
$\mathrm{A}$ & $\mathrm{F}$ \\
$\mathrm{C}$ & $\mathrm{R}$ \\
$\mathrm{R}$ & $\mathrm{F}$
\end{tabular} & 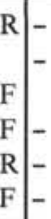 & $\begin{array}{l}\mathrm{R} \\
\mathrm{R} \\
\mathrm{R}\end{array}$ & \begin{tabular}{l|l}
$F$ & - \\
+ & - \\
+ & - \\
$R$ & $R$ \\
+ & $R$ \\
& $R$
\end{tabular} & $\begin{array}{l}- \\
\mathrm{R} \\
\mathrm{R} \\
\mathrm{R}\end{array}$ & $\begin{array}{l}- \\
- \\
+ \\
+ \\
+\end{array}$ & $\begin{array}{l}- \\
+ \\
+ \\
-\end{array}$ & \begin{tabular}{l|l}
- & - \\
- & - \\
- & $F$ \\
- & $F$ \\
- & $R$
\end{tabular} & \begin{tabular}{l|l}
- & + \\
$-F$ & - \\
$F$ & $R$ \\
$F$ & $R$ \\
$R$ & -
\end{tabular} & \begin{tabular}{|l|}
$\mathrm{F}$ \\
$\mathrm{R}$ \\
$\mathrm{R}$ \\
$\mathrm{R}$ \\
+ \\
$\mathrm{F}$ \\
\end{tabular} & $\begin{array}{l}\mathrm{F} \\
+ \\
\mathrm{R} \\
\mathrm{R} \\
+ \\
\mathrm{R}\end{array}$ & 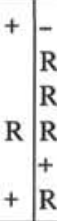 & $\begin{array}{l}R \\
R \\
R \\
+ \\
R\end{array}$ & $\begin{array}{l}+ \\
- \\
\mathrm{R} \\
+ \\
-\end{array}$ & $\begin{array}{l}- \\
- \\
-\end{array}$ & \begin{tabular}{l|l}
$\mathrm{R}$ & - \\
- & - \\
+ & - \\
- & -
\end{tabular} & $\begin{array}{l}\mathrm{R} \\
\mathrm{R} \\
\mathrm{F}\end{array}$ & + & $\begin{array}{l}+ \\
+\end{array}$ & \\
\hline $\begin{array}{l}\text { Golconda, WRTR } 23 \\
\text { Golconda, TTOC } 178888\end{array}$ & $\overline{\mathrm{R}}$ & $\begin{array}{l}+ \\
\mathrm{R}\end{array}$ & $\begin{array}{l}+ \\
\mathrm{F} \\
+\end{array}$ & \begin{tabular}{l|l}
- & $F$ \\
+ & $C$
\end{tabular} & $\bar{R}$ & $\mathrm{R}$ & & \begin{tabular}{l|l}
$\mathrm{C}$ & $\mathrm{F}$ \\
$\mathrm{R}$ & $\mathrm{R}$
\end{tabular} & \begin{tabular}{l|l}
$\mathrm{F}$ & + \\
$\mathrm{R}$ & -
\end{tabular} & $\mid \begin{array}{l}\mathrm{R} \\
+\end{array}$ & $+\begin{array}{l}+ \\
+\end{array}$ & \begin{tabular}{l|l}
$\mathrm{R}$ & $\mathrm{R}$ \\
$\mathrm{A}$ & $\mathrm{F}$
\end{tabular} & \begin{tabular}{l|l}
$\mathrm{R}$ \\
$\mathrm{R}$
\end{tabular} & $\begin{array}{l}\mathrm{R} \\
\mathrm{R}\end{array}$ & \begin{tabular}{|l|l}
- & + \\
- & +
\end{tabular} & + & $\mathrm{R}$ & & \begin{tabular}{l|l}
+ \\
+
\end{tabular} & & & & & & & & \\
\hline
\end{tabular}


1598) contains Eusyringium fistuligerum, Sethochytris triconiscus (?), Podocyrtis chalara and P. mitra, but lacks the Lithocyclia aristotelis group, Thyrsocyrtis tetracantha and Podocyrtis goetheana, and thus belongs in the Podocyrtis chalara Zone or in the unzoned interval characterized by $P$. goetheana. Of two samples from the quarry east of Bissex Hill (Saunders, 1968, Stop 11; samples WRTR 41 and 42, from Saunders' localities JS 1629 and 1628, respectively), the former contains Sethochytris triconiscus (?) and evolutionarily advanced specimens of Podocyrtis mitra, and is therefore high in the Podocyrtis mitra Zone, while the latter contains in addition Podocyrtis chalara and thus belongs in the $P$. chalara Zone-the section here may be steeply dipping or overturned, since at the time of collection WRTR 41 was recorded as being from higher in the exposure than WRTR 42. Samples WRTR 44 and 45 (corresponding to Saunders' localities JS 1643 and 1644, respectively), from the quarry at Springfield, contain Podocyrtis ampla and primitive representatives of $P$. mitra and lack Sethochytris triconiscus (?), and may be assigned to the Podocyrtis mitra Zone. A sample collected at a road-side outcrop east of Bissex Hill (Saunders, 1968, Stop 12; WRTR 43, corresponding to JS 1630) contains Eusyringium lagena (?), Theocotyle venezuelensis, Thyrsocyrtis triacantha and Podocyrtis sinuosa, and thus belongs in the Podocyrtis ampla Zone or the Thyrsocyrtis triacantha Zone.

Finally, a sample from near Hopefield Plantation provided by W. F.-Auer contains Eusyringium lagena (?), Thyrsocyrtis triacantha, Podocyrtis ampla and $P$. sinuosa, and no Eusyringium fistuligerum, and thus belongs in the early part of the Podocyrtis ampla Zone.

The only non-calcitized radiolarian assemblage that we have seen from the Navet Formation of Trinidad is that in Renz sample 336 from Friendship Quarry, near milepost 5 of the Princes Town Road (Bolli, 1957b, p. 158), which contains members of the Lithocyclia ocellus group, Lithochytris vespertilio, Thyrsocyrtis triacantha, Theocampe mongolfieri, and doubtfully identifiable Theocotyle venezuelensis and Podocyrtis sinuosa, and is thus probably assignable to the Thyrsocyrtis triacantha Zone.

Two samples from the Toledo member of the Universidad Formation of Habana Province, Cuba (Bermudez sample nos. 310 from Cantera San Francisco, Puentes Grandes, and 351 from Cantera Central Toledo) contain well-preserved, diverse assemblages including Theocotyle cryptocephala (?) nigriniae, Thyrsocyrtis hirsuta hirsuta, Podocyrtis aphorma, P. sinuosa and rare specimens of Theocampe mongolfieri, and thus belong in the lower part of the Theocampe mongolfieri Zone. An older Cuban Eocene assemblage is discussed in connection with the radiolarians occurring at Site 67.

\section{COMMENTS}

\section{7a. Preservation of Radiolarians}

At the Leg 7 drilling sites, radiolarians are commonly well preserved through long sequences of cores, and most of the occurrences of poorly preserved radiolarians are readily explained as being the result of the normal difference between sediments deposited beneath the Equatorial Current System (highly radiolarian) and those deposited beneath the Central Water Masses (and containing few, poorly preserved siliceous microfossils) (Riedel, 1959a; Riedel and Funnell, 1964). In addition to the poorly preserved assemblages mentioned in the section on paleo-environmental interpretations, the scarcity or absence of siliceous microfossils in the following cores may well be due to accumulation outside the area of influence of the biologically productive Equatorial Current System-Cores 62.0-6 to 62.0-8, 63.0-6 to $63.0-9,66.0-4$ to $66.0-8$, and 67.1-1.

In addition to these long sequences of poorly preserved assemblages, there is a shorter interval that merits special consideration. Radiolarians are poorly preserved to absent in Cores 62.1-38 and 62.1-39, and it is not immediately apparent why this is the case, nor why the same effect was not observed in sediments of the same age in the continuously cored section at the nearby Site 63.

\section{7b. Paleoenvironmental Interpretations}

All of the Cenozoic sequences cored at Sites 62 through 66 appear to have normal tropical radiolarian assemblages, with the exception of the uppermost Miocene and Pliocene at Sites 62 and 63 (from about 90 to 200 meters below the sediment surface at Site 62 and about 15 to 30 meters at Site 63). In those intervals, radiolarian assemblages are commonly poorly preserved, and less diverse than normal tropical assemblages, with many spongodiscids, few artiscins and collosphaerids, and occurrences of Pterocanium prismatium so sporadic that the definition of radiolarian zones is difficult. The scarcity and poor preservation of radiolarians, as well as the listed characteristics of the assemblages, are more characteristic of sediments beneath the North and South Central Pacific Water Masses than those beneath the Equatorial Current System.

\section{7c. Hiatuses in Sedimentation}

There are only two intervals in the cored Cenozoic sequences at which hiatuses in sedimentation or exceptional shortening of the column are indicated by the radiolarian evidence.

At Site 65, between the lower part of 65.0-7 and the top of 65.0-8, an interval representing the Dorcadospyris alata Zone (which occupies approximately 20 meters at some other sites) may be compressed or missing. 
At Site 64 there appears to be a hiatus or condensed section between 915 and 970 meters (between Cores 64.1-9 and 64.1-10), but a complete radiolarian sequence corresponding to this interval was not cored at other sites and therefore the amount of shortening of the section is uncertain.

\section{7d. New Information on Phylogeny}

Our report on radiolarians from Leg 4 of the drilling expedition (Riedel and Sanfilippo, in press) includes a summary of what was then known of Cenozoic radiolarian phylogeny, and we here add only the advances made on the basis of the Leg 7 material.

Artiscinae. It now seems clear that this subfamily developed from Lithocyclia angustum by reduction of the number of spongy columns from three to two, and displacement of the axis of radial symmetry through $90^{\circ}$.

Spongaster. The development of this genus from a circular spongodiscid in the Ommatartus antepenultimus Zone is clearly demonstrated. The relationships of superficially similar earlier forms remain to be worked out.

Liriospyris parkerae. Intermediate forms, with reduced pores in the frontal ring, link this species with the ancestral $L$. stauropora.

Psychospyris. This remarkable genus, comprised of a lineage of the three species Psychospyris parva, $P$. intermedia and $P$. grandis, evidently evolved from Dendrospyris anthocyrtoides.

Dorcadospyris ateuchus. The Leg 7 material provides more convincing evidence than was previously available, for the development of this species from Tristylospyris triceros.

Cyclampterium (?). The phylogenetic sequence of species observed in the Leg 7 material corresponds to that described (Sanfilippo and Riedel, in press) on the basis of scattered piston cores, and the lineage is extended back in time by the recognition of Cyclampterium (?) milowi as the ancestor of $C$. (?) pegetrum. The ultimate origin of the lineage is still not known.

Lychnocanium sp. aff. L. bellum. This distinctive species evidently evolved directly from $L$. bellum, and appears to represent the termination of the lineage.

Artostrobium doliolum, Phormostichoartus corona, Siphocampe corbula and Spirocyrtis scalaris. The forms ancestral to these species have been determined and illustrated, but not named.

\section{SYSTEMATIC SECTION}

The taxonomy applied here is heavily dependent upon other papers which we have recently completed (Sanfilippo and Riedel, in press; Riedel and Sanfilippo, in press). In the synonymies of species that have previously been treated adequately, we here include only the reference to the original description and figure, the reference to the new combination if the generic name now used differs from that to which the species was originally assigned, and a reference to a paper defining the present concept of the species.

Genera are arranged alphabetically within families, and species alphabetically within genera.

Type specimens and some other figured specimens will be deposited in the U.S. National Museum, Washington, D. C.

\section{8a. Family COLLOSPHAERIDAE Müller 1858}

A preliminary survey was made to determine the earliest occurrence of members of this family, and to determine whether any species or genera could easily be used for correlation. The earliest occurrence observed in the drill-cores was a Siphonosphaera? in the Calocycletta virginis Zone, and in slightly younger assemblages the genera Collosphaera, Polysolenia, Solenosphaera and Tribonosphaera are also present. Thus, none of these genera in the sense of Hilmers (1906), is very restricted stratigraphically, and we describe only one species of Solenosphaera which appears to be useful for late Neogene correlations. In the synchronopticon, however, we illustrate a number of the more common forms (Plate 1A, Figures 1-24; Plate 1B, Figures 1-17; Plate 1C, Figures 1-4; Plate 2A, Figures 1-15; Plate 2B, Figures $1-8)$.

\section{Genus Solenosphaera Haeckel 1887}

Solenosphaera omnitubus Riedel and Sanfilippo, new species (Plate 1A, Figures 23, 24; Plate 4, Figures 1, 2).

Description: Shell small, approximately spherical, with 4 to 8 short, truncate, cylindrical tubes without differentiated termination, which occupy most of the surface of the sphere. Pores small, subcircular, not very variable in size, similar on the tubes and the sphere.

Measurements based on 30 specimens from 62.1-20-2, $84-86 \mathrm{~cm}$ and $66.1-4-3,25-27 \mathrm{~cm}$. Overall diameter (including tubes) 70 to $120 \mu$.

Remarks: This species differs from other members of the genus in the small number of tubes which occupy a very large proportion of the surface of the sphere. 
8b. Family aCtinommidae Haeckel 1862, emend. Riedel 1967b

Apart from a passing reference to Lithapium (?) anoectum, the only actinommids treated are the members of the subfamily Artiscinae. This is because we have no useful system for classifying the vast bulk of actinommids.

\section{Genus Lithapium Haeckel, 1887}

Lithapium (?) anoectum Riedel and Sanfilippo

Lithapium (?)anoectum Riedel and Sanfilippo, in press.

Subfamily A RTISCINAE Haeckel 1881, emend. Riedel 1967b

The Neogene sequences obtained in the Western Pacific confirm most of the details of the phylogenetic development of artiscins suggested previously (Riedel, 1959). The only significant point of difference concerns the origin of Cannartus tubarius, which was previously thought to have developed from Cannartus prismaticus, but which may actually have arisen more directly from a form closely related to Lithocyclia angustum-the form (Plate 4, Figure 3) mentioned below in the discussion of Doryphacus, Dorydruppa and Doryprunum.

The earliest specimens of Cannartus prismaticus provide rather convincing evidence that this species (the earliest representative of its family) developed from Lithocyclia angustum, by loss of one of the spongy arms of the latter, and the remaining two arms becoming the the spongy columns of the artiscin. Their cortical shell tends to be spherical, the two spongy columns tend not to be diametrically opposed, and the structure of the cortical shell of the two species is similar (Plate 4, Figure 5). The transition between these two species is very interesting, since it involves a fundamental change in the axis of rotational symmetry, which in the earlier form is through the short axis of a disc, and in the later form is along the long axis of an ellipsoid (homologous with a diameter of the earlier disc). This evident origin of the artiscins from a coccodiscid ancestor raises a question as to the appropriateness of the placement of the subfamily within the family Actinommidae.

At about the time that this transition was taking place, discoidal and ellipsoidal forms with latticed spines appeared, which may possibly have some connection with the Lithocyclia-Cannartus transition. In some of our Italian samples we have found a discoidal form with one latticed spine (Plate 4, Figure 4)-evidently belonging to Doryphacus Carnevale (1908)-which may have arisen from Lithocyclia angustum. And in some Pacific samples (62.0-5-2 to 62.0-5-4) of perhaps similar age there is a form with a rather irregularly ellipsoidal cortical shell, medullary shell(s?) connected to it by equatorially disposed bars, and a remarkably similar latticed spine (Plate 4, Figure 3). This form fits within the definition of Dorydruppa or Doryprunum of Vinassa (1898), and may bear a similar relationship to Cannartus as Doryphacus does to Lithocyclia.

In this report we take account of the short-lived species Ommatartus avitus (Riedel), which has been overlooked in some recent papers (Riedel and Funnell, 1964; Riedel and Sanfilippo, in press). Thus, all known artiscins are treated systematically, except for the following two.

In the sequences at the westernmost drilling sites, in some of the assemblages containing Cannartus mammiferus or C. antepenultimus, occur rare specimens of a form which we have illustrated as Cannartus sp. (Plate 1D, Figure 1). This form has somewhat thinner walls than Cannartus prismaticus and polar columns not well developed, and has been found in Cores 62.1-26 to $62.1-32,63.0-2$ to $63.1-10$ and $64.0-3$ to $64.0-5$. It closely resembles Cannartus prismaticus, but is perhaps not closely related to it because there seems to be a gap between their ranges. It may have arisen from a form similar to Cannartus mammiferus, later becoming smooth and inflated, and ultimately losing the spongy columns.

Another form, also identified as Cannartus sp. (Plate $2 B$, Figures 9,10 ), has not been treated in detail. This is a rather narrow, very thin-walled, elongated form with distinct equatorial constriction, which has been found rarely in Cores 63.1-11 to 63.1-13 and 64.1-6.

Division of the artiscins into the two genera Cannartus and Ommatartus in the sense used herein is not very satisfactory, since it divides the continuous lineage from Cannartus tubarius to Ommatartus tetrathalamus into two parts, and does not reflect the natural relationships of the short Cannartus (?) petterssoniOmmatartus hughesi lineage. However, it seems undesirable to change the generic classification prior to publication of the paper (Riedel, in press) in which the system used here is established.

Genus Cannartus Haeckel 1881, emend. Riedel in press The emended definition admits artiscins with spongy polar columns only, and no distinct polar caps.

Cannartus laticonus Riedel (Plate 1C, Figures 13,14)

Cannartus laticonus Riedel, 1959b, p. 291, pl. 1, fig. 5.

Cannartus mammiferus (Haeckel)-(Plate 2C, Figures 1-3)

Cannartidium mammiferum Haeckel, 1887, p. 375, pl. 39, fig. 16.

Cannartus mammiferus (Haeckel), Riedel, 1959b, p. 291, pl. 1, fig. 4.

Cannartus (?) petterssoni Riedel and Sanfilippo (Plate 1C, Figures 19, 20) 
Cannartus petterssoni, manuscript name proposed provisionally in Riedel and Funnell, 1964, p. 310.

Cannartus (?) petterssoni Riedel and Sanfilippo, in press.

Cannartus prismaticus (Haeckel)-(Plate 2C, Figures 11-13; Plate 4, Figure 5)

Pipettella prismatica Haeckel, 1887, p. 305, pl. 39, fig. 6; Riedel, 1959b, p. 287, pl. 1, fig. 1.

Cannartus prismaticus (Haeckel), Riedel and Sanfilippo, in press.

In some assemblages from the Lychnocanium bipes Zone, Cannartus prismaticus is accompanied by a form with rather similar cortical shell and two-bladed spines in place of the spongy columns (Plate 2C, Figure 14).

Cannartus tubarius (Haeckel) (Plate 2C, Figures 8-10) Pipettaria tubaria Haeckel, 1887, p. 339, pl. 39, fig. 15; Riedel, 1959b, p. 289, pl. 1, fig. 2.

Cannartus tubarius (Haeckel), Riedel and Sanfilippo, in press.

Cannartus violina Haeckel (Plate 2C, Figures 4-7)

Cannartus violina Haeckel, 1887, p. 358, pl. 39, fig. 10; Riedel 1959b, p. 290, pl. 1, fig. 3.

\section{Genus Ommatartus Haeckel 1881,} emend. Riedel in press

The emended definition includes artiscins with polar caps, and so sometimes spongy columns as well.

Ommatartus antepenultimus Riedel and Sanfilippo (Plate 1C, figures 11, 12)

Panarium antepenultimum, manuscript name proposed provisionally in Riedel and Funnell, 1964, p. 311.

Ommatartus antepenultimus Riedel and Sanfilippo, in press.

Ommatartus avitus (Riedel) (Plate 4, Figure 6)

Panartus avitus Riedel, 1953, p. 808, pl. 84, fig. 7.

This species, with tuberculate surface of the cortical shell and no spongy columns on the well developed polar caps, is intermediate between Ommatartus antepenultimus and $O$. tetrathalamus.

Ommatartus hughesi (Campbell and Clark) (Plate 1C, Figures 17, 18)

Ommatocampe hughesi Campbell and Clark, 1944, p. 23, pl. 3, fig. 12.

Ommatartus hughesi (Campbell and Clark), Riedel and Sanfilippo, in press.

Ommatartus penultimus (Riedel) sensu stricto (Plate 1C, Figures 8-10)

Panarium penultimum Riedel, 1957, p. 76, pl. 1, fig. 1; Riedel and Funnell, 1964, p. 311.
Ommatartus penultimus (Riedel), Riedel and Sanfilippo, in press.

Ommatartus tetrathalamus (Haeckel) (Plate 1C, Figures 5-7)

Panartus tetrathalamus Haeckel, 1887, p. 378, pl. 40, fig. 3; Nigrini, 1967, p. 30, pl. 2, figs. 4 a-d.

\section{8c. Family COCCODISCIDAE Haeckel, 1862}

By dividing this family very coarsely into three groups (one with narrow spongy arms, the second with broad spongy arms, and the third with a spongy zone not subdivided into arms), we accommodate all representatives present in the assemblages. The family terminated by evolving into the Artiscinae.

Genus Lithocyclia Ehrenberg, sensu Riedel and Sanfilippo, in press

Lithocyclia angustum (Riedel) (Plate 3A, Figures 1, $2(?), 3)$

Trigonactura angusta Riedel,1959b, p. 292, pl. 1, fig. 6 . Lithocyclia angustum (Riedel), Riedel and Sanfilippo, in press.

Lithocyclia aristotelis (Ehrenberg) group (Plate 3A, Figures 4, 5)

Astromma aristotelis Ehrenberg, 1847b, p. 55, fig. 10. Lithocyclia aristotelis (Ehrenberg) group, Riedel and Sanfilippo, in press.

Lithocyclia ocellus Ehrenberg group (Plate 3A, Figure 6)

Lithocyclia ocellus Ehrenberg, 1854, pl. 36, fig. 30; 1873, p. 240.

Lithocyclia ocellus Ehrenberg group, Riedel and Sanfilippo, in press.

\section{8d. Family SPONGODISCIDAE Haeckel, emend. Riedel $1967 \mathrm{~b}$}

The only members of this family that we have treated are the genus Spongaster (of which the evolutionary development is presented), and a single species of Dictyocoryne.

\section{Genus Dictyocoryne Ehrenberg 1860}

Dictyocoryne ontongensis Riedel and Sanfilippo, new species (Plate 1E, Figures 1, 2; Plate 4, Figures 9, $10,11)$

Description: Central disc small, with usually 5 concentric rings. Three arms arranged usually in a Y-shape, with one angle smaller than the others, but in some early specimens at equal angles. Arms rarely with slight transverse zonation, parallel-sided or slightly expanding distally; one or more of them forked distally at a very 
obtuse angle, each branch being of approximately the same width as the distal part of the arm or wider, and with a bluntly rounded termination. Rarely, the terminations of the arms are doubly bifurcate (Plate 4, Figure 11). Some specimens have a patagium that occupies practically all of the space outlined by the arms and their bifurcations.

Measurements based on 30 specimens from 66.1-5-1, $25-27 \mathrm{~cm} ; 66.1-5-5,25-27 \mathrm{~cm}$; and $66.1-6-2,25-27 \mathrm{~cm}$. Maximum radius 116 to $215 \mu$.

Remarks: D. ontongensis differs from Chitonastrum jugatum Haeckel and C. lyra Haeckel in that the arms are more uniformly spongy, not pronouncedly transversely chambered, and from $C$. dicranodes Haeckel in that the three arms are approximately equal. It differs from Trigonastrum regulare $\mathrm{Haeckel}$ and $T$. gegenbauri (Haeckel) in that the angles of bifurcation are more obtuse, and from Rhopalodictyum bifidum Haeckel in that each branch of the bifurcation is as wide as the proximal part of the arm or wider.

In the absence of any satisfactory understanding of the relationships of this species, it could equally well be placed in the spongodiscid genera Dictyocoryne Ehrenberg or Rhopalodictyum Ehrenberg, or the "porodiscid" genera Chitonastrum Haeckel or Trigonastrum Haeckel. We have chosen to place it in Dictyocoryne because that genus is the earliest described, and is defined as having a "spongodiscid" rather than a "porodiscid" structure.

\section{Genus Spongaster Ehrenberg 1860}

Emended definition: This genus comprises the forms that appear to form a phylogenetic series from Spongaster klingi to $S$. tetras (the type species of the genus). The thickened marginal part of the skeleton is not uniform circular, but is differentiated into four or more (sometimes two) denser areas separated by less dense zones. None of the species is constantly three-armed as in the genera Euchitonia Ehrenberg, Dictyastrum Ehrenberg, Chitonastrum Haeckel, etc.

Remarks: In the earliest assemblages containing the genus Spongaster, there is a circular spongodiscid with thickened center and periphery and with a narrow cone ("pylome tube" of Schizodiscus, in Dogel and Reshetnyak, 1952) extending inward from the margin (Plate 1D, Figure 14). Specimens of Spongaster klingi often show a similar cone within one of the two diametrically opposed radial thickenings (Plate 1D, Figure 10; Plate 4, Figure 8), and early specimens of $S$. pentas also show such a structure within one of the thickened rays (Plate 1D, Figure 5; on the ray pointing downward). There seems to have been a strong tendency for the thickenings of the spongy disc to have become differentiated symmetrically with respect to this pylometube.

In addition to the species treated below, the genus may also include a semicylindrical form (Plate 1D, Figures
$11,12)$, perhaps homologous with the central area and two long radial thickenings of $S$. klingi, which occurs together with the latter species.

Well below the range of Spongaster as defined here, occurs a form (Plate 5, Figure 1), which fits the earlier concept of this genus but is evidently not related.

Spongaster klingi Riedel and Sanfilippo, new species (Plate 1D, Figures 8, 9, 10; Plate 4, Figures 7, 8)

"Elliptical spongodiscid", Kling, in press, pl. 1, fig. J.

Description: Finely spongy skeleton elliptical in outline. Especially thickened are the central area, two opposite radii (and especially their distal parts), and two bluntly crescentic zones near the periphery (one on either side of the thickened diameter). One of the thickened radii includes a narrow conical pylome-tube.

Measurements based on 30 specimens from 66.1-4-CC; 66.1-4-3, 25-27 cm; 66.1-4-1, 110-111 cm; and 66.1-3CC. Major diameter 325 to $405 \mu$; minor diameter 255 to $355 \mu$.

Remarks: This species differs from the other members of the genus in having only two thickened radii, and two crescentic thickenings. It is named for Stanley A. Kling, who first illustrated the species and deduced its origin from a circular spongodiscid.

Spongaster pentas Riedel and Sanfilippo (Plate 1D, Figures 5, 6, 7)

Spongaster pentas Riedel and Sanfilippo, in press.

This species apparently developed from a circular spongodiscid ancestor at about the same time as, or slightly later than, the first $S$. klingi. The earlier description of this species did not note the narrow pylometube visible within the distal part of one arm of some specimens.

Spongaster tetras Ehrenberg (Plate 1D, Figures 2, 3, 4)

Spongaster tetras Ehrenberg, 1860, p. 833; 1861, p. 301; 1872b, pl. 6 (3), fig. 8; Nigrini, 1967, p. 41, pl. 5, figs. la-b, 2 .

This species apparently developed from $S$. pentas, by reduction of the number of arms from five or six to four, and stabilization of the four-rayed symmetry. It seems that the pylome-tube characteristic of other members of the genus has been lost at this stage of phylogenetic development. Nigrini (1967, p. 43, pl. 5, fig. 2) has described an irregularly rectangular subspecies $S$. tetras irregularis characteristic of middle latitudes, which also occurs in some of our sequences at the westernmost drilling sites. In sequences in which $S$. tetras is represented by the subspecies irregularis, it is difficult to recognize the zone of transition from S. pentas. 
8e. Family ACANTHOdESMIIDAE Haeckel 1862, emend. Riedel 1967b

Only a small number of the many species of this family (=Trissocyclidae of Goll, 1968, 1969) are treated here.

\section{Genus Dendrospyris Haeckel 1881,} emend. Goll 1968

Dendrospyris anthocyrtoides (Bütschli) (Plate 5, Figures 5-7)

Petalospyris anthocyrtoides Bütschli, 1882b, p. 532, figs. $19 \mathrm{a}-\mathrm{b}$.

Dendrospyris anthocyrtoides (Bütschli), Goll, 1968, p. 1419, pl. 174, figs. 9, 11-14; text-fig. 8 .

Some late specimens of this species (e.g., Plate 5, Figure 7) tend to have the anterior and posterior faces of the cephalic lattice-shell more delicate than usual, and with smaller pores, and a rather robust thorny zone in the frontal plane-they thus approach Psychospyris parva.

\section{Genus Dorcadospyris Haeckel, 1881}

This generic name is here used in a much more restricted sense than applied by Goll (1969). We include in Dorcadospyris only those forms in which two feet are especially strongly developed, and exclude Tristylospyris triceros (the immediate ancestor of Dorcadospyris ateuchus), in which three feet are strongly developed.

Dorcadospyris alata (Riedel) (Plate 2D, Figure 1) Brachiospyris alata Riedel, 1959b, p. 293, pl. 1, figs. 11,12 .

Dorcadospyris alata (Riedel), Riedel and Sanfilippo, in press.

Dorcadospyris ateuchus (Ehrenberg) (Plate 2D, Figure 6; Plate 3A, Figures 9, 10)

Ceratospyris ateuchus Ehrenberg, 1873, p. 218; 1875, pl. 21, fig. 4.

Cantharospyris ateuchus (Ehrenberg), Haeckel, 1887, p. 1051; Riedel, 1959b, p. 294, pl. 22, figs. 3, 4.

Dorcadospyris ateuchus (Ehrenberg), Riedel and Sanfilippo, in press.

Evidence from the drilled sequences in the western Pacific confirms the suggestion by Riedel (1959) that this species evolved from Tristylospyris triceros by reduction of the number of strongly developed feet from three to two.

Dorcadospyris dentata Haeckel (Plate 2D, Figures 2, 3) Dorcadospyris dentata Haeckel, 1887, p. 1040, pl. 85, fig. 6; Riedel, 1957, p. 79, pl. 1, fig. 4.

Dorcadospyris forcipata (Haeckel) (Plate 2C, Figures 20-23; Plate 3A, Figure 8)
Dipospyris forcipata Haeckel, 1887, p. 1037, pl. 85 , fig. 1.

Dorcadospyris forcipata (Haeckel), Riedel and Sanfilippo, in press.

Dorcadospyris papilio (Riedel) (Plate 2D, Figures 4, 5; Plate 3A, Figure 7)

Hexaspyris papilio Riedel, 1959b, p. 294, pl. 2, figs. $1,2$.

Dorcadospyris papilio (Riedel), Riedel and Sanfilippo, in press.

Dorcadospyris simplex (Riedel)

Brachiospyris simplex Riedel, 1959b, p. 293, pl. 1, fig. 10.

Dorcadospyris simplex (Riedel), Riedel and Sanfilippo, in press.

Genus Liriospyris Haeckel 1881, emend. Goll 1968

Liriospyris elevata Goll (Plate 1E, Figure 3)

Liriospyris elevata Goll, 1968, p. 1426, pl. 175, figs. $4,5,8,9$; text-fig. 9 .

Liriospyris parkerae Riedel and Sanfilippo, new species (Plate 2C, Figure 15; Plate 5, Figure 4)

Description: Sagittal ring D-shaped, with a furrow on the anterior and posterior sides. Four collar pores, separated by the median and sternal (in the sense of Goll) bars and the primary lateral spines, are enclosed within the basal ring. The remainder of the skeleton is a simple longitudinally furrowed frontal ring, except that it is divided apically to join the upper part of the sagittal ring at two points. There is no apical spine, and the vertical spine is represented by a short thorn. At the base of the apical bar of the sagittal ring is a single small pore, near which can be distinguished two very small secondary lateral bars, and near the base of the vertical bar is a pair of small pores and near them a sternal bar (in the sense of Goll, 1968).

Measurements based on 25 specimens from 63.1-9-4, $15-16 \mathrm{~cm}$ and $64.0-5-4,84-86 \mathrm{~cm}$. Height of sagittal ring 50 to $70 \mu$, total width of skeleton 95 to $125 \mu$. Remarks: This species differs from Liriospyris stauropora, its immediate ancestor, in that the band-like lattice-shell of that species is here reduced to a poreless bar.

It is named for Frances L. Parker, whose investigations of Cenozoic foraminifera have contributed greatly to our understanding of the biostratigraphy of pelagic sediments.

Liriospyris stauropora (Haeckel) (Plate 2C, Figures 16-19)

Trissocyclus stauroporus Haeckel, 1887, p. 987, pl. 83, fig. 5. 
Liriospyris stauropora (Haeckel), Goll, 1968, p. 1431, pl. 175, figs. 1-3, 7; text-fig. 9 .

Goll's records of this species above the Lower Miocene are evidently due to the admixture of older forms into younger assemblages-a commonly occurring circumstance in deep-sea sediments of which his tabulation takes no account. Our evidence indicates that Liriospyris stauropora evolved into $L$. parkerae at about the boundary between the Calocycletta costata and Dorcadospyris alata Zones.

\section{Genus Psychospyris Riedel and Sanfilippo, new genus}

Type species: Psychospyris intermedia Riedel and Sanfilippo, new species.

Definition: This genus comprises the members of the lineage extending from Psychospyris parva through $P$. intermedia to $P$. grandis. There is a strong tendency for shell development to be concentrated in the frontal plane, and for the shells therefore to be discoidal in general form. The outer part of this disc usually consists of two lattice-plates joined by bars which give the appearance of a radially chambered structure, and the inner part (corresponding to the cephalic cavity or more) hollow. The primary and secondary lateral bars are well developed, and there is no basal ring in $P$. parva, though it may be present in the other species. Below the collar pores, and marked off from the remainder of the disc by the primary lateral bars and obliquely downwardly directed bars arising from them, is a type of "pocket". There are commonly two prominent bars arising from the top of the D-shaped sagittal ring (in the position denoted as " $q$ " by Petrushevskaya, 1969), and extending obliquely upward to the spongy zone at the top of the skeleton.

Remarks: In the phylogenetic development of this lineage, the overall size increases and the originally kidney-shaped outline becomes almost circular. Also, the ring, which has the usual D-shaped proportions in P. parva, becomes markedly elongated vertically in late $P$. intermedia and especially in P. grandis, and the hollow cephalic cavity becomes correspondingly larger in diameter. We have been surprised to find such a range of size and form in the sagittal ring of this genus, but there appears to be no doubt that the forms included here are in fact closely related.

This genus is distinguished from some species of Tholospyris (in the sense of Goll, 1969), which have the skeleton developed principally in the frontal plane, in the lack of strongly developed sagittal ring bars. Psychospyris may well have developed from Dendrospyris anthocyrtoides, which immediately precedes it in the cored sequences, by degeneration of the lattice plates on the anterior and posterior faces, strong development of the shell (first as spines and later as lattice plates) in the frontal plane, and increase in size.

The name is derived from the Greek psyche (=butterfly) and spyris (=basket), and is feminine.
Psychospyris grandis Riedel and Sanfilippo, new species (Plate 6, Figures 3-5)

Description: Cephalic cavity, together with the "pocket" below the lateral bars, almost circular in outline, covered by very delicate lattice-plates with pores resembling an irregular network rather than circular. Chambered zone narrow, dense, peripherally thorny, and similar in structure around the entire periphery. Sagittal ring high and delicate, at its upper end connected to the inner margin of the spongy zone by paired sagittal ring bars which are generally shorter than in $P$. intermedia.

Measurements based on 6 specimens from 66.1-8-CC, $66.0-2-1,25-27 \mathrm{~cm}$, and $66.0-2-3,25-27 \mathrm{~cm}$. Width of cephalic cavity 265 to $365 \mu$; height of sagittal ring 110 to $145 \mu$; greatest diameter of total skeleton 375 to $475 \mu$.

Remarks: This species is distinguished from Psychospyris intermedia by its larger size, subcircular outline and constantly elongated and delicate sagittal ring. This species evidently represents the termination of its lineage.

Psychospyris intermedia Riedel and Sanfilippo, new species (Plate 5, Figure 11; Plate 6, Figures 1,2)

Description: Cephalic cavity much larger than that of $P$. parva, in early specimens not bounded by a distinct frontal ring and in late specimens bounded by an apparently secondarily developed line at the inner margin of the chambered zone. Chambered zone in some specimens represented only by a zone of strongly developed thorns. Sagittal ring in early specimens similar to that of $P$. parva, and surmounted by a pair of long sagittal ring bars (in position " $q$ " of Petrushevskaya, 1969), and in later specimens much more delicate and higher. Lattice shell on anterior and posterior faces of cephalic cavity very delicate, with small pores, and often broken.

Measurements based on 15 specimens from 66.0-2-CC, $66.0-3-1,25-27 \mathrm{~cm}$, and $66.0-3-3,125-127 \mathrm{~cm}$. Width of cephalic cavity 195 to $330 \mu$; height of sagittal ring 50 to $115 \mu$; greatest diameter of total skeleton (including spines) 245 to $435 \mu$.

Remarks: This species is phylogenetically intermediate between Psychospyris parva and $P$. grandis, and is usually kidney-shaped or elliptical in outline rather than subcircular.

Psychospyris parva Riedel and Sanfilippo, new species (Plate 5, Figures 8-10)

Description: Bilobed cephalis of the usual acanthodesmiid form, its outline marked by an almost complete frontal ring. Anterior and posterior faces of this cephalic shell very delicate, with small subcircular pores. In the frontal plane, surrounding the cephalic shell, is a more robustly developed zone of chambered 
structure, which may be kidney-shaped, elliptical or circular in outline. The cephalic cavity is generally about a third to a half as wide as the total width of the skeleton.

Measurements based on 9 specimens from 66.0-3-5, $25-27 \mathrm{~cm}$ and $125-127 \mathrm{~cm}$. Width of cephalic cavity 130 to $170 \mu$; height of sagittal ring 65 to $80 \mu$; greatest diameter of total skeleton 205 to $365 \mu$.

Remarks: This species is distinguished from Psychospyris intermedia by the smaller cephalic cavity.

\section{Genus Tristylospyris Haeckel 1881}

The assignment of the following species to this genus is not based on any conviction that it is related to the type species of Tristylospyris, but is simply an application of Haeckel's binomen pending determination of its true relationships.

Tristylospyris triceros (Ehrenberg) (Plate 3A, Figures 11, 12)

Ceratospyris triceros Ehrenberg, 1873, p. 220; 1875, pl. 21 , fig. 5 .

Tristylospyris triceros (Ehrenberg), Haeckel, 1887, p. 1033.

\section{8f. Family THEOPERIDAE Haeckel, emend. Riedel $1967 b$}

We treat only a small proportion of the many forms in this large, probably polyphyletic family. The new genus Bekoma may differ sufficiently in its cephalic structure to warrant exclusion from this family, but it is retained here pending elucidation of its evolutionary origin.

\section{Genus Artophormis Haeckel 1881}

Artophormis barbadensis (Ehrenberg) (Plate 3B, Figures 8,9)

Calocyclas barbadensis Ehrenberg, 1873, p. 217; 1875, pl. 18 , fig. 8 .

Artophormis barbadensis (Ehrenberg), Riedel and Sanfilippo, in press.

Artophormis dominasinensis (Ehrenberg) (Plate 6, Figure 6)

Podocyrtis dominasinensis Ehrenberg, 1873, p. 250; 1875 , pl. 14 , fig. 4.

Artophormis dominasinensis (Ehrenberg), Riedel and Sanfilippo, in press.

This species has a thin poreless rim with few to many small teeth. The cephalis is not regularly three-lobed as might be deduced from Ehrenberg's figure.

Artophormis gracilis Riedel (Plate 3B, Figures 5-7; Plate 6, Figure 7)

Artophormis gracilis Riedel, 1959b, p. 300, pl. 2, figs. 12,13 .
Genus Bekoma Riedel and Sanfilippo, new genus

Definition: Shell consisting of cephalis, thorax, three robust feet, and usually some lattice in the abdominal position. The cephalis contains a well developed spicular structure, and the collar stricture is not as distinct as in most cyrtoids. From each foot arises an inwardly or downwardly directed rod, and these rods are sometimes connected to those of the neighboring feet by additional bars.

Remarks: This genus differs from other superficially similar theoperid genera by the combination of characters-lack of distinct collar stricture and characteristically pronged feet.

The generic name is an arbitrary combination of letters, and is treated as feminine.

The peculiar structure of the cephalis, in particular, seems to necessitate the erection of a new genus for the species described below. The fundamental spicule, with median bar and apical, vertical, and probably primary and secondary lateral rays, is well developed and not reduced to form the small collar pores normally associated with a pronounced collar stricture.

An undescribed species of this genus occurring in an apparently older Paleocene assemblage from Belus (Plate 6, Figure 8) has almost straight feet each with an inwardly directed rod. In the species occurring at Site 67 and in the Upper Paleocene at Ibbaritz-Bidarf, this latter rod changes its orientation to become downwardly directed, and thus collinear with the proximal part of the foot, and the original distal part of the foot is reduced to a small, outwardly directed thorn.

In rare specimens from Ibbaritz-Bidarf, bars are developed to join the inwardly directed rods of neighboring feet, but this has not been observed in specimens from Site 67, which might therefore be interpreted as slightly younger-Plate 7 , Figure 3 shows the manner of this joining in side view, and Plate 7, Figure 4 in plan view.

Bekoma bidarfensis Riedel and Sanfilippo, new species (Plate 7, Figures 1-7)

Description: Cephalis and thorax together campanulate, with three robust feet. Cephalis approximately hemispherical, with very thick wall, not marked off from the thorax externally. Cephalis seems generally poreless, but with numerous depressions resembling infilled pores. In some specimens the apical and vertical spines extend beyond the cephalic surface as two weak, oblique spines. Thorax campanulate, with somewhat rough surface, proximally narrow and forming a type of "neck" merging with the cephalis with no change in contour. Thoracic pores subcircular, smaller and sparser proximally. From (and slightly above) the distinct distal rim of the thorax arise three long, thick, subparallel cylindrical feet with an outwardly-directed thorn in the distal half (but see discussion of homologies 
below). In many specimens, the feet are irregularly hollow distally. Fragments of a latticed abdomen are commonly present.

Measurements based on 9 specimens from 67.1-2-CC. Length of cephalis plus thorax 145 to $165 \mu$; maximum breadth of thorax 130 to $170 \mu$.

Remarks: Specimens from Site 67, and some from the Upper Paleocene at Ibbaritz-Bidarf, have an outwardly directed thorn in the distal part of the robust rod which superficially resembles a foot. This thorn is evidently homologous with the terminal part of the straight foot of the form from Belus, and the structure distal from that is homologous with the inwardlydirected rod from which arise the bars that connect the three feet in some specimens.

\section{Genus Calocycloma Haeckel 1887}

Calocycloma (?) ampulla (Ehrenberg) (Plate 3B, Figure 4)

Eucyrtidium ampulla Ehrenberg, 1854, pl. 36, fig. 15; 1873 , p. 225.

Calocycloma (?) ampulla (Ehrenberg), Riedel and Sanfilippo, in press.

\section{Genus Cycladophora Ehrenberg 1847a}

Cycladophora hispida (Ehrenberg) (Plate 3B, Figures 10,11)

Anthocyrtis hispida Ehrenberg, 1873, p. 216; 1875, pl. 8, fig. 2.

Cycladophora hispida (Ehrenberg), Riedel and Sanfilippo, in press.

\section{Cycladophora turris (Ehrenberg)}

Calocyclas turris Ehrenberg, 1873, p. 218;1875, pl. 18, fig. 7.

Cycladophora turris Ehrenberg, Riedel and Sanfilippo, in press.

\section{Genus Cyclampterium Haeckel 1887}

Cyclampterium (?) brachythorax Sanfilippo and Riedel (Plate 1E, Figure 7)

Cyclampterium (?) brachythorax Sanfilippo and Riedel, in press.

Cyclampterium (?) leptetrum Sanfilippo and Riedel (Plate 2D, Figures 9-12)

Cyclampterium (?) leptetrum Sanfilippo and Riedel, in press.

Cyclampterium (?) milowi Riedel and Sanfilippo, new species (Plate 3B, Figure 3; Plate 7, Figures 8, 9)

Cyclampterium (?) sp., Sanfilippo and Riedel, in press, pl. 2 , fig. 7 .
Description: Shell robust, subcylindrical to campanulate, with the large abdomen bearing three latticed feet. Cephalis subspherical, with few small pores, bearing a short, broadly conical horn. Collar stricture usually pronounced, but less so when the wall of the cephalis is very thick. Thorax hemispherical, thick-walled, with subregular circular pores and surface smooth or slightly thorny. Abdomen subcylindrical or expanding distally, with robust bars separating large pores of variable size. The abdomen passes terminally into three irregular, coarsely latticed feet.

Measurements based on 30 specimens from 64.0-10-1, top, and $65.0-13-3,25-27 \mathrm{~cm}$. Total length 375 to $595 \mu$ (usually approximately $475 \mu$ ). Maximum breadth 235 to $375 \mu$ (usually approximately $275 \mu$ ). Length of the thorax 70 to $120 \mu$ (usually approximately $90 \mu$ ).

Remarks: This species differs from all others of the genus in possessing latticed feet. Dictyopodium eurylophos Ehrenberg (1873, p. 223; 1875, pl. 19, fig. 4) and D. oxylophos Ehrenberg (1873, p. 223; 1875, pl. 19, fig. 5) have latticed feet, but their entire skeleton and the meshes of their abdomen and feet are much smaller.

This species is named for E. Dean Milow, who noticed this species during his investigation of radiolarians from Leg 3 of the Deep-Sea Drilling expedition.

The phylogenetic origin of Cyclampterium (?) milowi is obscure. C. (?) pegetrum is apparently its immediate descendant.

Cyclampterium (?) neatum Sanfilippo and Riedel (Plate 1E, Figures 4-6)

Cyclampterium (?) neatum Sanfilippo and Riedel, in press.

Cyclampterium (?) pegetrum Sanfilippo and Riedel (Plate 2D, Figures 13, 14; Plate 3B, Figures 1,2)

Cyclampterium (?) pegetrum Sanfilippo and Riedel, in press.

Cyclampterium (?) tanythorax Sanfilippo and Riedel (Plate 1E, Figures 8-10; Plate 2D, Figures 7, 8)

Cyclampterium (?) tanythorax Sanfilippo and Riedel, in press.

\section{Genus Cyrtocapsella Haeckel 1887}

Cyrtocapsella cornuta Haeckel (Plate 2E, Figures 1-4) Cyrtocapsa (Cyrtocapsella) cornuta Haeckel, 1887, p. 1513, pl. 78 , fig. 9 .

Cyrtocapsella cornuta Haeckel, Sanfilippo and Riedel, in press.

Cyrtocapsella japonica (Nakaseko) (Plate 1F, Figure 1; Plate 2E, Figure 12)

Eusyringium japonicum Nakaseko, 1963, p. 193, pl. 4, Figs. 1-3. 
Cyrtocapsella japonica (Nakaseko), Sanfilippo and Riedel, in press.

Cyrtocapsella tetrapera Haeckel (Plate 2E, Figures 5-7)

Cyrtocapsa (Cyrtocapsella) tetrapera Haeckel, 1887, p. 1512 , pl. 78 , fig. 5 .

Cyrtocapsella tetrapera Haeckel, Sanfilippo and Riedel, in press.

\section{Genus Eucyrtidium Ehrenberg 1847a}

Eucyrtidium cubense Riedel and Sanfilippo, new species (Plate 7, Figures 10, 11)

Description: Upper three segments form a conical section of the shell, and fourth segment (separated from third by slight if any internal ledge) approximately cylindrical. Cephalis subspherical, with few small pores, and bearing a short bladed apical spine. Collar stricture indistinct externally. Thorax campanulate and abdomen inflated annular, separated by pronounced internal and slight external lumbar stricture. Pores of both thorax and abdomen subcircular, larger and more closely spaced on the abdomen. In most specimens, longitudinal ridges on the surface of thorax and proximal part of abdomen separate longitudinal rows of pores. Fourth segment subcylindrical, of densely spongy material. Termination ragged or broken in all observed specimens.

Measurements based on 9 specimens from 67.1-2-CC and Palmer's Cuban Eocene sample no. 4131. Length of first three segments 120 to $150 \mu$, their maximum breadth 90 to $135 \mu$.

Remarks: This species differs from all other known members of the genus in the spongy nature of the fourth segment. The general form is reminiscent of Stichocorys, but that genus is believed to have originated as $S$. delmontensis from a Eucyrtidium-like ancestor during the early Miocene-much later than the range of this species.

\section{Genus Eusyringium Haeckel 1881}

Eusyringium fistuligerum (Ehrenberg) (Plate 3B, Figure 14)

Eucyrtidium fistuligerum Ehrenberg, 1873, p. 229; 1875, pl. 9, fig. 3 .

Eusyringium fistuligerum (Ehrenberg), Haeckel, 1887, p. 1498.

Eusyringium fistuligerum (Ehrenberg), Riedel and Sanfilippo, in press.

Eusyringium lagena (Ehrenberg) (?)

[?] Lithopera lagena Ehrenberg, 1873, p. 241; 1875, pl. 3 , fig. 4 .

Eusyringium lagena (Ehrenberg) (?), Riedel and Sanfilippo, in press.

\section{Genus Lithocampium Haeckel 1881}

Lithocampium sp. A (Plate 7, Figure 12)

This species is evidently very closely related to that described from DSDP Leg 4 material as Lithocampium sp. (Riedel and Sanfilippo, in press). It is spindleshaped, consisting of four segments not separated by external constrictions, and the third segment is the largest. In the Leg 4 specimens, the quincuncially arranged pores of the third segment give the general impression of being aligned obliquely, but in the specimens from Site 67 the pores of the segment are rectangularly arranged, aligned longitudinally and transversely, with ridges separating the longitudinal rows. The pores of the thinner-walled, tapering fourth segment are regularly arranged in transverse rows.

\section{Genus Lithochytris Ehrenberg 1847a}

Lithochytris archaea Riedel and Sanfilippo (Plate 7, Figure 13)

Lithochytris archaea Riedel and Sanfilippo, in press.

Lithochytris vespertilio Ehrenberg

Lithochytris vespertilio Ehrenberg, 1873, p. 239; 1875, pl. 4, fig. 10; Riedel and Sanfilippo, in press.

\section{Genus Lithopera Ehrenberg 1847a}

Lithopera (Lithopera) bacca Ehrenberg (Plate 1F, Figures 10-13)

Lithopera bacca Ehrenberg, 1872a, p. 314; 1872b, pl. 8 , fig. 1 ; Nigrini, 1967 , p. 54, pl. 6, fig. 2; Sanfilippo and Riedel, in press.

Lithopera (Glomaria) baueri Sanfilippo and Riedel (Plate 1F, Figure 9)

Lithopera baueri Sanfilippo and Riedel, in press.

Lithopera (Lithopera) neotera Sanfilippo and Riedel (Plate 1F, Figures 14, 15; Plate 2E, Figure 19) Lithopera neotera Sanfilippo and Riedel, in press.

Lithopera (Lithopera) renzae Sanfilippo and Riedel (Plate 2E, Figures 17, 18; Plate 7, Figure 14)

Lithopera renzae Sanfilippo and Riedel, in press.

Lithopera (Glomaria) thornburgi Sanfilippo and Riedel (Plate 1F, Figure 8)

Lithopera thornburgi Sanfilippo and Riedel, in press.

Genus Lophocyrtis Haeckel 1887

Lophocyrtis (?) jacchia (Ehrenberg) (Plate 3C, Figures 4, 5; Plate 7, Figure 16) 
Thyrsocyrtis jacchia Ehrenberg, 1873, p. 261; 1875 , pl. 12 , fig. 7 .

Lophocyrtis (?) jacchia (Ehrenberg), Riedel and Sanfilippo, in press.

This species is characterized by the apical horn being supported by three (or possibly four) arches, abdomen subcylindrical or slightly expanded distally, with pores generally larger than those of the thorax, three (or four) terminal or subterminal feet usually divergent, and no differentiated peristome. Near the upper limit of this species the feet are lost (Plate 3C, Figure 5).

Genus Lychnocanium Ehrenberg 1847a

Lychnocanium bellum Clark and Campbell

Lychnocanium bellum Clark and Campbell, 1942, p. 72, pl. 9, figs. 35, 39; Riedel and Sanfilippo, in press.

Lychnocanium sp. aff. L. bellum Clark and Campbell (Plate 3C, Figures 1, 2)

We have used this designation for a form with shorter and thinner hollow feet and larger thorax than $L$. bellum, and often an inverted cap-shaped abdomen which incorporates the feet and in some individuals closes the shell aperture. The wall of the abdomen is spongy, and a spongy layer often covers the regular pores of the thorax. This form evidently developed from $L$. bellum.

Lychnocanium bipes Riedel (Plate 2F, Figures 1, 2) Lychnocanium bipes Riedel, 1959b, p. 294, pl. 2, figs. 5,6 .

Lychnocanium trifolium Riedel and Sanfilippo, new species (Plate 3B, Figure 12; Plate 8, Figures 2, 3)

Description: Cephalis spherical, poreless, bearing a conical or three-bladed apical horn. Collar stricture pronounced. Thorax campanulate, with smooth surface and subcircular pores generally arranged in groups of three separated by wide poreless areas. Three feet three-bladed, approximately straight, longer than the thorax.

Measurements based on 20 specimens from 64.0-8-2, $84-86 \mathrm{~cm}$. Length excluding horn and feet 75 to $90 \mu$. Maximum breadth of thorax 75 to $90 \mu$.

Remarks: This species differs from all other members of the genus in the characteristic grouping of thoracic pores in threes.

\section{Genus Phormocyrtis Haeckel 1887}

Phormocyrtis striata Brandt (Plate 8, Figure 4)

Phormocyrtis striata Brandt 1935, in Wetzel, 1935, p. 55 , pl. 9, fig. 12; Riedel and Sanfilippo, in press.

Genus Pterocanium Ehrenberg 1847a

Pterocanium prismatium Riedel (Plate 8, Figure 1)
Pterocanium prismatium Riedel, 1957, p. 87, pl. 3, figs. 4-5; Riedel and Sanfilippo, in press.

\section{Genus Sethochytris Haeckel 1881}

Sethochytris babylonis (Clark and Campbell) group (Plate 3B, Figure 13)

Dictyophimus babylonis Clark and Campbell, 1942, p. 67 , pl. 9, figs. 32,36 .

Sethochytris babylonis (Clark and Campbell) group, Riedel and Sanfilippo, in press.

Sethochytris triconiscus Haeckel (?)

Sethochytris triconiscus Haeckel, 1887, p. 1239, pl. 57, fig. 13; (?) Riedel and Sanfilippo, in press.

\section{Genus Stichocorys Haeckel 1881}

Stichocorys armata (Haeckel) (Plate 2E, Figures 13-15) Cyrtophormis armata Haeckel, 1887, p. 1460, pl. 78, fig. 17.

This species is evidently closely related to Stichocorys diploconus, and is therefore transferred to the same genus.

Stichocorys delmontensis (Campbell and Clark) (Plate 1F, Figures 5-7; Plate 2E, Figures 10, 11)

Eucyrtidium delmontense Campbell and Clark, 1944, p. 56, pl. 7, figs. 19, 20.

Stichocorys delmontensis (Campbell and Clark), Sanfilippo and Riedel, in press.

As in previous papers, we here define Stichocorys delmontensis very broadly, to include virtually all stichocyrtids (except for Stichocorys wolffii) in which a conical upper part of the shell formed of the first three segments is distinguished from a distal, narrower subcylindrical part comprised of the fourth and subsequent segments. At Sites 63 and 64, a form conforming to this definition appears commonly below the earliest occurrence of $S$. wolffii, becomes rare during the lower part of the range of $S$. wolffii, and then again common in younger samples.

Stichocorys diploconus (Haeckel) (Plate 2E, Figure 16) Cyrtocapsa diploconus Haeckel, 1887, p. 1513, pl. 78, fig. 6 .

Stichocorys diploconus (Haeckel), Sanfilippo and Riedel, in press.

Stichocorys peregrina (Riedel) (Plate 1F, Figures 2-4; Plate 8, Figure 5)

Eucyrtidium elongatum peregrinum Riedel, 1953, p. 812 , pl. 85 , fig. 2 .

Stichocorys peregrina (Riedel), Riedel and Sanfilippo, in press.

Stichocorys wolffii Haeckel (Plate 2E, Figures 8, 9) 
Stichocorys wolffii Haeckel, 1887, p. 1479, pl. 80 , fig. 10; Riedel, 1957, p. 92, pl. 4, figs. 6, 7.

\section{Genus Theocorys Haeckel 1881}

Theocorys anapographa Riedel and Sanfilippo

Theocorys anapographa Riedel and Sanfilippo, in press.

Theocorys spongoconum Kling (Plate 2F, Figure 4; Plate 3C, Figure 3)

Theocorys spongoconum Kling, in press.

Genus Theocotyle Riedel and Sanfilippo, in press

Theocotyle cryptocephala (?) nigriniae Riedel and Sanfilippo

Theocotyle cryptocephala (?) nigriniae, Riedel and Sanfilippo, in press.

Theocotyle (?) ficus (Ehrenberg)

Eucyritidium ficus Ehrenberg, 1873, p. 228; 1875, pl. 11, fig. 19.

Theocotyle (?) ficus (Ehrenberg), Riedel and Sanfilippo, in press.

Theocotyle venezuelensis Riedel and Sanfilippo

Theocotyle venezuelensis Riedel and Sanfilippo, in press.

\section{Genus Thyrsocyrtis Ehrenberg 1847b}

Thyrsocyrtis bromia Ehrenberg (Plate 8, Figure 6) Thyrsocyrtis bromia Ehrenberg, 1873, p. 260; 1875, pl. 12, fig. 2; Riedel and Sanfilippo, in press.

This species is characterized by the large, subcircular abdominal pores, often thorny surface, and very short feet (sometimes absent).

Thyrsocyrtis hirsuta hirsuta (Krasheninnikov)

Podocyrtis hirsutus Krasheninnikov, 1960, p. 300, pl. 3 , fig. 16.

Thyrsocyrtis hirsuta hirsuta (Krasheninnikov), Riedel and Sanfilippo, in press.

Thyrsocyrtis rhizodon Ehrenberg (Plate 3C, Figure 6)

Thyrsocyrtis rhizodon Ehrenberg, 1873, p. 262; 1875, pl. 12, fig. 1; Riedel and Sanfilippo, in press.

Thyrsocyrtis tetracantha (Ehrenberg)

Podocyrtis tetracantha Ehrenberg, 1873, p. 254; 1875 , pl. 13 , fig. 2.

Thyrsocyrtis tetracantha (Ehrenberg), Riedel and Sanfilippo, in press.

Under this name we include specimens with up to five or six feet.
Thyrsocyrtis triacantha (Ehrenberg) (Plate 3C, Figure 7)

Podocyrtis triacantha Ehrenberg, 1873, p. 254; 1875, pl. 13, fig. 4 .

Thyrsocyrtis triacantha (Ehrenberg), Riedel and Sanfilippo, in press.

8g. Family CARPOCANIIDAE Haeckel, emend. Riedel $1967 \mathrm{~b}$

We have included illustrations of all common members of this family in the synchronopticon, but have been unable to bring any satisfactory systematic order to the largest group of species, here lumped under the name Carpocanistrum spp.

The taxonomic position of the genus Carpocanium Ehrenberg (and therefore the appropriate name for the family) is somewhat uncertain, because its type species (Lithocampe solitaria Ehrenberg, 1838, p. 130; 1854 , pl. 22, fig. 28) may, perhaps, be related to the artostrobiid genus Carpocanarium.

\section{Genus Carpocanistrum Haeckel, 1887}

Carpocanistrum spp. (Plate 1G, Figures 1-6, 8-13; Plate 2F, Figures 5-16; Plate 3D, Figures 1, 2, 6, 7, 9)

Included under this name are most of the forms commonly thought of as typical carpocaniids-with cephalis not markedly distinguished in contour from the ovate thorax, pores often longitudinally aligned, and a somewhat constricted peristome often bearing numerous teeth. Resolution of the question as to whether or not forms with a more distinct cephalis (Plate $1 \mathrm{G}$, Figures 7, 14, 15; Plate 3D, Figures 3-5, 8) are appropriately included here must await more detailed morphological studies.

Campbell's (1954), p. D 119) action in synonymizing Carpocanistrum Haeckel with Lithocarpium Stöhr is unsatisfactory, because Haeckel (1887, p.1172) assigned the type species of the latter genus (Lithocarpium pyriforme Stohr, 1880, p. 97, pl. 3, fig. 10) only doubtfully to his new genus Carpocanistrum. We therefore here designate, as type species of Carpocanistrum Haeckel, Carpocanistrum evacuatum Haeckel (1887, p. 1172, pl. fig. 11).

\section{Genus Carpocanopsis Riedel and Sanfilippo, new genus}

Type species: Carpocanopsis cingulatum Riedel and Sanfilippo, new species.

Definition: Robust Carpocaniidae with an abdomen separated from the thorax by a lumbar stricture that is well developed internally.

Remarks: Our object in erecting this genus is to provide a place, distinct from the genus Carpocanistrum, for a group of carpocaniids of heavy construction, with 
an abdomen, and a lumbar stricture that is pronounced internally. It might be suspected that they arose from a form resembling the late Eocene Cryptoprora ornata Ehrenberg (1873, p. 222; 1875, pl. 5, fig. 8) (Plate 3D, Figures 10,11$)$, but we have not found any connecting forms in the early and middle Oligocene parts of our sections.

It is not yet certain that this is a natural genus comprising closely related species, but the fact that the species assigned here have some structural similarities and occur together over a rather short period of time indicates that they may be phylogenetically related.

Carpocanopsis bramlettei Riedel and Sanfilippo, new species (Plate 2G, Figures 8-14; Plate 8, Figure 7) Cycladophora favosa Haeckel, Riedel, 1954, pl. 1, fig. 3 (non 2).

Description: Cephalis externally obtusely cap-shaped, generally separated from the thorax by a slight change in contour. Thorax barrel-shaped, with smooth surface and circular pores longitudinally aligned. Lumbar stricture expressed externally by a distinct change in contour. Abdomen subcylindrical, hyaline, usually with one row of pores proximally and a row of teeth terminally.

Measurements based on 25 specimens from 63.1-14-1, $10-12 \mathrm{~cm}$; 66.0-2-3, 25-27 cm; and 66.1-8-3, 25-27 cm. Total length 115 to $190 \mu$. Maximum breadth 80 to $105 \mu$.

Remarks: This species is distinguished from $C$. favosum by the more pronounced longitudinal alignment of the thoracic pores, and by the abdomen being always subcylindrical.

It is named for M. N. Bramlette, who in addition to developing the stratigraphic applicability of calcareous nannofossils has taken every opportunity to assist the development of research on fossil radiolarians.

Carpocanopsis cingulatum Riedel and Sanfilippo, new species (Plate 2G, Figures 17-21; Plate 8, Figure 8)

Description: Cephalis obtusely cap-shaped, not separated from the thorax by an external collar structure. Thorax barrel-shaped, thick-walled (smaller and somewhat thinner-walled in early specimens), with smooth surface and circular pores longitudinally aligned. Abdomen inverted truncate-conical, not distinguished in external contour from distal part of thorax, with rounded pores irregular in shape and arrangement. The termination of the abdomen is corroded in most specimens, but in a few is observed to consist of short, irregular, lamellar teeth.

Measurements based on 25 specimens from 63.1-14-1, $10-12 \mathrm{~cm}, 64.1-6-3,30-32 \mathrm{~cm}$, and $64.1-7-3,30-32 \mathrm{~cm}$. Length of cephalis plus thorax 95 to $115 \mu$. Maximum breadth 85 to $115 \mu$.
Remarks: This species differs from $C$. bramlettei and C. favosum in the abdomen being porous rather than hyaline, and from $C$. cristatum (Carnevale)? in the thorax having a greater number of pores, longitudinally aligned, and smoother surface.

Carpocanopsis cristatum (Carnevale)? (Plate 1G, Figure 16; Plate $2 \mathrm{G}$, Figures 1-7)

? Sethocorys cristata Carnevale, 1908, p. 31, pl. 4, fig. 18 .

? Sethocorys cristata var. Carnevale, 1908, p. 32, pl. 4, fig. 19 .

Description: Cephalis hemispherical, in rare specimens bearing a short apical spine, usually separated from the thorax by a change in external contour. Thorax inflated barrel-shaped, with very thick wall and rough surface, and with fewer pores than $C$. cingulatum and $C$. bramlettei, not longitudinally aligned. Abdomen usually represented by only a few corroded protuberances on the distal part of the thorax, but to judge from portions preserved on rare specimens it appears not to be separated from the thorax by an externally expressed stricture, and to have irregular pores similar to those of $C$. cingulatum.

Remarks: This species is distinguished from $C$. favosum by the abdomen being porous rather than hyaline, and evidently inverted truncate-conical (narrowing distally). It differs from $C$. cingulatum as indicated in the discussion of that species.

Dimensions and other features are generally similar to those given by Carnevale for specimens from the Italian Miocene, but we cannot be confident of the identity of our species with his until there is an opportunity to examine additional Italian material.

Carpocanopsis favosum (Haeckel) (Plate 2G, 15, 16; Plate 8, Figures 9-11)

Cycladophora favosa Haeckel, 1887, p. 1380, pl. 62, figs. 5, 6; Riedel, 1954 , p. 172 , pl. 1, fig. 2 (non 3).

Description: Cephalis obtusely cap-like, commonly marked off externally from the thorax by a slight change in contour. Thorax barrel-shaped, with smooth or slightly rough surface and circular pores usually not showing marked longitudinal alignment. Lumbar stricture usually pronounced externally; in rare specimens the shell wall is very thick, even to the extent of filling the external lumbar stricture (Plate 8, Figure 10). Abdomen usually truncate-conical, widening distally, hyaline and commonly longitudinally ribbed, terminating in a row of irregular teeth; but in rare specimens similar to that of $C$. bramlettei.

Measurements based on 15 specimens from 63.1-14-1, 10-12 cm; 64.1-4-3, 84-86 cm; 64.1-5-1, 20-22 cm; and $64.1-6-3,30-32 \mathrm{~cm}$. Total length 105 to $155 \mu$. Maximum breadth of thorax 70 to $95 \mu$. 
8h. Family PTEROCOR YIDAE Haeckel 1881, emend. Riedel 1967b

In the synchronopticon and in this systematic section we have been able to treat only a few genera of this family, namely Calocycletta, Podocyrtis with its two subgenera Podocyrtis and Lampterium, and Theocyrtis. Lack of time has prevented our treating the genera Anthocyrtidium, Lamprocyclas, Theoconus and Theocorythium, and their relatives.

\section{Genus Calocycletta Haeckel 1887}

Calocycletta costata (Riedel) (Plate 2H, Figures 12-14) Calocyclas costata Riedel, 1959b, p. 296, pl. 2, fig. 9. Calocycletta costata (Riedel), Riedel and Sanfilippo, in press.

Calocycletta virginis Haeckel (Plate 2H, Figures 5-11) Calocyclas (Calocycletta) virginis Haeckel, 1887, p. 1381, pl. 74, fig. 4.

Calocycletta virginis Haeckel, Riedel and Sanfilippo, in press.

Near the lower limit of occurrence of Calocycletta virginis occurs a related form (Plate 8, Figure 12) with feet broad and shovel-shaped rather than narrowly lamellar. A similar form was recorded in the material from DSDP Leg 4 (Riedel and Sanfilippo, in press).

Calocycletta sp. (Plate 1G, Figures 17, 18; Plate 2H, Figures 1-3)

Under this name we have included forms rather similar to $C$. virginis, but lacking the elongated, parallel-sided feet. Early specimens are difficult to distinguish from C. virginis because the assemblages are corroded (and the abdomen therefore tends to be dissolved), but in late specimens it can often be seen that the abdominal pores lose their longitudinal alignment distally. Some specimens have short, triangular feet terminally. The shape of the thorax is inflated-hemispherical in the early forms and campanulate (so that the cephalis and thorax together are onion-shaped) in late forms. It is possible that more than one species is included under this name, and only the latest occurrence of the late form has been used as a datum for correlation in this report.

\section{Genus Podocyrtis Ehrenberg 1847a}

Podocyrtis (Podocyrtis) ampla Ehrenberg

Podocyrtis (?) ampla Ehrenberg, 1873, p. 248; 1875, pl. 16, fig. 7.

Podocyrtis (Podocyrtis) ampla Ehrenberg, Riedel and Sanfilippo, in press.

Podocyrtis (Podocyrtis) diamesa Riedel and Sanfilippo Podocyrtis (Podocyrtis) diamesa Riedel and Sanfilippo, in press.
Podocyrtis (Podocyrtis) papalis Ehrenberg (Plate 3E, Figure 1)

Podocyrtis papalis Ehrenberg, 1847b, fig. 2; 1873, p. 251.

Podocyrtis (Podocyrtis) papalis Ehrenberg, Riedel and Sanfilippo, in press.

Podocyrtis (Lampterium) aphorma Riedel and Sanfilippo

Podocyrtis (Lampterium) aphorma Riedel and Sanfilippo, in press.

Podocyrtis (Lampterium) chalara Riedel and Sanfilippo

Podocyrtis (Lampterium) chalara Riedel and Sanfilippo, in press.

Podocyrtis (Lampterium) goetheana (Haeckel) (Plate 8, Figure 13)

Cycladophora goetheana Haeckel, 1887, p. 1376, pl. 65 , fig. 5 .

Podocyrtis (Lampterium) goetheana (Haeckel), Riedel and Sanfilippo, in press.

Podocyrtis (Lampterium) mitra Ehrenberg (Plate 3D, Figure 19)

Podocyrtis mitra Ehrenberg, 1854, pl. 36, fig. B20; 1873, p. 251.

Podocyrtis (Lampterium) mitra Ehrenberg, Riedel and Sanfilippo, in press.

Podocyrtis (Lampterium) sinuosa Ehrenberg (?)

[?] Podocyrtis sinuosa Ehrenberg, 1873, p. 253;1875, pl. 15, fig. 5 .

Podocyrtis (Lampterium) sinuosa Ehrenberg (?), Riedel and Sanfilippo, in press.

\section{Genus Theocyrtis Haeckel 1887}

Theocyrtis annosa (Riedel) (Plate 2H, Figure 4; Plate 3D, Figures 12,13)

Phormocyrtis annosa Riedel, 1959b, p. 295, pl. 2, fig. 7 . Theocyrtis annosa (Riedel), Riedel and Sanfilippo, in press.

Theocyrtis tuberosa Riedel (Plate 3D, Figures 14, 15)

Theocyrtis tuberosa Riedel, 1959b, p. 298, pl. 2, figs. 10,11 .

Remarks: This species is preceded by an ancestral form in which the thoracic wall is smooth or plicate (and occasionally slightly tuberose). The evolutionary lower limit of the species is defined as that level at which tuberose specimens predominate over those that are not tuberose. 


\section{8i. Family ARtostrobiIDAE Riedel, 1967a}

All common members of this family are included in the synchronopticon, but some are not understood sufficiently to permit their inclusion in the tables of occurrences or the summary range-chart. We have not been able to trace long evolutionary lineages within this family, and are therefore unable at this time to suggest any substantial revision of the generic classificationbefore this can be done, it will probably be necessary to investigate cephalic structures in detail. We have, however, found forms ancestral to some of the late Cenozoic species, and the times of transition between ancestors and descendants will probably prove useful as biostratigraphic datum-levels.

\section{Genus Artostrobium Haeckel, 1887}

Artostrobium auritum (Ehrenberg) group (Plate 1H, Figures 5-8)

Lithocampe aurita Ehrenberg, 1844, p. 84; 1854, pl. 22 , fig. 25 .

Lithocampe lineata Ehrenberg, 1838, p. 130 (partim); 1854, pl. 19, fig. 54.

[?] Lithostrobus seriatus Haeckel, 1887, p. 1474, pl. 79 , fig. 15.

[?] Lithostrobus lithobotrys Haeckel, 1887, p. 1475, pl. 79 , fig. 17 .

[?] Lithostrobus botryocyrtis Haeckel, 1887, p. 1475 , pl. 79 , figs. 18,19 .

[?] Dictyomitra ferminensis Campbell and Clark, 1944 , p. 51 , pl. 7 , fig. 7.

[?] Dictyomitra montereyana Campbell and Clark, 1944 , p. 52 , pl. 7 , fig. 8 .

[?] Lithomitra bramlettei Campbell and Clark, 1944, p. 53 , pl. 7, figs. 10-14.

Included here are all artostrobiids with more than four segments separated by rounded constrictions, and having numerous rows of pores on each segment. The only other species that might be confused with this group is a possible ancestor of Spirocyrtis scalaris (Plate 1G, Figures 19, 20, 22) which has sharper intersegmental constrictions, usually more prominent lateral tubule and apical horn (the latter replaced by a tube in some specimens), and a greater number of segments which continue to become wider distally rather than attaining a constant width or becoming narrower.

Artostrobium doliolum Riedel and Sanfilippo, new species (Plate 1H, Figures 1-3; Plate 8, Figures 14, 15)

Description: Spindle-shaped, four-segmented artostrobiids in which the intersegmental strictures are not strongly pronounced externally. Cephalis very small, spherical, bearing a lateral tubule that lies along the thoracic wall and is thus directed obliquely downward. Thorax and third segment truncate-conical; fourth segment the widest, tapering distally, in some specimens with a poreless peristome. All post-cephalic segments with pores in closely-spaced transverse rows.

Measurements based on 30 specimens from 62.1-24-6, 63.0-2-4, 66.1-3-3 and 66.1-4-3. Total length 95 to 150 $\mu$. Maximum breadth 75 to $100 \mu$ (usually about $85 \mu$ ).

Remarks: This species differs from all described members of the family in the broadly spindle-shaped form of the four-segmented shell, without very pronounced external strictures.

It apparently developed from a form with less developed third segment, more widely separated rows of pores and somewhat more pronounced intesegmental strictures (Plate 1H, Figure 4; Plate 2I, Figures 1-8; Plate 3E, Figures 7-9) as we are not yet sure of the phylogenetic development of this form, its assignment to the genus Artostrobium is arbitrary.

Artostrobium miralestense (Campbell and Clark) (Plate 1H, Figures 9-17; Plate 2I, Figures 9, 10; Plate 3E, Figure 12)

Dictyocephalus miralestensis Campbell and Clark, 1944, p. 45 , pl. 6 , figs. $12-14$.

[?] Siphocampe erucosa Haeckel, 1887, p. 1500, pl. 79 , fig. 11.

[?] Eucyrtidium tumidulum Bailey, 1856, p. 5, pl. 1, fig. 11 ; Hays, 1965 , p. 181 , pl. 3 , fig. 7.

We have used this name for forms in which the shell wall is thick, and intersegmental constrictions (other than the collar and lumbar strictures) are unevenly spaced and in some specimens obscure. The lateral cephalic tubule is usually directed obliquely upward (commonly at about $45^{\circ}$ ). A distinct peristome is rarely present.

Campbell and Clark did not observe the lumbar stricture in this species, and therefore regarded it as dicyrtid. The species is here assigned to Artostrobium because it is evidently closely related to the type species of that genus (Lithocampe aurita Ehrenberg 1844, p. 84; 1854, pl. 22, fig. 25).

Genus Carpocanarium Haeckel, 1887

Carpocanarium spp. (Plate 11, Figures 17-25; Plate 2J, Figures 8, 9)

Eucyrtidium papillosum Ehrenberg, 1872a, p. 310; 1872 b, pl. 7, fig. 10 .

Dictyocephalus papillosus (Ehrenberg), Haeckel, 1887, p. 1307 ; Riedel, 1958 , p. 236 , pl. 3, fig. 10 , text-fig. 8 . Dictyocryphalus papillosus (Ehrenberg), Nigrini, 1967, p. 63, pl. 6, fig. 6 .

Carpocanium calycothes Stöhr, 1880, p. 96, pl. 3, fig. 8 . Dictyocephalus bergontianus Carnevale, 1908, p. 32, pl. 4, fig. 20 .

The designation "Carpocanarium spp." is here used for forms with hemispherical cephalis, distinct collar 
stricture, ovate thorax with rather few, rather large pores and occasionally three short spine-like wings in its proximal half, and a poreless subcylindrical peristome which in some specimens is irregularly terminated to give the impression of a corona of teeth. These forms include the type species of Carpocanarium Haeckel (Carpocanium calycothes Stöhr), and are not closely related to the type species of Dictyocryphalus (Cornutella obtusa Ehrenberg, 1844; p. 77; 1854, pl. 22, fig. 40), to which genus the best-known member of this group of species (Eucyrtidium papillosum Ehrenberg) has recently been assigned.

The phylogenetic origin of this group of species remains obscure. An inconspicuous lateral cephalic tubule is present in at least some specimens from the Sicilian Miocene, and from the lower part of the range of this group in the Western Pacific. Therefore they are assigned to the Artostrobiidae, although they do not have the transversely aligned pores characteristic of most members of the family.

\section{Genus Lithomitra Bütschli, 1882b}

Lithomitra lineata (Ehrenberg) group (Plate 11, Figures 1-11; Plate 2I, Figures 14-16; Plate 3E, Figure 14)

Lithocampe lineata Ehrenberg, 1838, p. 130 (partim); 1854 , pl. 22, fig. 26; pl. 36, fig. 16 .

Lithomitra lineata (Ehrenberg), Haeckel, 1887, p. 1484. Eucyrtidium lineatum arachneum Ehrenberg, 1861, p. 299.

Tricolocampe cylindrica Haeckel, 1887, p. 1412, pl. 66, fig. 21 ; aff., Nakaseko, 1963, p. 182, pl. 2, fig. 7.

Lithomitra nodosaria Haeckel, 1887, p. 1484, pl. 79 , fig. 1 .

Lithomitra eruca Haeckel, 1887, p. 1485, pl. 79, fig. 3.

Siphocampe annulosa Haeckel, 1887, p. 1500, pl. 79, fig. 10; cf., Nakaseko, 1963, p. 195, pl. 4, fig. 8 .

Tricolocampe sanpedroana Campbell and Clark, 1944, p. 50 , pl. 7 , fig. 5 .

Lithomitra altamiraensis Campbell and Clark, 1944, p. 53, pl. 7, fig. 9.

Siphocampium sp. Bachmann et al., 1963, p. 133, pl. 8, fig. 40 .

Members of the species-group are illustrated in the synchronopticon, and some occurrences are tabulated, but the limits of its range are not yet known. We include in this group three-segmented forms with cylindrical or subcylindrical abdomen perforated by regular, rather widely spaced transverse rows of pores (e.g., Plate 1I, Figures 2, 5) and also forms in which the abdomen has the appearance of being segmented as a result of the development of rounded constrictions alternating with the rows of pores (e.g., Plate 1I, Figures 9, 10). Not included in this group, but also illustrated, are forms which are rather similar but with somewhat inflated abdomen (Plate 1I, Figure 12; Plate 2I, Figure 17; Plate 3E, Figures 15-19).

Assignment to the genus Lithomitra is based partly on the possibility that the constituent species may be related to its type species (Eucyrtidium pachyderma Ehrenberg 1873 , p. $231 ; 1875$, pl. 11, fig. 21), and partly on the desirability of separating members of this species-group from more inflated forms with a welldifferentiated peristome (genus Theocampe).

\section{Genus Phormostichoartus Campbell, 1951}

Phormostichoartus corona Haeckel (Plate 1I, Figures 13-15; Plate 2J, Figures 1-5)

Cyrtophormis (Acanthocyrtis) corona Haeckel, 1887, p. 1462 , pl. 77 , fig. 15 .

Lithostrobus cf. botryocyrtis Haeckel, Nakaseko, 1963, p. 185 , pl. 3 , figs. $11 \mathrm{a}$, b.

Although Haeckel's illustration of this species shows a very different termination to the shell than do our photographs, there is little doubt that the two are identical. Haeckel's specimen was from Challenger Station 225 (a Miocene locality, see Riedel, 1954), and on searching through a large number of radiolarians from that sample we have found no specimen with large triangular "teeth" or lobes terminally, but many specimens corresponding to ours. Some specimens are terminated by being broken along a line of pores, and in this sense might be described as having very small terminal "teeth" which were perhaps exaggerated by Haeckel's illustrator.

In Phormostichoartus corona the third segment has more than two transverse rows of pores. The species is characterized by having four segments (the last segment considerably larger than the others, skirt-like, contracting distally and without a differentiated peristome), intersegmental strictures curved, not pronounced internally, a well-developed apical horn and a prominent, duck-billed lateral tubule.

This species appears to have developed from a form (Plate 2J, Figure 6; Plate 3F, Figures 1-6) in which the third segment has only two transverse rows of pores, and the apical horn and lateral tubule are generally not so prominent. Also closely related seems to be a form (Plate 2J, Figure 7) with only three segments, the last segment having a narrow "neck" proximally which tends to be limited distally by an incipient stricture.

Phormostichoartus (name proposed for the junior homonym Acanthocyrtis Haeckel, 1887, p. 1461, by Campbell, 1951, p. 530) is here used as the generic name because this species is evidently more closely related to the type species of that taxon (Cyrtophormis cylindrica Haeckel, 1887, p. 1461, pl. 77, fig. 17) than it is to the type species of Cyrtophormis ( $C$. armata Haeckel, 1887 , p. 1460 , pl. 78 , fig. 17). 


\section{Genus Siphocampe Haeckel, 1881}

Siphocampe corbula (Harting) (Plate 1H, Figures 18-25)

Lithocampe corbula Harting, 1863, p. 12, pl. 1, fig. 21. Siphocampe corbula (Harting) Nigrini, 1967, p. 85, pl. 8 , fig. 5 ; pl. 9 , fig. 3 .

Tricolocampe polyzona Haeckel, 1887, p. 1412, pl. 66, fig. 19.

Tricolocampe stenozona Haeckel, 1887, p. 1413, pl. 66, fig. 20.

Lithomitra schencki Campbell and Clark, 1944, p. 54, pl. 7, fig. 16.

This species, originally poorly described and illustrated by Harting from Quaternary sediment, and evidently excessively subdivided by later authors (Haeckel, Campbell and Clark) has been adequately redescribed by Nigrini. In the Leg 7 material, it is preceded by a form (Plate 2I, Figure 13) which is generally similar but which has only three segments and a thicker wall, and is preceded and for a time accompanied by an apparently related form with larger pores (Plate $1 \mathrm{H}$, Figures 26-28; Plate 2I, Figures 11-13). The cephalic tubule in Siphocampe corbula lies on the surface of the upper part of the thorax and is therefore directed downward, and a distinctly differentiated peristome is present. The cephalis appears to be large and cap-shaped, but this is merely due to the small spherical cephalis and the collar stricture being obscured by thickening of the wall of the proximal part of the thorax.

\section{Genus Spirocyrtis Haeckel, 1881}

Spirocyrtis scalaris Haeckel (Plate 1G, Figures 25-27) Spirocyrtis scalaris Haeckel, 1887, p. 1509, pl. 76, fig. 14; Nigrini, 1967, p. 88, pl. 8, fig. 7; pl. 9, fig. 4.

This species apparently arose from a form (Plate 1G, Figures 19-24; Plate 2H, Figures 15-18) in which the outlines of the segments are not angular but rounded. This ancestral form has sharp rather than rounded intersegmental constrictions, and usually has a prominent, duck-billed lateral cephalic tubule and apical horn (the latter in some specimens replaced by a tube).

\section{Genus Theocampe Haeckel, 1887}

Theocampe armadillo (Ehrenberg) group (plate 3E, Figures 3-6)

Eucyrtidium armadillo Ehrenberg, 1873, p. 225; 1875, pl. 9 , fig. 10 .

[?] Theocorys ovata Haeckel, 1887, p. 1416, pl. 69, fig. 16 .

In this group we include relatively large, three-segmented artostrobiids with a distinct peristome and commonly with a large apical horn and prominent lateral cephalic tubule. One of the forms included here (Plate 3E, Figures 3,5 ) resembles Eucyrtidium armadillo Ehrenberg from the Eocene of Barbados, and another (Plate 3E, Figure 4) may be related to Theocorys ovata Haeckel.

We assign this species-group to the genus Theocampe because of the possibility that its constituent species are related to Theocampe mongolfieri.

\section{Theocampe mongolfieri (Ehrenberg) (plate 3E, Figure} 13)

Eycyrtidium mongolfieri Ehrenberg, 1854, pl. 36, fig. 18B; 1873 , p. $230 ; 1875$, pl. 10, fig. 3.

Theocampe mongolfieri (Ehrenberg), Burma, 1959, p. 239; Riedel and Sanfilippo, in press.

Theocampe pirum (Ehrenberg)(Plate 3E, Figures 10,11)

Eucyrtidium pirum Ehrenberg, 1873, p. 232; 1875, pl. 10, fig. 14.

Theocampe pirum (Ehrenberg), Haeckel, 1887, p. 1423.

This three-segmented form has the last segment wide in normal view but compressed in the sagittal plane, and with a differentiated peristome. We have found similar, laterally compressed specimens in the Thyrsocyrtis bromia Zone of the Oceanic Formation of Barbados, and therefore use Ehrenberg's specific name.

8j. Family CANnobotryidaE Haeckel, emend. Riedel $1967 \mathrm{~b}$

In our report on radiolarians from Leg 4 of the DeepSea Drilling Project, the only cannobotryid in the Middle Eocene sequence at Site 29 is illustrated (Riedel and Sanfilippo, in press, Plate 12, Figure 10). It has a relatively large cephalic chamber, a small antecephalic chamber, no very distinct postcephalic chamber, and a subcylindrical thorax. This form may be closely related to that illustrated as Lithobotrys geminata by Ehrenberg $(1875$, pl. 3, fig. 19) and Bütschli (1882a, pl. 30, figs. 3a-c; $1882 \mathrm{~b}$, pl. 33, figs. $27 \mathrm{a}-\mathrm{c}$ ), from the Oceanic Formation of Barbados. The considerable diversity of Neogene cannobotryids evidently arose subsequent to the Middle Eocene.

In this preliminary investigation of the Leg 7 radiolarians, we report on all of the more common cannobotryids in the Eocene and younger cores, but without attempting fine taxonomic distinctions. Thus we have not investigated their skeletal structure in sufficient detail to permit comparison with the results of Petrushevskaya $(1965,1968)$, and group our forms into broad genera resembling those of Haeckel rather than into Petrushevskaya's better-defined ones. Even at this gross level of discrimination, however, the various general forms of cannobotryids seem to be stratigraphically restricted.

Genus Acrobotrys Haeckel, 1881

Acrobotrys spp. (Plate 1J, Figures 12-16; Plate 2J, Figures 13-15; Plate 3F, Figure 8) 
Under this name we have tabulated occurrences of all cannobotryids with two prominent cephalic tubules forming approximately a right angle. Thus we apply the generic name in a sense closer to that of Haeckel (1887) than to that of Petrushevskaya (1965). Bachmann et al. (1963, p. 128, pl. 5, fig. 22) have reported a member of this genus from the Miocene of Austria.

Acrobotrys tritubus Riedel (Plate 1J, Figures 19, 20) Acrobotrys tritubus Riedel, 1957, p. 80 , pl. 1, fig. 5.

Genus Botryocyrtis Ehrenberg, 1860

Botryocyrtis spp. (Plate 1J, Figures 1-11; Plate 2J, Figures 10-12; Plate 3F, Figure 7)

We have used this name to include forms both with and without a "lumbar" stricture subdividing the conical or subcylindrical part of the shell distal from the cephalis, though Petrushevskaya (1965) would separate those without such a stricture into the genus Monotubus. Specimens without a "lumbar" stricture predominate in our older samples, and those with such a stricture predominate in younger samples.

\section{Genus Botryopyle Haeckel, 1881}

Botryopyle dictyocephalus Haeckel group (Plate 1J, Figures 21-26; Plate 2J, Figures 16-18; Plate 3F, Figures 9-12)

Botryopyle dictyocephalus Haeckel, 1887, p. 1113, pl. 96 , fig. 6 .

Botryocella multicellaris Haeckel, 1887, p. 1117, pl. 96 , fig. 12 .
In this species-group we have included all forms with a large antecephalic chamber, small postcephalic chamber, and a subcylindrical thorax, and without prominent cephalic tubes. This group apparently includes forms that Petrushevskaya (1965) assigned to the genera Botryopyle, Bisphaerocephalina, Acrobotrys and Botryocella. The most obvious variable among the skeletons included here is the degree of porosity of the shell wall-some are densely porous and others only very sparsely porous, hyaline.

The form that we have tabulated as Botryopyle sp. A (Plate 2J, Figures 20, 21; Plate 3F, Figure 13) appears to be closely related to this species-group. It has a small tubule arising proximally from both the anteand post-cephalic chambers, and lying close to the thoracic wall.

\section{Genus Centrobotrys Petrushevskaya, 1965}

Centrobotrys thermophila Petrushevskaya (Plate 1J, Figures 27-31; Plate 2J, Figure 19; Plate 3F, Figure 14)

Centrobotrys thermophila Petrushevskaya, 1965, p. 115, text-fig. 20; Nigrini, 1967, p. 49, text-fig. 26, pl. 5 , fig. 7 .

Centrobotrys (?) sp. A (Plate 3F, Figures 15, 16)

This form resembles Petrushevskaya's (1965) Centrobotrys at least superficially, in that the cephalis is surrounded by a large chamber that is not subdivided into ante- and post-cephalic parts. The apex of the cephalis is more rounded and the entire shell wall more porous than in $C$. thermophila. 


\section{REFERENCES}

Bachmann, Alfred, Papp, Adolf and Stradner, Herbert, 1963. Mikropaläontologische Studien im "Badener Tegel" von Frättingsdorf, N. Ö. Geol. Ges. Wien, Mitt. 56, (1), 117-210, pl. 1-24.

Bailey, J. W., 1856. Notice of microscopic forms found in the soundings of the Sea of Kamtschatka-with a plate. Am. J. Sci., Ser. 2, 22, 1-6, pl. 1.

Beckmann, J. P., 1953. Die Foraminiferen der Oceanic Formation (Eocaen-Oligocaen) von Barbados, Kl. Antillen. Eclogae Geol. Helv. 46 (2), 301-412, pl. 1630.

Bolli, H. M., 1957a. Planktonic foraminifera from the Oligocene-Miocene Cipero and Lengua Formations of Trinidad, B.W.I. Bull. U.S. Nat. Museum. 215, 97-123, pl. 22-29.

1957b. Planktonic foraminifera from the Eocene Navet and San Fernando Formations of Trinidad, B.W.I. Bull. U.S. Nat. Museum. 215, 155-172, pl. 35-39.

Bramlette, M. N., and Wilcoxon, J. A., 1967. Middle Tertiary calcareous nannoplankton of the Cipero section, Trinidad, W. I. Tulane Stud. Geol. 5 (3), 93-131.

Burma, B. H., 1959. On the status of Theocampe Haeckel, and certain similar genera. Micropaleontology. 5 (3), 325-330.

Bütschli, O. 1882a. Radiolaria. In Klassen und Ordnungen des Thier-Reichs. H. G. Bronn (Ed.) Vol. 1, pt. 1, 332-478, pl. 17-32.

1882b. Beiträge zur Kenntnis der Radiolarienskelette, insbesondere der Cyrtida. $Z$. Wiss. Zool. 36, 485-540, pl. 31-33.

Campbell, A. S., 1951. New genera and subgenera of Radiolarida. J. Paleontolog. 25 (4), 527-530.

1954. Radiolaria. In Treatise on Invertebrate Paleontology. R. C. Moore (Ed.). (Univ. Kansas Press and Geol. Soc. Am.), Pt. D. Protista 3, 11-163. and Clark, B. L., 1944. Miocene radiolarian faunas from Southern California. Geol. Soc. Am. Spec. Paper 51. vii + 76 p., 7 pl.

Carnevale, P., 1908. Radiolarie e silicoflagellati di Bergonzano (Reggio Emilia). R. Ist. Veneto Sci. Lett. Arti, Mem. 28 (3), 1-46, pl. 1-4.

Cita, M. B., Nigrini, Catherine, and Gartner, Stefan, 1970. Biostratigraphy. In Peterson, M.N.A. et al., 1970. Initial Reports of the Deep Sea Drilling Project, Volume II. Washington (U.S. Government Printing Office) 391-411.

Clark, B. L. and Campbell, A. S., 1942. Eocene radiolarian faunas from the Mt. Diablo area, California. Geol. Soc. Am. Spec. Paper 39. vii +112 p., 9 pl.

Dogel, V. A., and Reshetnyak, V. V., 1952. Materialy po radiolyariyam severo-zapadnoi chasti Tikhogo Okeana. Issled. Dalnevost. Morei SSSR. (3), 5-36.

Ehrenberg, C. G. 1838. Über die Bildung der Kreidefelsen und des Kreidemergels durch unsichtbare Organismen. Kgl. Akad. Wiss. Berlin, Abhandl. Jahre 1838, 59-147, pl. 1-4, 3 tables.
1844. Über 2 neue Lager von Gebirgsmassen aus Infusorien als Meeres-Absatz in Nord-Amerika und eine Vergleichung derselben mit den organischen Kreide-Gebilden in Europa und Afrika. $\mathrm{Kgl}$. Preuss. Akad. Wiss. Berlin, Ber. Jahre 1844, 57-97.

1847a. Über eine halibiolithische, von Herrn R. Schomburgk entdeckte, vorherrschend aus mikroskopischen Polycystinen gebildete, Gebirgsmasse von Barbados. Kgl. Preuss. Akad. Wiss. Berlin, Ber. Jahre 1846, 382-385, chart to p. 385 .

1847b. Über die mikroskopischen kieselschaligen Polycystinen als mächtige Gebirgsmasse von Barbados und über das Verhältniss der aus mehr als 300 Neuen Arten bestehenden ganz eigenthümlichen Formengruppe jener Felsmasse zu den jetzt lebenden Thieren und zur Kreidebildung. Eine neue Anregung zur Erforschung des Erdlebens. $\mathrm{Kgl}$. Preuss. Akad. Wiss. Berlin, Ber. Jahre 1847, 40-60, table opposite p. 54, 1 pl.

1854. Mikrogeologie. Leipzig, (Voss) xxviii + 374 p., Atlas, 31 p., 41 pl., Fortsetzung (1856) 88 p. +1 p. errata.

1860. Über den Tiefgrund des stillen Oceans zweischen Californien und den Sandwich-Inseln aus bis 15600' Tiefe nach Lieut. Brooke. Kgl. Preuss. Akad. Wiss. Berlin, Monatsber. Jahre 1860, 819-833.

1861. Über die Tiefgründ-Verhältnisse des Oceans am Eingange der Davisstrasse und bei Island. Kgl. Preuss. Akad. Wiss. Berlin, Monatsber. Jahre 1861, 275-315, chart opposite p. 276.

, 1872a. Mikrogeologischen Studien als Zusammenfassung der Beobachtungen des kleinsten Lebens der Meeres Tiefgründe aller Zonen und dessen geologischen Einfluss. Kgl. Preuss. Akad. Wiss. Berlin, Monatsber. Jahre 1872, 265-322.

1872b. Mikrogeologische Studien über das kleinste Leben der Meeres-Tiefgründe aller Zonen und dessen geologischen Einfluss. Kgl. A kad. Wiss. Berlin, Abhandl. Jahre 1872, 131-399, 1 chart, pl. 1-12.

1873. Grossere Felsproben des PolycystinenMergels von Barbados mit weiteren Erläuterungen. Kgl. Preuss. Akad. Wiss. Berlin, Ber. Jahre 1873, 213-263.

1875. Fortsetzung der mikrogeologischen Studien als Gesammt-Uebersicht der mikroskopischen Paläontologie gleichartig analysirter Gebirgsarten der Erde, mit specieller Rücksicht auf den Polycystinen-Mergel von Barbados. Kgl. A kad. Wiss. Berlin, Abhandl. Jahre $1875,1-225+1$ p. errata, pl. 1-30.

Goll, R. M., 1968. Classification and phylogeny of Cenozoic Trissocyclidae (Radiolaria) in the Pacific and Caribbean Basins. Part I. J. Paleontol. 42 (6), 1409-1432, pl. 173-176.

1969. Classification and phylogeny of Cenozoic Trissocyclidae (Radiolaria) in the Pacific and Caribbean Basins. Part II. J. Paleontol. 43 (2), 322339 , pl. 55-60. 
Haeckel, Ernst, 1862. Die Radiolarien. (Rhizopoda Radiaria). Berlin (Reimer), xiv +572 p.; Atlas, iv + $35 \mathrm{pl}$.

1881. Entwurf eines Radiolarien-Systems auf Grund von Studien der Challenger-Radiolarien. Jena. Z. Med. Naturwiss. 15 (new ser., vol. 8), (3), 418-472.

1887. Report on the Radiolaria collected by H.M.S. Challenger during the years 1873-76. Rept. Voyage Challenger, Zool. 18, clxxxviii + 1803 p., 140 pl., 1 map.

Harting, P., 1863. Bijdrage tot de kennis der mikroskopische faune en flora van de Banda-Zee. Koninkl. Akad. Wetenschap. Amsterdam, Verh. 10, 1-34, pls. 1-3.

Hays, J. D., 1965. Radiolaria and late Tertiary and Quaternary history of Antarctic Seas. Biology of Antarctic Seas II, Antarctic Research Ser. 5 (Am. Geophys. Union), 124-184.

Hilmers, Carl, 1906. Zur Kenntnis der Collosphaeriden. (Doctoral Diss., Kgl. Christian-Albrecht Univ. Kiel.) $1-95$, pl. 1.

Kling, S. A., In press. Radiolaria. In Heezen, B. C. et al., 1970. Initial Reports of the Deep Sea Drilling Project, Volume VI. Washington (U. S. Government Printing Office).

Krasheninnikov, V. A., 1960. Nekotorye Radiolyarii Nizhnego i Srednego Eotsena Zapadnogo Predkavkazya. Min. Geol. $i$ Okhr. Nedr SSSR Vses. Nauch.Issled, Geol. Neft. Inst. (16), 271-301, pl. 1.

Müller, Johannes, 1855. Über die im Hafen von Messina beobachteten Polycystinen. Kgl. Preuss. Akad. Wiss. Berlin, Ber. Jahre 1855, 671-674.

Nakaseko, Kojiro, 1963. Neogene Cyrtoidea (Radiolaria) from the Isozaki Formation in Ibaraki Prefecture, Japan. Sci. Rept. Osaka Univ. 12 (2), 165-198, pl. 1-4.

Nigrini, Catherine, 1967. Radiolaria in pelagic sediments from the Indian and Atlantic Oceans. Bull. Scripps Inst. Oceanog. Univ. Calif. 11, 125 p., 9 pl.

Petrushevskaya, M. G., 1965. Osobennosti konstruktsii skeleta radiolyarii Botryoidae (otr. Nassellaria). $\mathrm{Tr}$. Zool. Inst. Leningrad 35, 79-118.

1968. Gomologii v skeletakh radiolyarii Nassellaria. 2. Osnovnye skeletnye dugi slozhnoustroennykh tsefalisov Cyrtoidae i Botryoidae. Zool. Zh. 47 (12), 1766-1776.

1969. Gomologii v skeletakh radiolyarii Nassellaria. 3. Sagittalno koltso i perifericheskii skelet semeistv Stephoidae i Spyroidae. Zool Zh. 48 (5), 642-657.

Riedel, W. R., 1953. Mesozoic and Late Tertiary Radiolaria of Rotti. J. Paleontol. 27 (6), 805-813, pl. 84-85.

1954. The age of the sediment collected at Challenger (1875) Station 225 and the distribution of Ethmodiscus rex (Rattray). Deep-Sea Res. 1, 170-175.

1957. Radiolaria: a preliminary stratigraphy. Rept. Swed. Deep-Sea Exped. 6 (3), 59-96, pl. 1-4. 1958. Radiolaria in Antarctic sediments. Rept. B.A.N.Z. Antarct. Res. Exped., ser. B. 6, pt. 10, 217-255.

1959a. Siliceous organic remains in pelagic sediments. In Silica in Sediments. (Soc. Econ. Paleontol. Mineral., Spec. Publ. 7), 80-91.

Riedel, W. R., 1959b. Oligocene and Lower Miocene Radiolaria in tropical Pacific sediments. Micropaleontology. 5 (3), 285-302.

1967a. Some new families of Radiolaria. Proc. Geol. Soc. London. (1640), 148-149.

1967b. Subclass Radiolaria. In The Fossil Record. W. B. Harland et al. (Eds.) London (Geol. Soc. London), 291-298.

In press. Systematic classification of polycystine Radiolaria. In The Micropalaeontology of Oceans. B. M. Funnell and W. R. Riedel (Eds.) Cambridge (Cambridge Univ. Press).

and Funnell, B. M., 1964. Tertiary sediment cores and microfossils from the Pacific Ocean floor. Quart. J. Geol. Soc. London. 120, 305-368, pl. 14-32.

and Sanfilippo, Annika. In press. Radiolaria. In Bader, R.G. et al. 1970. Initial Reports of the Deep Sea Drilling Project, Volume IV. Washington (U.S. Government Printing Office).

Sanfilippo, Annika and Riedel, W. R. In press. PostEocene "closed" theoperid radiolarians. Micropaleontology.

Saunders, J. B., 1968. Field trip guide. Barbados. Trans. Fourth Caribbean Geol. Conf. 443-449.

and Cater, M. C., 1968. Excursion No. 3. Paleontological collecting trip. Trans. Fourth Caribbean Geol. Conf. 433-434.

Stöhr, Emil, 1880. Die Radiolarienfauna der Tripoli von Grotte Provinz Girgenti in Sicilien. Palaeontographica. 26, (Ser. 3, vol. 2). 71-124, pl. 17-23 (1-7).

Vinassa de Regny, P. E., 1898. Nuovi generi di radiolaire del miocene di Arcevia. Boll. Soc. Geol. Ital. 17, 197-198.

Wetzel, O., 1935. Die Mikropalaeontologie des Heiligenhafener Kieseltones (Ober-Eozän). Niedersaechs. Geol. Ver. Jahr. 27, 41-81, pl. 8-10.

\section{ACKNOWLEDGEMENTS}

Financial support for this study was provided by NSF Grant no. GA-11489. David Clegg prepared a number of special radiolarian slides, and the onerous tasks of typing and proofreading were competently performed by M. A. Hanger, M. A. Robertson and P. B. Helms. 


\section{PLATES}

Plates $1 \mathrm{~A}-3 \mathrm{~F}$ constitute a synchronopticon, with figures arranged in such a way that each horizontal row contains the prominent forms in an assemblage of one age, and vertical rows show changes in a group through time. The youngest assemblage is illustrated in the top row of Plate 1, and the oldest at the bottom of Plate 3 . The fifteen samples from which the illustrated specimens were obtained are the following:

Plate 1

66.1-1-CC

$66.1-2-1,25-27 \mathrm{~cm}$

$66.1-3-5,25-27 \mathrm{~cm}$

$66.1-5-3,30-32 \mathrm{~cm}$

$66.1-6-4,25-27 \mathrm{~cm}$

Plate 2

$66.1-8-3,25-27 \mathrm{~cm}$

$63.1-11-3,84-86 \mathrm{~cm}$

$63.1-14-1,10-12 \mathrm{~cm}$

64.1-6-3, 30-32 cm

$64.1-7-3,30-32 \mathrm{~cm}$

Plate 3

$64.0-8-2,84-86 \mathrm{~cm}$

$64.1-8-2,84-86 \mathrm{~cm}$

$64.0-10-2,11-13 \mathrm{~cm}$

64.1-9-1, 30-32 cm

$64.1-10-2,84-86 \mathrm{~cm}$
Because each horizontal row generally illustrates forms from a single sample, it has not been necessary to specify the sample in the explanation of each figure. However, in the rare cases in which it has not been possible to find a specimen suitable for illustration in one of the fifteen samples on which the synchronopticon is based, a specimen has been chosen from a sample of approximately the same age as a synchronopticon sample, and its source is specified in the figure explanation.

In the figure explanations, numbers preceded by $\mathrm{Ph}$., Sl. or Cse. or in the form " $\mathrm{Cl} .4561 / 2$ " indicate slides in the collection at Scripps Institution of Oceanography, and designations in the form "U35/1" indicate England Finder positions of the illustrated specimens on the slides.

Evolutionary limits (see Section 2) have been applied, where possible, for the species names used in the explanations to synchronopticon plates. Thus, for example, on Plate 3B both figures 8 and 9 are labelled Artophormis barbadensis (though figure 8 alone might be identified as $A$. gracilis), since the morphotype of $A$. barbadensis predominates in this assemblage. The abundance of each morphotype in an assemblage is indicated by "a" (abundant), and "c" (common), "f" (few), "r" (rare) or " + " (very rare) near the top of each figure.

Plates 4-8 illustrate taxonomically important specimens, most of which will be deposited in the U.S. National Museum. 
PLATE 1A

(Magnification 150X)

Figure 1

Collosphaera (?) Ph. 1, K28/4.

Figures 2-11 Collosphaera spp.

2: Ph. 1, B46/3.

3: Ph. 1, N17/2.

4: Ph. $1, \mathrm{P} 39 / 0$.

5: Ph. 1, V14/2.

6: Ph. 1, G53/4.

7: Ph. 1, D19/1.

8: Ph. 1, Y53/2.

9: Ph. 1, B32/0.

10: Ph. 1, H26/4.

11: Ph. 1, M28/0.

Figures 12-22 Solenosphaera spp.

12: Ph. 1, M37/0.

13: Ph. 1, L51/4.

14: Ph. $1, \mathrm{U} 40 / 0$.

15: Ph. 1, M24/2.

16: $\mathrm{Ph} .1, \mathrm{~K} 51 / 0$.

17: Ph. 1, Y46/0.

18: Ph. 1, Q43/4.

19: Ph. 1, Y50/0.

20: Ph. 1, G26/0.

21: Ph. $1, \mathrm{~N} 53 / 0$.

22: Ph. 1, Y52/2.

Figures 23, 24 Solenosphaera omnitubus

Riedel and Sanfilippo, n. sp.

23: Ph. 1, N20/3.

24: Ph. 1, Q51/4. 
Plate 1A
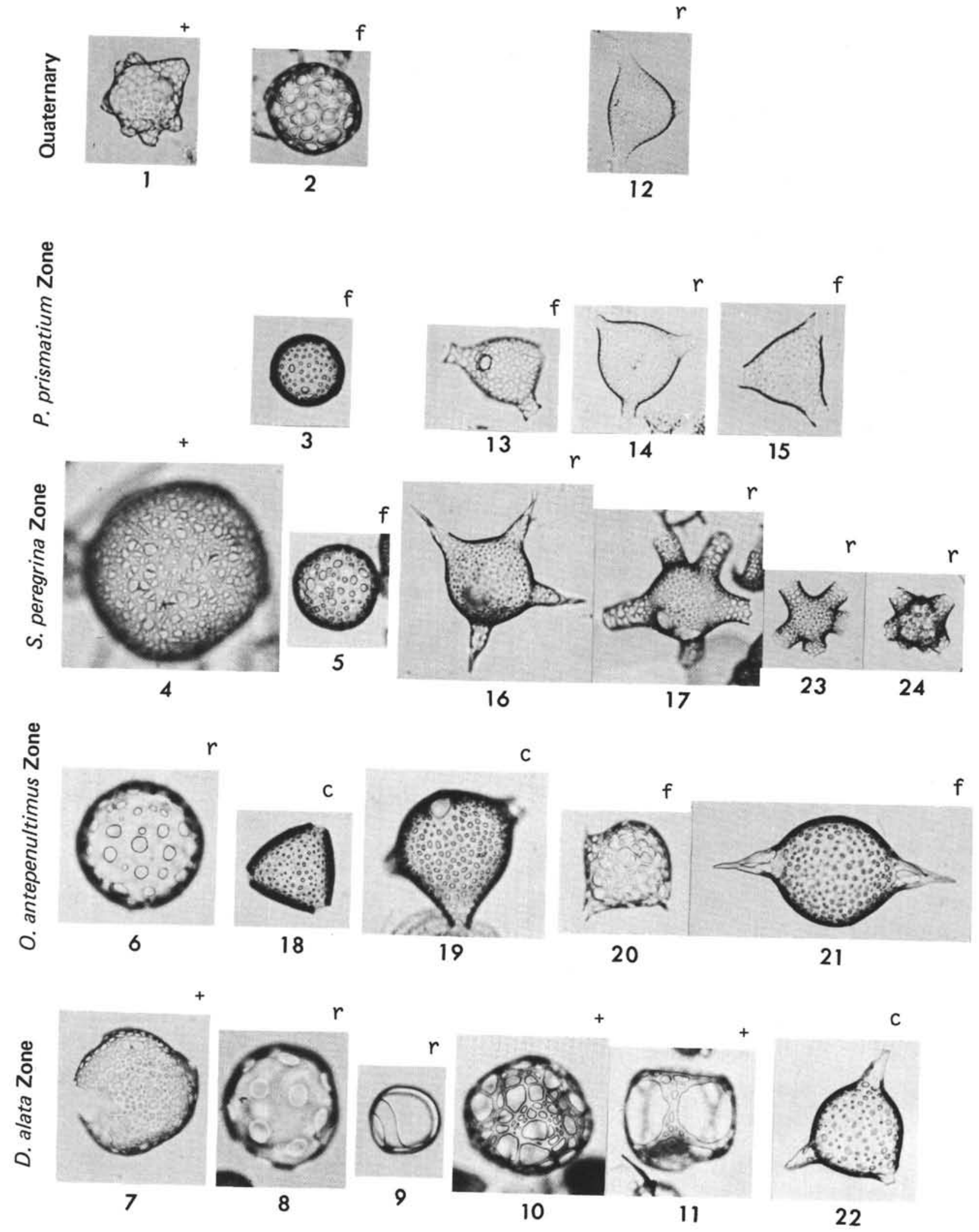


\section{PLATE 1B}

(Magnification 150X)

Figures 1-15 Polysolenia spp.

1: Ph. $1, \mathrm{U} 35 / 1$.

2: Ph. $1, \mathrm{~T} 38 / 2$.

3: Ph. 1, Q33/0.

4: Ph. $1, \mathrm{~N} 15 / 3$.

5: Ph. 1, J28/2.

6: Ph. $1, \mathrm{U} 32 / 3$.

7: Ph. 1, V41/4.

8: Ph. 1, Y14/0.

9: Ph. 1, Y36/1.

10: $\mathrm{Ph} .1, \mathrm{~T} 52 / 1$.

11: Ph. 1, D23/2.

12: Ph. $1, \mathrm{R} 34 / 0$.

13: Ph. $1, \mathrm{~V} 24 / 0$.

14: $\mathrm{Ph} .1, \mathrm{~V} 42 / 4$.

15: Ph. 1, H24/0.

Figures 16, 17 Polysolenia (?)

16: Ph. 1, R15/2.

17: Ph. 1, V13/0. 
PLATE 1B

离

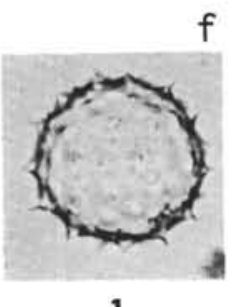

1

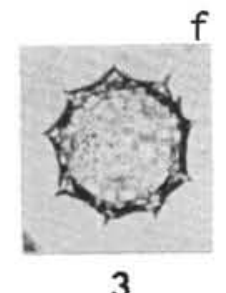

3

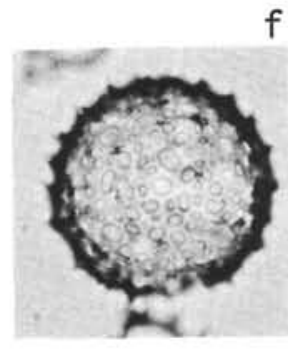

2
ํํำ

Q

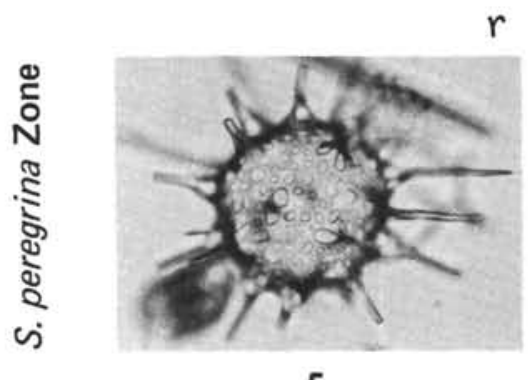

5

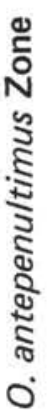

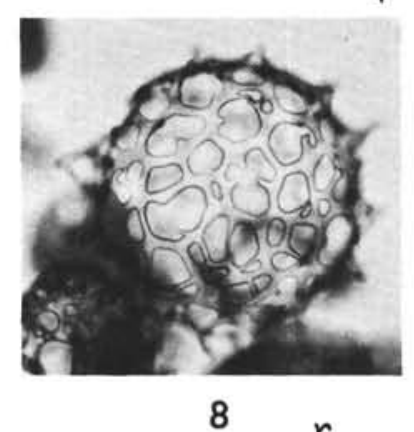

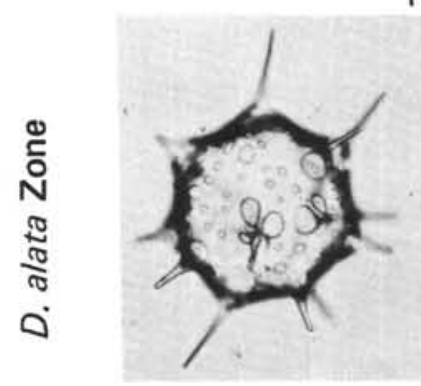

12

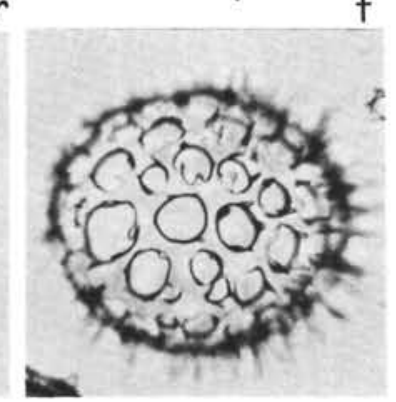

13

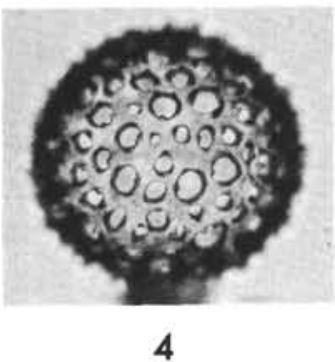

$r$

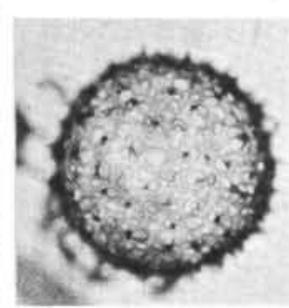

6

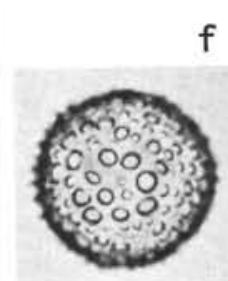

7

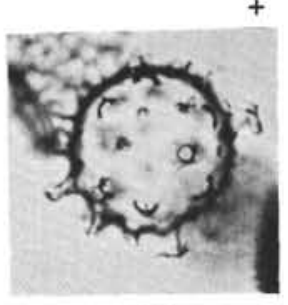

16

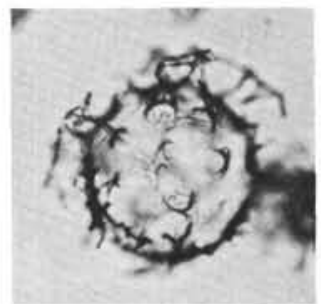

17
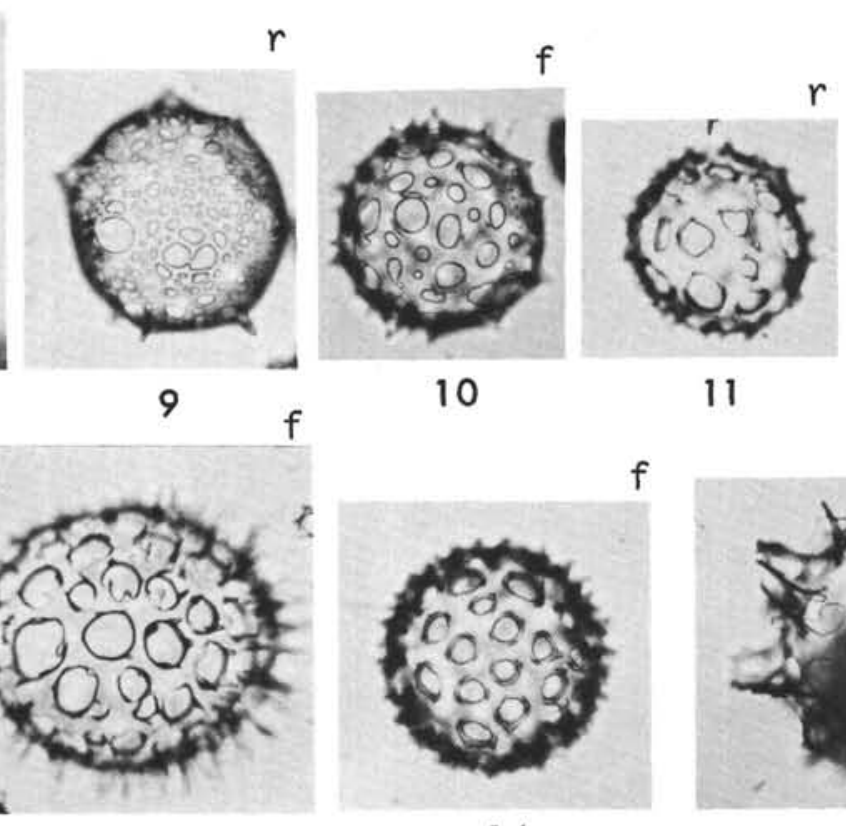

14

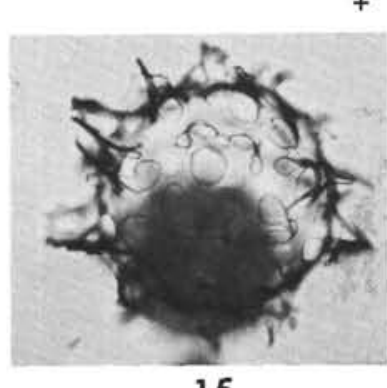

15 
PLATE 1C

Figures 1,2 Siphonosphaera spp.

1: Ph. 1, Q27/4 (150X).

2: Ph. 1, J52/4 (150X).

Figures 3, $4 \quad$ Siphonosphaera (?)

3: Ph. 1, T52/0 (150X).

4: Ph. 1, F48/1 (150X).

Figures 5-7 Ommatartus tetrathalamus (Haeckel)

5: Ph. 1, X44/2 (95X).

6: $\mathrm{Ph} .1, \mathrm{P} 51 / 2(95 \mathrm{X})$.

7: Ph. 1, K52/2 (95X).

Figures 8-10 Ommatartus penultimus (Riedel)

8: Sl. $1,018 / 0(95 \mathrm{X})$.

9: Ph. 1, H17/1 (95X).

10: $\mathrm{Ph} .1, \mathrm{~S} 40 / 3(95 \mathrm{X})$.

Figures 11, 12 Ommatartus antepenultimus Riedel and Sanfilippo 11: Sl. 1, K23/0 (95X).

12: Sl. 1, G47/0 (95X).

Figures 13, 14 Cannartus laticonus Riedel

13: Sl. $1, \mathrm{~N} 49 / 3(95 \mathrm{X})$.

14: Sl. $1, \mathrm{~N} 24 / 4(95 \mathrm{X})$.

Figures 15, 16 Cannartus (?) sp. aff. C. (?) petterssoni Riedel and Sanfilippo

15: Sl. $1, \mathrm{~K} 42 / 4(95 \mathrm{X})$.

16: Ph. 1, X21/0 (95X).

Figures 17, 18 Ommatartus hughesi (Campbell and Clark)

17: $\mathrm{Ph} .1, \mathrm{Q} 17 / 2(95 \mathrm{X})$.

18: Sl. 1, E42/1 (95X).

Figures 19, 20 Cannartus (?) petterssoni Riedel and Sanfilippo 19: Ph. 1, E39/0 (95X).

20: Sl. 1, L38/4 (95X). 
Plate 1C
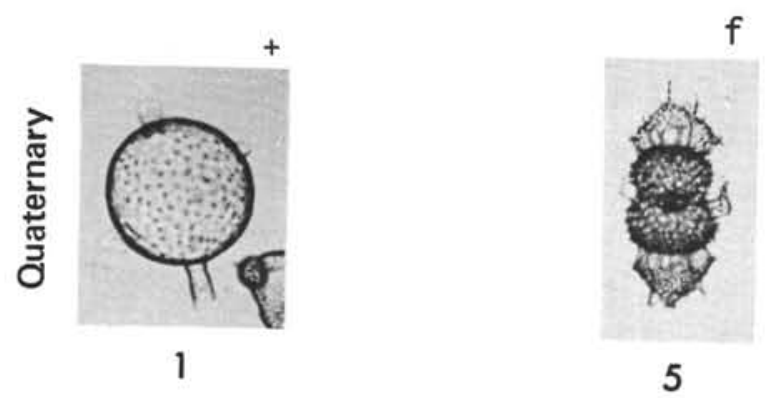

을
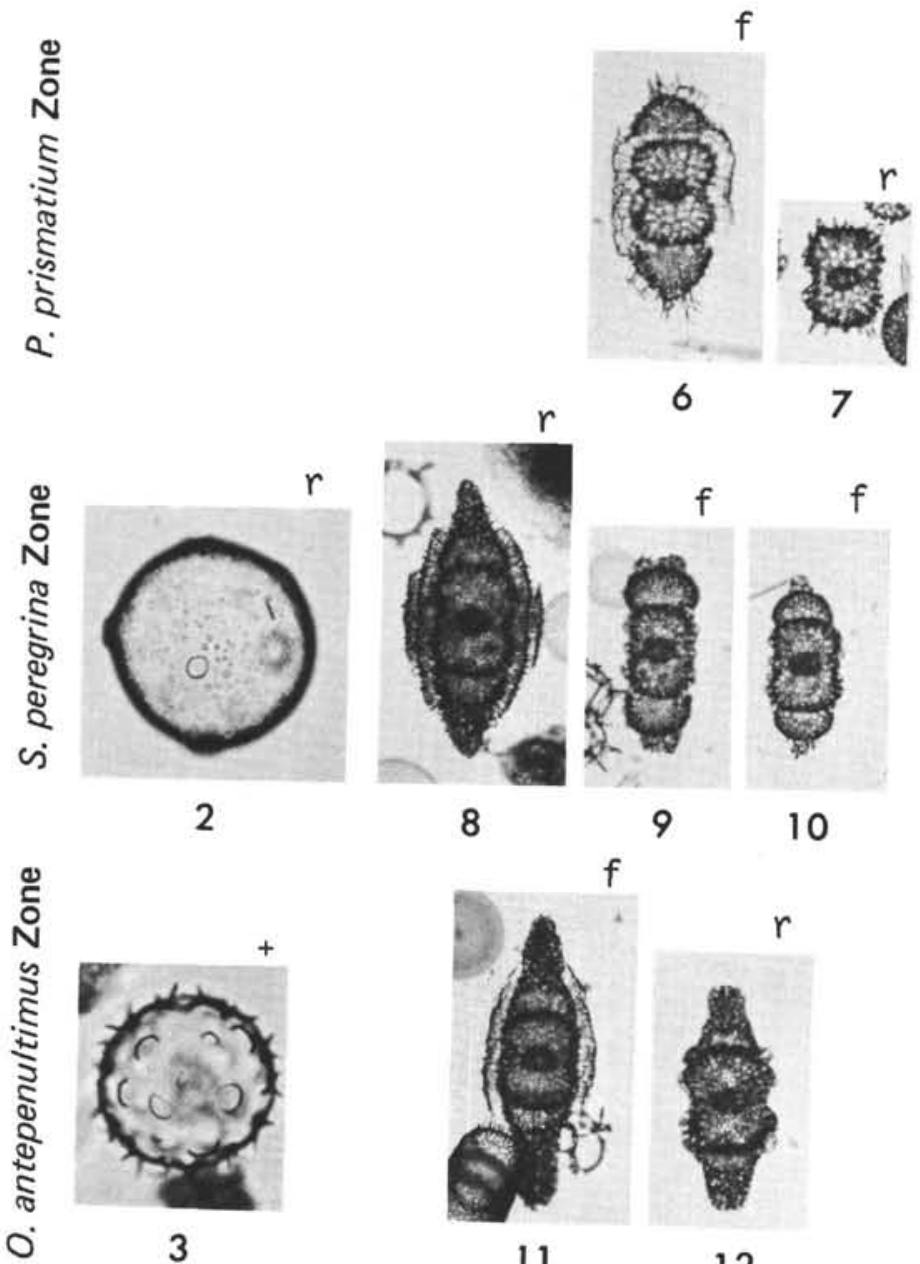

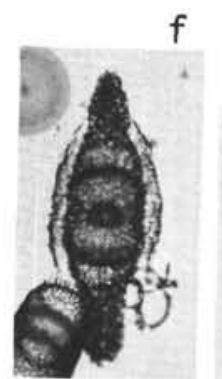

11

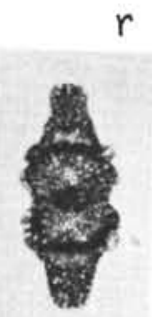

12

C

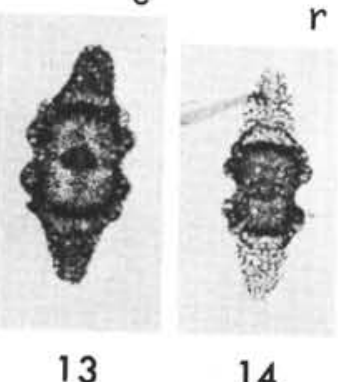

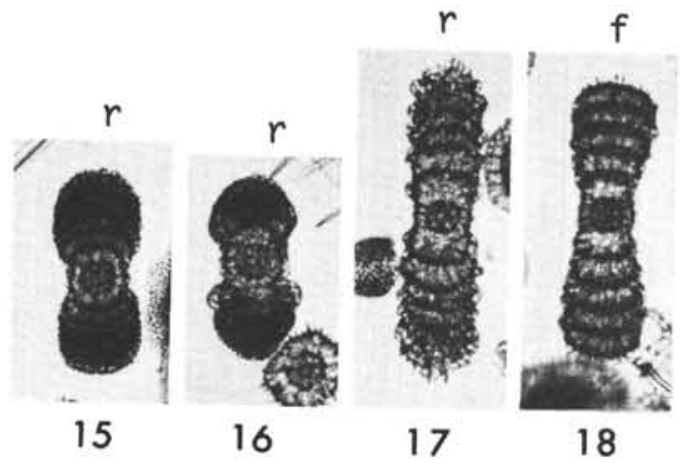

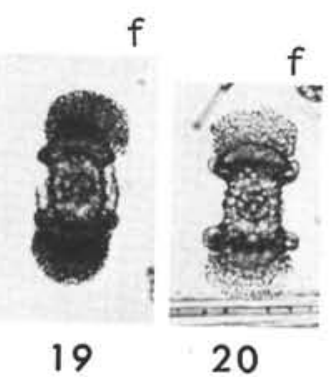


PLATE 1D

(Magnification 95X)

Figure 1

Figures 2-4

Cannartus sp. S1. 1, D12/3.

Spongaster tetras Ehrenberg

2: Sl. $1, \mathrm{X} 53 / 2$.

3: Sl. $1, \mathrm{Q} 14 / 1$.

4: SI. $1, \mathrm{~S} 35 / 2$.

Figures 5-7 Spongaster pentas Riedel and Sanfilippo

5: $66.1-3-3,25-27 \mathrm{~cm}, \mathrm{Sl} .1, \mathrm{D} 36 / 0$.

6: Sl. $1, \mathrm{M} 15 / 2$.

7: Sl. $1, \mathrm{R} 51 / 0$.

Figures 8-10 Spongaster klingi Riedel and Sanfilippo n. sp.

8: Sl. $1, \mathrm{~W} 17 / 0$.

9: Sl. $1, \mathrm{P} 18 / 4$.

10: Cse. $1, \mathrm{~F} 52 / 3$.

Figures 11, 12 Spongaster sp. (?)

11: Sl. $1, \mathrm{D} 47 / 2$.

12: Ph. $1, \mathrm{~V} 46 / 4$.

Figures 13, 14 Spongodiscids, gen. et sp. indet.

13: Cse. 1, K51/0.

14: Cse. 1, K20/3. 
PLATE 1D

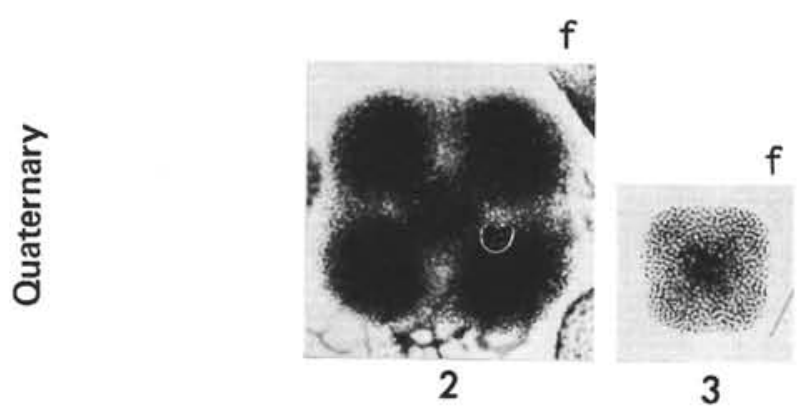

ํํำ

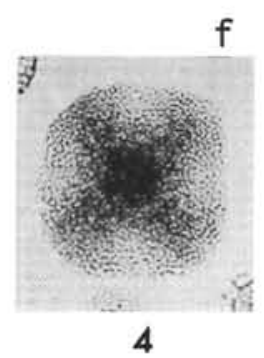

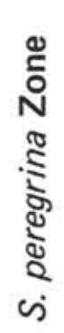
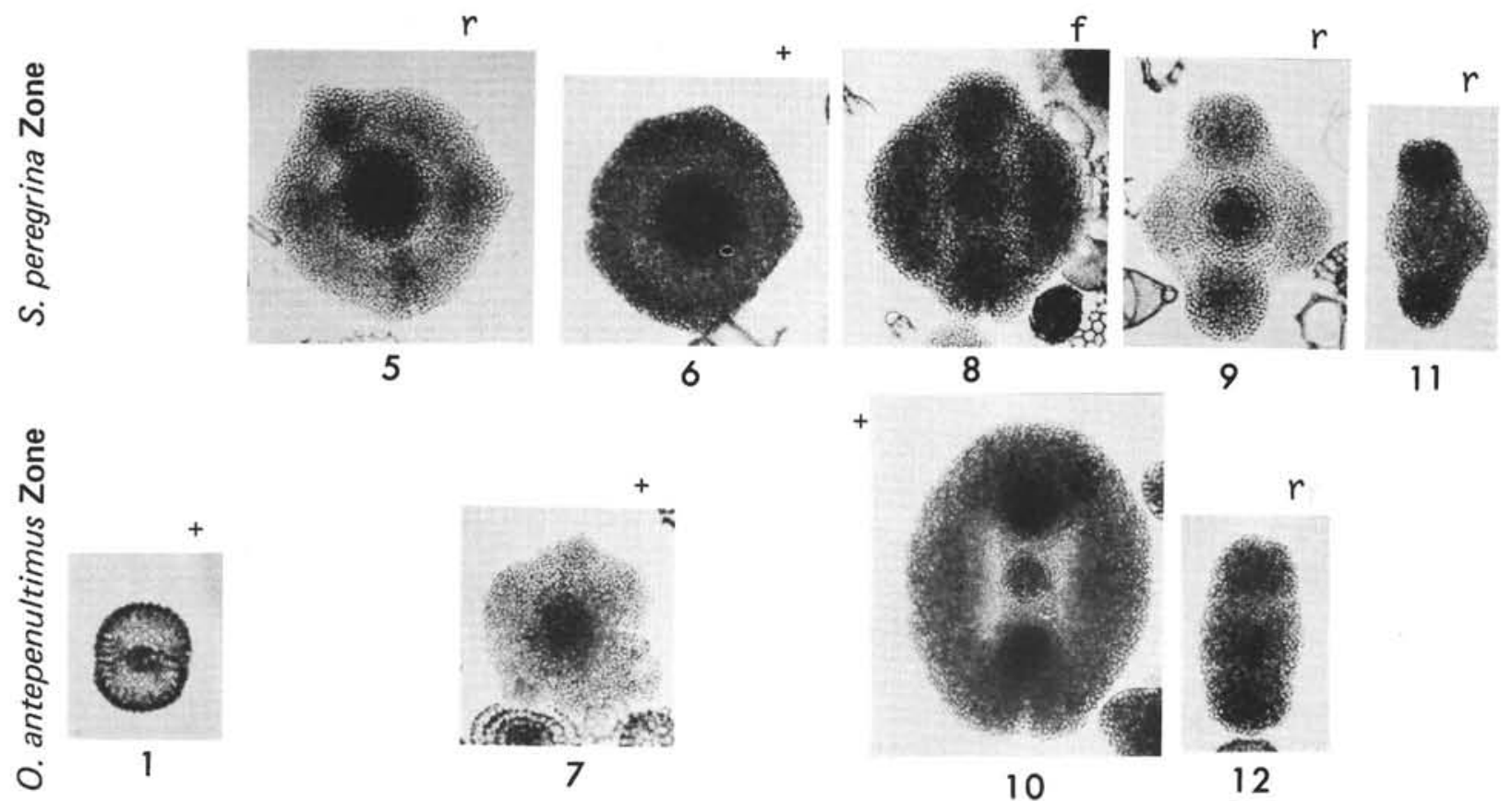

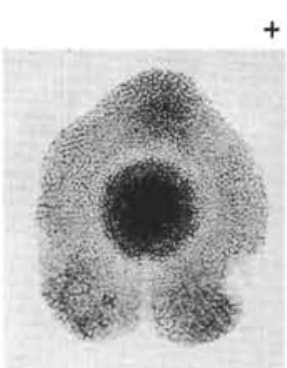

13

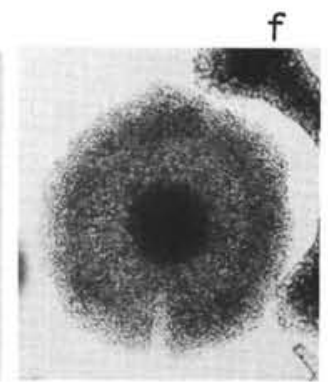

14 
PLATE 1E

Figures 1,2 Dictyocoryne ontongensis Riedel and Sanfilippo, n. sp. 1: Cse. 1, Q31/4 (95X).

2: Cse. 1, E39/0 (95X).

Figure $3 \quad$ Liriospyris elevata Goll Sl. 1, W29/0 (150X).

Figures 4-6 Cyclampterium (?) neatum Sanfilippo and Riedel 4: Cse. 1, E37/4 (80X).

5: $66.1-3-1,25-27 \mathrm{~cm}$, Cse. $1, \mathrm{~V} 37 / 2(80 \mathrm{X})$.

6: $66.1-3-3,25-27 \mathrm{~cm}$, Cse. 1, F31/4 (80X).

Figure $7 \quad$ Cyclampterium (?) brachythorax Sanfilippo and Riedel Cse. 1, M28/0 (80X).

Figures 8-10 Cyclampterium (?) tanythorax Sanfilippo and Riedel

8: 66.1-6-6, 25-27 cm, Cse. 1, E33/4 (80X).

9: $66.1-7-3,70-72 \mathrm{~cm}$, Cse. $1, \mathrm{R} 35 / 1$ (80X).

10: $66.1-7-5,25-27 \mathrm{~cm}$, Cse. 1, B20/4 (80X). 
PLATE 1E

竎

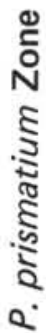

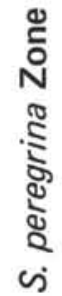
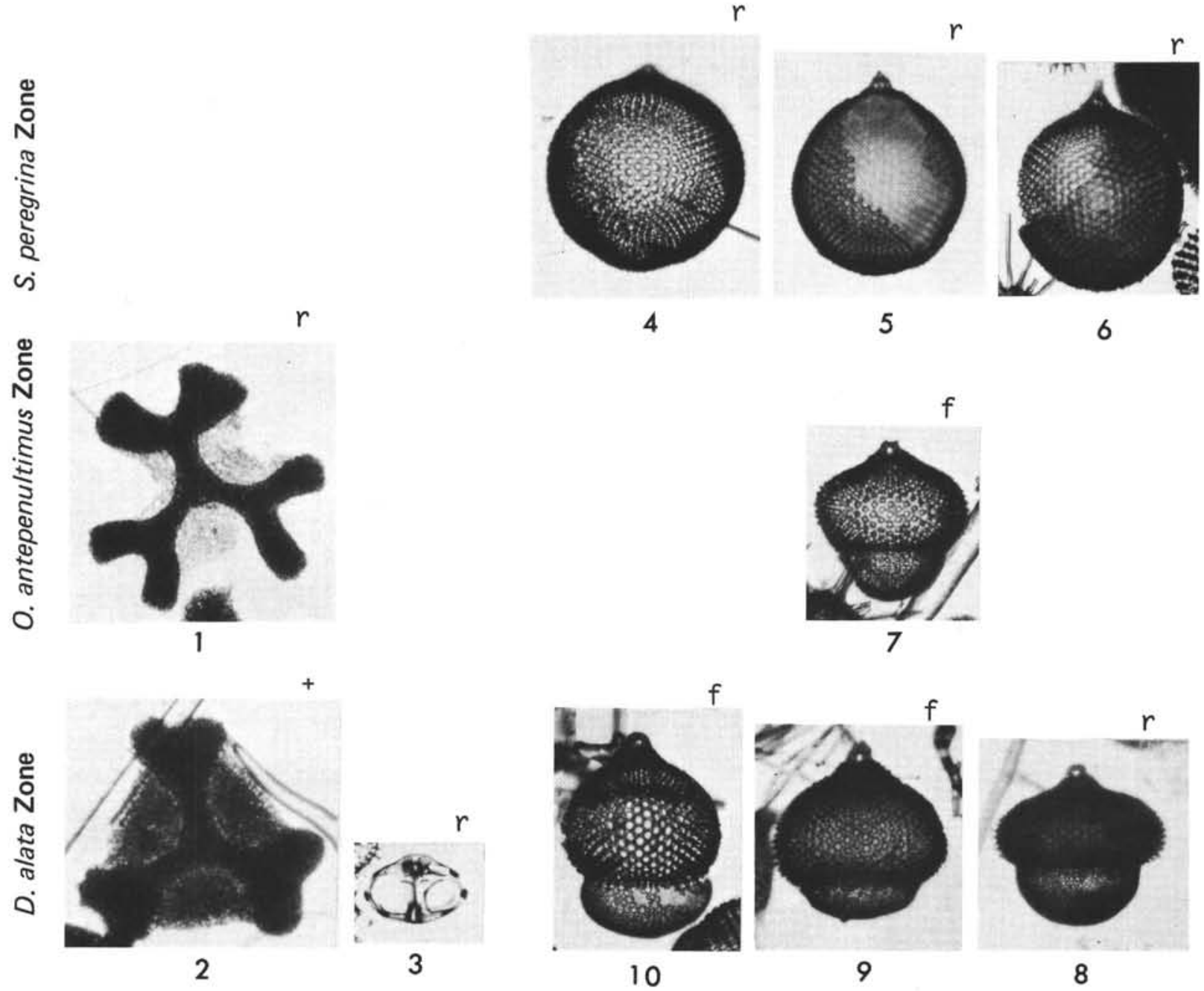
PLATE $1 \mathrm{~F}$

(Magnification 150X)

Figure $1 \quad$ Cyrtocapsella japonica (Nakaseko)

Sl. 1, V25/0.

Figures 2-4 Stichocorys peregrina (Riedel)

2: Ph. 1, W36/0.

3: Ph. $1, \mathrm{~T} 24 / 3$.

4: Ph. 1, U47/3.

Figures 5-7 Stichocorys delmontensis (Campbell and Clark)

5: Sl. $1, \mathrm{~L} 16 / 1$.

6: Sl. $1, \mathrm{P} 46 / 0$.

7: S1. $1, \mathrm{~L} 27 / 2$.

Figure $8 \quad$ Lithopera thornburgi Sanfilippo and Riedel Ph. 1, T15/0.

Figure $9 \quad$ Lithopera baueri Sanfilippo and Riedel Ph. 1, X34/2.

Figures 10-13 Lithopera bacca Ehrenberg

10: Sl. $1, \mathrm{~N} 24 / 3$.

11: Sl. $1, \mathrm{Y} 30 / 1$.

12: Sl. $1, \mathrm{H} 20 / 2$.

13: Sl. $1, \mathrm{H} 25 / 2$.

Figures 14, 15 Lithopera neotera Sanfilippo and Riedel 14: Ph. 1, 016/2.

15: Sl. 1, L27/2. 
PLATE 1F

竡

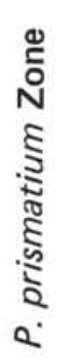
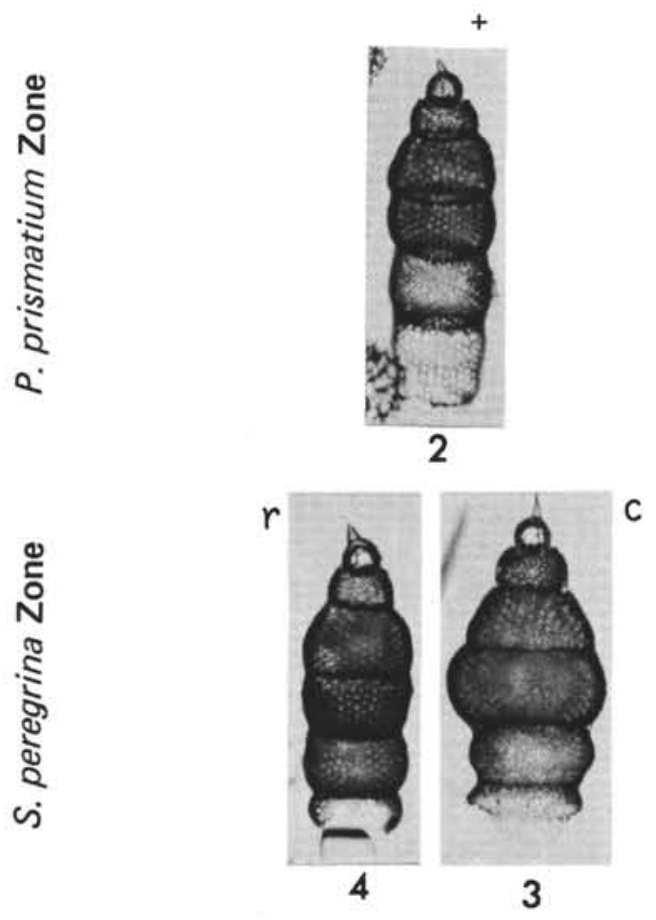

ปั.

a
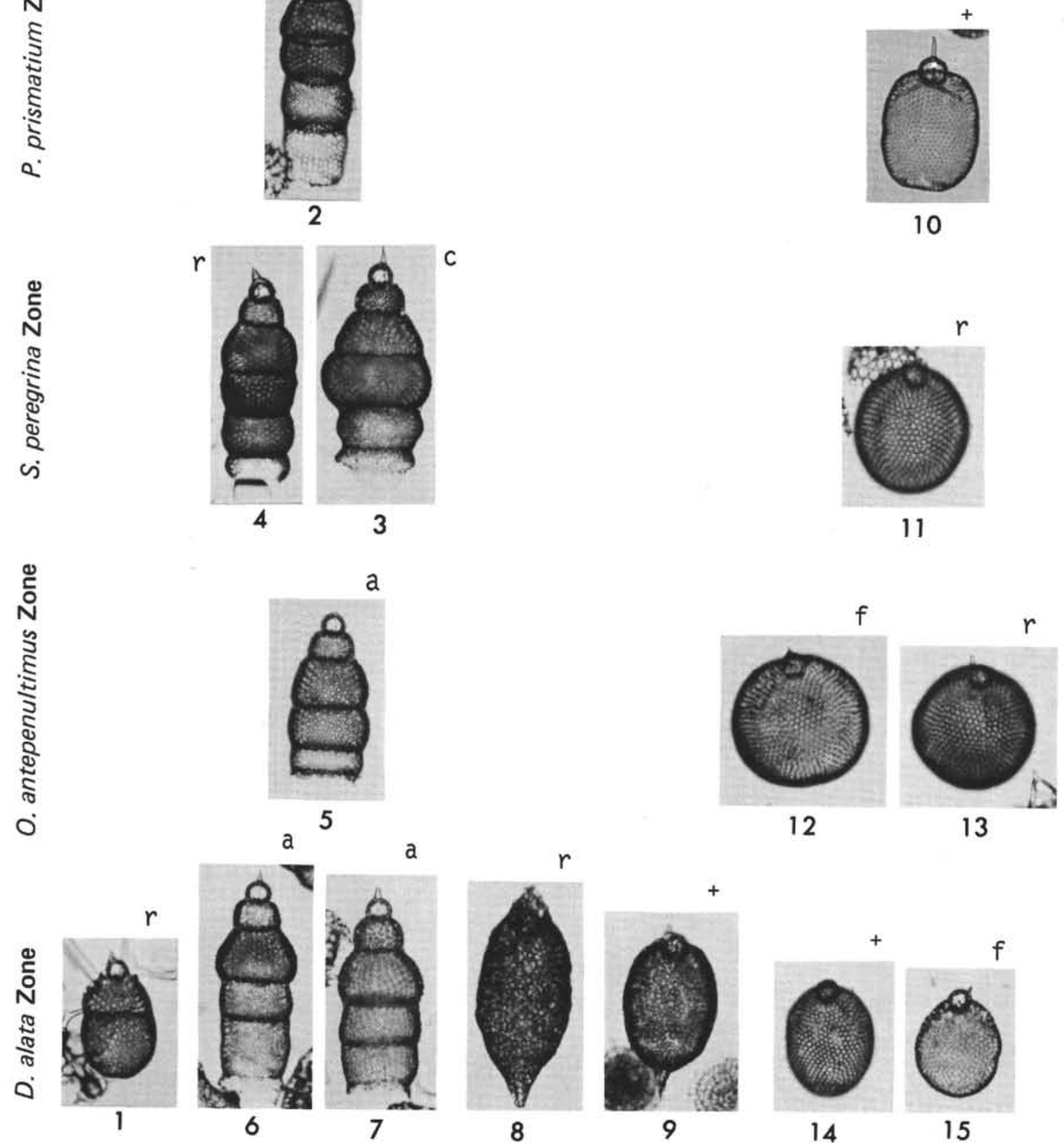

11

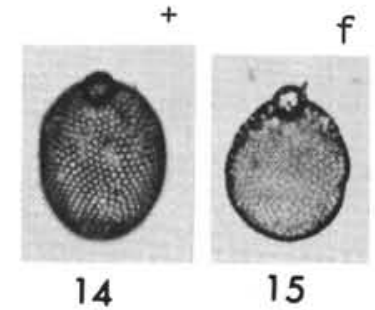


PLATE $1 G$

Figures 1-6, Carpocanistrum spp.

7 (?), 8-13, 1: Sl. 1, U26/4 (150X).

14 (?), 15 (?) 2: S1. $1, \mathrm{Q} 41 / 1(150 \mathrm{X})$.

3: SI. 1, Q46/3 (150X).

4: Sl. 1, H19/2 (150X).

5: Sl. $1, \mathrm{X} 24 / 2(150 \mathrm{X})$.

6: Sl. 1, U34/2 (150X).

7: Sl. $1, \mathrm{U} 36 / 3(150 \mathrm{X})$.

8: Sl. 1, S18/0 (150X).

9: Sl. 1, 035/0 (150X).

10: Sl. 1, W17/3 (150X).

11: Sl. 1, R37/3 (150X).

12: Sl. $1, \mathrm{M} 43 / 2(150 \mathrm{X})$

13: Sl. 1, U24/1 (150X).

14: Sl. $1, \mathrm{M} 44 / 0(150 \mathrm{X})$

15: Sl. $1, \mathrm{~W} 44 / 4(150 \mathrm{X})$

Figure $16 \quad$ Carpocanopsis cristatum (Carnevale) (?) Sl. 1, R14/4 (150X).

Figures 17, 18 Calocycletta sp.

17: $\mathrm{Ph} .1, \mathrm{P} 38 / 1$ (95X).

18: Ph. 1, E34/1 (95X).

Figures 19-24 Spirocyrtis sp. aff. S. scalaris Haeckel

19: Ph. 1, R53/0 (150X).

20: Ph. 1, O24/0 (150X).

21: Sl. $1, \mathrm{Q} 42 / 0(150 \mathrm{X})$.

22: Ph. 1, G37/3 (150X).

23: Ph. 1, Y42/2 (150X).

24: Ph. 1, P20/3 (150X).

Figures 25-27 Spirocyrtis scalaris Haeckel

25: Sl. 1, Q38/4 (150X).

26: Ph. 1, E36/1 (150X).

27: Sl. 1, W36/3 (150X). 
PLATE 1G
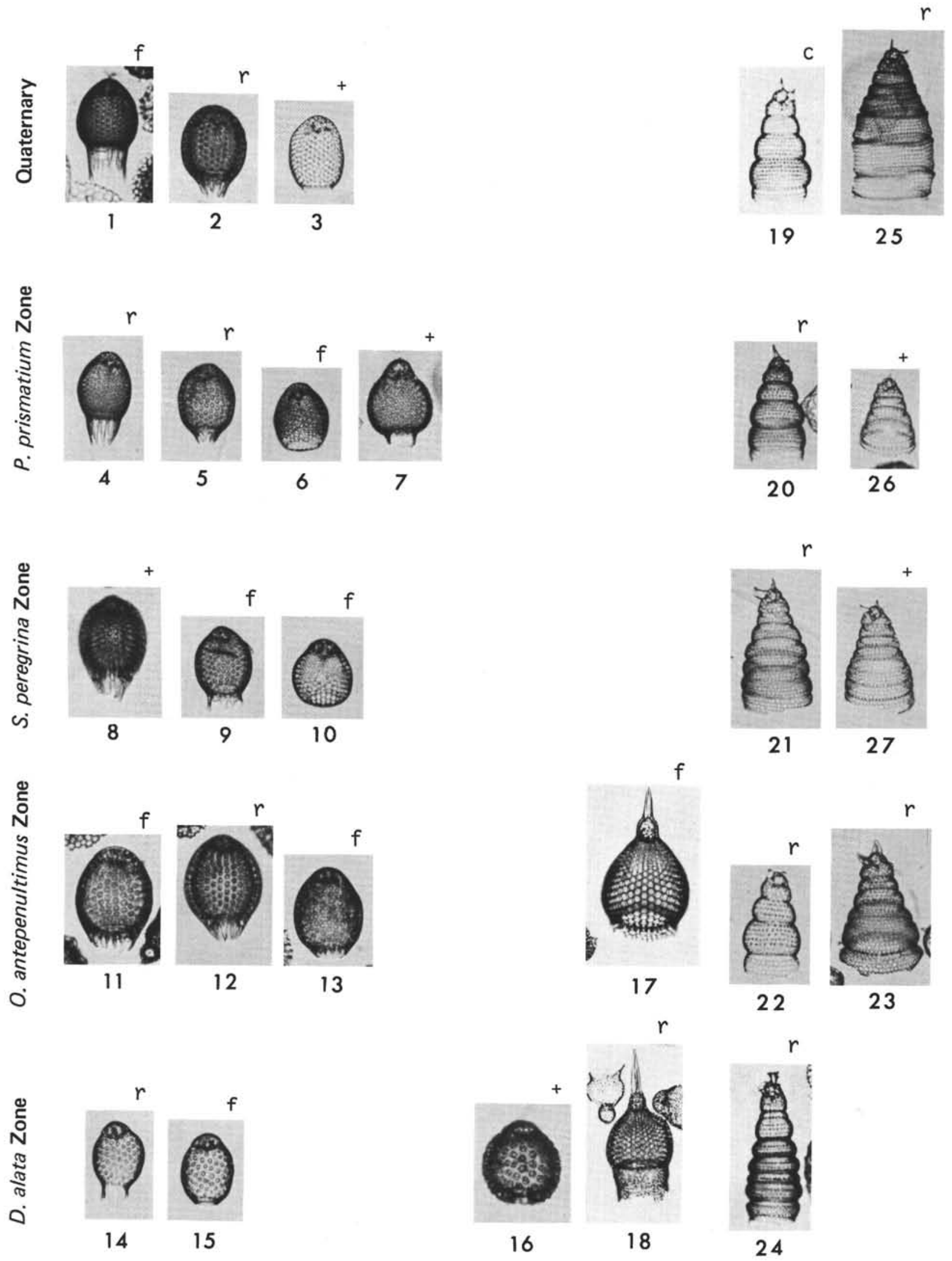


\section{PLATE $1 \mathrm{H}$}

(Magnification 150X)

Figures 1-3 Artostrobium doliolum Riedel and Sanfilippo, n. sp.

1: $\mathrm{Ph} .1, \mathrm{~K} 17 / 0$.

2: $\mathrm{Ph} .1, \mathrm{Y} 28 / 0$.

3: Ph. $1, \mathrm{X} 43 / 0$.

Figure 4 Artostrobium sp. aff. A. doliolum Riedel and Sanfilippo, n. sp.

Ph. 1, Y16/2.

Figures 5-8 Artostrobium auritum (Ehrenberg) group

5: $\mathrm{Ph} .1, \mathrm{U} 48 / 1$.

6: $\mathrm{Ph} .1,050 / 2$.

7: $\mathrm{Ph} .1, \mathrm{R} 26 / 0$.

8: Ph. $1, \mathrm{~T} 40 / 0$.

Figures 9-17 Artostrobium miralestense (Campbell and Clark)

9: Ph. 1, E36/0.

10: $\mathrm{Ph} .1, \mathrm{~V} 35 / 3$.

11: Ph. 1, U47/2.

12: Ph. $1, \mathrm{~S} 41 / 1$.

13: Sl. $1, \mathrm{H} 27 / 0$.

14: Sl. $1, \mathrm{H} 48 / 3$.

15: Sl. $1, \mathrm{~V} 51 / 2$.

16: Sl. $1, \mathrm{~N} 52 / 0$.

17: Ph. 1, J23/3.

Figures 18-25 Siphocampe corbula (Harting)

18: Sl. $1, \mathrm{~K} 52 / 2$.

19: $\mathrm{Ph} .1, \mathrm{P} 19 / 0$.

20: Ph. 1, Q26/0.

21: Ph. 1, J40/3.

22: Sl. $1, \mathrm{~S} 39 / 2$.

23: Ph. 1, Q31/3.

24: Sl. $1, \mathrm{~L} 24 / 0$.

25: Ph. 1, L50/3.

Figures 26-28 Siphocampe sp. aff. S. corbula (Harting)

26: Ph. 1, F22/4.

27: Ph. $1, \mathrm{X} 49 / 1$.

28: $\mathrm{Ph} .1, \mathrm{C} 33 / 4$. 
PLATE 1H
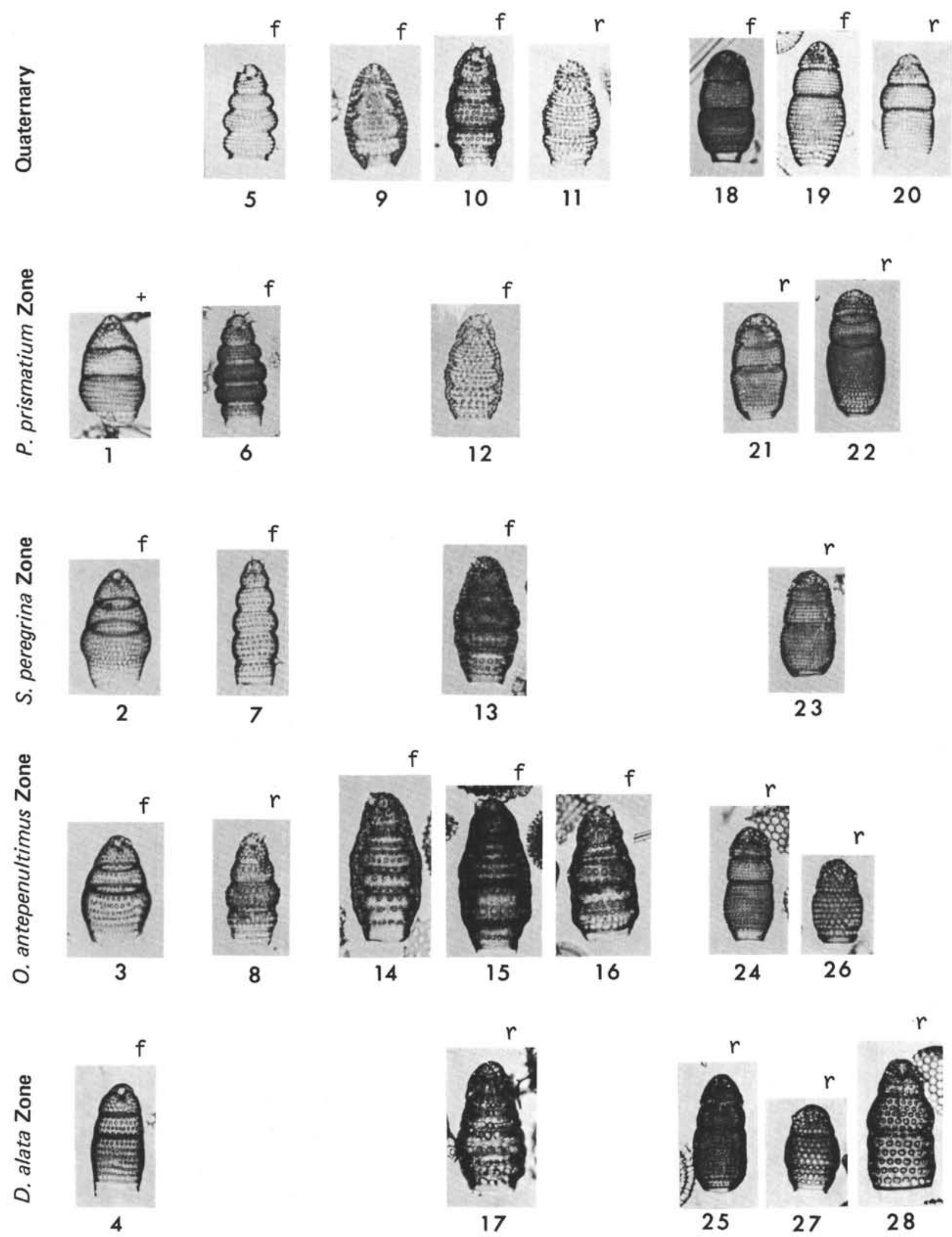
PLATE 1I

(Magnification 150X)

Figures 1-11 Lithomitra lineata (Ehrenberg) group

1: $\mathrm{Ph} .1, \mathrm{~K} 28 / 0$.

2: Sl. 1, J34/0.

3: $\mathrm{Ph} .1, \mathrm{Q} 30 / 4$.

4: Sl. 1, E19/2.

5: S1. $1, \mathrm{Q} 43 / 3$.

6: Sl. $1, \mathrm{H} 20 / 0$.

7: Ph. $1,041 / 3$.

8: Ph. 1, T28/1.

9: Ph. 1, E36/4.

10: Ph. 1, M24/0.

11: Ph. 1, M31/1.

Figure 12 Lithomitra sp. aff. L. lineata (Ehrenberg) group Ph. 1, O24/0.

Figures 13-15 Phormostichoartus corona Haeckel

13: Ph. 1, Y31/0.

14: Ph. 1, M53/2.

15: Ph. 1, Y54/1.

Figure 16 Phormostichoartus sp. aff. P. corona Haeckel (?) Ph. 1, M34/3.

Figures 17-25 Carpocanarium spp.

17: S1. 1, L29/4.

18: Sl. 1, E23/3.

19: Sl. $1, \mathrm{G} 15 / 4$.

20: SI. 1, 016/0.

21: Sl. 1, U29/2.

22: Sl. 1, V29/0.

23: $66.1-4-1,110-111 \mathrm{~cm}$, Sl. 1, Q44/4.

24: Sl. 1, Q18/3.

25: Sl. $1, \mathrm{Y} 14 / 4$. 
PLATE 11
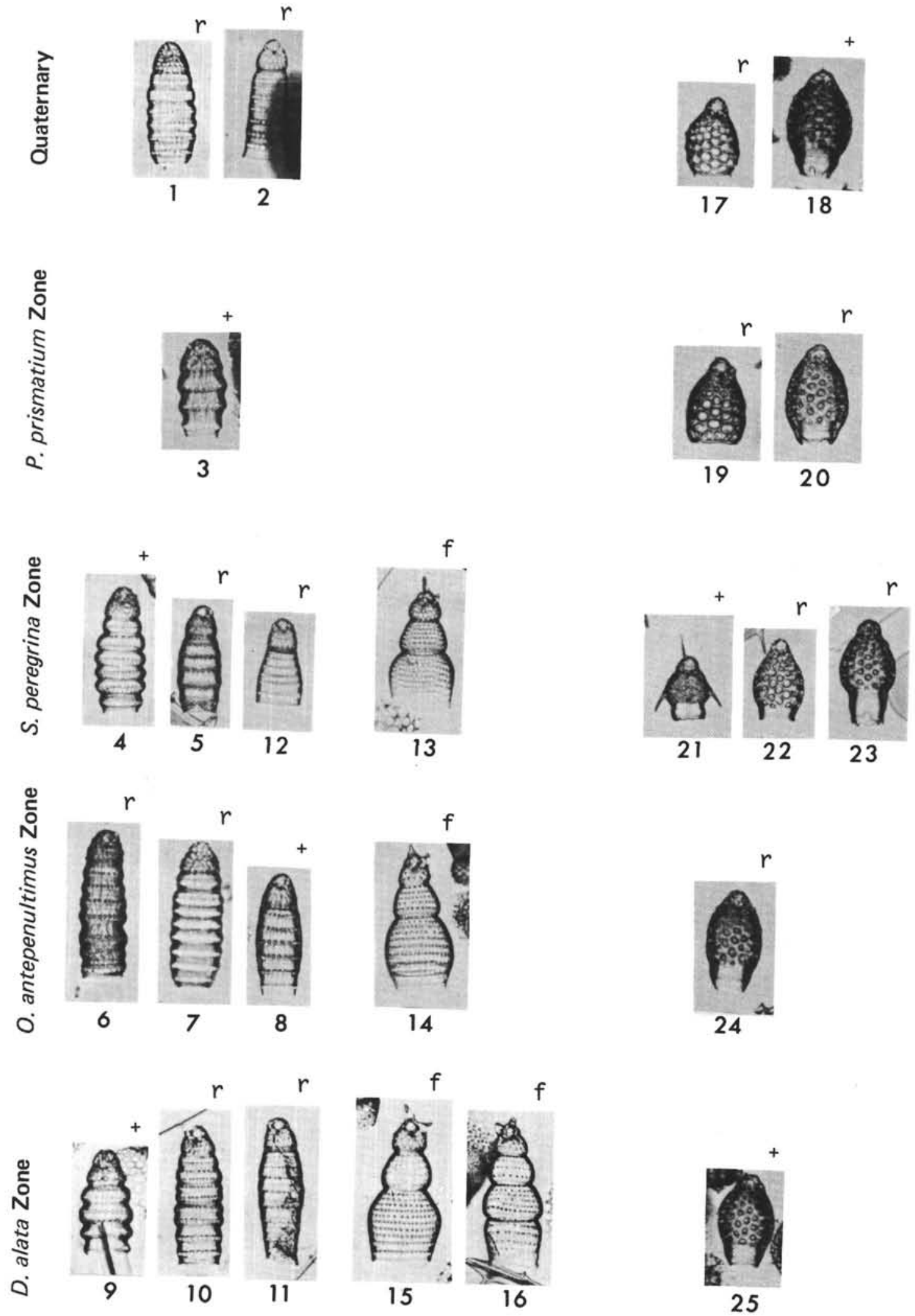
PLATE 1J

(Magnification 150X)

Figures 1-11 Botryocyrtis spp.

1: S1. 1, S53/2.

2: S1. 1, C29/0.

3: S1. $1, \mathrm{H} 33 / 3$.

4: Sl. 1, Q40/1.

5: Sl. 1, Q39/4.

6: Sl. $1, \mathrm{~K} 40 / 0$.

7: Sl. 1, T20/4.

8: Sl. $1,051 / 1$.

9: Sl. 1, L41/0.

10: Sl. $1, \mathrm{R} 34 / 0$.

11: Sl. $1, \mathrm{~V} 35 / 0$.

Figures 12-16 Acrobotrys spp.

12: Sl. $1, \mathrm{X} 25 / 3$.

13: SI. $2,020 / 0$.

14: Sl. 1, V24/2.

15: Sl. 1, M21/3.

16: Sl. $1, \mathrm{H} 38 / 3$.

Figures 17, 18 Gen. et sp. indet.

17: Sl. $1, \mathrm{X} 24 / 0$.

18: Sl. $2, \mathrm{~K} 33 / 0$.

Figures 19, 20 Acrobotrys tritubus Riedel

19: $66.1-3-3,25-27 \mathrm{~cm}$, Sl. 1, N29/3.

20: Sl. 1, P52/3.

Figures 21-26 Botryopyle dictyocephalus Haeckel group

21: Sl. 1, D20/0.

22: Sl. 1, U30/1.

23: S1. 1, F45/0.

24: Sl. 1, Q34/1.

25: S1. 1, T31/2.

26: Sl. 1, K48/0.

Figures 27-31 Centrobotrys thermophila Petrushevskaya 27: Sl. 1, D20/4.

28: Sl. 1, 032/0.

29: Sl. 1, Q34/4.

30: Sl. 1, Q24/0.

31: Sl. 1, E33/4. 
PLATE 1J
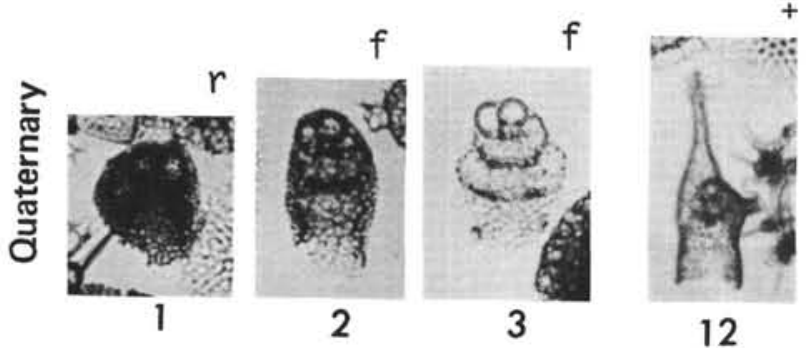

12
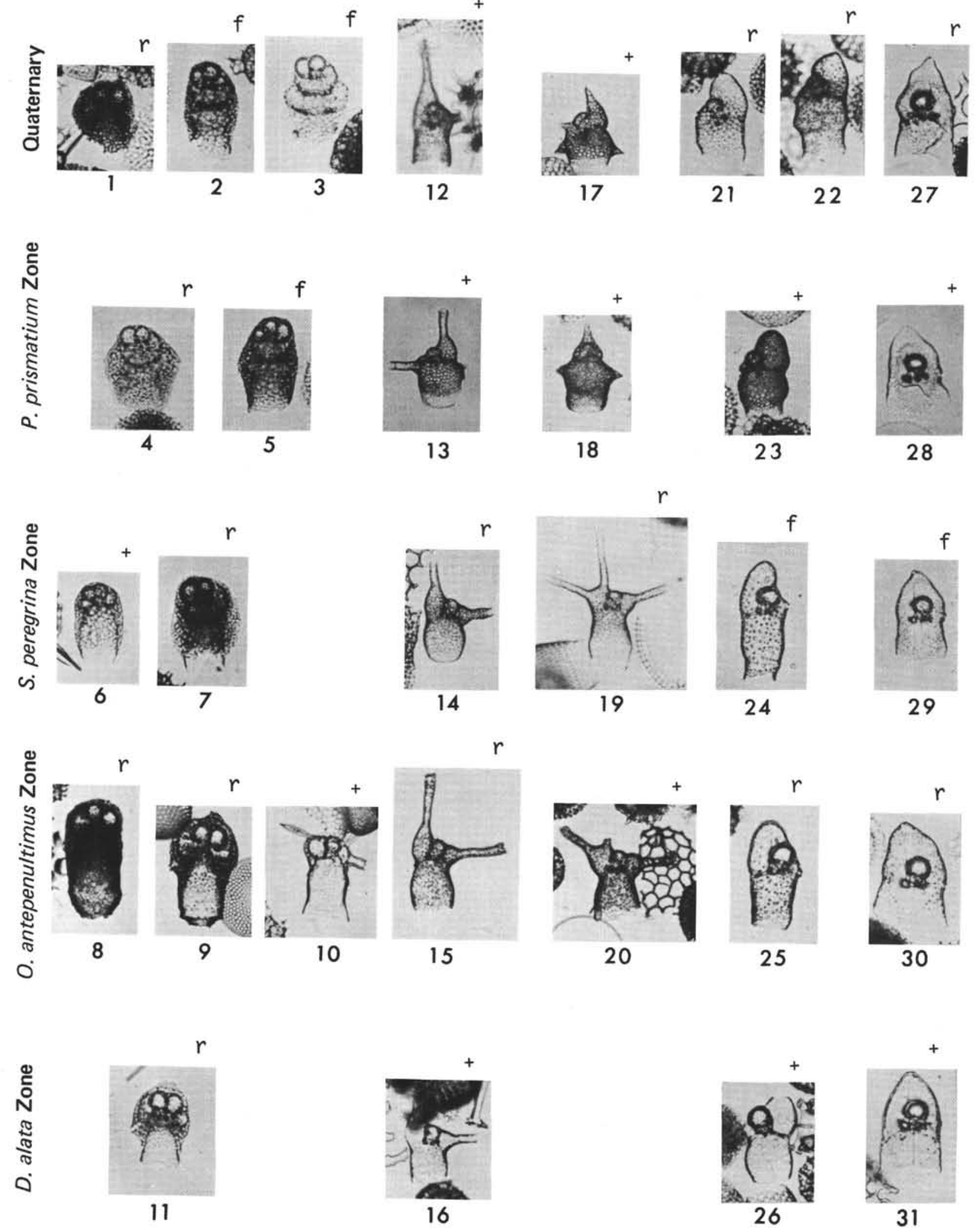
PLATE 2A

(Magnification 150X)

Figures 1,2 Collosphaera spp.

1: Ph. $1, \mathrm{~T} 40 / 2$.

2: Ph. 1, E43/2.

Figure 3

Collosphaera (?)

Ph. 1, Y29/2.

Figures 4-10 Solenosphaera spp.

4: $\mathrm{Ph} .1, \mathrm{M} 27 / 2$.

5: Ph. $1, \mathrm{~N} 35 / 0$.

6: $\mathrm{Ph} .1, \mathrm{D} 8 / 0$.

7: Ph. 1, N20/1.

8: Ph. $1,037 / 3$.

9: Sl. $1, \mathrm{H} 12 / 2$.

10: Sl. 1, Y38/3.

Figures 11-15 Polysolenia spp.

11: $\mathrm{Ph} .1, \mathrm{E} 50 / 1$.

12: Ph. $1, \mathrm{~V} 47 / 0$.

13: $\mathrm{Ph} .1, \mathrm{P} 35 / 0$.

14: Sl. $1, \mathrm{Y} 48 / 0$.

15: Ph. 2, Y26/0. 

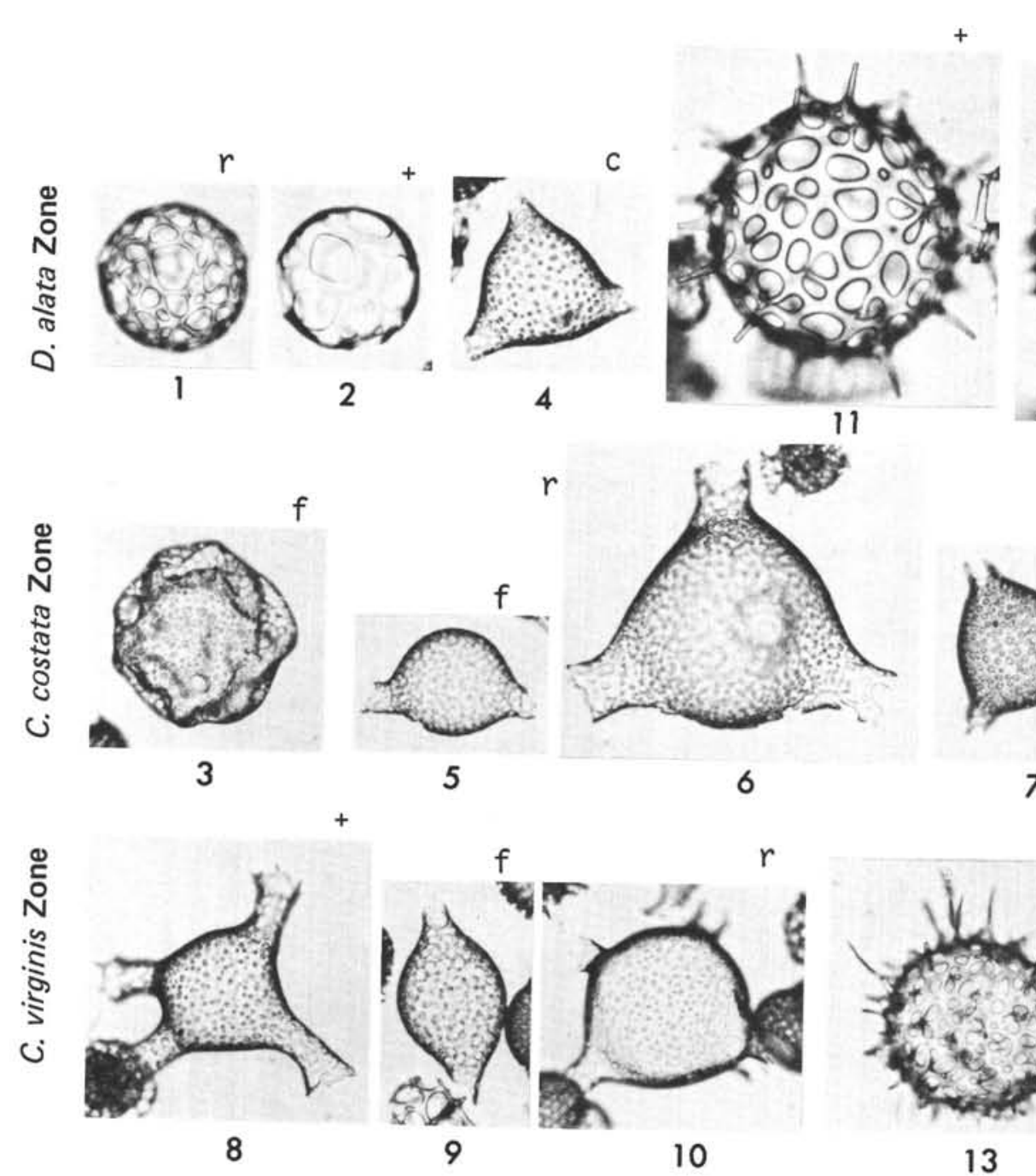

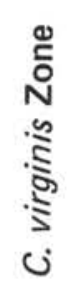

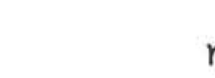

$r$
11 b.

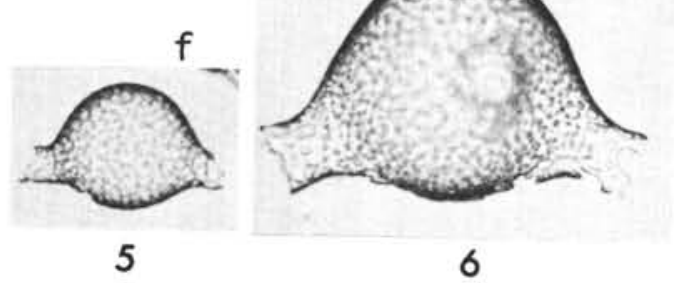

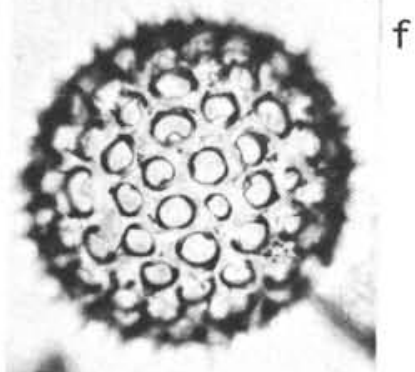

12
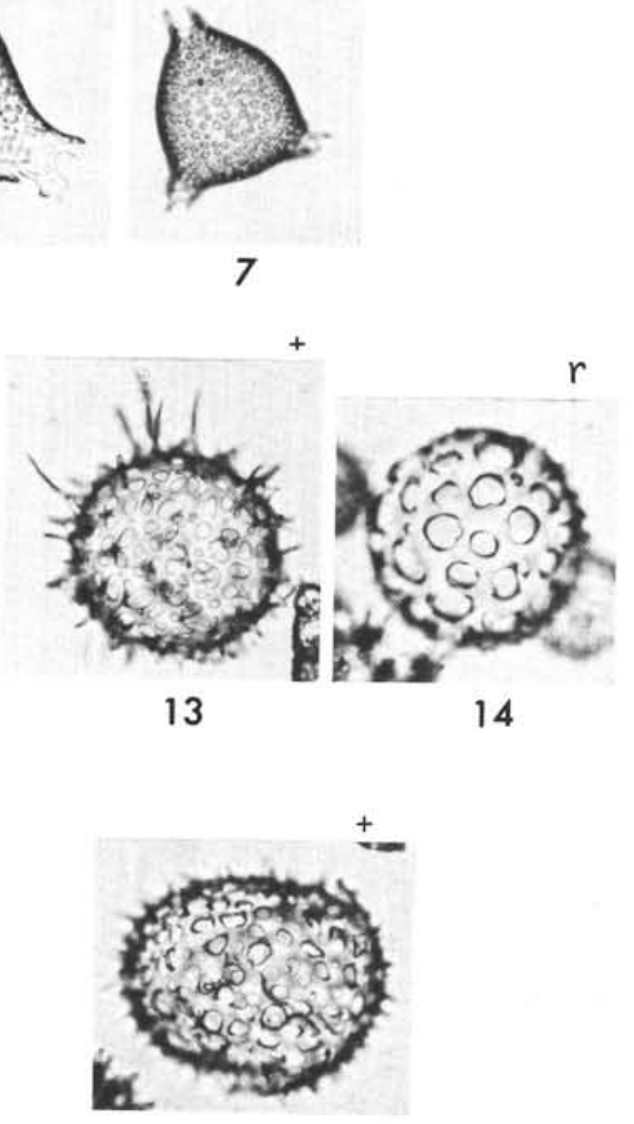

15

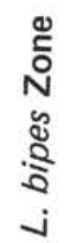


PLATE 2B

Figures 1-4 Polysolenia (?)

1: Ph. 1, E45/4 (150X).

2: Ph. 1, T52/0 (150X).

3: Ph. 1, V33/2 (150X).

4: Ph. 1, 018/4 (150X).

Figure 5 Siphonosphaera sp.

Sl. 1, X44/0 (150X).

Figures 6-8 Tribonosphaera sp.

6: Ph. 1, T27/0 (150X).

7: Ph. $1, \mathrm{X} 49 / 3$ (150X).

8: Ph. 1, C6/4 (150X).

Figures 9, 10 Cannartus sp.

9: Ph. 1, V23/4 (95X).

10: Ph. 1, E44/4 (95X). 
PLATE 2B
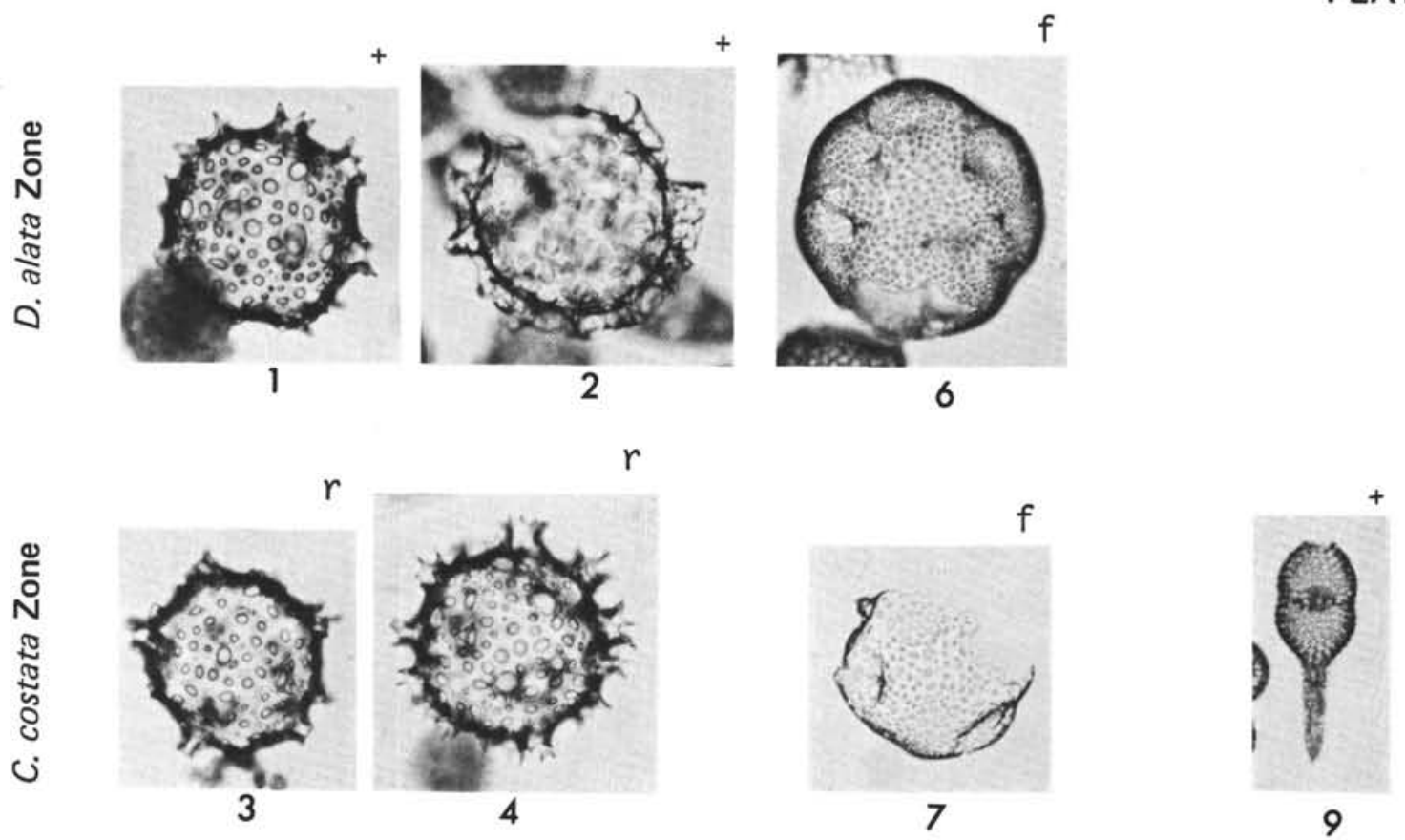

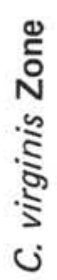
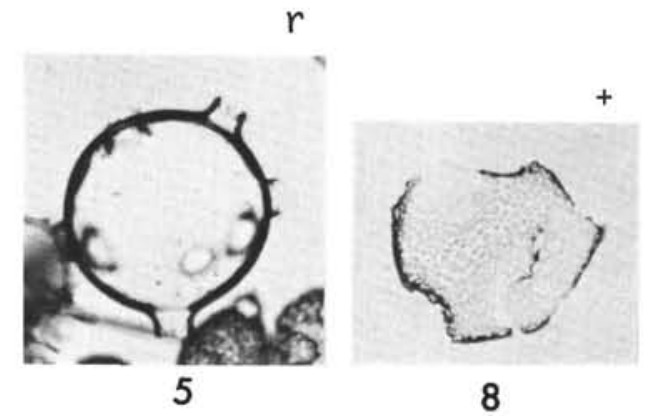

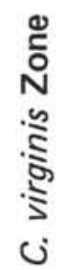

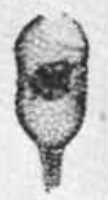

10

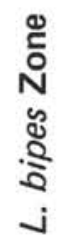




\section{PLATE 2C}

Figures 1-3 Cannartus mammiferus (Haeckel)

1: Ph. 1, Q39/0 (95X).

2: Ph. $1, \mathrm{Y} 18 / 1(95 \mathrm{X})$.

3: Ph. 1, V13/2 (95X).

Figures 4-7 Cannartus violina Haeckel

4: Ph. 1, F37/1 (95X).

5: Ph. 1, J19/1 (95X).

6: Ph. 1, T35/0 (95X).

7: Ph. 1, J25/1 (95X).

Figures 8-10 Cannartus tubarius (Haeckel)

8: Ph. 1, V37/1 (95X).

9: Sl. 1, V29/1 (95X).

10: Ph. 1, G39/4 (95X).

Figures 11-13 Cannartus prismaticus (Haeckel)

11: Ph. 1, S19/0 (95X).

12: Sl. $1, \mathrm{~V} 42 / 1(95 \mathrm{X})$.

13: Ph. 1, T14/4 (95X).

Figure 14 Cannartus (?) sp. aff. C. prismaticus (Haeckel) Sl. 1, S30/1 (95X).

Figure 15 Liriospyris parkerae Riedel and Sanfilippo, n. sp. Ph. 1, Z28/2 (150X).

Figures 16-19 Liriospyris stauropora (Haeckel)

16: Ph. 1, U44/3 (150X).

17: Ph. $1, \mathrm{~N} 33 / 4$ (150X).

18: Sl. $1, \mathrm{~T} 42 / 1(150 \mathrm{X})$.

19: Sl. $1, \mathrm{~V} 13 / 0(150 \mathrm{X})$.

Figures 20-23 Dorcadospyris forcipata (Haeckel)

20: Cse. 2, V27/0 (60X).

21: Cse. $1, \mathrm{C} 17 / 0(60 \mathrm{X})$.

22: Cse. $1, \mathrm{~K} 30 / 1(60 \mathrm{X})$.

23: Cse. 1, L15/0 (60X). 
PLATE 2C
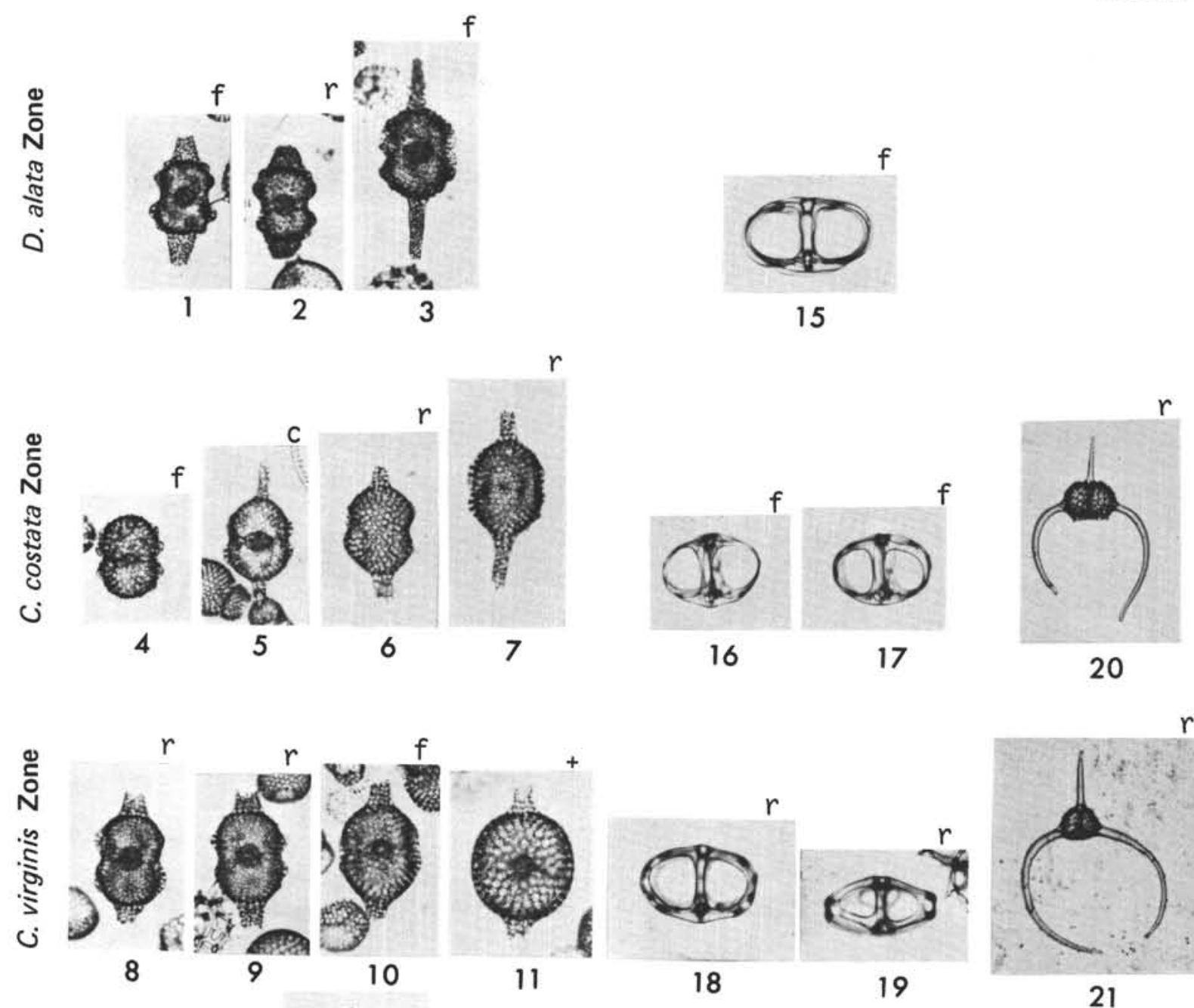

ֻั
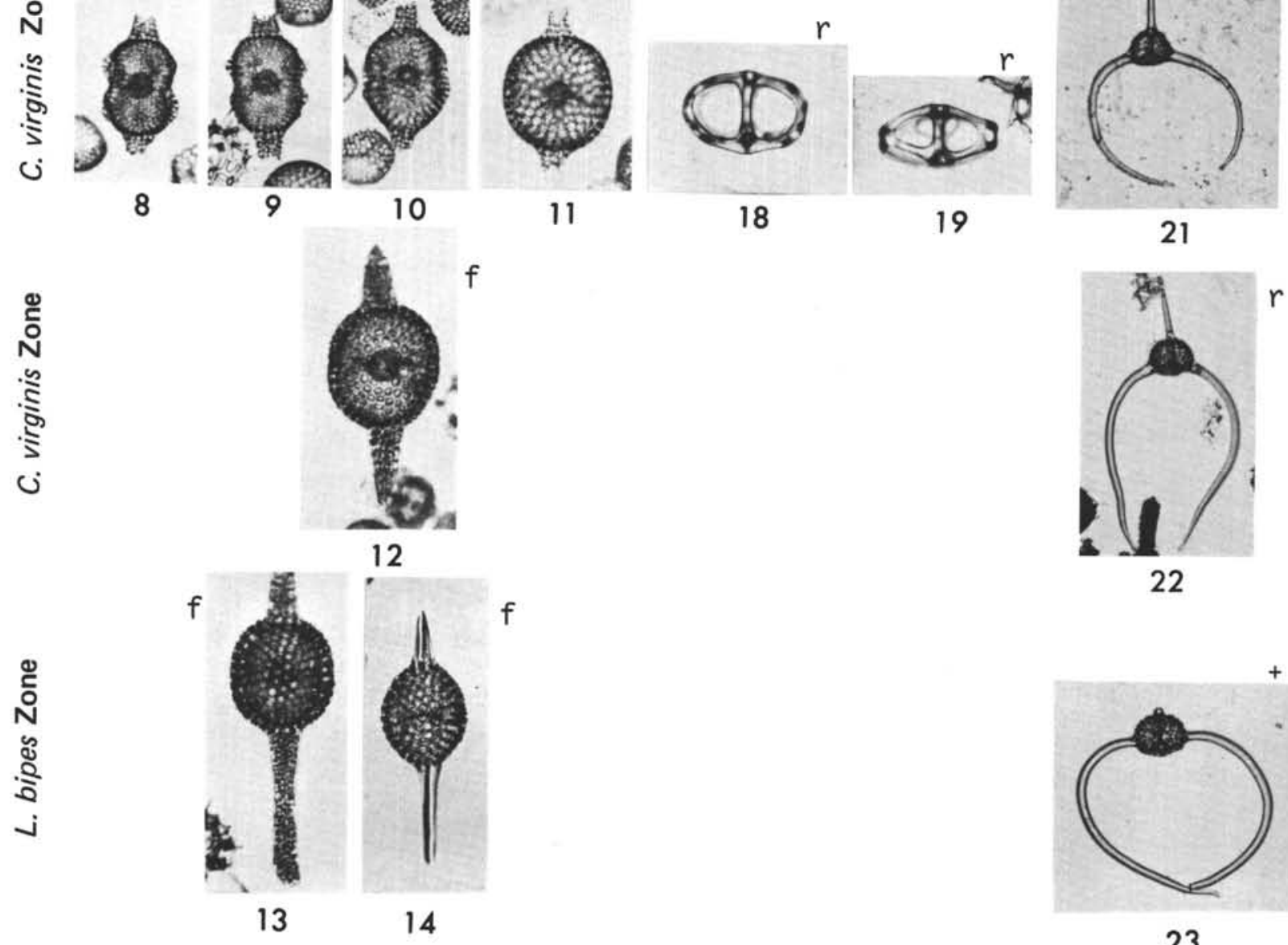


\section{PLATE 2D}

Figure $1 \quad$ Dorcadospyris alata (Riedel)

Cse. 1, E26/1 (60X).

Figures 2, 3 Dorcadospyris dentata Haeckel

2: Cse. $1, \mathrm{~N} 16 / 3(60 \mathrm{X})$.

3: Cse. 1, K16/2 (60X).

Figures 4, 5 Dorcadospyris papilio (Riedel)

4: Cse. 1, J30/0 (60X).

5: Cse. 2, G20/4 (60X).

Figure $6 \quad$ Dorcadospyris ateuchus (Ehrenberg)

Cse. 1, Q28/3 (60X).

Figures 7,8 Cyclampterium (?) tanythorax Sanfilippo and Riedel

7: Cse. 1, E40/1 (80X).

8: Cse. 1, E36/0 (80X).

Figures 9-12 Cyclampterium (?) leptetrum Sanfilippo and Riedel

9: Cse. 2, M27/0 (80X).

10: Cse. 1, G18/2 (80X).

11: 64.1-6-CC, Cse. 1, T23/3 (80X).

12: 64.1-6-CC, Cse. 1, S22/2 (80X).

Figures 13,14 Cyclampterium (?) pegetrum Sanfilippo and Riedel

13: $64.0-7-3,84-86 \mathrm{~cm}$, Cse. $1, \mathrm{~N} 20 / 0$ (80X).

14: $64.0-7-3,84-86 \mathrm{~cm}, \mathrm{Sl} .1, \mathrm{~N} 19 / 2(80 \mathrm{X})$. 

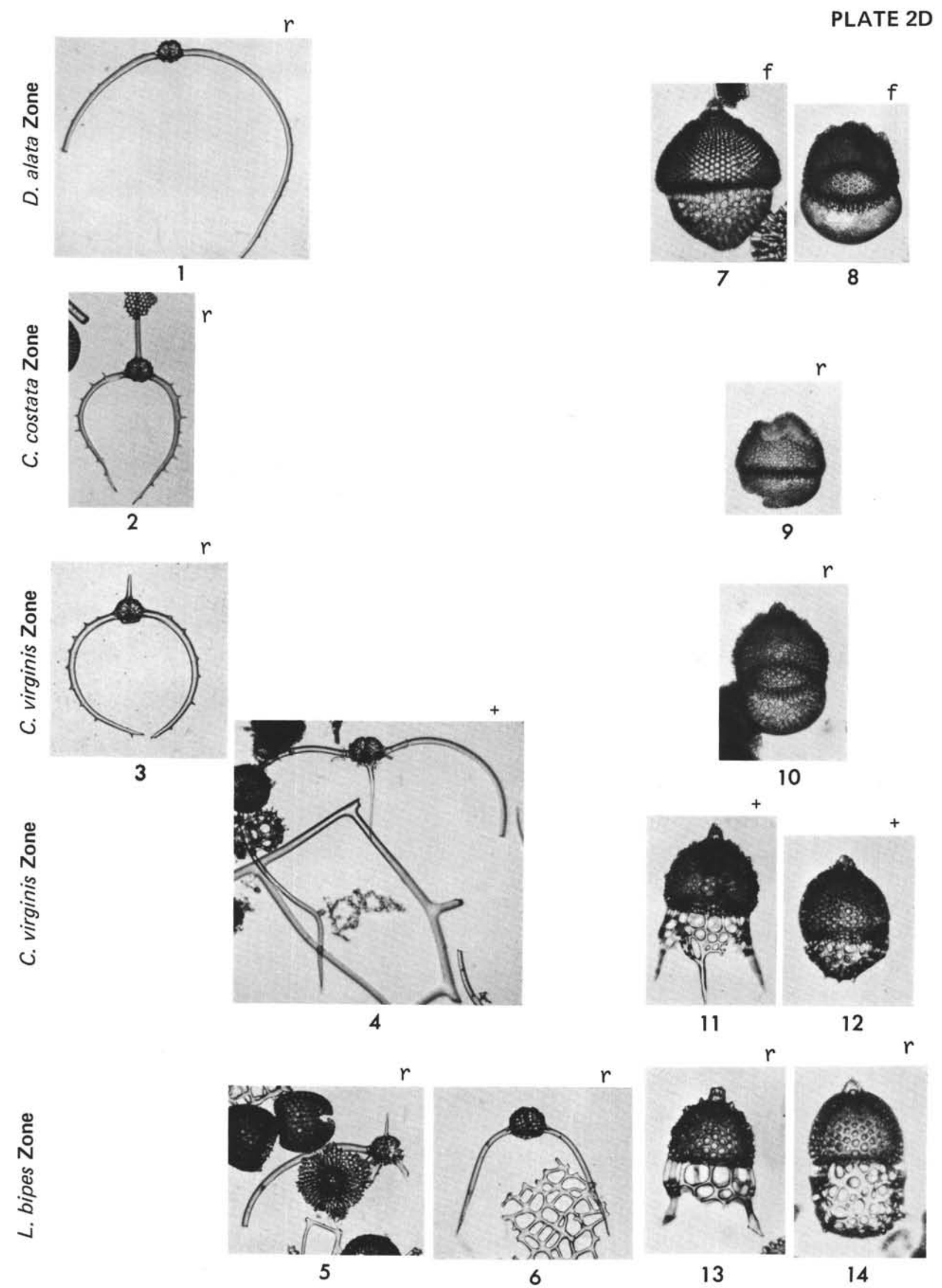


\section{PLATE 2E}

(Magnification 150X)

Figures 1-4 Cyrtocapsella cornuta Haeckel
1: $\mathrm{Ph} .1, \mathrm{P} 32 / 3$.
2: $\mathrm{Sl} 1, \mathrm{~N} 21 / 0$.
3: $\mathrm{Ph} .1, \mathrm{H} 33 / 0$.
4: $\mathrm{Sl} 1, \mathrm{~N} 30 / 0$.

Figures 5-7 Cyrtocapsella tetrapera Haeckel

5: $\mathrm{Ph} .1, \mathrm{~V} 41 / 2$.

6: Ph. $1, \mathrm{~W} 14 / 0$.

7: S1. $1, \mathrm{~S} 26 / 0$.

Figures 8,9 Stichocorys wolffii Haeckel

8: $\mathrm{Ph} .1, \mathrm{~T} 37 / 4$.

9: Ph. 1, V38/0.

Figures 10,11 Stichocorys delmontensis (Campbell and Clark)

10: Ph. 1, X21/0.

11: Ph. $1, \mathrm{~T} 38 / 1$.

Figure 12 Cyrtocapsella japonica (Nakaseko)

Ph. 1, Y5/3.

Figures 13-15 Stichocorys armata (Haeckel)

13: $\mathrm{Ph} .1, \mathrm{~W} 27 / 3$.

14: Sl. $1, \mathrm{~S} 31 / 4$.

15: Ph. $1, \mathrm{~S} 38 / 4$.

Figure $16 \quad$ Stichocorys diploconus (Haeckel) Sl. 1, E14/0.

Figures 17, 18 Lithopera renzae Sanfilippo and Riedel

17: Sl. $1,029 / 0$.

18: Ph. 1, V36/0.

Figure $19 \quad$ Lithopera neotera Sanfilippo and Riedel Ph. 1, M25/1. 
PLATE 2E
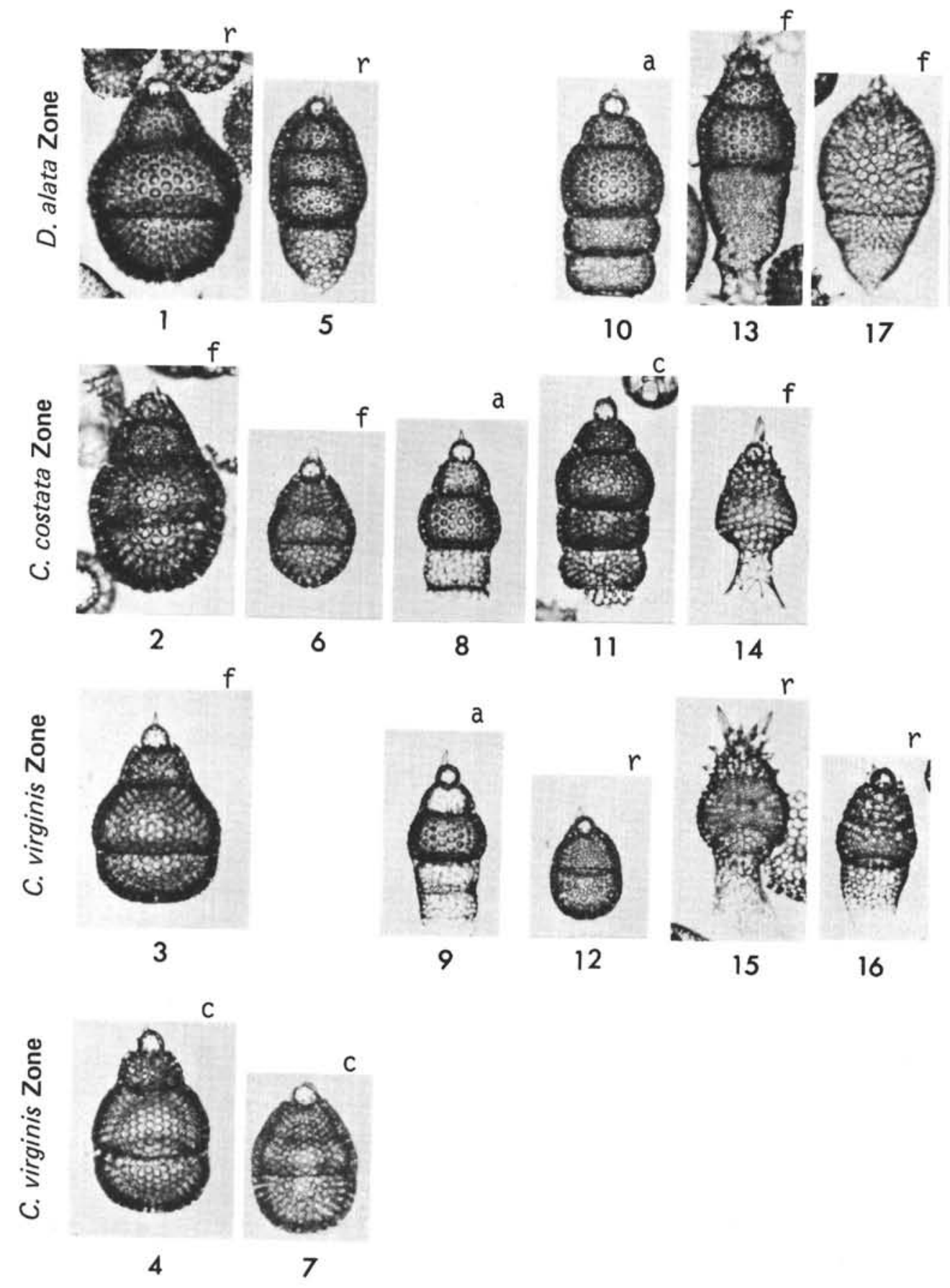

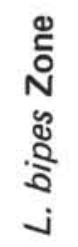




\section{PLATE 2F}

Figures 1,2 Lychnocanium bipes Riedel

1: Cse. 1, E25/3 (95X).

2: Ph. 1, V29/0 (95X).

Figure $3 \quad$ Theocorys sp. (?)

Sl. 1, E32/2 (80X).

Figure $4 \quad$ Theocorys spongoconum Kling Sl. 1, T40/2 (150X).

Figures 5-16 Carpocanistrum spp.

5: Sl. $1, \mathrm{M} 36 / 4$ (150X).

6: Sl. 1, T26/0 (150X).

7: Sl. 1, D35/0 (150X).

8: Sl. 1, M40/1 (150X).

9: Sl. 1, W37/2 (150X).

10: Ph. 1, W18/2 (150X).

11: Sl. $1, \mathrm{X} 20 / 2(150 \mathrm{X})$.

12: Sl. $1, \mathrm{P} 33 / 3(150 \mathrm{X})$.

13: Sl. 1, Q37/2 (150X).

14: Sl. $1, \mathrm{~V} 43 / 3$ (150X).

15: Sl. $1, \mathrm{~K} 32 / 0$ (150X).

16: Sl. 1, D17/0 (150X). 
PLATE 2F

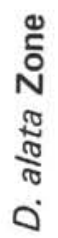

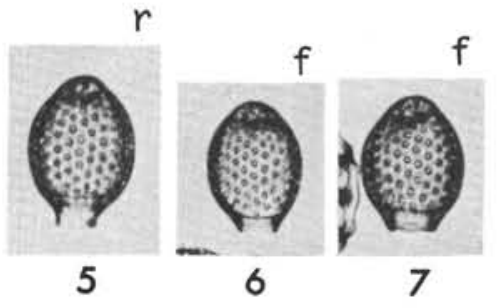

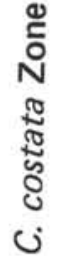

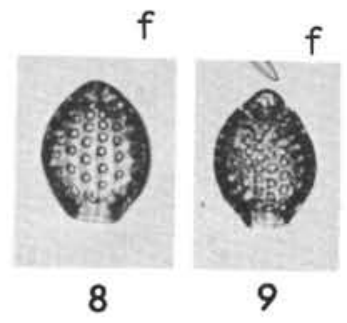

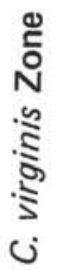
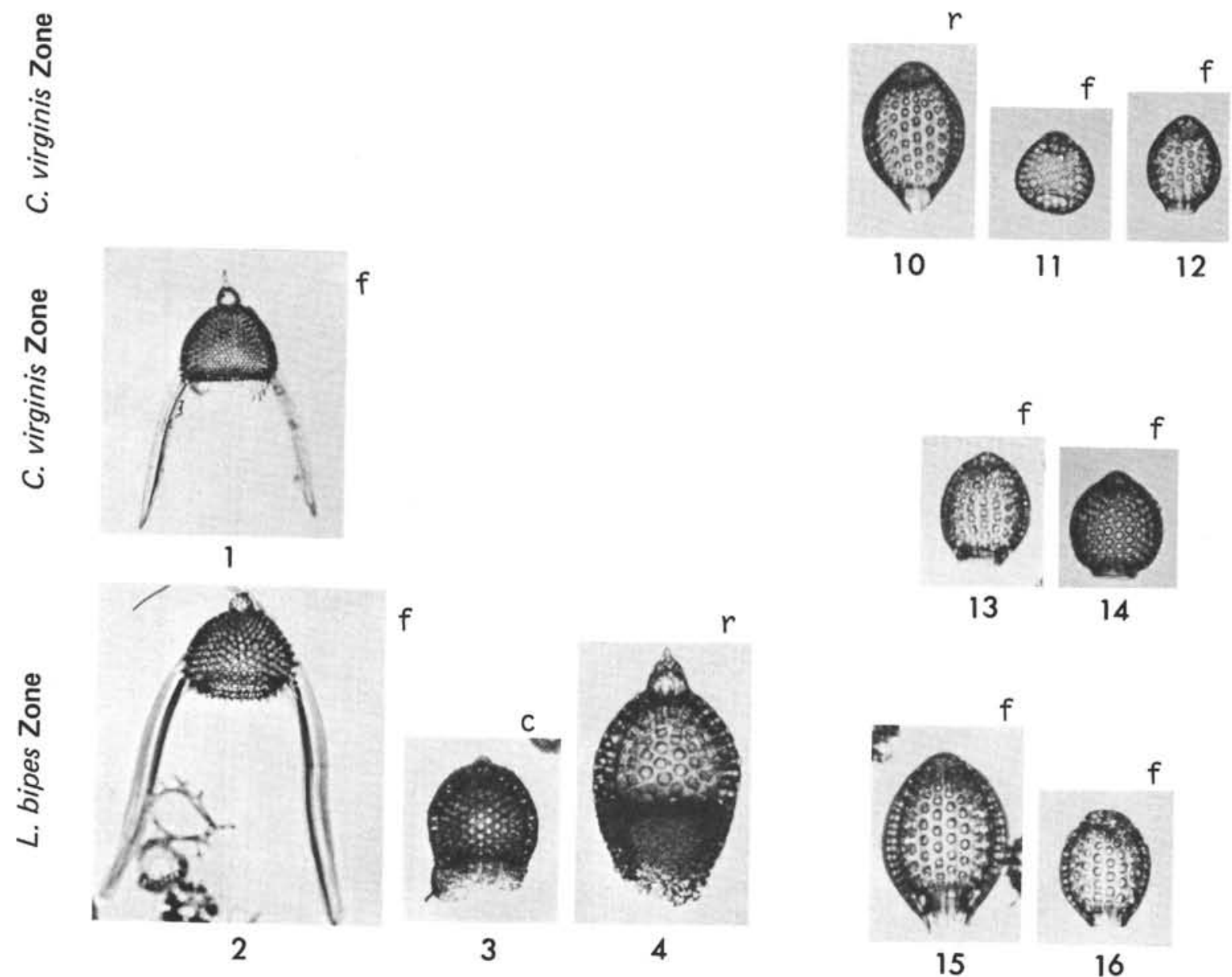


\section{PLATE $2 \mathrm{G}$}

(Magnification 150X)

Figures 1-7 Carpocanopsis cristatum (Carnevale) (?)

1: Sl. $1, \mathrm{~T} 39 / 0$.

2: $66.1-7-3,70-72 \mathrm{~cm}, \mathrm{Sl} .1, \mathrm{~V} 14 / 4$.

3: Sl. $1, \mathrm{~J} 36 / 0$.

4: Sl. $1, \mathrm{R} 25 / 0$.

5: Sl. $1, \mathrm{~S} 41 / 0$.

6: Sl. $1, \mathrm{~K} 49 / 0$.

7: Sl. $1, \mathrm{~N} 24 / 3$.

Figures 8-14 Carpocanopsis bramlettei Riedel and Sanfilippo, n. sp. 8: S1. $1, \mathrm{~V} 21 / 4$.

9: $66.1-7-3,70-72 \mathrm{~cm}, \mathrm{Sl} .1, \mathrm{~L} 14 / 1$.

10: Sl. $1, \mathrm{~L} 35 / 3$.

11: Sl. $1, \mathrm{~N} 25 / 0$.

12: Ph. $1, \mathrm{D} 27 / 0$.

13: Sl. 1, B49/4.

14: Sl. $1, \mathrm{~K} 37 / 1$.

Figures 15,16 Carpocanopsis favosum (Haeckel)

15: Sl. 1, W30/2.

16: Sl. $1, \mathrm{Y} 19 / 0$.

Figures 17-21 Carpocanopsis cingulatum Riedel and Sanfilippo, n. sp.

17: Sl. 1, R18/2.

18: Sl. $1, \mathrm{~T} 16 / 0$.

19: Sl. $1, \mathrm{~K} 46 / 1$.

20: Sl. $1, \mathrm{~L} 43 / 1$.

21: Sl. $1, \mathrm{M} 49 / 0$. 
PLATE 2G
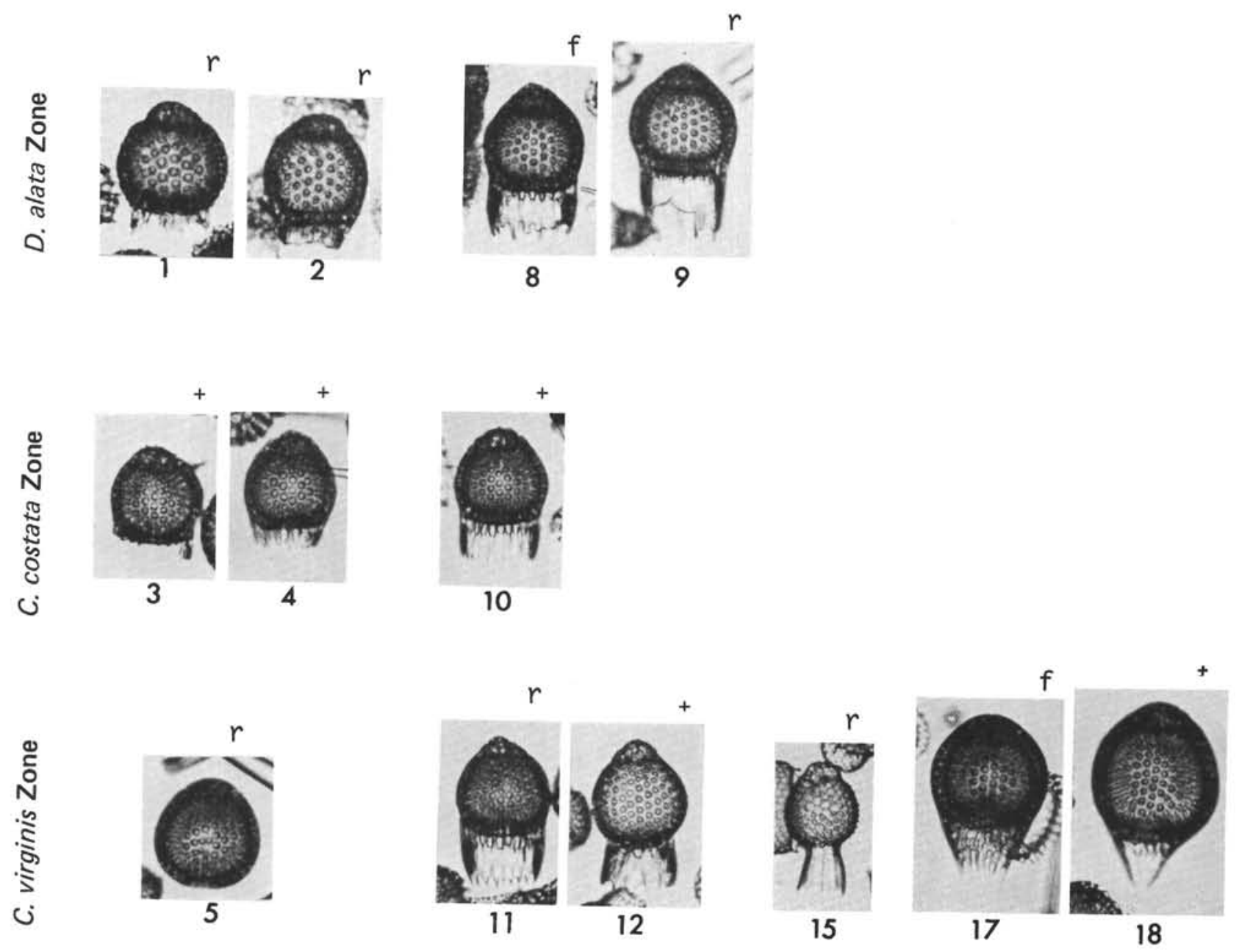

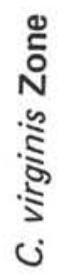
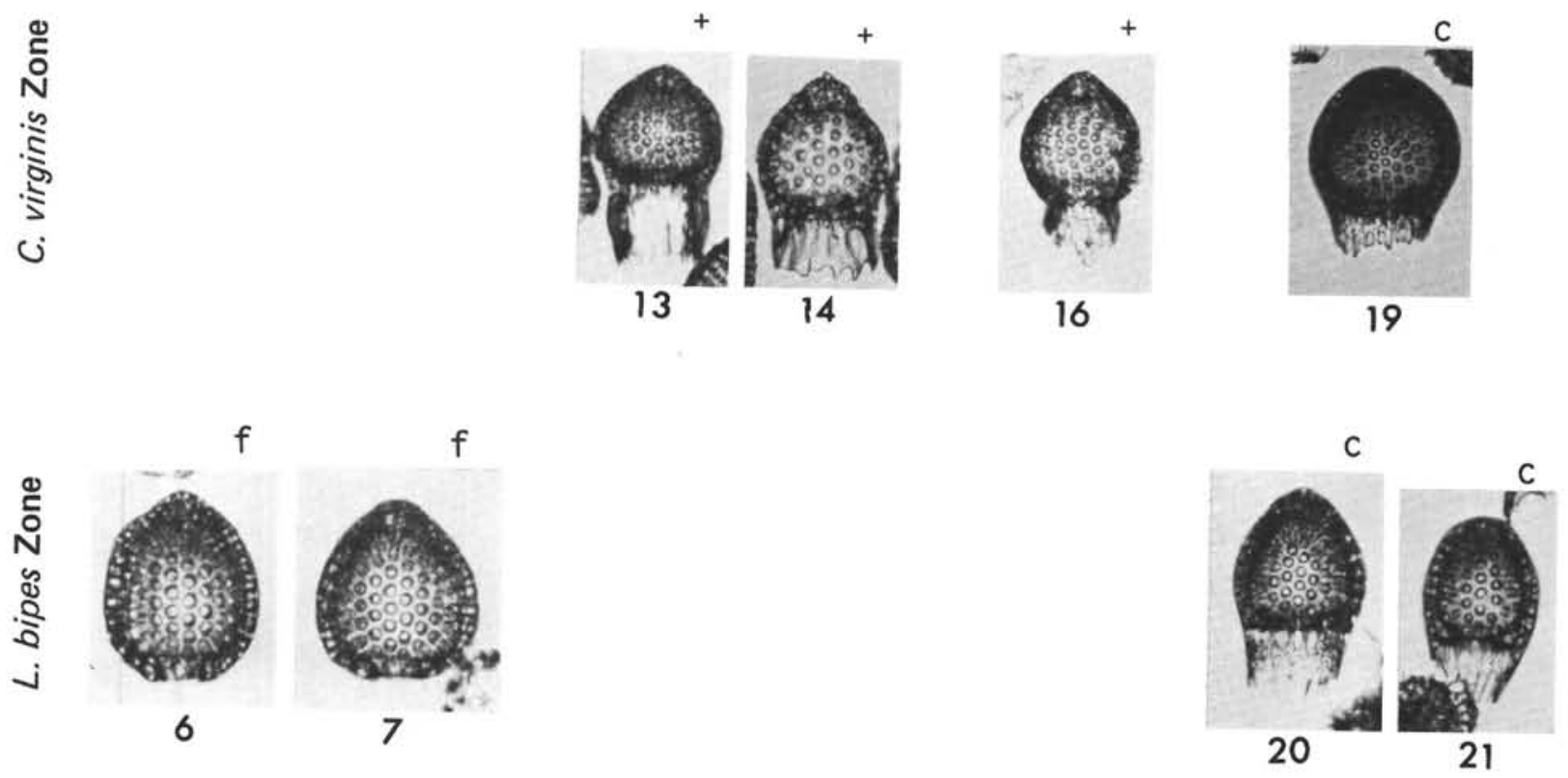


\section{PLATE 2H}

Figures 1-3 Calocycletta sp.

1: Ph. 1, K19/2 (95X).

2: Ph. 1, P20/4 (95X).

3: S1. 1, P33/0 (95X).

Figure $4 \quad$ Theocyrtis annosa (Riedel) Ph. 1, R16/2 (95X).

Figures 5-11 Calocycletta virginis Haeckel

5: Ph. 1, D51/2 (95X).

6: Ph. 1, G45/0 (95X).

7: Ph. 1, F21/0 (95X).

8: Ph. 1, Q19/2 (95X).

9: Ph. 1, W34/0 (95X).

10: S1. 1, B24/3 (95X).

11: Ph. 1, N23/3 (95X).

Figures 12-14 Calocycletta costata (Riedel)

12: S1. 1, K39/4 (95X).

13: S1. 1, X29/0 (95X).

14: Ph. 1, J33/2 (95X).

Figures 15-18 Spirocyrtis sp. aff. S. scalaris Haeckel 15: S1. 1, U29/4 (150X).

16: Ph. 1, U34/0 (150X).

17: Sl. $1, \mathrm{X} 42 / 2(150 \mathrm{X})$.

18: S1. 1, L51/2 (150X). 

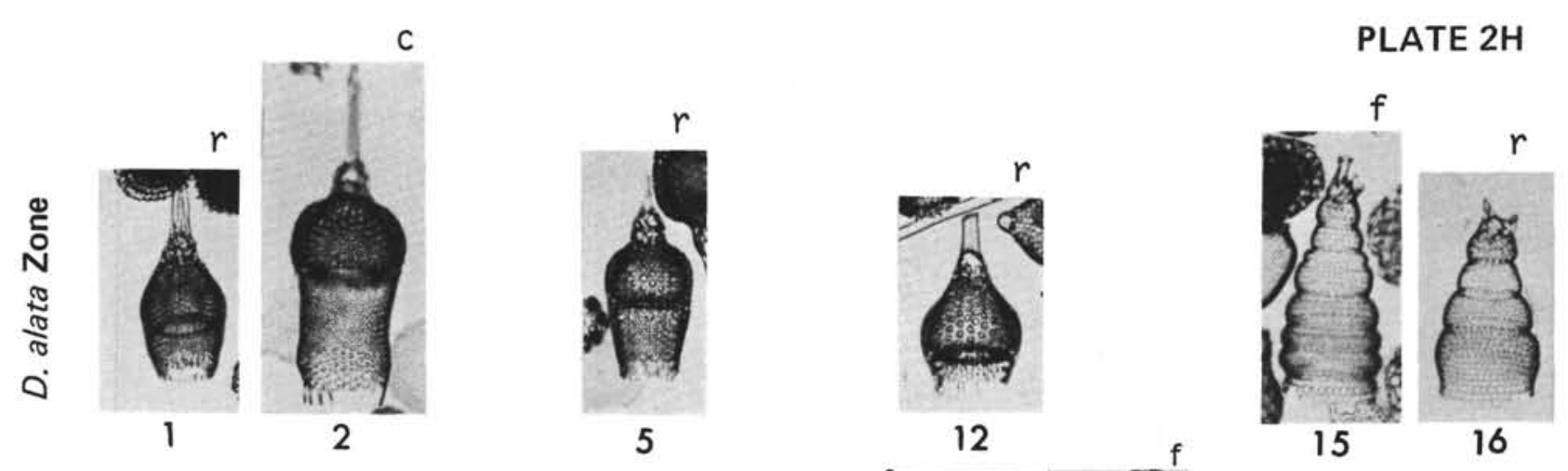

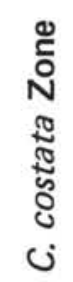
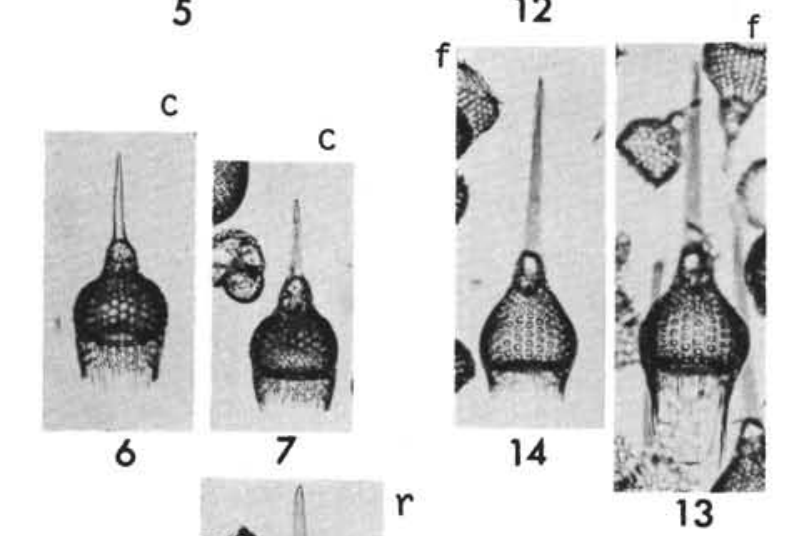

15
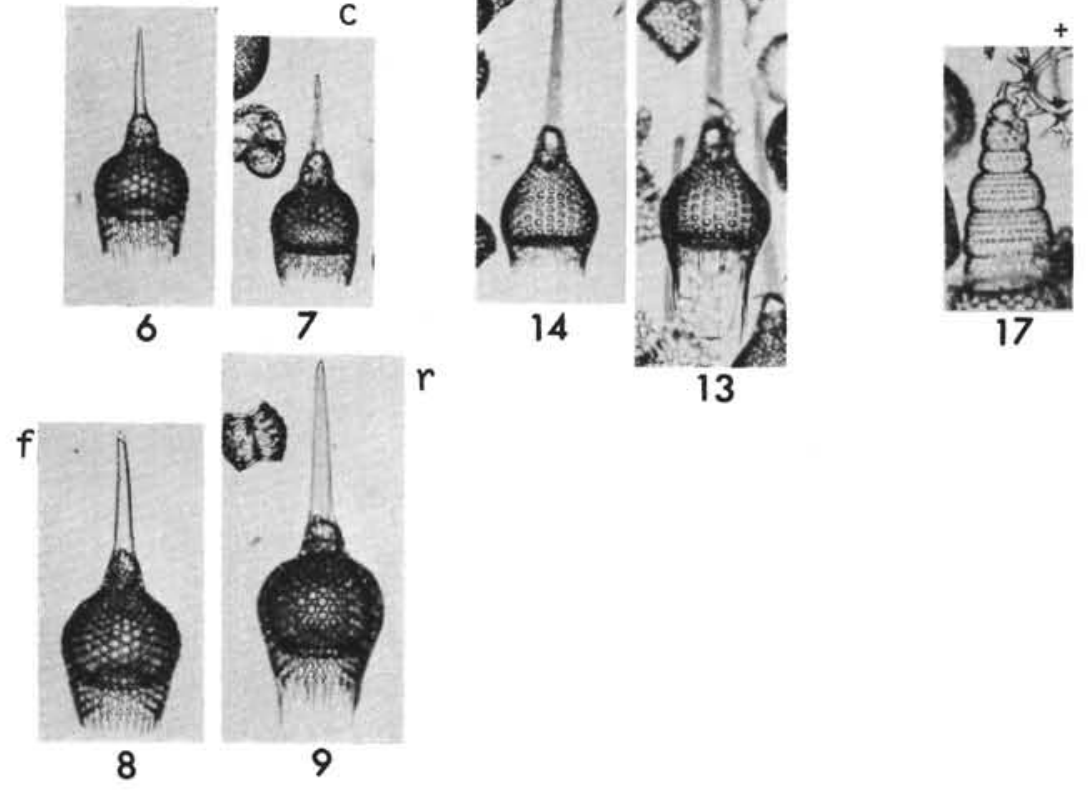

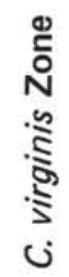
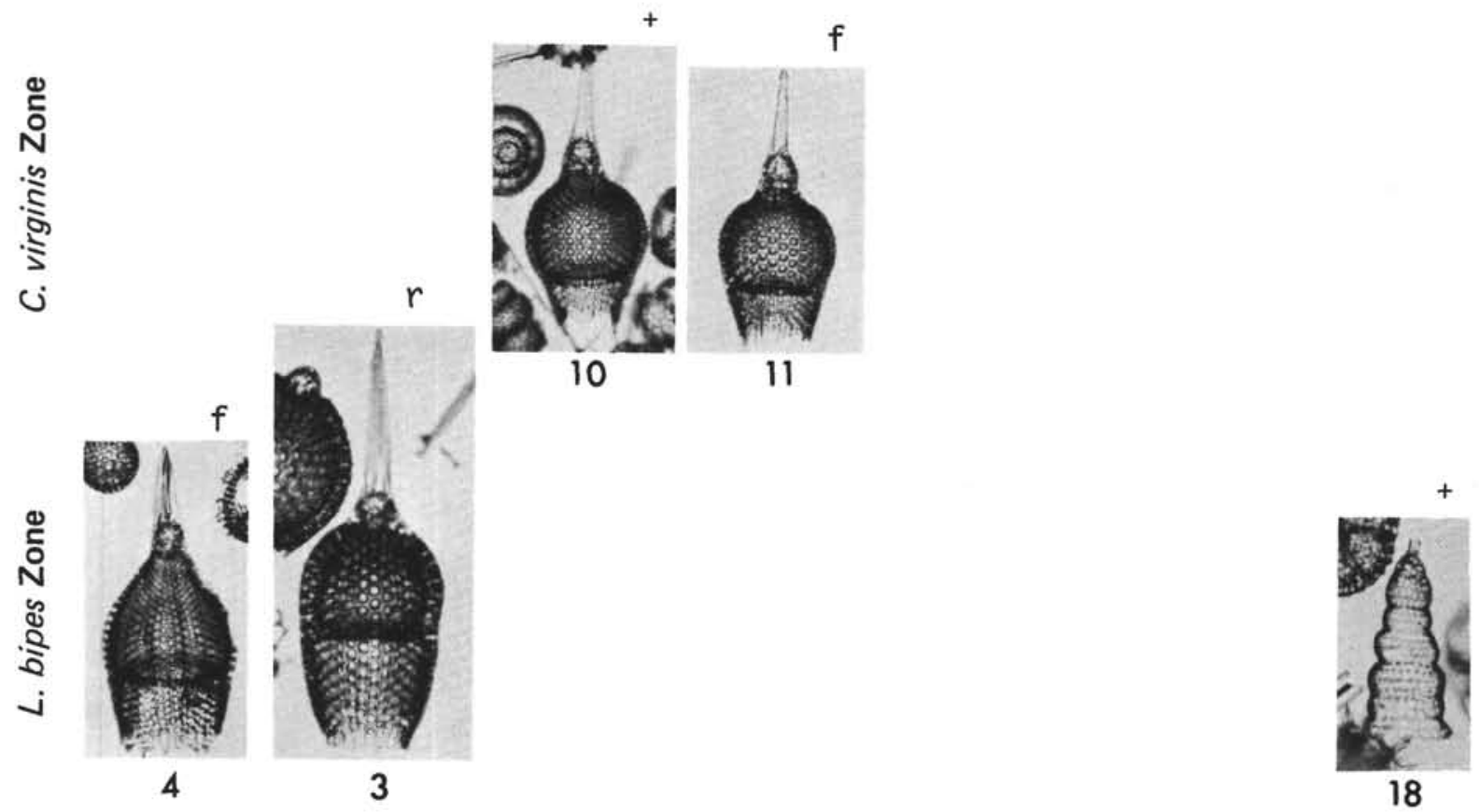
PLATE 2I

(Magnification 150X)

Figures 1-8 Artostrobium sp. aff. A. doliolum Riedel and Sanfilippo, n. sp.

1: Sl. $1, \mathrm{X} 23 / 0$.

2: Sl. $1,040 / 2$.

3: Ph. $1,028 / 0$.

4: Ph. $1, \mathrm{P} 35 / 4$.

5: $\mathrm{Ph} .1, \mathrm{X} 39 / 0$.

6: S1. $1, \mathrm{D} 21 / 3$.

7: Ph. $1, \mathrm{C} 30 / 2$.

8: Sl. $1, \mathrm{H} 14 / 0$.

Figures 9, 10 Artostrobium miralestense (Campbell and Clark)

9: $\mathrm{Ph} .1, \mathrm{~S} 41 / 1$.

10: Sl. $1,043 / 4$.

Figures 11-13 Siphocampe sp. aff. S. corbula (Harting)

11: Ph. 1, D45/4.

12: Sl. $1, \mathrm{M} 37 / 3$.

13: Sl. $1, \mathrm{~T} 24 / 2$.

Figures 14-16 Lithomitra lineata (Ehrenberg) group

14: Ph. 1, U29/4.

15: Ph. $1, \mathrm{~F} 34 / 2$.

16: Sl. $1, \mathrm{X} 44 / 0$.

Figure 17

Lithomitra sp. aff. L. lineata (Ehrenberg) group Ph. 1, W40/1. 
PLATE 2I
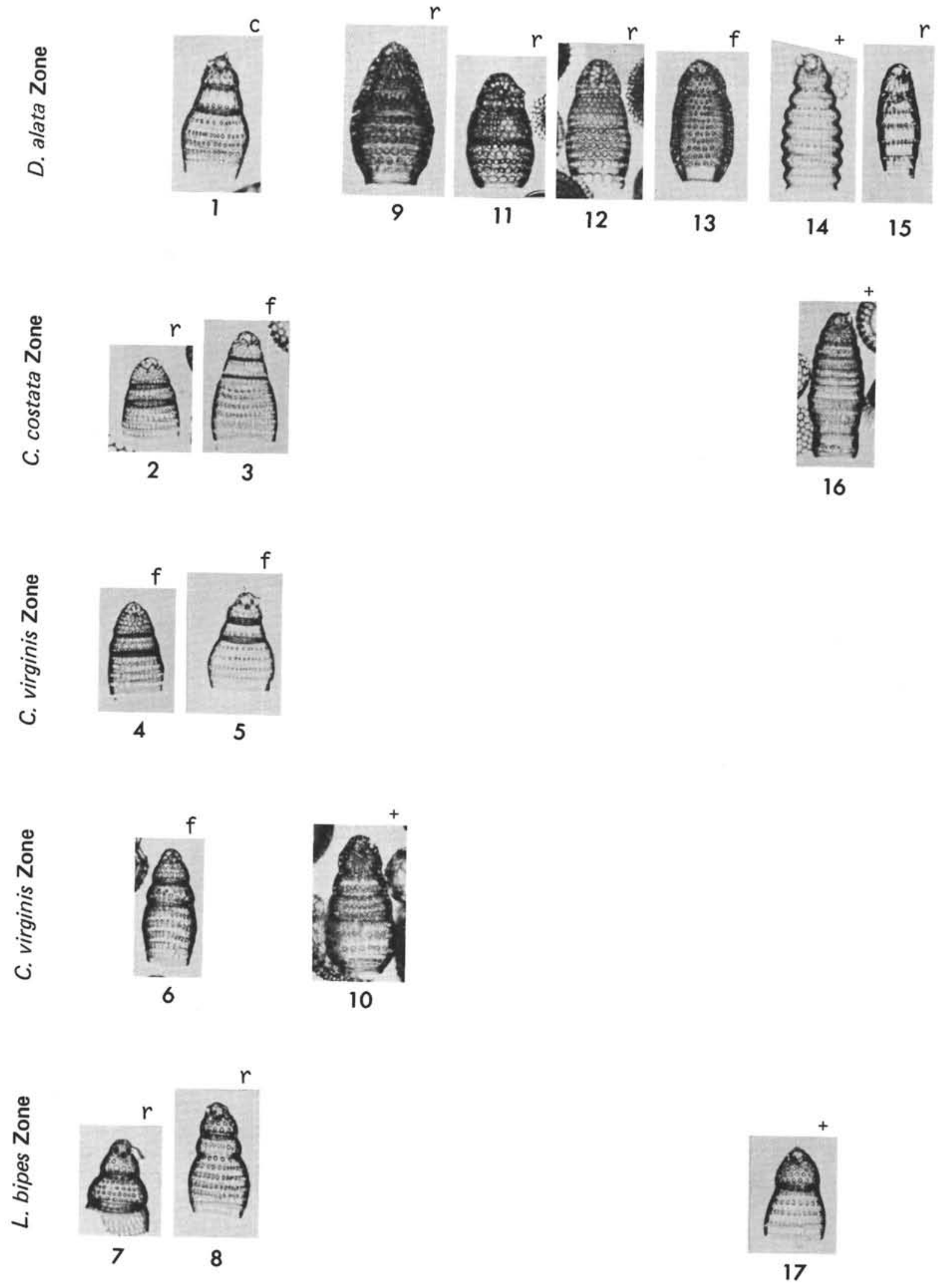


\section{PLATE 2J}

(Magnification 150X)

Figures 1-5 Phormostichoartus corona Haeckel

1: $\mathrm{Ph} .1, \mathrm{~K} 23 / 0$.

2: $\mathrm{Ph} .1, \mathrm{~J} 38 / 4$.

3: Ph. $1, \mathrm{R} 30 / 0$.

4: Sl. $1, \mathrm{X} 11 / 0$.

5: Sl. 1, R29/1.

Figures 6, 7 Phormostichoartus sp. aff. P. corona Haeckel 6: Sl. $1, \mathrm{R} 35 / 0$.

7: S1. $1, \mathrm{G} 35 / 4$.

Figures 8,9 Carpocanarium spp.

8: Sl. $1, \mathrm{X} 24 / 1$.

9: S1. $1, \mathrm{P} 34 / 3$.

Figures 10-12 Botryocyrtis spp. 10: Sl. 1, T41/3.

11: $\mathrm{Sl} .1, \mathrm{~V} 40 / 0$.

12: Sl. $1, \mathrm{R} 15 / 4$.

Figures 13-15 Acrobotrys spp.

13: Sl. 1, R19/0.

14: Sl. $1, \mathrm{P} 18 / 3$.

15: Sl. $1, \mathrm{E} 21 / 4$.

Figures 16-18 Botryopyle dictyocephalus Haeckel group 16: Sl. 1, Q40/3.

17: Ph. $1, \mathrm{H} 39 / 4$.

18: Ph. $1, \mathrm{U} 14 / 1$.

Figure 19 Centrobotrys thermophila Petrushevskaya 19: Sl. 1, S24/2.

Figures 20, $21 \quad$ Botryopyle sp. A

20: Sl. 1, D41/1.

21: Ph. 1, W17/0. 
PLATE 2J
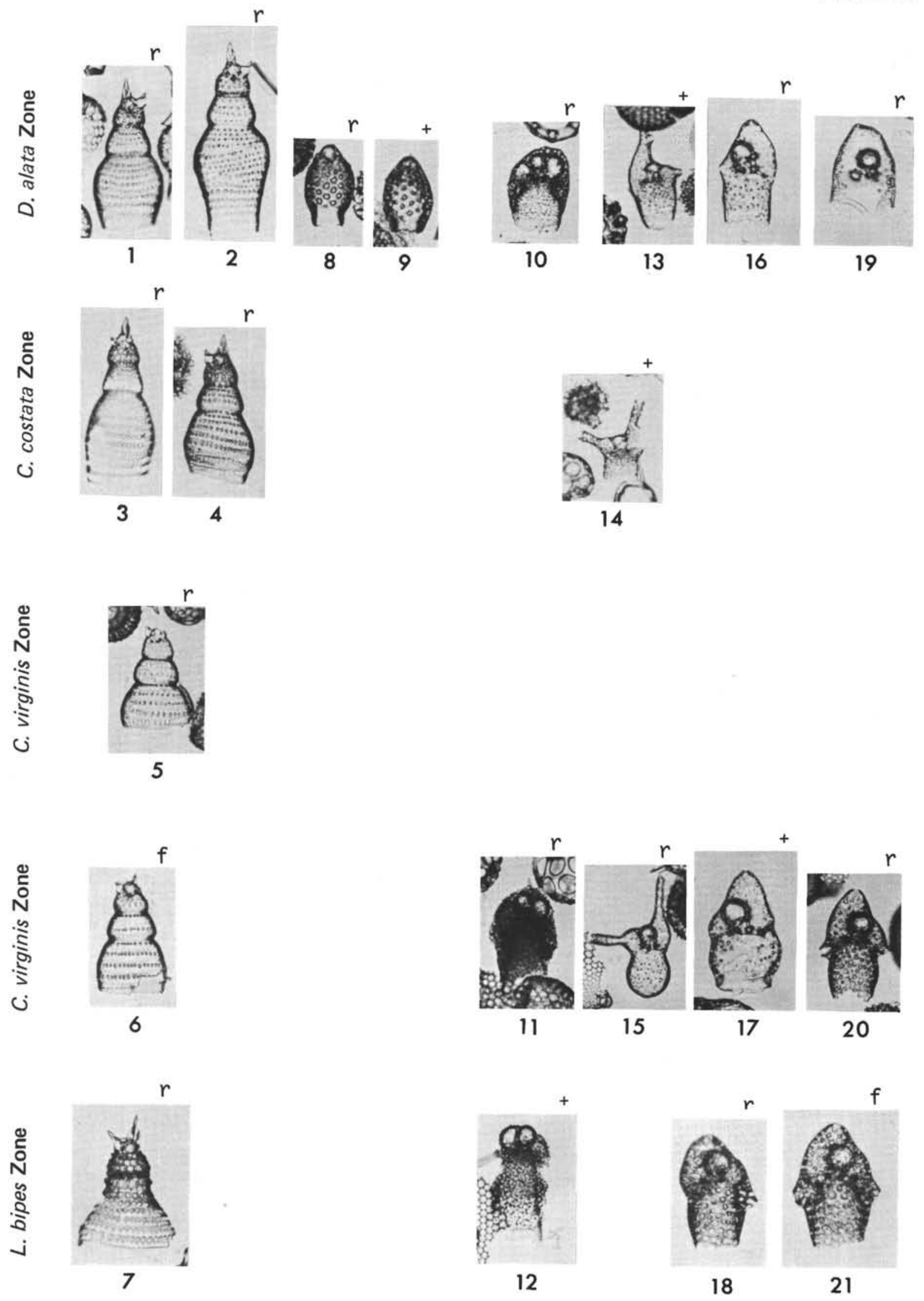
PLATE 3A

Figures 1, $3 \quad$ Lithocyclia angustum (Riedel)

1: Sl. $1, \mathrm{Y} 41 / 2(150 \mathrm{X})$.

3: Sl. 1, Q41/1 (150X).

Figure 2 Lithocyclia sp. cf. L. angustum (Riedel) Sl. 1, K36/0 (150X).

Figures 4, $5 \quad$ Lithocyclia aristotelis (Ehrenberg) group 4: Cse. 1, Y37/1 (150X).

5: Cse. $1, \mathrm{~W} 26 / 3$ (150X).

Figure $6 \quad$ Lithocyclia ocellus Ehrenberg group Sl. 1, T49/4 (150X).

Figure 7 Dorcadospyris papilio (Riedel) Cse. 1, N18/1 (60X).

Figure $8 \quad$ Dorcadospyris forcipata (Haeckel) Cse. 1, N22/0 (60X).

Figures 9, 10 Dorcadospyris ateuchus (Ehrenberg)

9: Cse. 1, N18/4 (60X).

10: Cse. 1, F20/1 (60X).

Figures 11, 12 Tristylospyris triceros (Ehrenberg)

11: Cse. 1, J24/3 (60X).

12: Cse. 1, U26/4 (60X). 
PLATE 3A

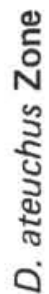
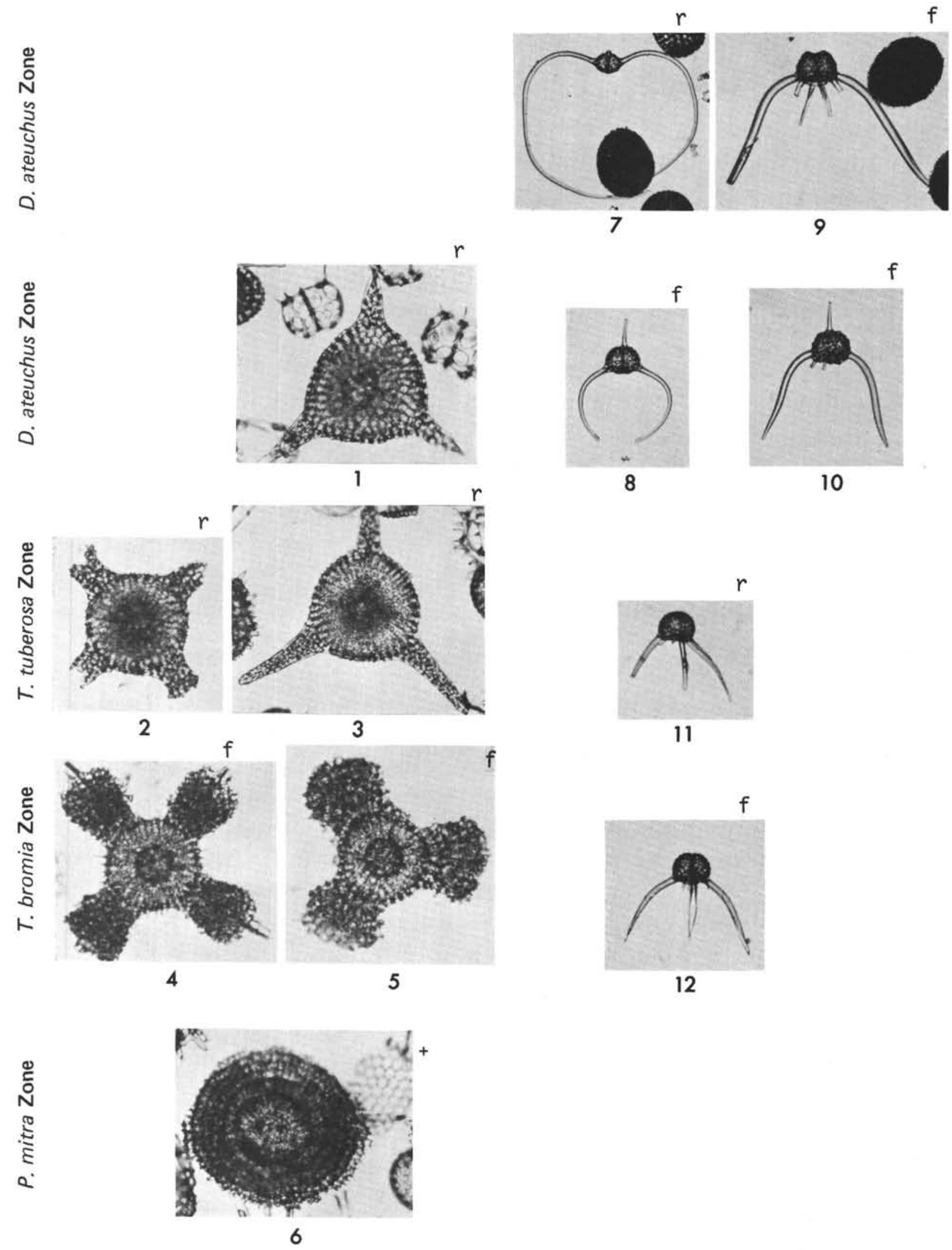


\section{PLATE 3B}

Figures 1,2 Cyclampterium (?) pegetrum Sanfilippo and Riedel 1: 64.1-8-CC, Cse. 1, D27/4 (80X).

2: 64.1-8-CC, Cse. 1, M24/0 (80X).

Figure $3 \quad$ Cyclampterium (?) milowi Riedel and Sanfilippo, $\mathrm{n}$. sp. 64.0-10-1, Top, Cse. 1, Y19/0 (80X).

Figure $4 \quad$ Calocycloma (?) ampulla (Ehrenberg)

Cse. 1, L32/0 (95X).

Figures 5-7 Artophormis gracilis Riedel

5: Ph. 1, Y24/1 (150X).

6: Ph. $1,029 / 4(150 X)$.

7: Ph. 1, K34/1 (150X).

Figures 8,9 Artophormis barbadensis (Ehrenberg)

8: S1. 1, D24/0 (150X).

9: Cse. 1, R35/0 (150X).

Figures 10,11 Cycladophora hispida (Ehrenberg)

10: Sl. 1, X39/4 (95X).

11: Sl. 1, R25/4 (95X).

Figure 12 Lychnocanium trifolium Riedel and Sanfilippo, n. sp. Sl. 1, T31/0 (150X).

Figure $13 \quad$ Sethochytris babylonis (Clark and Campbell) group Sl. 1, M42/2 (150X).

Figure $14 \quad$ Eusyringium fistuligerum (Ehrenberg)

Sl. 1, V40/2 (95X). 
PLATE 3B

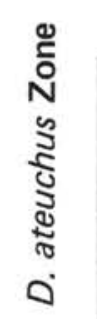

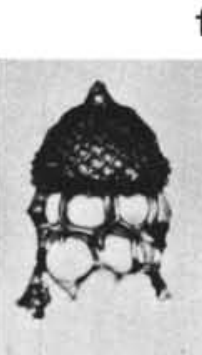

1

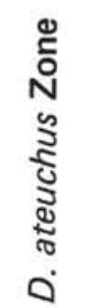
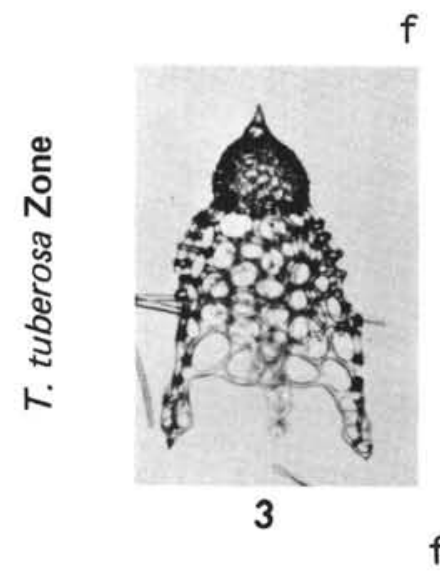

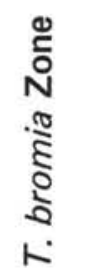

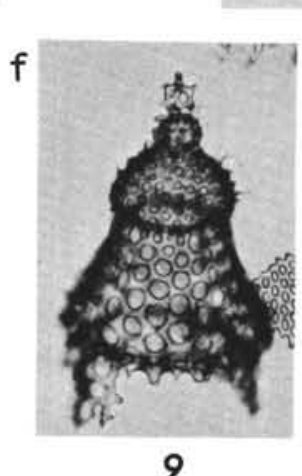

$$
9
$$
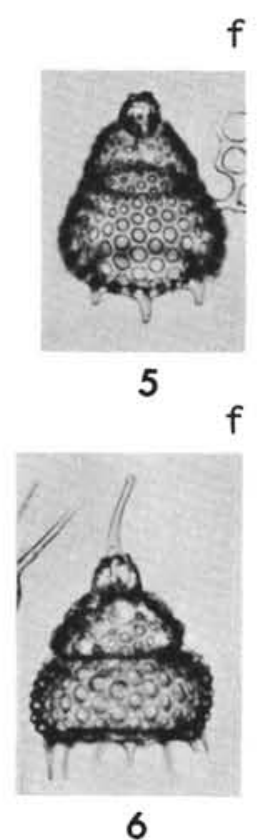

6

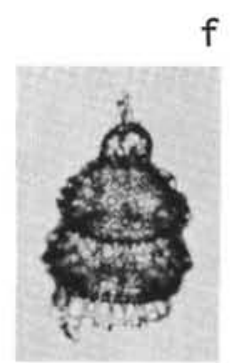

7

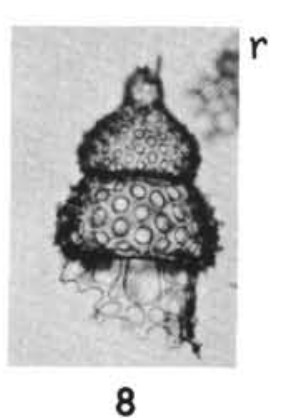

\footnotetext{
$-$
}

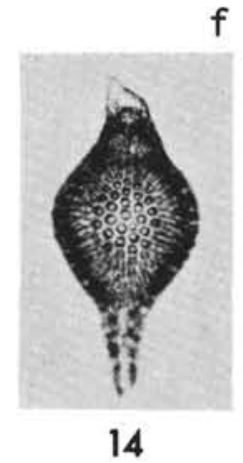

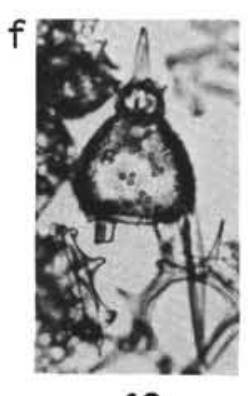

12
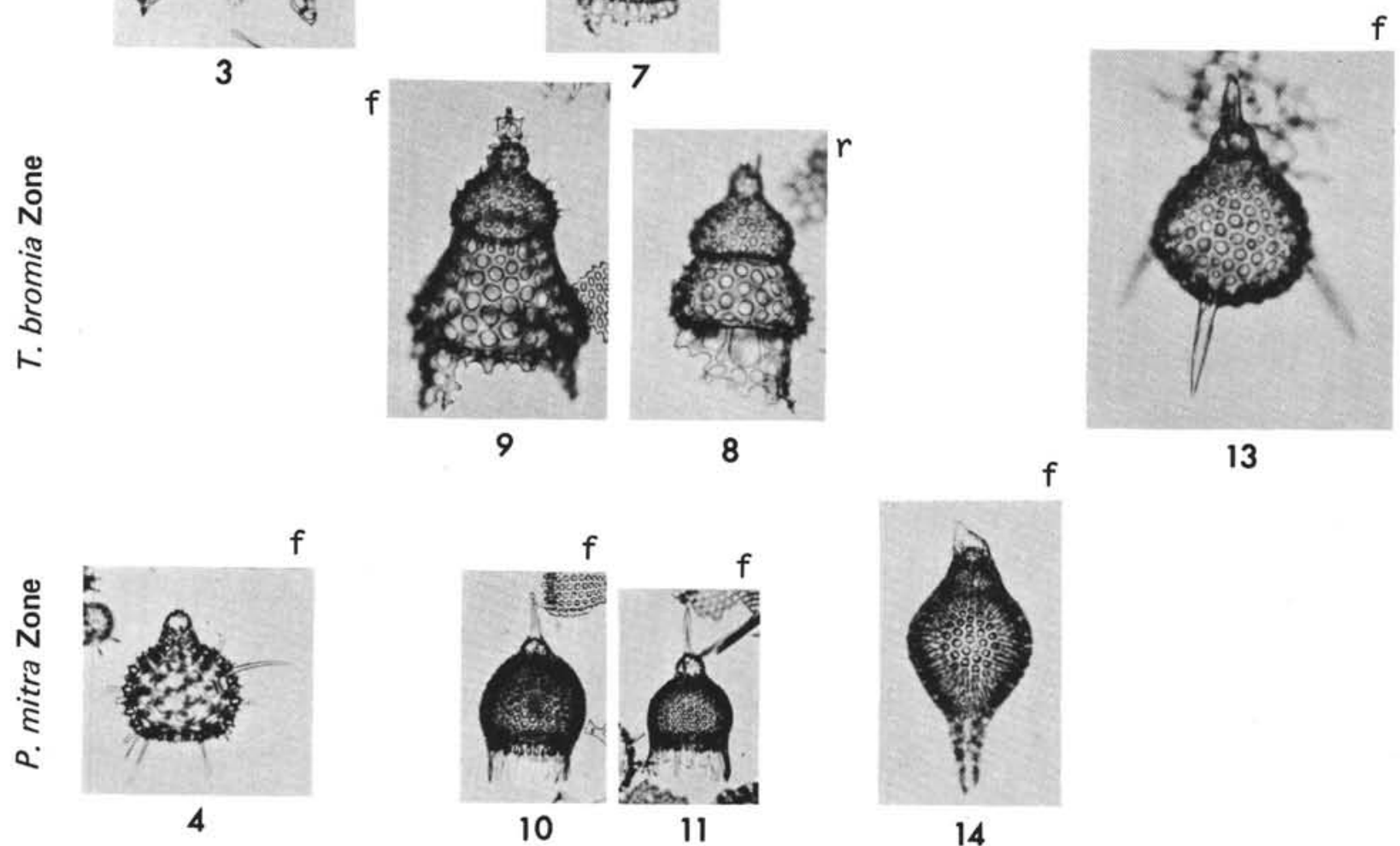

13 
PLATE 3C

Figures 1, $2 \quad$ Lychnocanium sp. aff. L. bellum Clark and Campbell

1: Ph. 1, L46/1 (95X).

2: Ph. 1, T48/0 (95X).

Figure $3 \quad$ Theocorys spongoconum Kling Ph. 1, N41/1 (150X).

Figures 4, $5 \quad$ Lophocyrtis (?) jacchia (Ehrenberg)

4: Ph. 1, T10/3 (95X)

5: Ph. $1,039 / 2(95 X)$

Figure 6

Thyrsocyrtis rhizodon Ehrenberg

Cse. 1, L32/0 (95X).

Figure $7 \quad$ Thyrsocyrtis triacantha (Ehrenberg) Ph. 1, E52/0 (95X). 


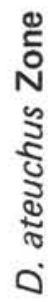

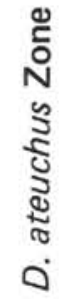

ํํำ

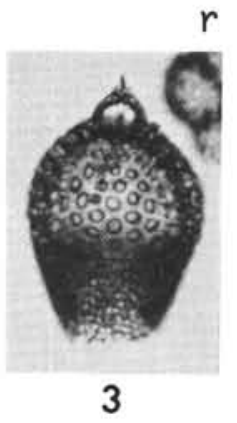

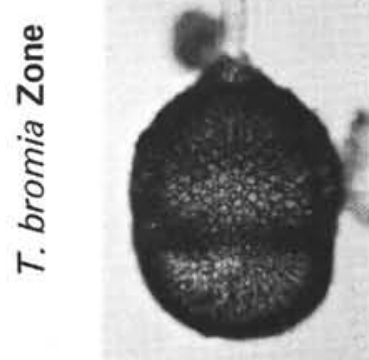

1
C

$r$

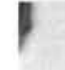

ัํำ

ह

Q
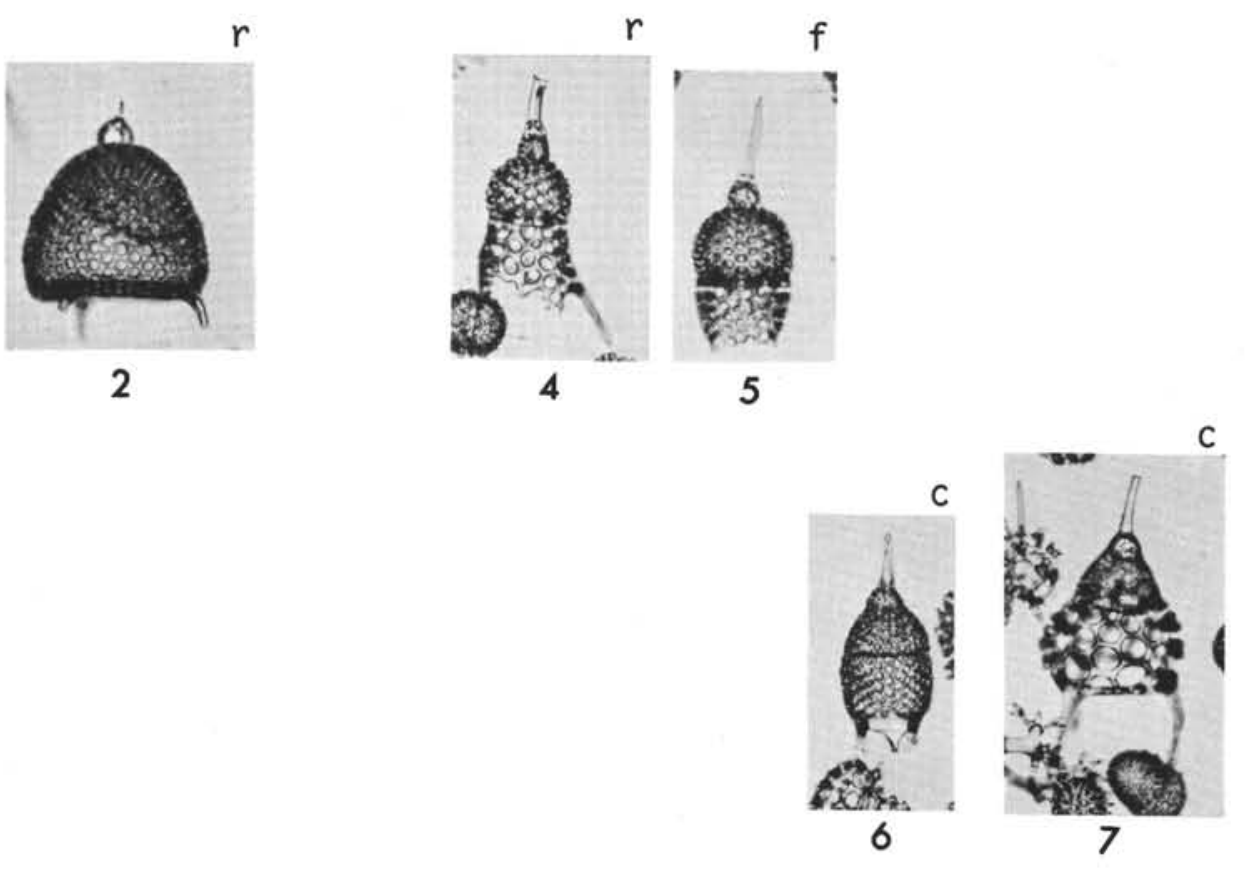
PLATE 3D

Figures 1, 2, Carpocanistrum spp.

3-5 (?), 6, 7, 1: Ph. 1, K51/4 (150X).

$8(?), 9$

2: Ph. 1, J44/3 (150X).

3: Ph. 1, Q46/2 (150X).

4: Sl. $1, \mathrm{~N} 50 / 2(150 \mathrm{X})$.

5: Sl. 1, J36/4 (150X).

6: Sl. 1, F28/4 (150X).

7: Sl. $1, \mathrm{G} 30 / 0$ (150X).

8: Sl. $1,048 / 2(150 X)$.

9: $\mathrm{Sl} .1, \mathrm{R} 52 / 3(150 \mathrm{X})$.

Figures 10,11 Cryptoprora ornata Ehrenberg

10: Sl. 1, T34/0 (150X).

11: Sl. 1, D16/1 (150X).

Figures 12, 13 Theocyrtis annosa (Riedel)

12: Si. $1, \mathrm{Y} 42 / 0(95 \mathrm{X})$.

13: Sl. 1, M20/2 (95X).

Figures 14, 15 Theocyrtis tuberosa Riedel

14: Sl. 1, U43/0 (95X).

15: Ph. 1, C52/4 (95X).

Figures 16-18 Theocyrtis sp. aff. T. tuberosa Riedel

16: Sl. 1, Q20/0 (95X).

17: Sl. $1, \mathrm{~K} 41 / 0(95 \mathrm{X})$.

18: Sl. 1, V19/0 (95X).

Figure 19 Podocyrtis mitra Ehrenberg 

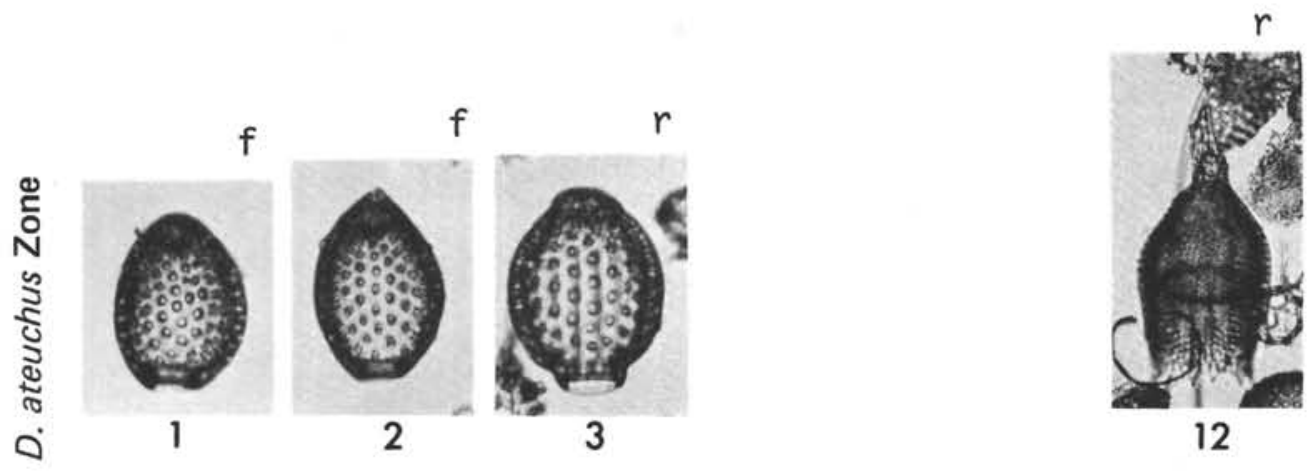

PLATE 3D
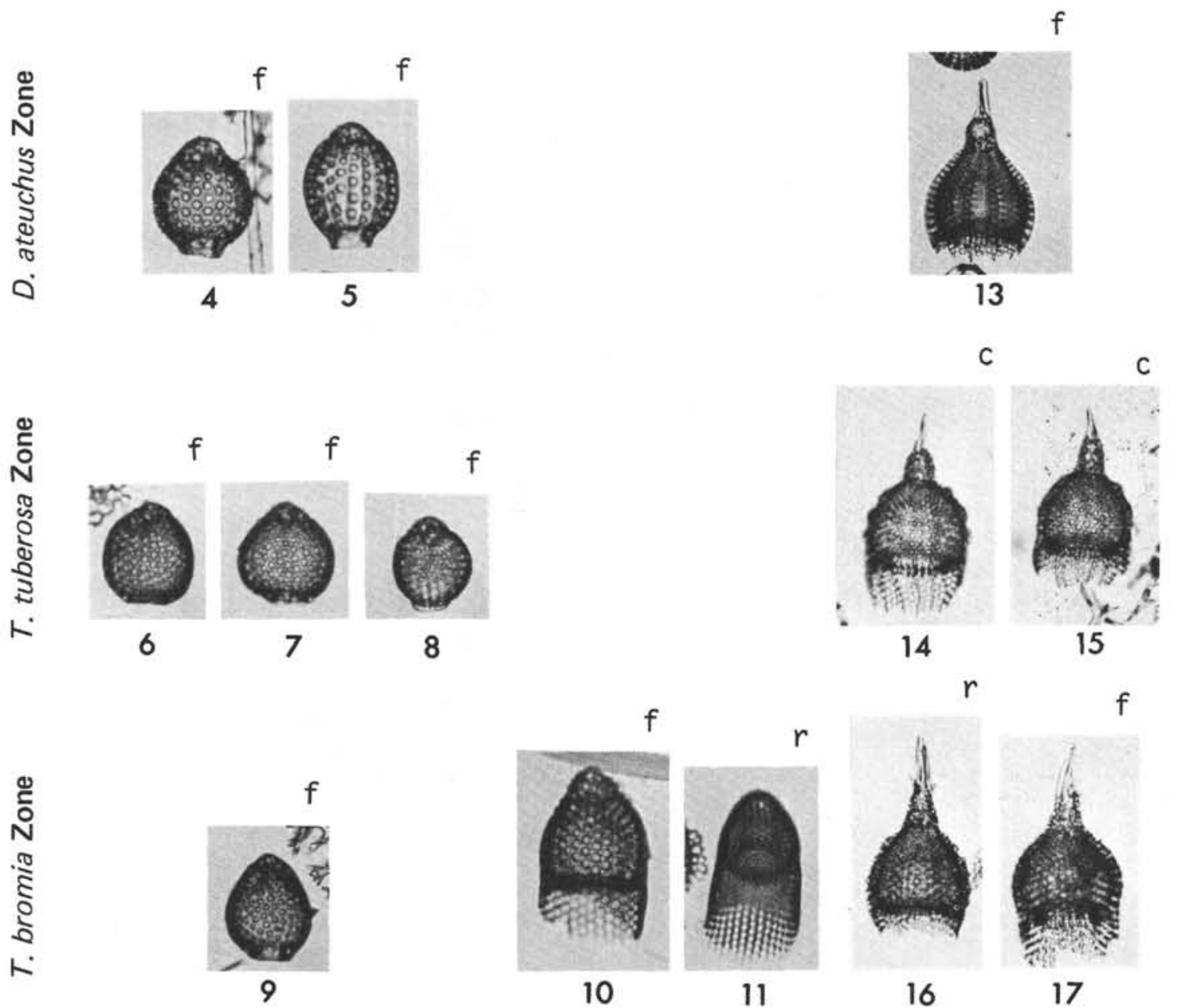

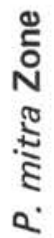
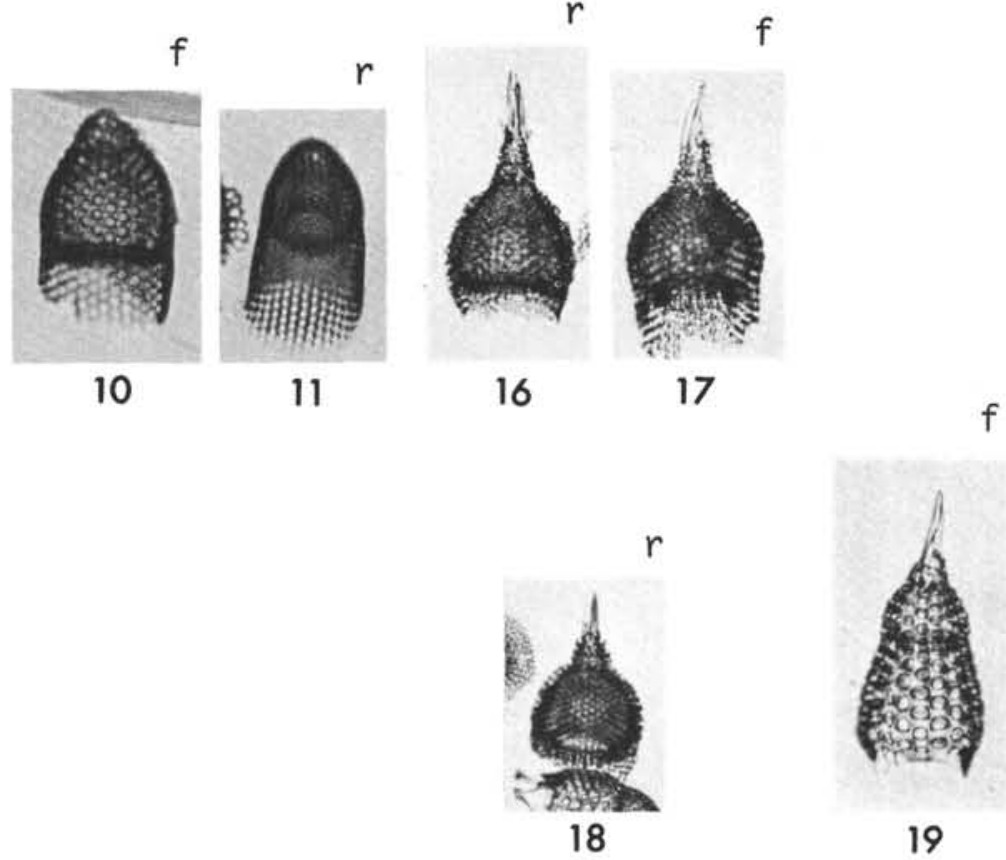
PLATE 3E

Figure $1 \quad$ Podocyrtis papalis Ehrenberg

Sl. 1, X21/1 (95X).

Figure 2 Spirocyrtis sp. aff. S. scalaris Haeckel Sl. 1, U46/0 (150X).

Figures 3-6 Theocampe armadillo (Ehrenberg) group

3: Ph. 1, R44/4 (150X).

4: Sl. $1, \mathrm{~B} 22 / 3(150 \mathrm{X})$.

5: Sl. $1, \mathrm{~N} 48 / 4(150 \mathrm{X})$.

6: Ph. 1, Q29/1 (150X).

Figures 7-9 Artostrobium sp. aff. A. doliolum Riedel and Sanfilippo, n. sp.

7: Sl. 2, V18/4 (150X).

8: Sl. 2, B28/0 (150X).

9: Sl. 1, U46/0 (150X).

Figures 10,11 Theocampe pirum (Ehrenberg)

10: Sl. 1, M37/1 (150X).

11: Ph. 1, Y26/4 (150X).

Figure 12 Artostrobium miralestense (Campbell and Clark) Ph. 1, J30/1 (150X).

Figure 13 Theocampe mongolfieri (Ehrenberg)

Ph. 1, Y49/3 (150X).

Figure $14 \quad$ Lithomitra lineata (Ehrenberg) group Sl. 1, G32/3 (150X).

Figures 15-19 Lithomitra sp. aff. L. lineata (Ehrenberg) group 15: Sl. 1, H18/4 (150X).

16: Sl. 1, R22/0 (150X).

17: Sl. 1, Y29/0 (150X).

18: Sl. $1, \mathrm{~W} 43 / 0(150 \mathrm{X})$.

19: Sl. $1, \mathrm{~W} 43 / 0(150 \times)$. 


$$
\begin{aligned}
& 1 \\
& 10^{1} \\
& 1010 \\
& 10000000
\end{aligned}
$$


PLATE 3F

(Magnification 150X)

Figures 1-6 Phormostichoartus sp. aff. P. corona Haeckel

1: Ph. $1, \mathrm{~S} 35 / 2$.

2: Ph. 1, U41/1.

3: Sl. $1, \mathrm{E} 18 / 4$.

4: Sl. $1, \mathrm{~J} 41 / 4$.

5: Sl. $1, \mathrm{~B} 47 / 4$.

6: Sl. 1, L36/3.

Figure 7 Botryocyrtis sp.

Ph. 1, R43/4.

Figure $8 \quad$ Acrobotrys sp.

Sl. 1, G27/3.

Figures 9-12 Botryopyle dictyocephalus Haeckel group 9: Sl. $1, \mathrm{U} 31 / 2$.

10: Ph. $1, \mathrm{~S} 38 / 0$.

11: Ph. $1, \mathrm{~L} 32 / 3$.

12: Ph. 1, U35/4.

Figure $13 \quad$ Botryopyle sp. A

$\mathrm{Ph} .1, \mathrm{C} 16 / 2$.

Figure $14 \quad$ Centrobotrys thermophila Petrushevskaya Ph. 1, Q17/0.

Figures 15, 16 Centrobotrys (?) sp. A

15: Sl. 1, P37/0.

16: Ph. 1, Q35/0. 
PLATE 3F
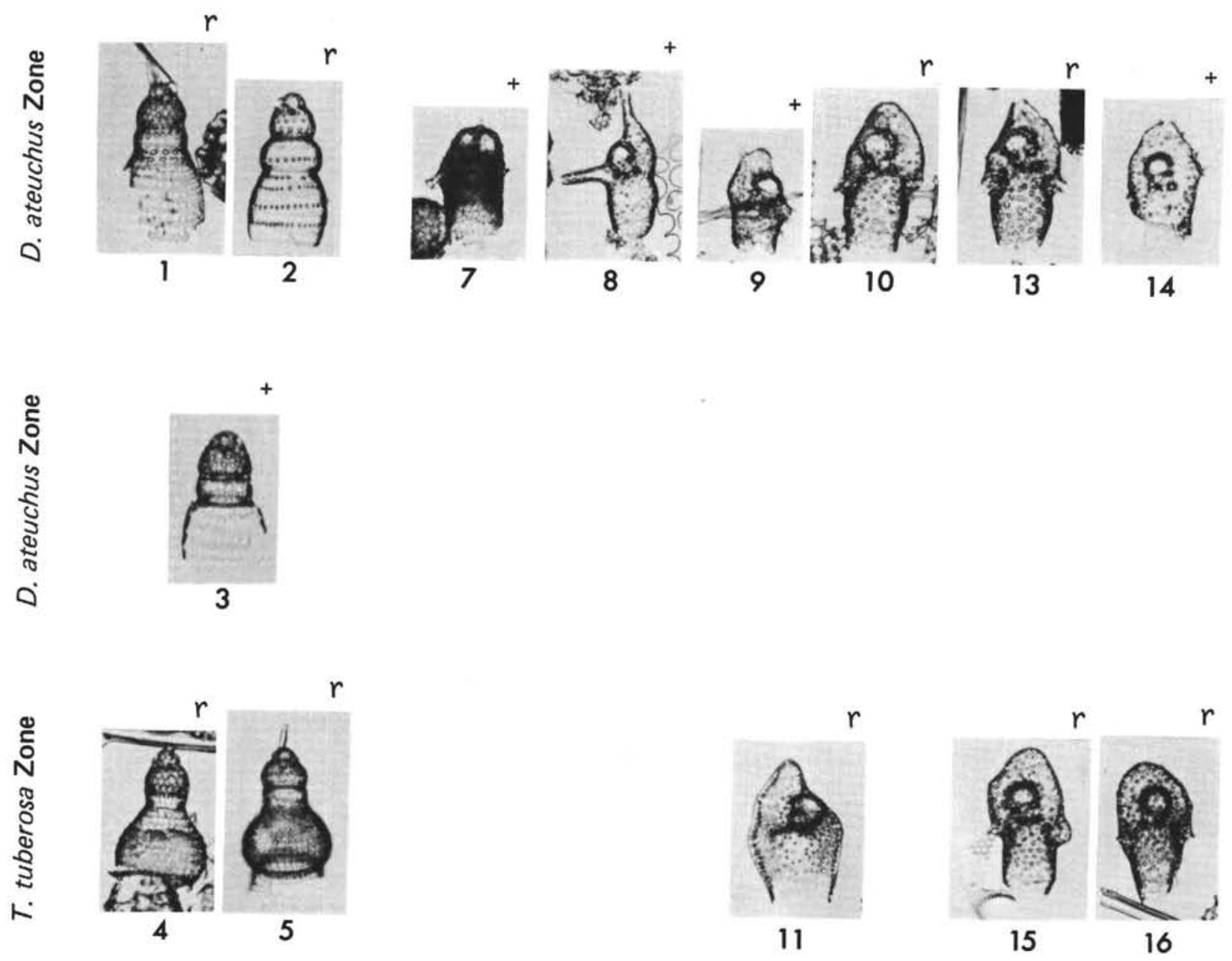

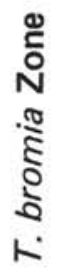
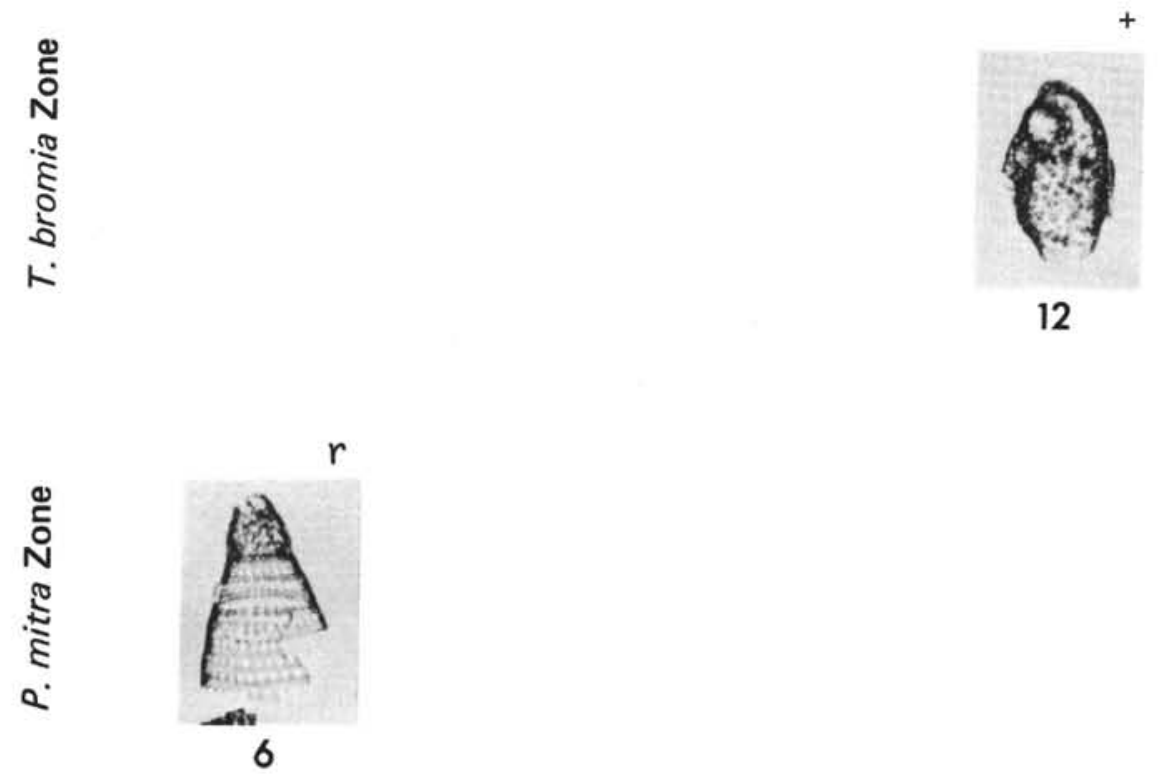


\section{PLATE 4}

Figures 1, 2 Solenosphaera omnitubus Riedel and Sanfilippo, n. sp.

1: Holotype, 62.1-22-2, $84-86 \mathrm{~cm}$, Sl. 1, V32/0 $(255 \times)$

2: $62.1-22-2,84-86 \mathrm{~cm}, \mathrm{Sl} .1, \mathrm{C} 29 / 2,(255 \mathrm{X})$.

Figure 3

Dorydruppa sp. or Doryprunum sp. 62.0-5-2, 84-86 cm, Sl. 1, Q19/4 (150X).

Figure $4 \quad$ Doryphacus sp.

WRE-100, Sl. 2, V21/0 (150X).

Figure $5 \quad$ Cannartus prismaticus (Haeckel) 64.0-9-CC, Ph. 1, V12/0 (165X).

Figure $6 \quad$ Ommartartus avitus (Riedel)

66.1-3-1, 55-57 cm, Ph. 1, Y20/0 (165X).

Figures 7, 8 Spongaster klingi Riedel and Sanfilippo, n. sp.

7: Holotype, 66.1-3-5, 25-27 cm, Sl. 1, M15/2 (95X).

8: Specimen with distinct pylome-tube, 66.1-5-3, 30-32 cm, Cse. 1, F52/3 (150X).

Figures 9-11 Dictyocoryne ontongensis Riedel and Sanfilippo, n. sp. 9: Holotype, 66.1-5-3, 30-32 cm, Cse. 1, Q31/4 $(150 \times)$.

10: Specimen with short and wide bifurcations, 66.1-6-4, 25-27 cm, Cse. 1, E39/0 (150X).

11: Specimen with double bifurcations, 66.1-5-1, 25-27 cm, Cse. $1, \mathrm{~N} 21 / 0$ (150X). 

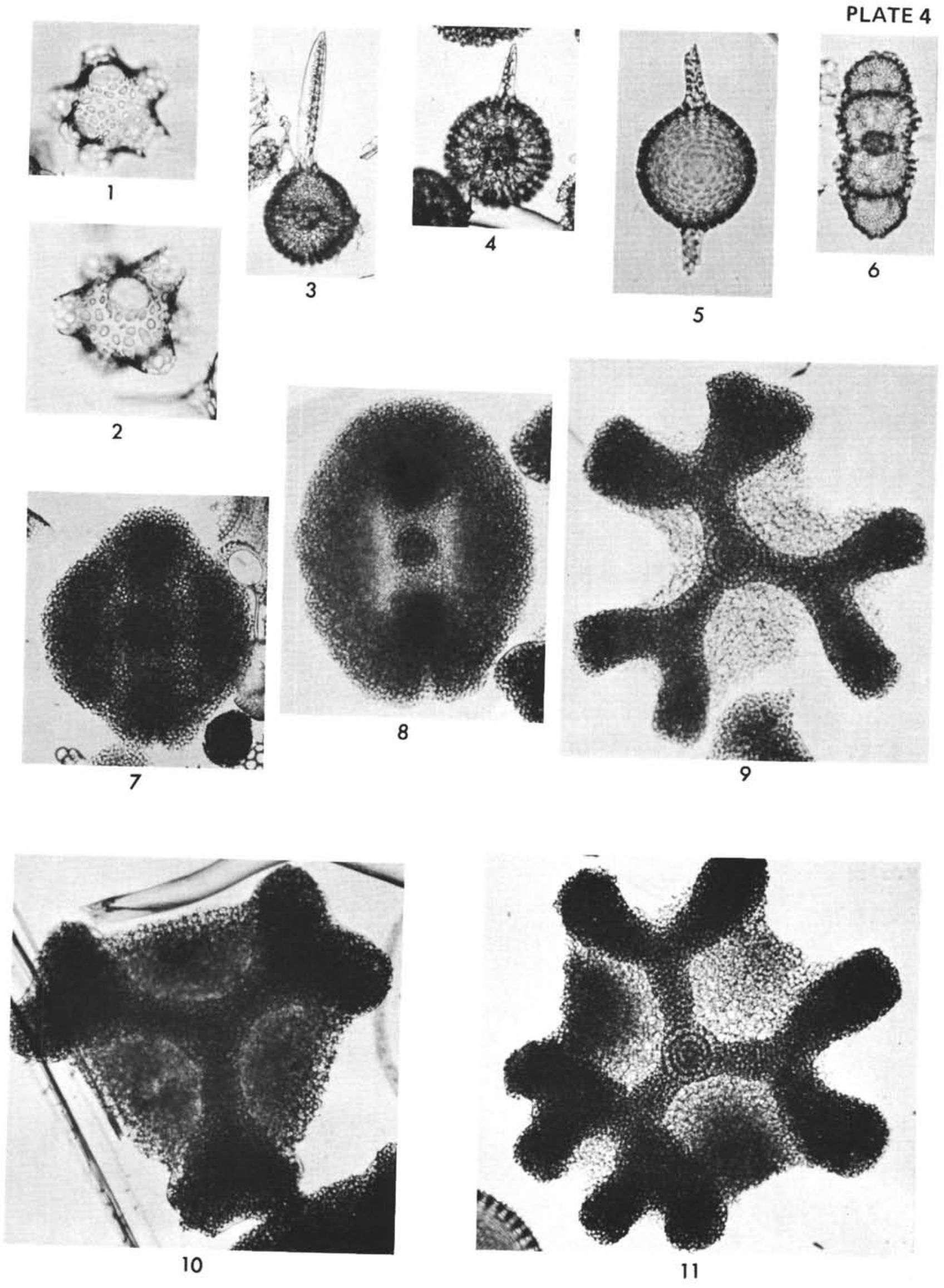


\section{PLATE 5}

Figure 1 Spongodiscid, gen. et sp. indet., similar to Spongaster but evidently not related. $66.1-8-3,25-27 \mathrm{~cm}, \mathrm{Ph} .1$, G25/0 (150X).

Figure 2 Dorcadospyris simplex (Riedel)

WRE-96, SI. 2, H58/2 (150X).

Figure 3 Dorcadospyris sp. aff. D. dentata Haeckel La Mirada, Mallorca, No. 2, Y14/4 (165X).

Figure 4 Liriospyris parkerae Riedel and Sanfilippo, n. sp. 66.1-8-3, 25-27 cm, Ph. 1, Z28/2 (255X).

Figures 5-7 Dendrospyris anthocyrtoides (Bütschli)

5: $66.0-3-4,25-27 \mathrm{~cm}$, Cse. 2, H29/3 (150X).

6: 66.0-3-CC, S1.1, T39/0 (150X).

7: $66.0-3-5,125-127 \mathrm{~cm}$, Cse. $2, \mathrm{~S} 12 / 0(150 \mathrm{X})$.

Figures 8-10 Psychospyris parva Riedel and Sanfilippo, n. sp. 8: $66.0-3-5,125-127 \mathrm{~cm}$, Cse. 2, D32/4 (150X).

9: Holotype, 66.0-3-5, 25-27 cm, Cse. 1, T23/0 (150X)

10: $66.0-3-5,125-127 \mathrm{~cm}$, Cse. $1, \mathrm{U1} 2 / 4$ (150X).

Figure 11 Psychospyris intermedia Riedel and Sanfilippo, n. sp. Holotype, 66.0-3-3, 25-27 cm, Cse. 1, E41/0 (150X). 

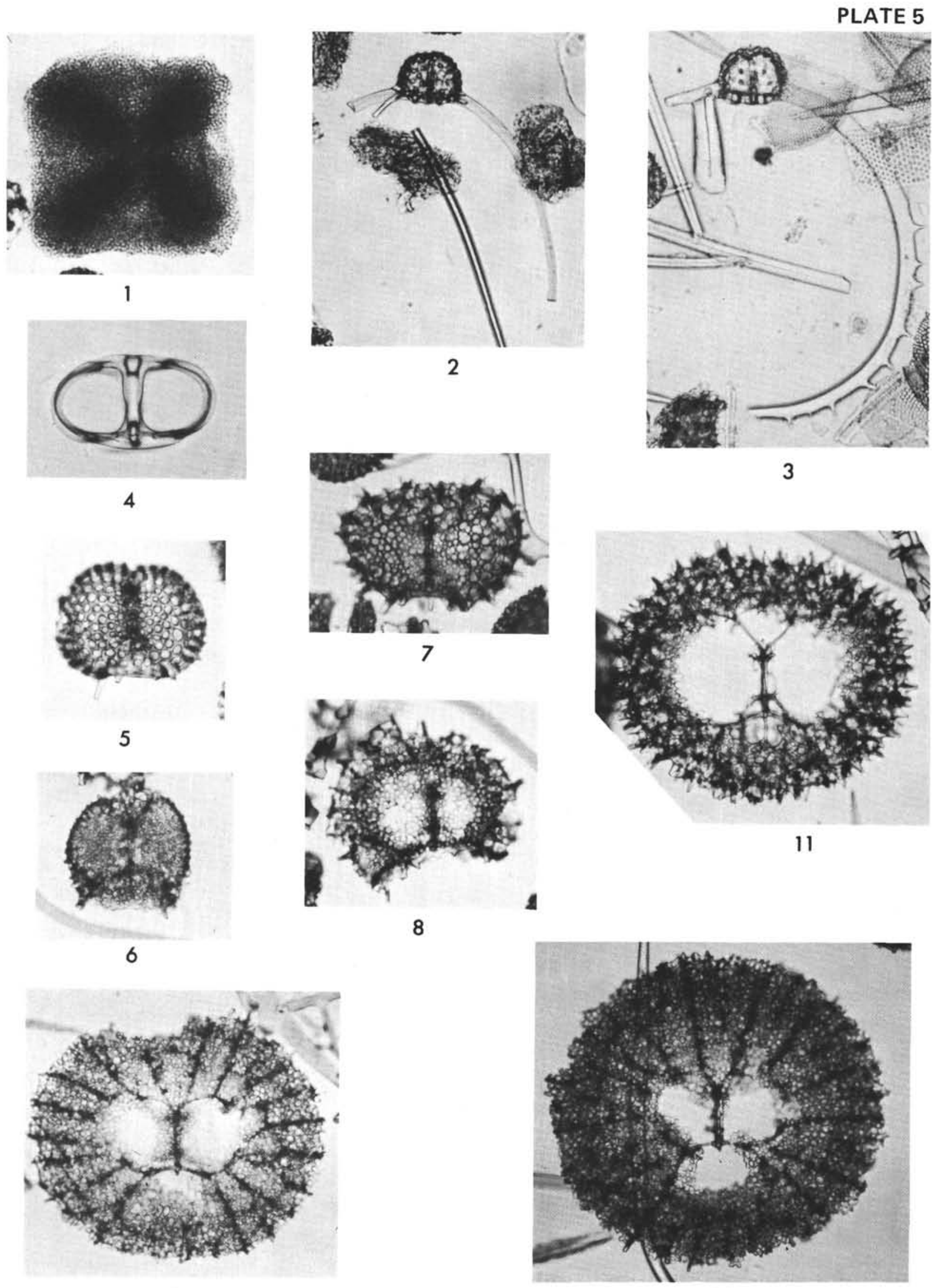
10 


\section{PLATE 6}

Figures 1,2 Psychospyris intermedia Riedel and Sanfilippo, n. sp. 1: $66.0-3-1,125-127 \mathrm{~cm}$, Cse. 1, E40/0 (150X).

2: 66.0-2-CC, Cse. 1, W44/4 (150X).

Figures 3-5 Psychospyris grandis Riedel and Sanfilippo, n. sp. 3: 66.0-2-CC, Cse. 1, Q50/4 (150X).

4: $66.0-2-3,25-27 \mathrm{~cm}, \mathrm{Cse} .2, \mathrm{U} 47 / 4$ (150X).

5: Holotype, 66.1-8-CC, Cse. 2, U32/0 (150X).

Figure $6 \quad$ Artophormis dominasinensis (Ehrenberg) 65.0-16-CC, Sl. 1, U33/0 (165X).

Figure $7 \quad$ Artophormis gracilis Riedel

Ca'Lombasini, near Salsomaggiore, Italy, WRE-107, S1. 2, S23/2 (165X).

Figure $8 \quad$ Bekoma sp.

Belus, France, C2.712, L30/3 (165X). 

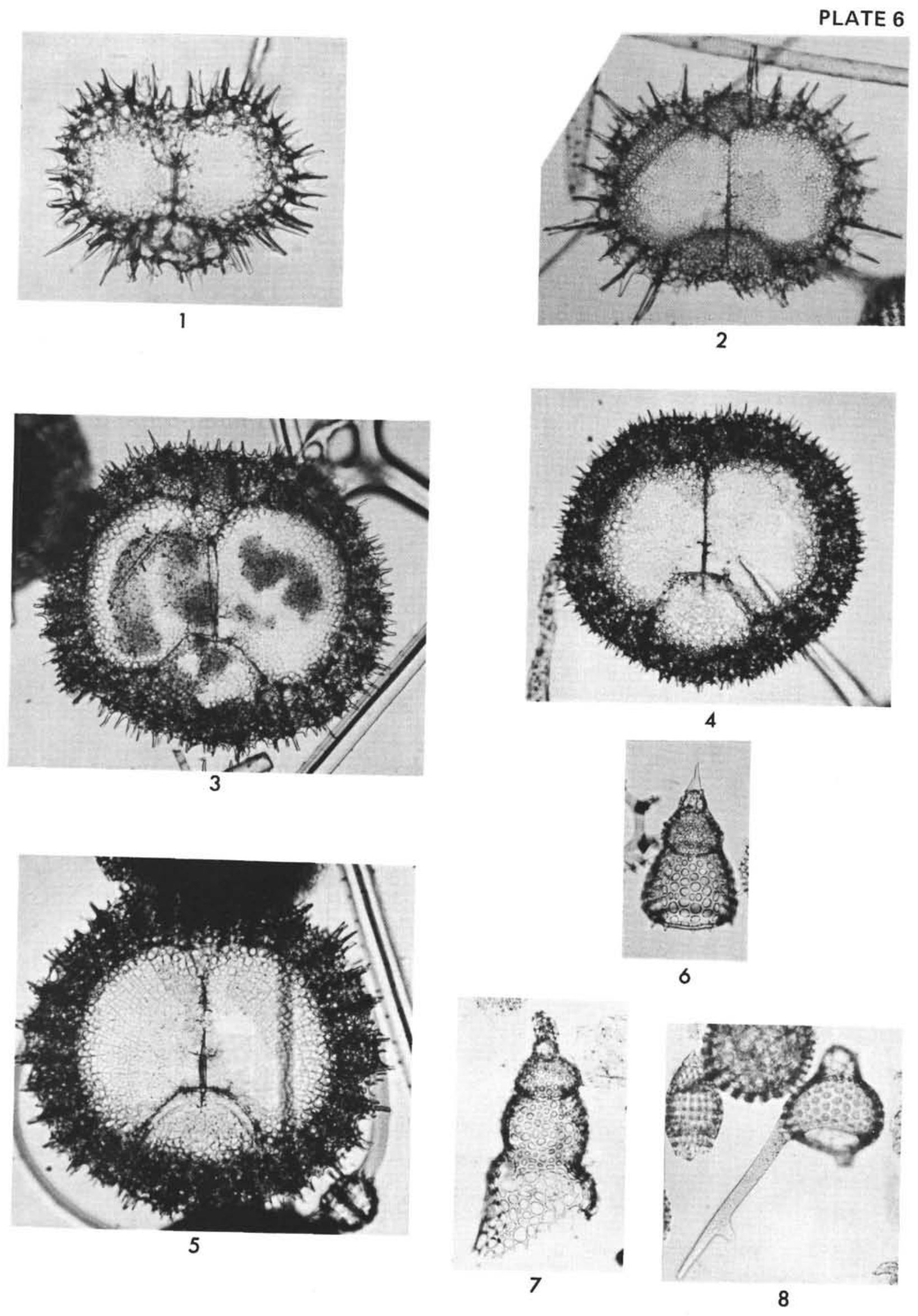


\section{PLATE 7}

Figures 1-4

Bekoma bidarfensis Riedel and Sanfilippo, n. sp. Ibbaritz-Bidarf, France,

1: Holotype, Cl. 4571/2, L22/2 (165X).

2: Cl. $456 \frac{1}{2}, \mathrm{M} 27 / 1$ (165X).

3: side view of two feet joined by bar distally, $\mathrm{Cl}$. $456 \frac{1}{2}, \mathrm{Q} 21 / 4(165 \mathrm{X})$.

4: plan view of bar joining two feet distally, $\mathrm{Cl}$. $455 \frac{1}{2}, \mathrm{P} 22 / 3(165 \mathrm{X})$.

Figures 5-7 Bekoma bidarfensis Riedel and Sanfilippo, n. sp. 67.1-2-CC,

5: $\mathrm{Ph} .2, \mathrm{X} 34 / 3(165 \mathrm{X})$

6: Ph. 2, Z24/2 (165X).

7: Sl. 2, V14/3 (165X).

Figures 8,9 Cyclampterium(?) milowi Riedel and Sanfilippo, n. sp.

8: Holotype, 65.0-14-1, 25-27 cm, Cse. 1, S35/1 (95X).

9: same sample, Cse. 1, D20/2 (95X).

Figures 10,11 Eucyrtidium cubense Riedel and Sanfilippo, n. sp. 67.1-2-CC,

10: Holotype, S1. 2, G11/4 (165X).

11: Ph. 2, J13/4 (165X).

Figure 12 Lithocampium sp. A

67.1-2-CC, S1. B, D36/1 (165X).

Figure 13 Lithochytris archaea Riedel and Sanfilippo 67.1-2-CC, Sl. 1, O24/3 (165X).

Figure 14 Lithopera renzae Sanfilippo and Riedel

La Mirada, Mallorca, No. 3, W28/0 (255X).

Figure $15 \quad$ Lithopera sp. aff. L. renzae

La Mirada, Mallorca, No. 3, S23/3 (255X).

Figure $16 \quad$ Lophocyrtis (?) jacchia (Ehrenberg)

64.1-9-1, 30-32 cm, Sl. 1, T10/3 (150X). 


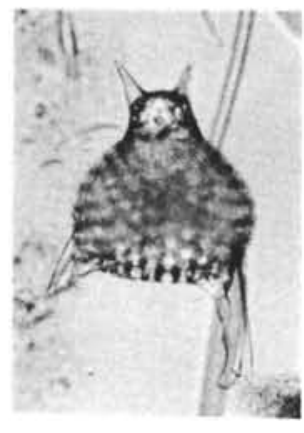

1

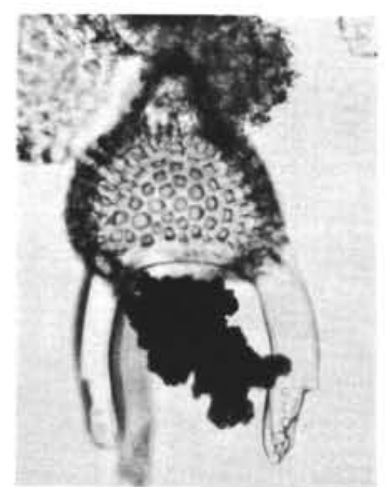

5

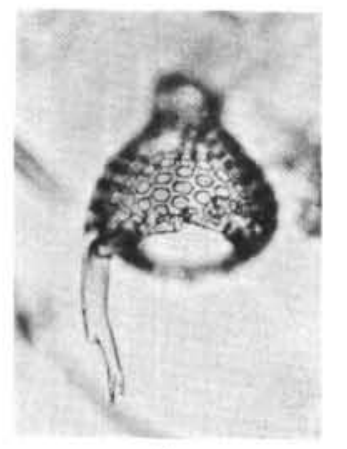

2

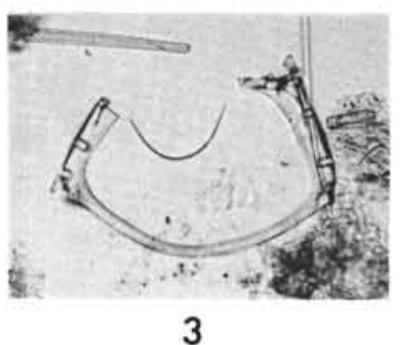

PLATE 7
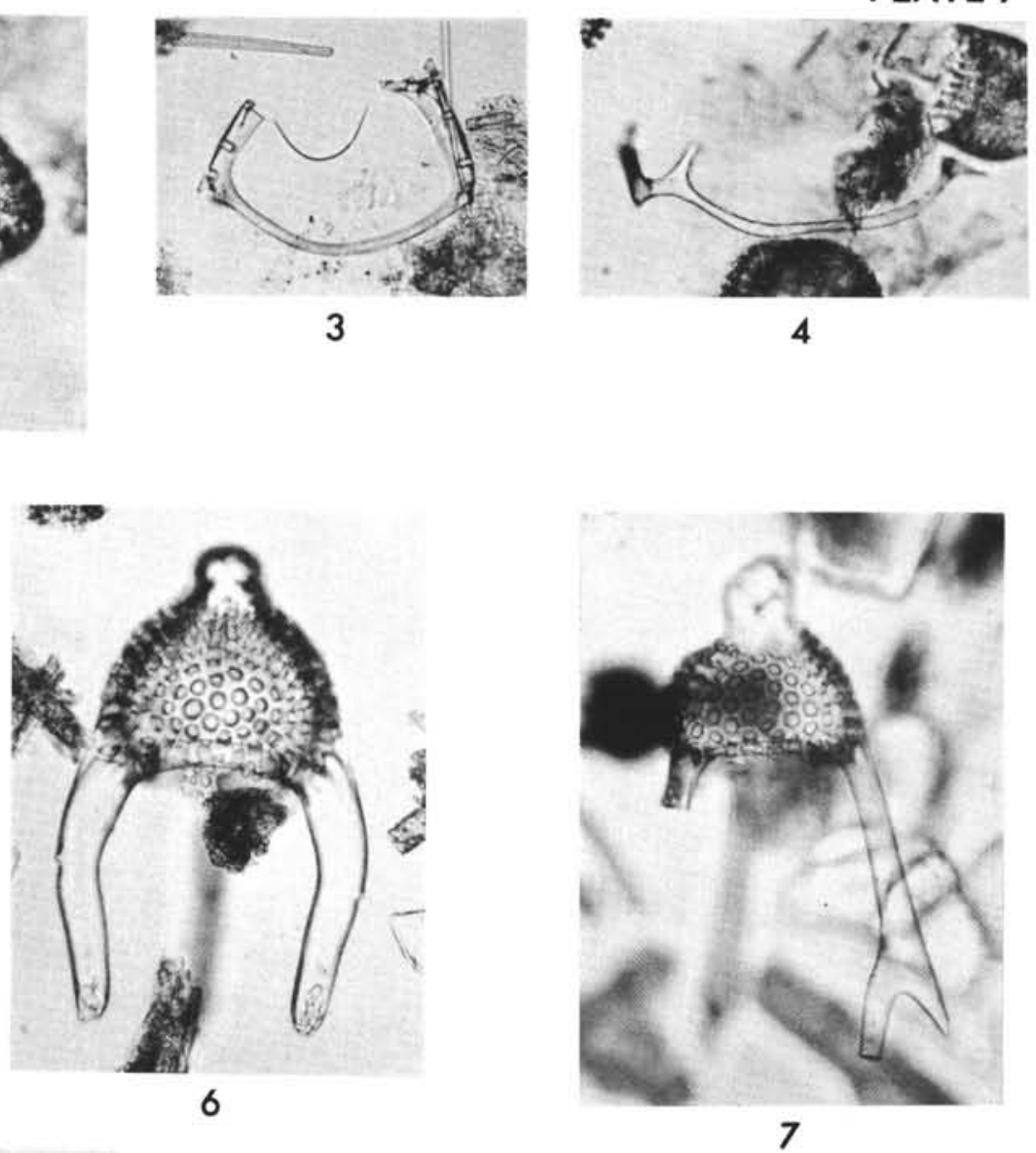

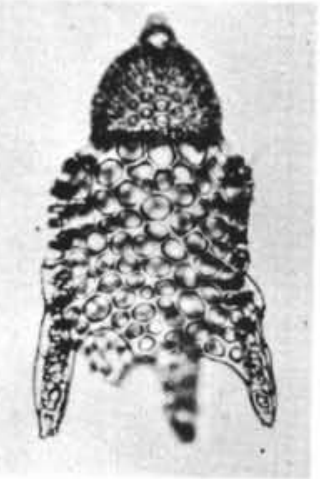

8

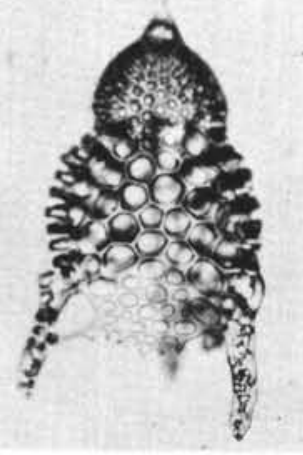

9

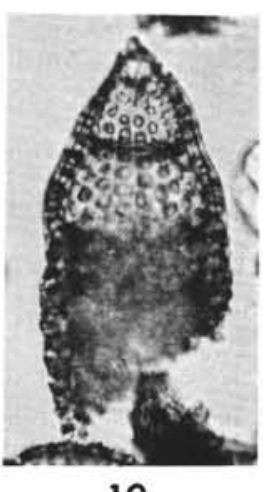

10

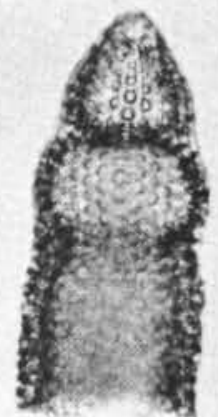

11

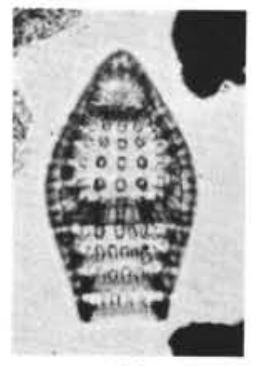

12

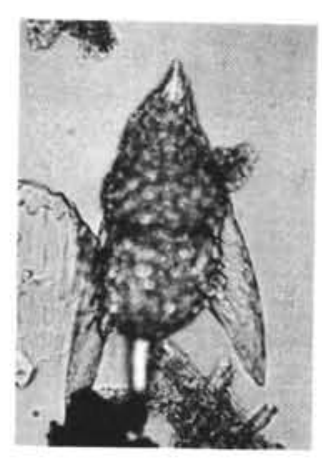

13

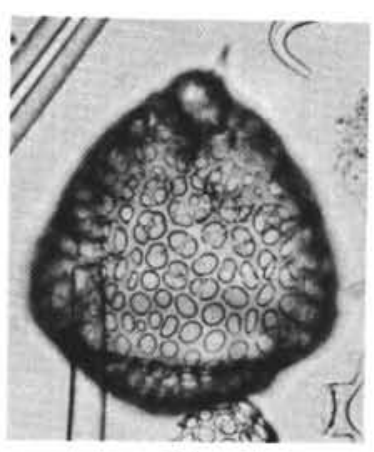

14

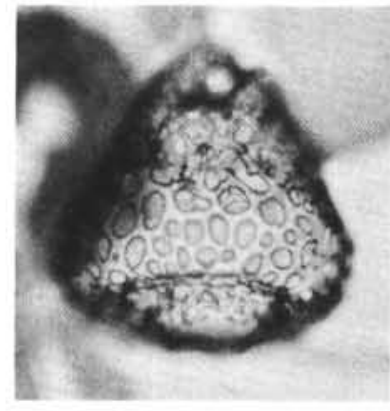

15

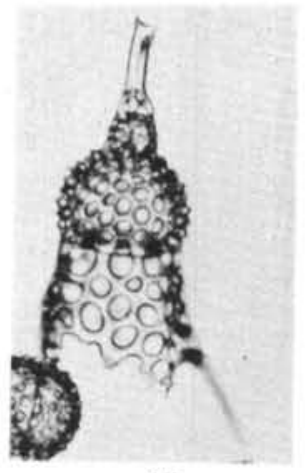

16 


\section{PLATE 8}

Figure $1 \quad$ Pterocanium prismatium Riedel 66.1-2-3, 25-27 cm, Ph. 1 (255X).

Figures 2, 3 Lychnocanium trifolium Riedel and Sanfilippo, n. sp.

2: Holotype, 64.0-8-CC, Sl. 1, V42/2 (150X).

3: same slide, V35/2 (150X).

Figure $4 \quad$ Phormocyrtis striata Brandt

Specimen with abdomen triangular in section, 67.1-2. CC, Sl. 1, B42/4 (165X).

Figure $5 \quad$ Stichocorys peregrina (Riedel)

Tabianian 6509, S12/0 (255X).

Figure $6 \quad$ Thyrsocyrtis bromia Ehrenberg 65.0-16-CC, S1. 1, S42/1 (165X).

Figure 7 Carpocanopsis bramlettei Riedel and Sanfilippo, n. sp. Holotype, 63.1-14-1, 10-12 cm, N25/0 (255X).

Figure 8 Carpocanopsis cingulatum Riedel and Sanfilippo, n. sp. Holotype, 63.1-14-1, 10-12 cm, Sl. 1, P36/0 (255X).

Figures 9-11 Carpocanopsis favosum (Haeckel)

9: $66.0-3-1,25-27 \mathrm{~cm}$, Sl. 1, H17/0 (255X).

10: Specimen with thick wall obscuring external lumbar stricture, $64.1-4-3,84-86 \mathrm{~cm}$, Sl. 1, J37/3 (255X).

11: Specimen with unusually long peristome (abdomen), 62.0-4-CC, Sl. 1, V40/0 (255X).

Figure 12 Calocycletta sp. cf. C. virginis Haeckel 63.0-4-CC, Sl. 1, H18/4 (165X).

Figure 13 Podocyrtis goetheana (Haeckel) 65.1-5-CC, Cse. 1, Q43/4, (150X).

Figures 14, 15 Artostrobium doliolum Riedel and Sanfilippo, n. sp. 14: Holotype, 66.1-4-3, 25-27 cm, Ph. 1, N21/4, (255X).

15: same sample, Sl. 1, Q46/0 (255X). 
PLATE 8
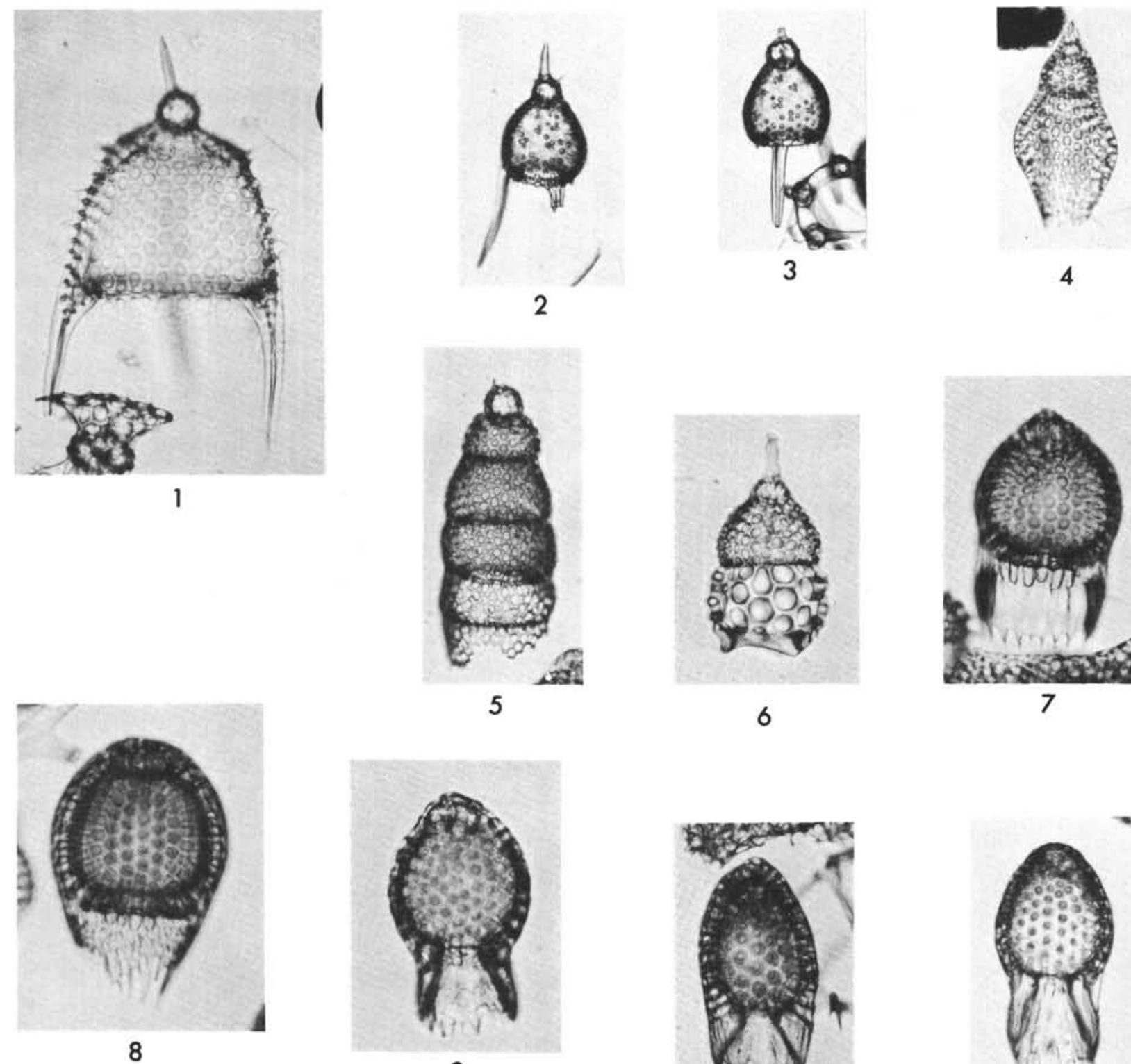

5
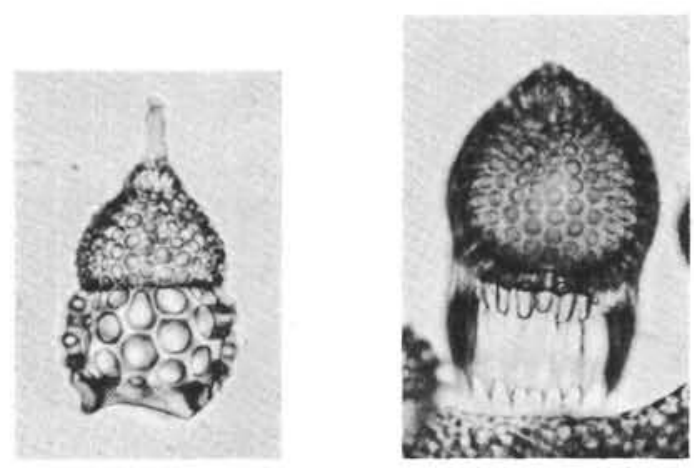

6
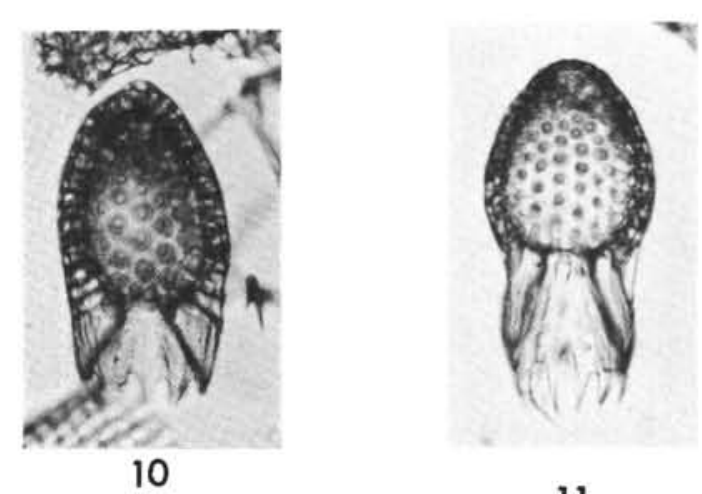

11
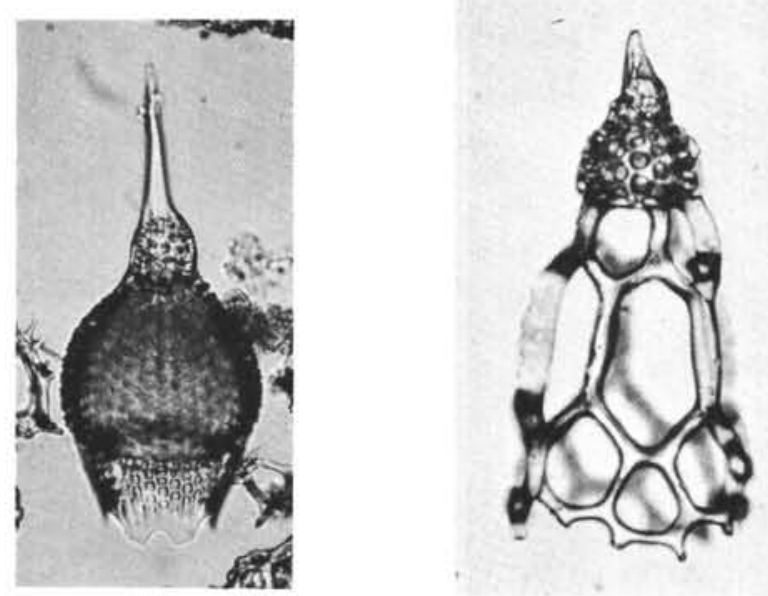

13

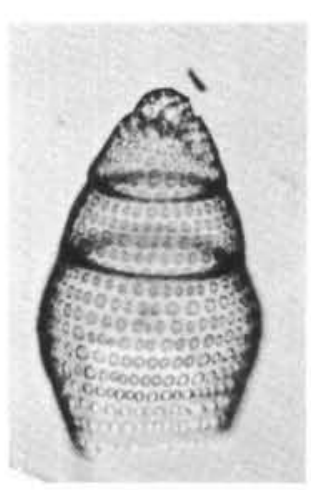

14

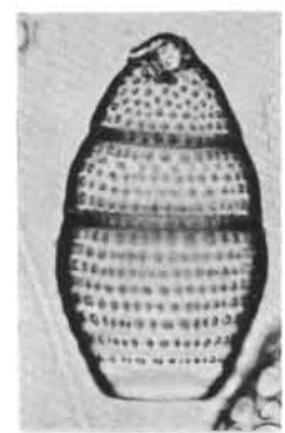

15 


\section{INDEX OF RADIOLARIAN NAMES}

Only genus-group and species-group taxa are indexed. In order to facilitate use of the index for taxa for which there are many entries, the principal reference and illustrations are printed in bold face, and this is preceded by entries referring to brief mentions in discussion, and followed by entries referring to occurrences and stratigraphic range.

\section{Acanthocyrtis, 1600}

Acrobotrys, 1601; 1602

tritubus, 1602; Pl. 1J, figs. 19, 20; 1538; 1546; $1552 ; 1556 ; 1560 ; 1562 ; 1563 ; 1580 ; 1579$

spp. 1601; Pl. 1J, figs. 12-16; Pl. 2J, figs. 13-15; Pl. 3F, fig. $8 ; 1538 ; 1546 ; 1552 ; 1556 ; 1560 ; 1584$

Anthocyrtis hispida, 1593

Artophormis, 1592

barbadensis 1605; 1592; Pl. 3B, figs. 8, 9; 1534; $1542 ; 1550 ; 1554 ; 1558 ; 1570 ; 1572 ; 1575 ; 1584$ dominasinensis, 1592; Pl. 6, fig. 6; 1534; 1542; $1550 ; 1554 ; 1558 ; 1571 ; 1574$;

gracilis, $1582 ; 1605 ; 1592$; PI. 3B, figs. 5-7; Pl. 6, fig. $7 ; 1534 ; 1542 ; 1550 ; 1554 ; 1558 ; 1569 ; 1570$; $1549 ; 1575 ; 1584$

Artostrobium, 1599

auritum group, 1599; PI. 1H, figs. 5-8; 1538; 1546; $1552 ; 1556 ; 1560$

doliolum 1586; 1599; PI. 1H, figs. 1-3; Pl. 8, figs. 14,$15 ; 1538 ; 1546 ; 1552 ; 1556 ; 1560 ; 1562 ; 1565$; $1580 ; 1578$

miralestense 1599; PI. 1H, figs. 9-17; Pl. 2I, figs. 9, 10; Pl. 3E, fig. 12;1546;1552; 1560

sp. aff. A. doliolum Pl. 1H, fig. 4; PI. 2I, figs. 1-8; Pl. 3E, figs. 7-9

Astromma aristotelis, 1588

Bekoma, 1592; 1545

bidarfensis 1592; Pl. 7, figs. 1-7; 1545

sp. P1. 6, fig. 8

Bisphaerocephalina , 1602

Botryocella, 1602 multicellaris 1602

Botryocyrtis, 1602 spp. 1602; PI. 1J, figs. 1-11; Pl. 2J, figs. 10-12; Pl. $3 \mathrm{~F}$, fig. $7 ; 1538 ; 1546 ; 1552 ; 1556 ; 1560 ; 1568$; $1549 ; 1577 ; 1584$

Botryopyle 1602 dictyocephalus, 1602

dictyocephalus group, 1602; Pl. 1J, figs. 21-26; PI. 2J, figs. 16-18; Pl. 3F , figs. 9-12; 1538; 1546; 1552; $1556 ; 1560 ; 1584$

sp. A 1602; Pl. 2J, figs. 20, 21; PI. 3F , fig. 13; 1538; $1546 ; 1552 ; 1556 ; 1560 ; 1567 ; 1569 ; 1549 ; 1576$; 1584

Brachiospyris alata, 1590 simplex, 1590
Calocyclas barbadensis, 1592

costata 1598

turris 1593

virginis 1598

Calocycletta, 1598

costata, 1582; 1598; Pl. 2H, figs. 12-14; 1532; $1538 ; 1546 ; 1552 ; 1556 ; 1560 ; 1566 ; 1567 ; 1549$; $1577 ; 1584$

virginis, 1582; 1598; Pl. 2H, figs. 5-11; 1532; 1538; $1546 ; 1552 ; 1556 ; 1560 ; 1565 ; 1568 ; 1549 ; 1576$; 1584

sp. cf. C. virginis, Pl. 8, fig. 12

sp. 1598; Pl. 1G, figs. 17, 18; Pl. 2H, figs. 1-3; 1538; $1546 ; 1552 ; 1560 ; 1563$

Calocycloma, 1593

(?) ampulla, 1593; PI. 3B, fig. 4; 1534; 1550; 1554; $1558 ; 1572 ; 1574$

Cannartidium mammiferum, 1587

Cannartus, 1587

laticonus, 1587; Pl. 1C, figs. 13, 14; 1534; 1542; $1550 ; 1554 ; 1558 ; 1564 ; 1565 ; 1580 ; 1578 ; 1584$ mammiferus, 1587; PI. 2C, figs. 1-3; 11; 1534; $1542 ; 1550 ; 1554 ; 1558 ; 1565 ; 1566 ; 1549 ; 1580$; $1578 ; 1584$

(?) petterssoni, 1587; Pl. 1C, figs. 19, 20; 1534; $1542 ; 1550 ; 1554 ; 1558 ; 1563 ; 1565 ; 1549 ; 1580$; $1578 ; 1584$

(?) sp. aff. $C$. (?) petterssoni, PI. 1C, figs. 15, 16

prismaticus, $1587 ; 1588$; Pl. 2C, figs. 11-13; Pl. 4, fig. $5 ; 1534 ; 1542 ; 1550 ; 1554 ; 1558 ; 1566 ; 1570$; $1549 ; 1576 ; 1584$

(?) sp. aff. C. prismaticus, Pl. 2C, fig. 14

tubarius, 1587; 1588; Pl. 2C, figs. 8-10; 1534; 1542; $1550 ; 1554 ; 1558 ; 1567 ; 1568 ; 1544 ; 1577 ; 1584$ violina, 1588; P1. 2C, figs. 4-7; 1532; 1534; 1542; $1550 ; 1554 ; 1558 ; 1566 ; 1567 ; 1549 ; 1577 ; 1584$ sp., 1587; Pl. 1D, fig. 1; Pl. 2B, figs. 9, 10; 1582

Cantharospyris ateuchus, 1590

Carpocanarium, 1596; 1599

spp., 1599; Pl. 1I, figs. 17-25; Pl. 2J, figs. 8, 9; $1538 ; 1546 ; 1552 ; 1556 ; 1560 ; 1563 ; 1580 ; 1579$

Carpocanistrum, 1596 evacuatum, 1596

spp., 1596; Pl. 1G, figs. 1-6, 7(?), 8-13, 14(?), 1538(?); Pl. 2F, figs. 5-16; Pl. 3D, figs. 1, 2, 3-5(?) 6, 7, 8(?), 9; 1534;1540;1552; 1556; 1560

Carpocanium, 1596 calycothes, $1599 ; 1600$

Carpocanopsis, 1596 bramlettei, 1597; Pl. 2G, figs. 8-14; Pl. 8, fig. 7; $1532 ; 1538 ; 1546 ; 1552 ; 1556 ; 1560 ; 1565 ; 1568$; $1549 ; 1580 ; 1577 ; 1584$

cingulatum, 1582; 1596; 1597; PI. 2G, figs. 17-21; Pl. 8, fig. 8; 1532; 1538; 1546; 1552; 1556; 1560; $1567 ; 1569 ; 1549 ; 1576 ; 1584$

cristatum, 1597; Pl. 1G, fig. 16; Pl. 2G, figs. 1-7; $1538 ; 1546 ; 1552 ; 1556 ; 1560 ; 1564 ; 1567 ; 1549$; $1580 ; 1577 ; 1584$ 
favosum, 1597; PI. 2G, figs. 15, 16; Pl. 8, figs. 9-11; $1532 ; 1538 ; 1546 ; 1552 ; 1556 ; 1560 ; 1566 ; 1568$; $1549 ; 1577 ; 1584$

Centrobotrys, 1602 thermophila, 1602; Pl. 1J, figs. 27-31 ; Pl. 2J, fig. 19; PI. 3F, fig. 14; 1538; 1546; 1552; 1556; 1560; 1584 sp. A, 1602; Pl. 3F, figs. 15, 16; 1538; 1546; 1552; $1556 ; 1560 ; 1569 ; 1570 ; 1549 ; 1576 ; 1584$

Ceratospyris ateuchus, 1590 triceros, 1592

Chitonastrum, 1589

dicranodes, 1589

jugatum, 1589

lyra, 1589

Collosphaera, 1586

(?), Pl. 1A, fig. 1; Pl. 2A, fig. 3

spp., Pl. 1A, figs. 2-11; Pl. 2A, figs. 1, 2

Cornutella obtusa, 1600

Cryptoprora ornata, 1597; Pl. 3D, figs. 10, 11

Cycladophora, 1593

favosa, 1597

goetheana, 1598

hispida, 1593; Pl. 3B, figs. 10, 11; 1534; 1542; $1550 ; 1554 ; 1558 ; 1571 ; 1574 ; 1583$

turris, $1593 ; 1534 ; 1542 ; 1550 ; 1554 ; 1558 ; 1572$; $1573 ; 1575$

Cyclampterium, 1593

(?), 1586

(?) brachythorax, 1593; Pl. 1E, fig. 7; 1534; 1542;

$1550 ; 1554 ; 1558 ; 1563 ; 1564 ; 1580 ; 1578$

(?) leptetrum 1593; Pl. 2D, figs. 9-12; 1532; 1534; $1542 ; 1550 ; 1554 ; 1558 ; 1565 ; 1567 ; 1549 ; 1577$; 1584

(?) milowi, 1586; 1594; Pl. 3B, fig. 3; Pl. 7, figs. 8 , $9 ; 1534 ; 1542 ; 1550 ; 1554 ; 1558 ; 1569 ; 1571$; $1549 ; 1575$

(?) neatum, 1593; Pl. 1E, figs. 4-6; 1534; 1542; $1550 ; 1554 ; 1558 ; 1563 ; 1580 ; 1579$

(?) pegetrum, 1582;1586; 1593; Pl. 2D, figs. 13, 14; Pl. 3B, figs. 1, 2; 1534; 1542; 1550; 1554; 1558; $1567 ; 1569 ; 1549 ; 1576 ; 1584$

(?) tany thorax, 1593; Pl. 1E, figs. 8-10; PI. 2D, figs. 7,$8 ; 1534 ; 1542 ; 1550 ; 1554 ; 1558 ; 1564 ; 1565$; $1580 ; 1578 ; 1584$

(?) sp., 1593

Cyrtocapsa cornuta, 1593

diploconus, 1595

tetrapera, 1594

Cyrtocapsella, 1593

cornuta, 1593; Pl. 2E, figs. 1-4; 1532; 1534; 1542; $1550 ; 1554 ; 1558 ; 1564 ; 1568 ; 1580 ; 1576 ; 1584$ elongata, $1534 ; 1542 ; 1550 ; 1558$

japonica, 1593; Pl. 1F, fig. 1; Pl. 2E, fig. 12; 1534; $1542 ; 1550 ; 1554 ; 1558 ; 1584$

tetrapera, 1594; PI. 2E, figs. 5-7; 1534; 1542; 1550; $1554 ; 1558 ; 1565 ; 1569 ; 1549 ; 1576 ; 1584$

Cyrtophormis, 1600

armata, 1595; 1600 corona, 1600

cylindrica, 1600

Dendrospyris , 1590

anthocyrtoides, $1586 ; 1591 ; 1590 ;$ Pl. 5, figs. 5-7

Dictyastrum, 1589

Dictyocephalus bergontianus, 1599

miralestensis, 1599

papillosus, 1599

Dictyocoryne, 1588 ontongensis, 1588; Pl. 1E, figs. 1, 2; Pl. 4, 9-11; $1534 ; 1542 ; 1550 ; 1554 ; 1558 ; 1563 ; 1564 ; 1580$; 1579

Dictyocryphalus, 1599 papillosus, 1599

Dictyomitra ferminensis, 1599 montereyana, 1599

Dictyophimus babylonis, 1595

Dictyopodium eurylophos, 1593 oxylophos, 1593

Dipospyris forcipata, 1590

Dorcadospyris, 1590 alata, 1582; 1590; Pl. 2D, fig. 1; 1534; 1542; 1550; $1554 ; 1558 ; 1564 ; 1566 ; 1549 ; 1580 ; 1578 ; 1584$ ateuchus, 1586; 1590; Pl. 2D, fig. 6; Pl. 3A, figs. 9, $10 ; 1534 ; 1542 ; 1550 ; 1554 ; 1558 ; 1568 ; 1570$; $1549 ; 1576 ; 1584$

dentata, 1590; Pl. 2D, figs. 2, 3; 1532; 1534; 1542; $1550 ; 1554 ; 1558 ; 1566 ; 1567 ; 1549 ; 1577 ; 1584$ forcipata, 1590; Pl. 2C, figs. 20-23; Pl. 3A, fig. 8; $1534 ; 1542 ; 1550 ; 1554 ; 1558 ; 1566 ; 1570 ; 1549$; $1576 ; 1584$

papilio, 1590; Pl. 2D, figs. 4, 5; Pl. 3A, fig. 7; 1534; $1542 ; 1550 ; 1554 ; 1558 ; 1568 ; 1569 ; 1549 ; 1576$ simplex, 1582; 1590; Pl. 5, fig. 2; 1584

sp. aff. D. dentata, Pl. 5, fig. 3; 1582

Dorydruppa, 1587 sp., 1582; Pl. 4, fig. 3

Doryphacus, 1587 sp., Pl. 4, fig. 4; 1584; 1582

Doryprunum, 1587 sp., 1582; Pl. 4, fig. 3

Euchitonia, 1589

Eucyrtidium, 1594

ampulla, 1593

armadillo, 1601

cubense, 1594; Pl. 7, figs. 10, 11; 1545

delmontense, 1595

elongatum peregrinum, 1595

ficus, 1596

fistuligerum, 1594

lineatum arachneum, 1600

mongolfieri, 1601

pachyderma, 1600

papillosum, 1599; 1600 
pirum, 1601

tumidulum, 1599

Eusyringium, 1594

fistuligerum, 1594; PI. 3B, fig. 14; 1534; 1550;

$1554 ; 1558 ; 1572 ; 1574 ; 1583 ; 1585$

japonicum, 1593

lagena (?), 1594; 1534; 1550;1554; 1583; 1585

Hexaspyris papilio, 1590

Liriospyris elevata, 1590; PI. 1E, fig. 3; 1534; 1542; $1550 ; 1554 ; 1558 ; 1563 ; 1565 ; 1580 ; 1578 ; 1584$ parkerae, $1586 ; 1591 ; 1590 ;$ Pl. 2C, fig. 15; PI. 5, fig. $4 ; 1534 ; 1542 ; 1550 ; 1554 ; 1558 ; 1565 ; 1566$; $1549 ; 1578 ; 1584$ stauropora, 1586; 1591; 1590; PI. 2C, figs. 16-19; $1534 ; 1542 ; 1550 ; 1554 ; 1558 ; 1566 ; 1567 ; 1549$; $1549 ; 1577 ; 1584$

Lithapium, 1587

(?) anoectum, 1587; 1583

Lithobotrys geminata, 1601

Lithocampe aurita, 1599

corbula, 1601

lineata, 1599; 1600

solitaria, 1596

Lithocampium, 1594

sp. A, 1594; Pl. 7, fig. 12; 1545

sp., $1594 ; 1545 ; 1583$

Lithocarpium, 1596

pyriforme, 1596

Lithochytris, 1594

archaea, 1594; Pl. 7, fig. 13; 1545

verpertilio, 1594; 1534; 1550;1558; $1573 ; 1585$

Lithocyclia, 1587; 1588

angustum, 1586; 1587; 1588; Pl. 3A, figs. 1, 3;

$1542 ; 1550 ; 1554 ; 1558 ; 1569 ; 1570 ; 1549 ; 1575$; 1584

sp. cf. L. angustum, PI. 3A, fig. 2

aristotelis group, 1588; Pl. 3A, figs. 4, 5; 1550; $1554 ; 1558 ; 1570 ; 1573 ; 1575 ; 1583 ; 1585$

ocellus, 1588

ocellus group, 1588; Pl. 3A, fig. 6; 1550; 1554; $1558 ; 1545 ; 1571 ; 1574 ; 1583 ; 1585$

Lithomitra, 1600

altamiraensis, 1600

bramlettei, 1599

eruca, 1600

lineata, 1600

lineata group, 1600; Pl. 1I, figs. 1-11; Pl. 2I, figs. 14-16; Pl. 3E, fig. $14 ; 1546 ; 155 ; 1560$

sp. aff. L. lineata group, PI. 1I, fig. 12; Pl. 2I, fig. 17; Pl. 3E, figs. 15-19

nodosaria, 1600

schencki, 1601

Lithopera, 1594

bacca, 1594; PI. 1F , figs. 10-13; 1534; 1542; 1550; $1554 ; 1558 ; 1564 ; 1580 ; 1578$ baueri, 1594; PI. 1F, fig. 9; 1534; 1542; 1550; $1554 ; 1558 ; 1564 ; 1565 ; 1549 ; 1580 ; 1578 ; 1584$ lagena, 1594

neotera, 1594; PI. 1F, figs. 14, 15 ; PI. 2E, fig. 19; $1534 ; 1542 ; 1550 ; 1554 ; 1558 ; 1564 ; 1565 ; 1580$; $1578 ; 1584$

renzae, 1582; 1594; Pl. 2E, figs. 17, 18; Pl. 7, fig. $14 ; 1532 ; 1534 ; 1542 ; 1550 ; 1554 ; 1558 ; 1565$; $1566 ; 1580 ; 1578 ; 1584$

sp. aff. L. renzae, Pl. 7, fig. 15

thornburgi, 1594; PI. 1F, fig. 8; 1534; 1542; 1550;

$1554 ; 1558 ; 1564 ; 1565 ; 1549 ; 1580 ; 1578 ; 1585$

Lithostrobus botryocyrtis, 1599

cf. botryocyrtis, 1600

lithobotrys, 1599

seriatus, 1599

Lophocyrtis, 1594

(?) jacchia, 1594; Pl. 3C, figs. 4, 5; Pl. 7, fig. 16; $1538 ; 1546 ; 1552 ; 1556 ; 1560 ; 1571 ; 1572 ; 1575$

Lychnocanium, 1595

bellum, 1586 ; $1595 ; 1538 ; 1546 ; 1552 ; 1560 ; 1573$; 1574

sp. aff. L. bellum, 1586; 1595; Pl. 3C, figs. 1, 2; $1538 ; 1546 ; 1552 ; 1556 ; 1560 ; 1571 ; 1572 ; 1575$ bipes, 1595; Pl. 2F, figs. 1, 2; 1538; 1546; 1552; $1556 ; 1560 ; 1567 ; 1569 ; 1549 ; 1576 ; 1584$

trifolium, 1595; PI. 3B, fig. 12; Pl. 8, figs. 2, 3; $1538 ; 1546 ; 1552 ; 1556 ; 1560 ; 1569 ; 1549 ; 1576$

Monotubus, 1602

Ommatartus, $1587 ; 1588$

antepenultimus, 1588; Pl. 1C, figs. 11, 12; 1534; $1542 ; 1550 ; 1554 ; 1558 ; 1563 ; 1564 ; 1580 ; 1579$ avitus, 1587; 1588; Pl. 4, fig. 6; 1534; 1542; 1550; $1554 ; 1558 ; 1562 ; 1579 ; 1584$

hughesi, 1587; 1588; Pl. 1C, figs. 17, 18; 1534; $1542 ; 1550 ; 1554 ; 1558 ; 1563 ; 1563 ; 1580 ; 1579$ penultimus, 1588; PI. 1C, figs. 8-10; 1534; 1542; $1550 ; 1554 ; 1558 ; 1562 ; 1563 ; 1580 ; 1579$

tetrathalamus, 1587; 1588; PI. 1C, figs. 5, 6, 7; $1534 ; 1542 ; 1550 ; 1554 ; 1558 ; 1562 ; 1579$

Ommatocampe hughesi, 1588

Panarium antepenultimum, 1588 penultimum, 1588

Panartus avitus, 1588 tetrathalamus, 1588

Petalospyris anthocyrtoides, 1590

Phormocyrtis, 1595

annosa, 1598

striata, 1595; Pl. 8, fig. $4 ; 1545 ; 1582$

Phormostrichoartus, 1600 corona, 1586; 1600; Pl. 1I, figs. 13-15; Pl. 2J, figs. $1-5 ; 1532 ; 1538 ; 1546 ; 1552 ; 1556 ; 1560 ; 1562$; $1567 ; 1549 ; 1577 ; 1584$

sp. aff. P. corona, PI. 1I, fig. 16; Pl. 2J, figs. 6, 7; PI. $3 F$, figs. 1-6 
Pipettaria tubaria, 1588

Pipettella prismatica, 1588

Podocyrtis, 1598

ampla, 1598; 1552; 1556; 1560; 1582; 1583; 1585

aphorma, 1598; 1585

chalara, $1598 ; 1556 ; 1573 ; 1575 ; 1583 ; 1585$

diamesa, $1598 ; 1556 ; 1583$

dominasinensis, 1592

goetheana, 1598; PI. 8, fig. 13; 1556; 1583; 1585

hirsutus, 1596

mitra, 1598; Pl. 3D, fig. 19; 1552; 1556; 1573;

$1574 ; 1583 ; 1585$

papalis, 1598; PI. 3E, fig. 1; 1552; 1556; 1572;

$1574 ; 1583$

sinuosa, 1598; 1552;1556;1573; 1583; 1585

tetracantha, 1596

trachodes, 1552

triacantha, 1596

Polysolenia, 1586

(?), Pl. 1B, figs. 16, 17; Pl. 2B, figs. 1-4

spp., Pl. 1B, figs. 1-15; Pl. 2A, figs. 11-15

Psychospyris, 1586; 1591

grandis, 1586; 1591; Pl. 6, figs. 3-5; 1534; 1542;

$1550 ; 1558 ; 1566 ; 1549$

intermedia, 1586; 1592; 1591; Pl. 5, fig. 11; Pl. 6,

figs. 1,$2 ; 1534 ; 1542 ; 1550 ; 1554 ; 1558 ; 1569$; 1549

parva, $1586 ; 1590 ; 1591$; Pl. 5, figs. 8-10; 1534;

$1542 ; 1550 ; 1554 ; 1558 ; 1569 ; 1549$

spp., 1576

Pterocanium, 1595

prismatium, 1595; Pl. 8, fig. 1; 1538; 1546; 1552;

$1556 ; 1560 ; 1562 ; 1579$

Rhopalodictyum, 1589

bifidum, 1589

Schizodiscus, 1589

Sethochytris, 1595

babylonis group, 1595; Pl. 3B, fig. 13; 1538; 1552;

$1556 ; 1571 ; 1574 ; 1582$

triconiscus (?), 1595; 1538; 1552; 1556; 1573; $1574 ; 1585$

Sethocorys cristata, 1597

Siphocampe, 1601

annulosa, 1660

corbula, 1586; 1601; Pl. 1H, figs. 18-25; 1538;

$1546 ; 1552 ; 1556 ; 1560 ; 1565 ; 1578 ; 1584$

sp. aff. $S$. corbula, PI. 1H, figs. 26-28; Pl. 2I, figs.

11-13

erucosa, 1599

Siphocampium sp., 1600

Siphonosphaera (?), 1586; PI. 1C, figs. 3, 4 spp., Pl. 1C, figs. 1, 2; PI. 2B, fig. 5

Solenosphaera, 1586 omnitubus, 1586; Pl. 1A, figs. 23, 24; Pl. 4, figs. 1, $2 ; 1534 ; 1542 ; 1550 ; 1554 ; 1558 ; 1562 ; 1563$; $1580 ; 1579$

spp., Pl. 1A, figs. 12-22; PI. 2A, figs. 4-10
Spirocyrtis, 1601

scalaris, $1586 ; 1599 ; 1601$; PI. 1G, figs. 25-27;

$1538 ; 1546 ; 1552 ; 1556 ; 1560 ; 1563 ; 1579 ; 1584$ sp. aff. $S$. scalaris, PI. 1G, figs. 19-24; Pl. 2H, figs. 15-18; Pl. 3E, fig. 2

Spongaster, 1586; 1589

(?), Pl. 1D, figs. 11, 12

klingi, 1589; Pl.1D, figs. 8-10; Pl. 4, figs. 7, 8; 1534;

$1542 ; 1550 ; 1554 ; 1558 ; 1562 ; 1563 ; 1580 ; 1579$

pentas, 1589; Pl. 1D, figs. 5-7; 1534; 1542; 1550; $1554 ; 1558 ; 1562 ; 1579$

tetras, 1589; P1. 1D, figs. 2-4; 1534; 1542; 1550; $1554 ; 1558 ; 1562 ; 1579$

tetras irregularis, 1589

Stichocorys, 1594; 1595

armata, 1595; Pl. 2E, figs. 13-15; 1532; 1538; 1546; $1552 ; 1556 ; 1560 ; 1564 ; 1568 ; 1549 ; 1580 ; 1577$; 1584

delmontensis, 1595; Pl. 1F, figs. 5-7; Pl. 2E, figs. $10-11 ; 1538 ; 1546 ; 1552 ; 1556 ; 1560 ; 1563 ; 1568$; $1549 ; 1580 ; 1577 ; 1584$

diploconus, 1582; 1595; P1. 2E, fig. 16; 1532; 1538; $1546 ; 1552 ; 1556 ; 1560 ; 1566 ; 1567 ; 1549 ; 1577$; 1584

peregrina, 1582; 1595; Pl. 1F, figs. 2-4; Pl. 8. fig. 5; $1538 ; 1546 ; 1552 ; 1556 ; 1560 ; 1562 ; 1563 ; 1580$; $1579 ; 1584$

wolffii, 1595; Pl. 2E, figs. 8, 9; 1532; 1538; 1546; $1552 ; 1556 ; 1560 ; 1564 ; 1567 ; 1549 ; 1580 ; 1577$; 1584

Theocampe, $1500 ; 1601$ armadillo group, 1601; PI. 3F, figs. 3-6; 1552-1556; $1560 ; 1570 ; 1573 ; 1574$

mongolfieri, 1601; Pl. 3E, fig. 13; 1552; 1560; $1571 ; 1574 ; 1582 ; 1585$

pirum, 1601; Pl. 3E, figs. 10, 11; 1552; 1556; 1560; $1570 ; 1571 ; 1549 ; 1575$

Theocorys anapographa, 1596; 1583

ovata, 1601

spongoconum, 1596; Pl. 2F, fig. 4; Pl. 3C, fig. 3; $1538 ; 1546 ; 1552 ; 1556 ; 1560 ; 1567 ; 1571 ; 1549$; 1575

sp. (?), Pl. 2F, fig. 3

Theocotyle, 1596 cryptocephala (?) nigriniae, 1596; 1585

ficus, $1596 ; 1538 ; 1552 ; 1556 ; 1560 ; 1573 ; 1574$

venezuelensis, 1596; 1595

Theocyrtis, 1598 annosa, 1598; Pl. 2H, fig. 4; Pl. 3D, figs. 12, 13; $1538 ; 1546 ; 1552 ; 1556 ; 1560 ; 1568 ; 1570 ; 1549$; $1576 ; 1584$

tuberosa, 1598; Pl. 3D, figs. 14, 15; 1538; 1546; $1552 ; 1556 ; 1560 ; 1570 ; 1571 ; 1549 ; 1575$ sp. aff. $T$. tuberosa, Pl. 3D, figs. 16-18

Tholospyris, 1591

Thyrsocyrtis, 1596 bromia, 1596; Pl. 8, fig. 6; 1546; 1552; 1556; 1560; $1571 ; 1572 ; 1575$ 
hirsuta hirsuta, 1596, 1533, 1585

jacchia, 1595

rhizodon, 1596; Pl. 3C, fig. 6; 1538; 1546; 1552; $1556 ; 1560 ; 1572 ; 1574$

tetracantha, 1596; 1538; 1546; 1552; 1556; 1560; $1571 ; 1573 ; 1575 ; 1583 ; 1585$

triacantha, 1596; Pl. 3C, fig. 7; 1538; 1546; 1552;

$1556 ; 1560 ; 1572 ; 1574 ; 1583 ; 1585$

Tribonosphaera, 1586

sp., Pl. 2B, figs. 6-8

Tricolocampe cylindrica, 1600 polyzone, 1601

sampedroana, 1600

stenozona, 1601

Trigonactura angusta, 1588

Trigonastrum, 1589 gegenbauri, 1589 regulare, 1589

Trissocyclus stauroporus, 1590

Tristylospyris, 1592 triceros, 1586; 1590; 1592; PI. 3A, figs. 11, 12; $1534 ; 1542 ; 1550 ; 1554 ; 1558 ; 1570 ; 1572 ; 1575$ 